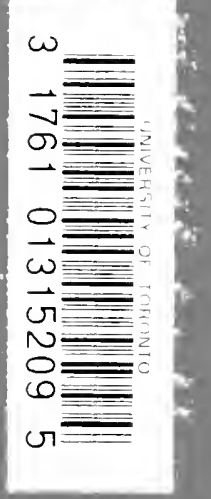

릉 $\checkmark \equiv$ 
Digitized by the Internet Archive in 2007 with funding from Microsoft Corporation 
, 



$$
.438
$$$$
T
$$ 



\section{THE PURITAN}

IN

ENGLAND AND NEW ENGLAND. 



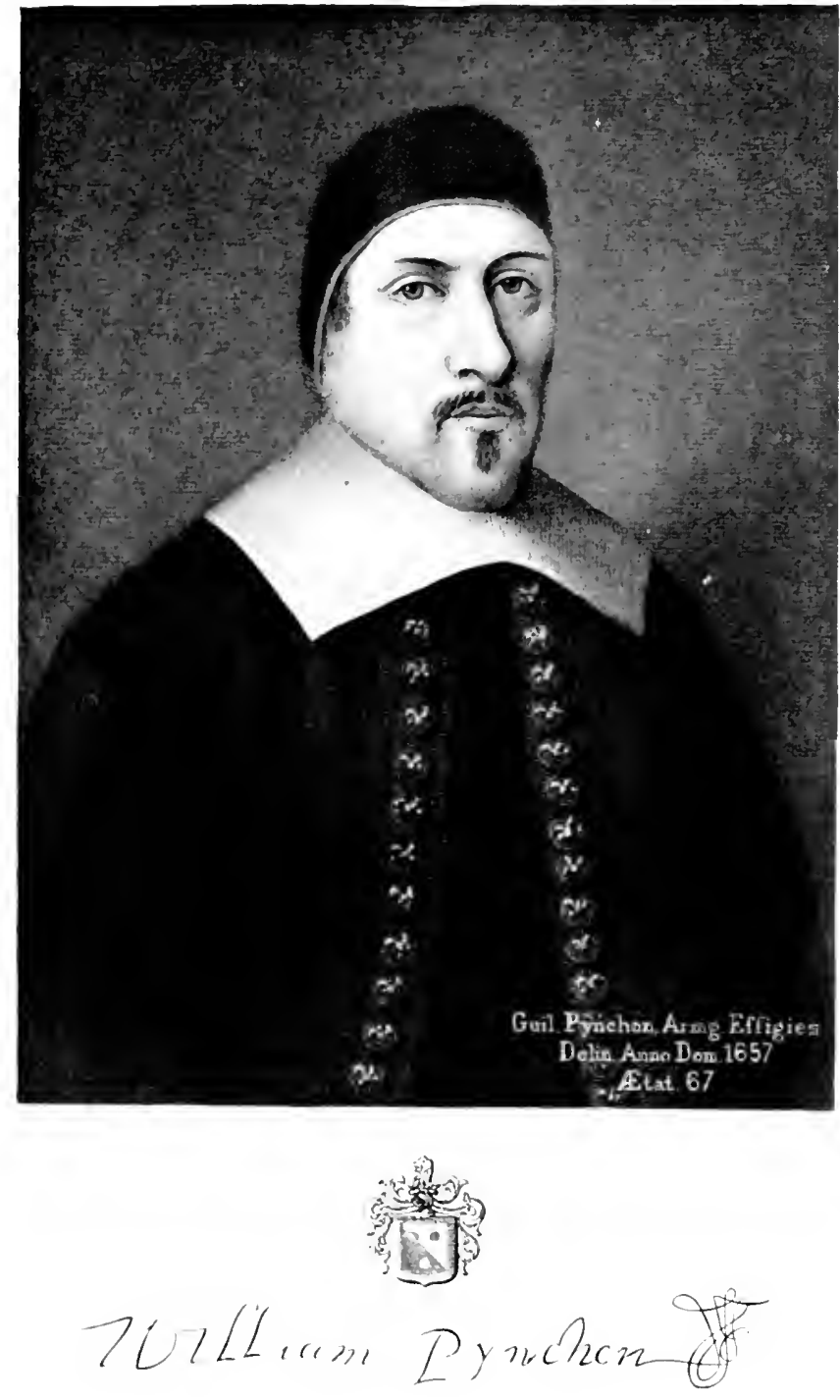


\title{
THE PURITAN
}

IN

\section{ENGLAND AND NEW ENGLAND.}

BY

EZRA HOYT BYINGTON, D.D.

MEMBER OF THE AMERICAN SOCIETY OF CHURCH HISTORY.

\author{
đaitb an $\mathbb{3}$ ntraduction \\ $\mathrm{BY}$ \\ ALEXANDER MCKENZIE, D.D. \\ MINISTER OF THE FIRST CHURCH IN CAMBRIDGE.
}

BOSTON:

ROBERTS BROTHERS.

I 896. 
Copyright, 1896 ,

By Ezra H. Byington.

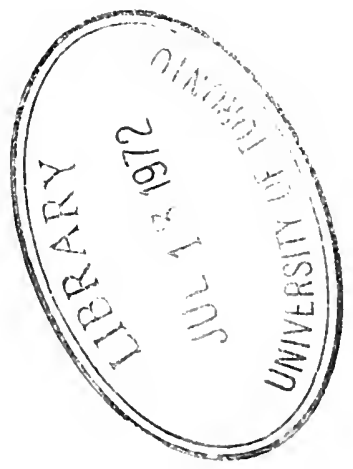

Intibersity 引ress:

John Wilson and Son, Cambridge, U.S.A. 


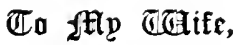 \\ WHOSE INSIGHT AND LITERARY TASTE \\ HAVE BEEN MY CONSTANT RELIANCE IN THE PREPARATION \\ OF THESE CHAPTERS, \\ AND WHOSE EFFICIENT HELP \\ HAS LIGHTENED THE LABOR OF CARRYING THEM TIHOUGH \\ THE PRESS, \\ THEY ARE NOW DEDICATED.
}


Y 


\section{Preface.}

THIS book has had a natural growth. It had its 1 origin in a paper, which I read before one of our historical societies, on William Pynchon, a Puritan, who came to New England in 1630, and who published a book, some twenty years later, which was much talked about. In preparing that paper I found it necessary to read the works of Mr. Pynchon, and the replies to them. The discussions relating to those volumes were found to be connected with the progress of opinion in England, and with the history of the IVestminster Assembly. It was only by tracing the history to its sources, that I was able to gain an adequate knowledge of the opinions and the influence of that leading Puritan.

As other historical papers have been called for, from time to time, I have followed the same topical method, because I found it the most fruitful method in the study of New England history. One topic led naturally to another, so that I have prepared papers on The Origin and Development of Puritanism in England; The Two Earliest Colonies in New England; The Social and Family Life of the Pilgrims and Puritans; Their Min- 
isters and Modes of Worship; Their Religious Opinions; and The Working of the Union of Church and State, in their Second Century. The fathers of New England have left a large number of journals, and narratives, and histories, with many theological treatises, and discussions, and pamphlets. The literature which has come down from the English Puritans is also abundant. So that there is no lack of fresh materials for the historical student. No other pioneers, of whom I have any knowledge, have left materials so rich and abundant, for those who would study their history. One needs to get their point of view, if he would do justice to them, and he can get their point of view only through their writings.

Two of these papers were published, some time ago, in the "Andover Review." Others have been read before a number of historical societies, and before students, in colleges and seminaries. They have all been rewritten, and reconstructed, so as to bring them into connection with each other. New topics have been introduced, with the purpose of covering, so far as practicable, within our limits of space, the whole field of the history of our forefathers.

I am under great obligations to a number of recent anthors, who have cast new light upon the history of the Puritans. John Richard Green, in his "History of the English People," has shown the origin and the meaning of Puritanism, better than any of the earlier English historians. Douglass Campbell, in his two volumes on "The Puritan in Holland, England, and America," has 
proved that the influences which moulded the Puritan party came, not only from England, but from the Dutch Republic, and from the other Protestant nations on the continent. One needs to correct some of his extreme statements by referring to Macaulay, and especially to Motley; but, rightly used, his work is of great value. Dr. Henry M. Dexter, in his monumental work on "Congregationalism as seen in its Literature," has uncovered the abundant materials for the history of our fathers, and has shown us how to use them. And not to mention other recent volumes of great value Professor Williston Walker, in his book on "The Creeds and Platforms of Congregationalism," has made a rich and original contribution to our history.

This book, in its present form, is offered to the public, in the hope that it may contribute toward a fuller knowledge and appreciation of our forefathers, who, under the limitations of a pioneer life, in the seventeenth century, laid the foundations of this free and progressive nation.

EzRa Hoyt Byington.

Franklin Street, Newton, Mass.

March 31, 1896. 


\section{Contents.}

PAGE

I. List of AUthorities REFERRED to . . . . . xxv

II. Some Important Dates in Puritan History . xxxi

III. Introduction, by Alexander Mckexzie, D.D. xxxv

I.

THE PURITAN IN ENGLAND.

Estimate of the Puritans by Macaulay; Hallam; Hume; Carlyle.Numbers who came to New England.

I. Our forefathers to be understood by the history of the struggle in England. - Beginnings of the Reformation with Wyclif. - Translation of the Bible. - Lollards . . . . . . . . . . . . . 5

II. English reformation under Henry VIII.; political, - Growth of principles of the Reformation . . .

III. Prayer Book of Edward VI. - Queen Mary's persecution . . . . . . . . . . . . . . I I

IV. Elizabeth: a Protestant Queen; her Moderation; acts of Supremacy, and of Uniformity. - Rise of the Puritan Party; grounds of dissent, not doctrines but forms and vestments . . . . . . . 12

V. Mildness of the Church in the early years of the Queen. - Court of High Commission. - The religio purissima. - The London ministers silenced; severe penalties. - Patience of the Puritans. Whitgift becomes Archbishop, $\mathrm{I}_{5} 8_{3}$. . . . . I6

VI. Success of the Archbishop. - Censorship of the press. - The Bible read by the People . . . 20 
VII. The Separatists. - Robert Browne; his principles. - Persecution of the Brownists. - Martyrdom of Barrowe; Greenwood; Penry . . . . . .

VIII. The Martin-Mar-prelate tracts; humor. - Influence of the tracts; replies to them . . . . . . .

- IX. Growth of Puritanism; causes of growth. - Weakness of Protestantism in Europe; its perils at that time. . . . . . . . . . . . .

X. James the First. - Millenary petition. - Hampton Court Conference; rejection by the King and the Prelates

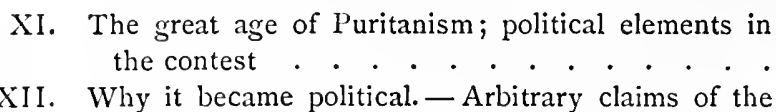

XI. The great age of Puritanism; political elements in
the contest - . - . . . . . . -
XII. Why it became political. - Arbitrary claims of the King advocated by the Prelates. - Character of James. - New Claims for Episcopacy. - Laud. Calvinism. - Love of Freedom . . . . . . .

XIII. First Parliament. - The King levies customs and taxes. - The Puritans have a majority of the Commons; demand redress of grievances: Pym; Eliot; Wentworth; Coke; Archbishop Abbott . . . .

XIV. The Pilgrim Fathers. - The Thirty Years War. The French alliance . . . . . . . . .

XV. The Pilgrims from North England, Gainsborough, and Scrooby. - The old Manor House. - Persecution of the people; their condition and spirit; escape to Holland; Amsterdam; Leyden; their employments; reasons for another removal; voyage to Plymouth . . . . . . . . . . . . .

XVI. Charles the First. - Laud. - Tendencies toward Rome. - Parliament. - No grants of money without redress of grievances. - Petition of Right. Puritans stand for the people. - Tyranny of Charles. - Iaud becomes Archbishop. - Observance of Sunday. - Milton's Lycidas . . . . 58

XVII. Causes of the so-called narrowness of the Puritans . 68 XVIII. The Puritan migration: despair of good government at home; early settlements in New England . 
XIX. The Political struggle in England. - Ship-money. -

Hampden's great trial. - The Scottish War. - The Short Parliament. - Long Parliament. - Wentworth and Laud in the Tower. - Death of Pym and Hampden; mistakes of their successors; failure of the effort to abolish the Monarchy and the Established Church; reasons for the failure . 72

XX. Final estimate of the Puritans; their limitations. The Age. - The Puritans compared with the Dutch; their merits; defenders of liberty; their culture and manners : Lord Essex; John Milton ; Hutchinson; Winthrop. - The Puritan ministers. - Puritan homes. - Settlement of Massachusetts in the best age of Puritanism . . . . . . 76

\section{II.}

\section{THE PILGRIM AND THE PURITAN: WHICH?}

The Province of Massachusetts of 169 I included two colonies, - the old Colony of Plymouth and that of Massachusetts Bay. - Which had most to do in moulding the people of New England?

I. Earlier historians of New England gave the precedence to the Puritans; later writers to the Pilgrims . . . 85

II. The Old Colony founded I620; the Puritan Colony I628 . . . . . . . . . . . . . . . . 86

III. The Pilgrims Separatists; Puritans Non-Conformists. - Winthrop's greeting to the Church of England . $\delta_{7}$

IV. The Pilgrims from humble stations in life; their occupations. - The Puritans from upper middle classes

V. The Pilgrims were already exiles, and came to find a place of refuge. - The Puritans came to found a NEw England, where they could enjoy liberty in Church and State . . . . . . . . . .

VI. The Pilgrims first on the ground; had already framed their institutions; the democratic state; the free Church. - The Puritans were guided by their example. - Dr. Samuel Fuller 
VII. The Puritans moulded the social institutions of the Colonies. - Influence of Holland. - Aristocracy in Massachusetts. - Union of Church and State . . 98

VIII. The Puritans richer and more numerous; and more enterprising; vigorous growth of their Colony . . IOI

IX. The Puritans the intellectual leaders; their Ministers compared with those of the Pilgrims. - Harvard College. - The literature from the Puritans. . . I03

X. The Puritans the leaders in New England Confederacy. - The Cambridge Platform . . . . . 107

XI. In respect to Legislation, both Colonies made laws too severe; both used cruel punishments; both punished Quakers and Witches. - The Pilgrims were more merciful and just in the execution of the laws . . 109

XII. Conclusion. - The Pilgrims were gentle; tolerant; merciful. - The Puritans more vigorous; enterprising; powerful . . . . . . . . . .

\section{III.}

\section{THE EARLY MINISTERS OF NEW ENGLAND.}

The Puritan ministers the best representatives of the Puritans.

I. In sympathy with the Puritan spirit; had been moulded by persecution; their courage; their opportunities. I I 8

II. They were men of education and culture; graduates from the great universities; had been ministers in the Church of England; their knowledge of the classics; of literature; of the original languages of the Bible; their large libraries . . . . . . . I20

III. Their dignity of character and their manners; wore the gown and bands in the pulpit; their general refinement ; Mrs. Stowe's sketch of their manners : Parson Lothrop ; Dr. Samuel Hopkins . . . . . . I25

IV. Support of the ministers voluntary in Boston; a tax by authority of law elsewhere; salary and "settlement;" amount of the salary; how collected; the 
ministers farmers; President Edwards' cows ; ministerial hospitality in the olden time . . . . . 130

V. Dwellings of the ministers; furniture; dress; food; log-houses; the old well-sweep; thatched roofs; house of Mr. Whitfield in Guilford, Conn.; pewter platters; no forks; not much butcher's meat; fish and game; rye and Indian bread; hasty pudding; little tea, and no coffee; beer and cider; wine and spirits ; no drunkenness . . . . . . . . . 135

VI. The early meeting-house the central building in the town : the pulpit; sounding-board, benches, gallery; log meeting-houses; frame buildings; pointed roof with belfry in the centre; Hingham meeting-house now in use; origin of the Puritan church architecture ; origin of "pews;" "dignifying" the seats ; third style of New England meeting-house; Old South Church in Boston; meeting-houses never lighted except by the sun; objections to candles as tending to Popery; no means of warming in winter . I 39

VII. Methods of public worship : laws required attendance; smoking within two miles forbidden; Saturday night; morning service at nine o'clock ; summoned by beating of the drum; the pulpit with the two ministers; seats for ruling elders and deacons; order of services ; requests for prayer; opening prayer; exposition of the chapter; singing by the congregation; the tunes used; hymn-books ; no instrumental music; style of church music. - Music taught in Harvard College. - Decline of music in the second and third generations. - The infuence of the ministers in the revival of music. - Singing by " note or by rote." - Style of preaching. - Length of sermons; the hour-glass ; subjects. - Origin of written sermons. - The administration of the Sacraments. - The contributions. - Church business, and dismission "before the setting of the sun" . . . . I47

VIII. Mid-week lectures; habits of the people in attending them.- Lectures of John Cotton and John Norton, 
"Milk for Babes." - Religious instruction of the young. - Visiting the sick. - Pastoral work . . . 156

1X. The churches which they founded: the first church at Plymouth; at Salem; at Boston. - Officers; ordination; pastor and teacher; ruling elders; deacons. A minister limited to his parish . . . . . . . 158

X. Mistakes of the Puritan ministers. - Readiness to correct errors. - Changes they adopted in the reading of the Scriptures; in their religious services; changes in respect to funerals; changes in the celebration of marriage; changes from the use of numerals for the months and days of the week. - Fast Day and Thanksgiving for Good-Friday and Christmas . . I62

XI. Their progressive spirit. - The suffrage limited by a religious test. - Connecticut Colony without such a test. - The test removed in Massachusetts. No religious test at Plymouth. - Case of Roger Williams: his arrival in the Colony; preaching in Salem; in Plymouth; in Salem again; denounces the churches, and the charter; banished by the General Court; real reasons for the sentence; the sentence revoked . . . . . . . . . . . . . 168

XII. The persecution of the Quakers a great blot upon the good name of the Puritans; less severe than in England; the good sense of the people arrested it in the course of a few years. - The Quakers punished for disorder, not for their religion. - The delusion in respect to witchcraft thirty years later, the worst thing in their history, but soon over. - Origin of the delusion in New England; in Old England; in Germany. - Part which ministers had in it; the ministers the first to discover the sin and folly of putting to death those suspected of witchcraft . . . . . I74

XIII. The government of their churches: independent at first; the need of fellowship; Synod at Cambridge ; Cambridge Platform; Plan for Ecclesiastical Councils; their powers; influence of the Platform . . . I77

XIV. The right of private judgment; the spirit of inquiry; independence of the Puritans . . . . . . I8I 
IV.

WILLIAM PYNCHON, GENT.

The leaders among the Puritans: Winthrop, Dudley, Endicott, Sir Henry Vane, Governor Bradford, Brewster, Winslow.

I. William Pynchon; less known than the others. - The Pynchon family came to England with William the Conqueror; a wealthy and honorable family for six hundred years. - W. Pynchon came to Massachusetts with Governor Winthrop in 1630 ; member of the Board of Assistants of the Colony for twenty years ; a man of business; a fur-trader of great wealth; founder of the first church in Roxbury . . . . . 186

II. Settlement of Springfield: reasons for it; the pioneers go in 1635 .

III. Pynchon and his company. - Agawam. - Plan of the village. - A minister secured. - Settlements in Connecticut . . . . . . . . . . . . . 19r

IV. A new government: Pynchon the magistrate. Records of his court. - A case of witchcraft. Municipal regulations. - Dealings with the Indians. - The Bay Path . . . . . . . . . . . . 195

V. Mr. Pynchon's book: its subject; protest of the General Court; the book burned; its author summoned to retract; Mr. Norton appointed to reply to the book; causes of the commotion . . . . . . . 200

VI. Analysis of the argument; remarkable learning which it displays ; discussion of Hebrew and Greek texts; quotes Augustine to prove that Christ died a voluntary death . . . . . . . . . . . . . 204

VII. John Norton of Ipswich; his learned reply. - Mr. Pynchon's answer to the Court . . . . . . . 208

VIII. Pynchon is placed under bonds; retires from Massachusetts and settles in England; defended by Sir Henry Vane . . . . . . . . . . . . . 210

IX. Mr. Pynchon in England: list of his theological works; incidents of his closing years; death in Wraysbury near Windsor Castle; result of his theological discussions in New England . . . . 214 
V.

THE FAMILY AND SOCIAL LIFE OF THE PURITANS.

Home the creation of the Puritan; reasons why.

I. Illustrations of Puritan life: Mrs. Hutchinson's life PAGE of her husband, Col. Hutchinson; his delicate physical organization; love of nature, of music, and fine art; his conjugal affection; his love of the military art; services during the Civil War; imprisonment and death. - John Milton : tract on Education; love of beauty; the model Puritan. - A Puritan Mother 222

II. Letters of Governor Winthrop and his wife; his personal history ; Margaret Tyndal, his third wife; letter from his father; Winthrop's letters; replies from Mrs. Winthrop; voyage of Mrs. Winthrop to New England; reception by the people; spirit of all these letters

III. Numerous Journals of the Pilorims; and Puritans 232

IV. Characteristics of their life ; influences from the seventeenth century; belief in Witchcraft; cruel punishments in England

V. The Colony at Plymouth: they were pioneers; rough life in the new country; struggles for a bare subsistence; danger from the Indians

VI. The Massachusetts Colony; sufferings of the early years. - Rhode Island. - Connecticut. - New Hampshire. - The first wind-mill in Boston. - The first water-mill. - Modes of travelling . . . . . 239

VII. The Courtship of Miles Standish, a picture of life at Plymouth in I624; Priscilla Mullins ; Standish; John Alden; the marriage; the company gathered at the marriage . . . . . . . . . . . . . . 242

VIII. Common schools for the people at Plymouth; Massachusetts; Connecticut. - Salaries of the first schoolmasters

IX. Legislation as affecting social life. - The Blue Laws, 247 invention of Samuel Peters; sumptuary laws; the 
laws milder than those in New York, or Virginia, or England; number of capital crimes; laws against Quakers; soon repealed; juries refuse to convict of witchcraft after 1692. - Body of Liberties. Tendency of Legislation to Democracy . . . . 251

X.) Meaning of the prefix Mr., Goodman, Goodwife. $-A$ thief lost the title of Mr. . . . . . . . . 256

XI. Dress in the Colonial Period. - The Simple Cobbler of Agawam complains of extravagance. - Laws to prohibit extravagance. - Inventory of the clothing of Elder Brewster . . . . . . . . . . . . 258

XII. Domestic furniture. - Inventory of Governor WVinthrop's furniture. - That of Martha Coytmore . . 260

XIII. Amusements. - The Puritans enjoyed their religion.- Loved the new country. - A hearty social life. The first Harvest Festival at Plymouth ; not religious. - Training days. - Judge Sewall's dinner parties. - "Mixt dances and unlawful gaming" of the young people . . . . . . . . . . . . . 262

XIV. Intercourse with the French Catholics. - La Tour and the learned Friar; entertained by Governor Winthrop. - The Sunday dinner at the Governor's. The Jesuit Missionary, Druillette. - His visit to the Apostle Eliot; they discourse concerning their work for the Indians. - Governor Bradford provides a "fish dinner" on Friday for the Jesuit . 265

XV. Results of Puritan training upon the eighth generation. - English families decay after a few generations. - The Puritan type persistent. - Ancestors of Ralph Waldo Emerson; of President Adams; Hawthorne ; Longfellow; James Russell Lowell. Members of the New England Historic Genealogical Society who have died within three years, a majority of Puritan descent. such as Phillips Brooks, Francis Parkman, Judge Aldrich, Leverett Saltonstall, Dr. A. P. Peabody, Dr. A. A. Miner, and Robert C. Winthrop 


\section{VI.}

RELIGIOUS OPINIONS OF THE FATHERS OF NEW ENGLAND.

I. The Puritans first of all, Protestants; appealed to the Bible ; justification by faith; sanctity of the Lord'sday. - Sermons of a theological character . . . 282

II. Reformed branch of the Protestant Church; Calvinists ; Exalted the Sovereignty of God . . . . 284

III. Their interest at first in Church polity. - Why? . . 285

IV. Later, their interest in doctrine. - The first Catechisms, - Strongly Calvinistic. - Candidates for Church membership required to state their views in theology. - Church Creeds. - The first Synod, 1637. - Mr. Pynchon's book . . . . . . . . . . . 286

V. The Cambridge Synod; recommends the Westminster Confession

VI. Thomas Shepard : life in England; escapes in disguise to America ; pastor at Cambridge. - He teaches the decrees : freedom of the will; the fall; imputation; limited atonement; faith the gift of God . . . . 292

VII. John Norton: "The Orthodox Evangelist;" decrees; freedom; unity of the race: grace of God; parable of the Prodigal Son; saving faith; justification. Thomas Hooker: the great preacher, and practical theologian; a free will; inability to good; power of the Holy Spirit; motives to repentance . . . . 295

VIII. Willard's Body of Divinity : election and reprobation; all mankind sinned in Adam; the Person of Christ; satisfaction of God's justice; inability to good; passive regeneration; the work of the Spirit . . . 302

IX. The Half-IVay Covenant; Synod of I 662 accepts the new departure; opposition to the decision; effect upon the churches. - Decline of piety. - Trust in ordinances and forms. - Spread of Arminianism

$\mathrm{X}$. The Reforming Synod: its statements in respect to the decline of morality and religion; appeal for a reformation; seconded by the General Court . . 314 
of the Savoy Confession; its present author- PAGE ity. - Council of 1865 . . . . . . . . . . 319

XII. Practical results of the older Calvinism; a remarkable type of religious character. - A democratic tendency.

- Transmission of a vigorous type of manhood . . 32I

XIII. Other results of High Calvinism: small number in the Churches; comparison with the present time . . 324 XIV. Declension of the Puritan Churches. - Statements of Thomas Prince; Whitefield; the younger Edwards. - Spread of Arminianism . . . . . . . . . 326

XV. The Edwardean theology: a new style of preaching; revivals of religion; missionary enterprises. - The New England theology . . . . . . . . 330

\section{VII.}

THE CASE OF REVEREND ROBERT BRECK, OF SPRINGFIELD.

The beginning of the second century in New England a period of transition. The study of a single life of a past generation shows us the manners, opinions, and institutions of the people.

I. Springfield one hundred and sixty years ago. - Prosperity of the Connecticut Valley . . . . . . . 337

II. Church and State. - Four qualities required of ministers. - Methods of calling and settling pastors . $.33 \mathrm{~S}$

III. Robert Breck in early life; in college : as a candidate for the ministry; called to Springfield; opposition of the neighboring pastors . . . . . . . . 342

IV. Replies to the charges. - Asks to be judged by his sermons, not by reports. - Declines the call . . . 345

V. The people not satisfied. - The ministers advise against renewing the call. - Mr. Breck returns, and attempts to adjust the difficulties . . . . . . . 348

VI. The Church renews the call. - Mr. Breck goes to Boston for advice; is examined and approved in Boston ; and accepts the call . . . . . . . 350 
VII. A Council called for his ordination. - Doubts about its legality. - Judges summoned to Springfield . 352

VIII. Meeting of the Council; a remonstrance presented; evidence in support of the remonstrance; the proceedings interrupted by the arrest of Mr. Breck, who was taken from the Council to the Court House; he is sent into Connecticut, gives bail, and returns to Springfield; the Council completes the examination and adjourns . . . . . . . . . . 356

IX. The case brought before the General Court, which decides that the Council is a legal Council. - The Council again meets and ordains Mr. Breck . . . 362

X. Efforts to secure judicial action to remove Mr. Breck . 364 XI. Work of the young minister; growth of the Church; forty-eight years of usefulness; testimony of his associates

\section{VIII.}

THE RELIGIOUS LIFE IN THE EIGHTEENTH CENTURY IN NORTHERN NEW ENGLAND.

Brunswick, Maine.

Northern New England settled in the eighteenth century. - Difference between the older and the newer churches.

I. First preaching in Brunswick: the first meeting-house; its environment . . . . . . . . . . . 373

II. The first ministers : Rutherford; Dunlap; Miller . 374

III. Records of the Parish . . . . . . . . . . . 375

IV. The connection of Church and State; reasons why it was unfavorable to the Church . . . . . 376

V. Differences among the people in regard to Church government: Congregationalism vs. Presbyterianism. The east end $v s$. the west end of the town. - The Lord's Supper; how administered. - Baptism. The style of church music . . . . . . 378 
VI. Habits of the people: all went on foot to the church; the saddle and pillion; no stoves in the meetinghouses; tunes used in the choir; hymn-books . . 380

VII. The ministers of those days. - Samuel Eaton. - Genuine manhood. - Use of liquors . . . . . . . $3 \mathrm{~S}_{\mathrm{I}}$

VIII. Religious teachings : instruction of children . . . $\cdot 3^{8} 3$

IX. Methods of pastoral visiting. - Journal of an old minister. - Revivals of religion . . . . . . . 384

$\mathrm{X}$. Permanent qualities of their religious life. - Relation of that century to the nineteenth . . . . . 386

INDEX . . . . . . . . . . . . . . . • . • 39I 
. 


\section{List of Authorities Referred to.}

Adays, Charles Fraxcis. Three Episodes of Massachuset:s History: Boston. ISgz.

Answorth, H. The Book of Psalmes, Englished. both in prose and metre. Amsterdam. I6I2. Amoxg M Books. James Russell Lowell.

BAcox. Leorard. Genesis of the New England Churches. Is-7. Bacox. Lord. Works. Montagu Edn.

BAxcroft's History of the United States. 6 vols. Isjó.

Bay Psaly Book. Cambridge. I6 40.

Bibliotheca SACRA. 5I rols. Isff-ISo5.

Bliss. George. Historical Address. Springfie!d. ISzS.

BLte Laws: False and True. I. Hammond Trumbull. is-ó.

Bostox News Letren, published from. I

Bostox, Memorial History of. 4 rols.

Bowdors College. History of.

BRAdFord. W. History of Plymouth Flantation. Frinted from the Original Manuscript. for the Mass. Hist. Soc. I\$ 66.

Browse, Robert. A treatise of reformation without Tarrying for Anie. 1552 .

BRUNSWICK. History of. ISjS.

Cambridge Platform of Chlthch Disciplise. igas.

Campbell. Dotglass. The Puritan in Holland. England. and America. 2 vols. ISgz.

CAxie. J. Necessitie of Separation from the Church of England. 1634 .

Cosgregatioxal Qt*arterly. 20 vols. IS;9-is/S. Boston. Cosiecticti Valley, History of the. 
Contemporary Review. is 82.

Cotton, John. The Keyes of the Kingdom of Heaven and Power thereof; according to the Word of God. London. $16+1$.

Cotron, John. The Way of the Churches of New England. 1645.

Cotton, John. Milk for Babes.

Courtship of Miles Standish. Boston. 1859 .

Cumberland Association. Centenujal Pamphlet. iSgr.

Dexter, Henry M. Congregationalism as seen in its Literature. ISSO.

Dexter, Henry M. As to Roger Williams. I876.

Dexter, Morton. The Story of the Pilgrims. IS94.

Dunning, A. E. Congregationalists in America. 1894 .

Dwight, Sereno E. Life of President Edwards.

Edwards, Jonathan, President. Inquiry Concerning Qualifications for Full Communion.

Edwards, Jonathan, D.D. Works.

Election Sermons. Massachusetts. 1668-1669-1670.

Ellis. The Puritan Age and Rule.

Encyclopedia Britannica. 9th ed. Articles on Education;

Quakers; and Witchcraft.

Felt, J. B. The Ecclesiastical History of New England. 2 vols. Boston. I 862 .

Fisher, George E., Professor. History of the Christian Church. I 887 .

Fiske, John. The Beginnings of New England. I $\$ 90$.

Foxe, John. The Book of Martyrs.

Froude, James Anthony. History of England from the Fall of

Cardinal Wolsey to the Defeat of the Spanish Armada. 12 vols.

Gardiner, S. R. History of England from the Accession of James I.

General History of Connecticut. Rev. Samuel Peters. I78i. General Laws of Massachusetts.

Goodwin, Joirn A. The Pilgrim Republic. ISSS.

Green, J. R. History of the English People. 4 vols. 1878.

Greenleaf's, Ecclesiastical Sketches.

Hallam, Henry. The Constitutional History of England. HARLow's Address at Cape Elizabeth. 
Hereditary Genius. Galton.

Hill, Hamilton A. History of the Old South Church. Boston. 2 vois. I 888.

Holland, Dr. J. G. History of Western Massachusetts.

Hood's Music in New England.

Hooker, Thomas. The Soul's Vocation. 1638.

Hooker, Thomas. A Survey of the Summe of Church-Discipline. 1648.

Hooker, Thomas. The Saints Dignitie and Dutie.

Hooker, Thomas. The Unbeliever's Preparing for Christ.

Hooker, Richard. The Laws of Ecclesiastical Polity.

JEFFERSON'S Notes in Virginia.

Johnson, Edward. The Wonder-Working Providence of Sion's

Saviour. 1654 .

LECHFORD, T. Plain Dealing. I642.

Life of Colonel Hutchinson. By his widow.

LONGFELlow, H. W., Life and Letters of. 2 vols.

Macaulay, T. B. History of England. 4 vols.

Martin-Mar-Prelate; Tracts. I 588-89.

Massachusetts Historical Society's Collections.

Mather, Richard. Church Government and Church Covenant discussed. 1643 .

Mather, Cotton. Ratio Disciplinæ Fratrum Nov-Anglorum. 1726.

Mather, Cotton. Magnalia Christi Americana. 1702.

Milton, John. Lycidas.

Minister's Woolng. Mrs. H. B. Stowe.

Morris, Henry. History of the First Church in Springfield,

Mass. I875.

Morton, Nathaniel. New England Memorial.

Motley. United Netherlands.

MOURT's Relation; or Journal of the Plantation at Plymouth. 1865. Edited by Dr. H. M. Dexter.

Narrative of the Proceedings of the Ministers of HampShire County. Answer to the same. Letter to the Author of the Answer. Three Pamphlets. Boston. I736-37.

National Congregational Council, Debates and Proceedings. I 865 .

Neal, S. D. History of the Puritans. 4 vols. 1732. 
New England's First Fruits. London. I643.

New England Historical and Genealogical Register.

New England Primmer.

Norton, John. A Discussion of the Sufferings of Christ. Reply to Pynchon. I653.

Norton, John. The Orthodox Evangelist. I654.

Old Town Folks. Mrs. H. B. Stowe.

PAlfrey, J. G. History of New England. 5 vols.

Porter, NoAh. New England Meeting-Houses. Article in New Englander. I 883 .

Prince, Thomas. A Chronological History of New England in the Form of Annals. I 736.

Province Laws. Massachusetts. Vols. I.-III.

Puritanism in the Old World and in the New. Rev. J.

Gregory. New York. I 896.

Pynchon, Willialy. The Meritorious Price of our Redemption, Justification, etc. 1650 .

Pynchon, William. Manuscript Records. Springfield City

Library.

Ravenscroft. The Psalter. I62I.

Records of the Church in Roxbury. Record Commissioners report. Roxbury. 6.1880.

Records of the Colony of Connecticut.

Records of the Colony of Massachusetts.

Records of the Colony of Plymouth.

Results of THE Synods of I662 AND I669, in the Magnalia.

Robinson, John. Works. 3 vols. I 85 I.

SCARLET LetTer. Nathaniel Hawthorne.

Sewall, Samuel, Diary of, I674-I729. Mass. Hist. Society

Publications, 2 vols.

Shepard, Thomas. Works. 3 vols. 1855 .

Simple Cobbler of Agawam. Nathaniel Ward. 1647.

Sone Old Puritan Love-Letters. Twichell. I $\$ 93$.

Sprague, William B. Annals of the American Pulpit. Vols. I.-II. Stoddard, S. An Appeal to the Learned. I 709.

Strype, J. Workes. [Whitgift.]

Tarbox, Increase N. Art. on the Pilgrims. Collections of the Old Colony Hist. Soc.

The Pilgrim Fathers. Rev. John Brown. New York. I895. 
Tracy, Joseph. The Great Awakening. I 8 fI. Twichell, Joseph H. John Winthrop. I $\$ 92$. Waddington, J. Congregational Martyrs. I86I . Walker, Williston. Creeds and Platforms of Congregationalism. 1893.

Walker, Williston. A History of the Congregational Churches. 1894.

Westainster Confession of Faith, and Catechisus.

Whitefield, George. Journals, and Life.

Willard, Samuel. A Compleat Body of Divinity. 1726.

Winslow, E. Brief Narration. I622.

Winthrop, JohN. Journal of Transactions in the Settlement of Massachusetts. I790.

Winthrop, R. C. Life and Letters of John Winthrop. 2 vols. I $86,7-67$.

Young, Alexander. Chronicles of the Pilgrim Fathers. IS 4 I. 



\section{Some Important Dates in Puritan History.}

I324 John Wyclif born. Died I384.

1380 Wyclif's New Testament.

I525 Tyndale's New Testament.

I53 I Henry the Eighth acknowledged as Supreme Head of the Church of England.

I 535 Coverdale's Bible.

I 547 Edward the Sixth ascends the throne.

I553 Mary becomes Queen.

I 555 Persecution of Protestants begins.

I $55^{\circ}$ Elizabeth becomes Queen.

- Acts of Supremacy and Uniformity.

I 564 The name Puritan first used.

1565 The Dean of Christ Church, Oxford, imprisoned for Nonconformity.

I 572 Massacre of St. Bartholomew.

I 575 John Robinson born.

I 580 Separatist Church in Norwich under Robert Browne.

I583 Whitgift, Archbishop of Canterbury.

- Ecclesiastical Commission receives new powers.

- Two Puritans hung for Non-conformity.

1588 Defeat of the Spanish Armada.

I 588-89 Martin Mar-prelate tracts.

I593 Barrowe, Greenwood, and Penry publicly executed for their Non-conformity.

1602 The Separatist Church at Gainsborough.

I603 Death of Queen Elizabeth. James the First ascends the throne. Millenary Petition. 
I604 Hampton Court Conference.

I605 Three hundred Ministers expelled from their parishes for

Non-conformity.

I606 Church formed at Scrooby.

I607-0S The Pilgrims removed to Amsterdam.

I609 The Pilgrims Settled at Leyden.

I6I I Authorized Version of the Bible.

I6IS Thirty Years War begun.

I620 The Pilgrims land at Plymouth.

I621 Death of Governor Carver. Bradford chosen Governor.

1625 Charles the First ascends the throne.

I628 Endicott lands at Salem, with a colony.

1629 A Charter granted for the Massachusetts Company.

_ Agreement to settle in Massachusetts signed, in Cambridge, by Winthrop and others.

_- Re-enforcements sent to Salem, with Higginson.

- Puritan Church formed at Salem, August 6.

I630 Governor Winthrop arrives in Massachusetts with a large colony of Puritans.

- Boston settled. First General Court in Massachusetts.

I633 Laud, Archbishop of Canterbury.

I635 First Settlement in Connecticut.

I636 Harvard College founded.

I637 The first Massachusetts Synod.

- The case of John Hampden tried, in England.

1639 The Constitution of Connecticut adopted.

I640 The Long Parliament met.

- The Bay Psalm Book, printed.

1643-48 Westminster Assembly.

- Confederacy of the colonies of New England.

$16+4$ Death of Elder Brewster.

1646-48 Cambridge Synod. Platform of Church Government.

I649 Execution of Charles the First.

1651 Hugh Parsons tried in Springfield for Witchcraft.

I653 Oliver Cromwell, Lord Protector.

1656-62 Persecution of the Quakers.

1658 Death of Cromwell.

- The Savoy Synod adopts a Confession of Faith.

1660 The Restoration of the Stuarts. 
1662 The Boston Synod adopts the Half-Way Covenant.

I673 The first Church organized in Maine, at York.

The Act of Uniformity re-enacted in England.

I679 The Reforming Synod.

I680 The Synod adopts the Savoy Confession.

1691-92 Witchcraft in Salem and elsewhere.

I69I Charter of the Province of Massachusetts.

I 70 I Yale College founded.

i 708 The Saybrook Platform adopted.

1709 The General Association of Connecticut Ministers organized.

I 716 Yale College located at New Haven.

[727 Jonathan Edwards ordained, Northampton.

1734-40 The Great Awakening.

1738 The Methodists appear in London.

I740 Whitefield preaches in New England.

I750 Jonathan Edwards dismissed from Northampton.

I 754 Edwards' Work on The Freedom of the Will.

I758 Death of President Edwards.

1762 Church in Bennington, Vt., organized.

I 769 Dartmouth College founded. 


\section{Introduction.}

\section{By Alexander McKenzie, D.D.}

THE design of this book is a large one. While 1 many books have been written about the Puritans, a continued study of the men and their work is demanded, and will have an ample reward. The time seems to have come when they can be studied intelligently and impartially; and there is good reason to believe that the better they are known, and the more accurately their work is estimated, the more thorough will be the admiration which is the result. It is difficult for one to set himself back two or three centuries, and there rightly to judge the events which are around him. Yet it is the grateful and patriotic duty of every person in this country to gain for himself a distinct knowledge of the forces which made the beginning of our national life. We shall be helped to carry on the incomplete work, if we know the method and meaning of its origin. The very word origin presents a broad and inviting field for research. Whence came the name Puritan? "The Church of the Purity" is an old phrase; and if the name grew out of an ancient sneer, as has been suggested, it is well to know by what means, and by what men, it has justified 
itself, and changed a term of scorn to one of honor. Where shall the study of the Puritans begin? Certainly not on the coast of Massachusetts. Nor can it begin in England; nor in Holland. We are led back to events which concerned the entire history of Europe, as we follow the Puritan idea towards its inception. But what period of modern history is more helpful, and what historic line can be more clearly traced than this, as it runs in its unbroken way? It is not strange, but it is interesting to mark that the best account we have had of the earlier Puritanism is given by an English historian. The fine pages of John Richard Green are as instructive as they are delightful. It is a very full and compact sentence in which he describes the transition into which Puritanism was carried: "It ceased from the long attempt to build up a kingdom of God by force and violence, and fell back on its truer work of building up a kingdom of righteousness in the hearts and consciences of men." It is sincere and enlightened testimony which he gives, that Puritanism had made the mass of Englishmen "serious, earnest, sober in life and conduct, firm in their love of Protestantism and of freedom. . . . The history of English progress since the Restoration, on its moral and spiritual sides, has been the history of Puritanism." Surely there is room for diligent study, and no study is more essential here, and at this time, than that which makes us wise in our past that we may be prudent in our future.

There are several questions of interest which arise when the mind turns to this subject. One of these, 
and one of the largest, is suggested by the first part of the title of the work now before us, - Puritanism in England. What was this? What was its relation to the government and to the Church of England? What was England then, in itself and in its relation to the continent? There were three parties in the Church: those who were content with things as they were; those who were discontented, but proposed to remain where they were and work out such reforms as were possible; and those who boldly came out, and made a new start according to what they believed to be an older and a better way. Which was the better of the two plans of reformation, which has proved the more effectual, is a question for the student of history, especially the student of English and American history.

But this was not purely an English movement, even in its immediate working. We have always recognized the influence of their life in Holland upon those who sought refuge there from the persecution in England. That Leyden offered not merely hospitality and freedom, but the best school in the world for the training of men in the principles of liberty, and in endurance for the sake of liberty, is beyond question. The siege of Leyden was too near to have lost its influence over any who walked through the streets and among the houses where men and women had starved and died for freedom, or who looked across the fields over which ships had sailed bringing them bread. But of late there is an attempt greatly to magnify the influence of the Dutch upon the English. That the large 
numbers who came from Holland, and were associated in many ways with the English, were of great service, not merely in their handicrafts, but in their knowledge of religious liberty, should be promptly acknowledged. But to what extent this influence made Puritans into exiles, and then into Pilgrims, is a question to be calmly considered.

The connection between the Plymouth and the Massachusetts Colony, in men, in spirit, in method, in result, again calls for careful study. It is only by a comprehensive view of these separate, yet allied, movements that justice can be done to either Colony. Nothing can be settled by setting one point against another point. The two spheres of life must be compared, and this will be to the advantage of both.

It will be long before men agree upon the wisdom and justice of the Puritan polity in general, as it was developed here in Massachusetts. That the policy was narrow and strict may be at once admitted. Whether it could have been more lenient and flexible is a fair inquiry. It has been answered in various ways. In the spirit of our own times it is easy to say that a more liberal method of legislation would have been practicable, and in all respects better. On the other hand, some deference must be paid to the integrity and justice of the men who were in charge of affairs at that time. They were not weak, and they were not bigots. They had not made themselves exiles that they might prepare an arena where all kinds of beliefs might disport themselves. They had come three thousand miles, at a great cost of money and of feeling, that they might here 
make a better England according to their own convictions of that which was true and right. While, as the work of scusible men, their movement had a commercial quality, they weighed " the greatness of the work in regard of the consequence, God's glory and the Church's good." If others would join them in their enterprise, they were welcome. How far they should tolerate men and women who had different views of truth and duty, and allow them to teach their contrary opinions, in those early and critical days, may be still an open question. It is very likely that a wider toleration would have been less perilous than they supposed. They seem to have interfered with no person's opinions except in so far as these interfered with the things which they deemed essential to the safety of the Colony. If their rules were strict, banishment to Rhode Island does not seem to have been severe. Perhaps it was well that there was near at hand a pleasanter place than this eastern coast. Perhaps Utopia must always have its supplemental Narragansett.

It is not the province of an introduction to discuss these matters. There are many things of less import which are of interest in connection with the Puritans. These relate to the manner of their life here; their method of government; their churches and forms of worship; their homes and their domestic concerns; their books and schools; their charities and their sports; and all which made up their daily life. There is abundance of material for many intcresting pages which will make curious and instructive reading. 
But for all these things the reader must turn to the chapters from which he has been too long detained. I am confident that he will find here the results of honest and patient study, presented in an attractive way, with a style remarkably clear and strong; so that he is taken from chapter to chapter along pleasant paths, with an increasing knowledge of the Puritan and of all which the name stands for, and with a growing and abiding admiration of the ancestry to which every American owes so much. It will encourage the faithful study of a book like this to remember that the permanence and extension of the Puritan work depend upon us and those who shall come after us. We have a wonderful opportunity, but it is entirely in keeping with our wonderful history. It will encourage us still further if we can believe the generous prophecy of John Richard Green in his History of the English People: "In the centuries that lie before us, the primacy of the world will lie with the English People. English institutions, English speech, English thought, will become the main features of the political, the social, and the intellectual life of mankind. . . . In the days that are at hand, the main current of that people's history must run along the channel, not of the Thames or the Mersey, but of the Hudson and the Mississippi."

The First Church in Cambridge, March, ISg6. 


\title{
I. \\ The Puritan in England.
}

\author{
ERRATA.
}

Page 56, Hampton Court, not Hampden.

, 12I, Emmanuel College, not Emanuel.

. I2I, St. Botolph, not Buttolph. 
But for all these things the reader must turn to the clapters from which he has been too long detained. I am confident that he will find here the results of honest and patient study, presented in an attractive way, with a style remarkably clear and strong; so that he is taken from chapter to chapter along pleasant paths, with an increasing knowledge of the Puritan and of all which the name stands for, and with a growing and abiding admiration of the ancestry to which every American owes so much. It will encourage the faithful study of a book like this to remember that the permanence and extension of the Puritan work depend upon us and those who shall come after us. We have a wonderful opportunity, but it is entirely in keeping with 
I.

The Puritan in England. 


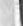




\section{The Puritan in England.}

$A^{M O N G \text { the great types of character that }}$ have left a permanent mark upon modern history we must place the English Puritans. Macaulay speaks of them as perhaps "the most remarkable body of men which the world has ever produced." Hallam says "the Puritans were the depositaries of the sacred fire of liberty." Hume writes that "the precious spark of liberty had been kindled and was preserved by the Puritans alone;" and that "it is to them that the English owe the whole freedom of their Constitution." Carlyle says, in his Introduction to the Letters and Speeches of Cromwell: "One wishes there were a history of English Puritanism, - the last of all our Heroisms, but sees small prospect of such a thing at present. Few nobler Heroisms, - at bottom perhaps, - no nobler Heroism ever transacted itself on this earth." Other writers on the history of the English people in the sixteenth and seventeenth centuries speak of the services which the Puri- 
tans rendered to religion and to freedom in similar terms.

It is considerably more than three centuries since Puritanism became a power in moulding the people of English birth and speech. Both England and America have felt their influence as well upon the political institutions of the people, as upon their intellectual development, and their religious life. If that influence has

Puritan influence in New been more decided in America than England. in England it is because the Puritans in this country had the advantage of working in the forming period of our history, when they were not limited by the power of established customs. For a hundred and fifty years our Puritan fathers and their descendants lived here an isolated and peculiar people. There was very little admixture of foreign blood. In this new country they were free to build the Church and the state according to their own ideas. During that period the New England spirit was developed, and embodied in the Puritan churches and colleges and schools, and in the political institutions of the New England colonies. About twenty-one thousand persons came from England within the twelve years between 1628 and 1640 . There was never afterwards any considerable increase of their numbers from England. From these twenty-one thousand 
people about one fourth ${ }^{1}$ of the present population of the United States have descended. The Puritan element in our population has been the controlling power in the republic. It has been modified by other influences, from Scotland, and France, and Holland, as the country has grown older, but on the whole, New England principles and institutions have been moulding the whole people and directing the policy of the nation.

\section{I.}

If we would understand the Puritans who planted the colonies on this side of the sea, we must trace their history back to the mother country. For our Pilgrim and Puritan fathers were a part of the great Puritan party which had been growing for about a Power of the which had been growing for about a Puritan party century before 1620 , and which was of in England. sufficient strength not only to plant colonies in New England, but also to overthrow the arbitrary power of the Stuarts, and establish the Commonwealth in 1649 , and, forty years later, to secure the political and religious liberties of the English people, by a revolution under William

1 Mr. Bancroft states that in 1834 one third of the people of the United States were descendants of the first settlers of Massachusetts. Vol. I. 375. Mr. John Fiske says one fourth the present population have come from them. "Beginnings of New England," I43. 
and Mary, which made England a free and Protestant kingdom for all time.

The history of the English Puritans is almost the same as that of the Protestant Reformation in England. It is plain that the beginning of the Reformation was at least as far back as the time of Wyclif, in the last half of the

Beginnings of the Reformation.

fourteenth century. He was born in the year I 324. He was the foremost among the scholars of his time. His spare and emaciated frame had been weakened by study, and by the severe discipline to which he subjected him. self. But within this frail form there was a mind of great capacity, - a restless and indomitable spirit, - and a conscience which directed all his life. He was the special friend of John of Gaunt, who was able to protect him from the power of the ecclesiastics. His great work was the translation of the Bible into English, and his defence of the right of every man to read the Scriptures in his own tongue. He denied the doctrine of transubstantiation, and asserted that, in the primitive Church, there were but two sorts of clergy. $\mathrm{He}$ was opposed to the multiplication of ranks in the clergy. He advocated a simple form of worship, and spoke against auricular confession. John $\mathrm{W}_{\mathrm{yclif}}$ : His protest was against the practices of 1324-1384. the Church, rather than against its doctrines. He was the father of our English prose, 
as Chaucer was the father of English poetry. He made his appeal boldly to the people, against the threats of the ecclesiastics. "I believe that in the end the truth will conquer," he said. $\mathrm{He}$ issued a multitude of tracts in the language of the common people, in which he attacked the worship of the saints and of images, the idle and scandalous lives of the clergy, pardons, indulgences, and pilgrimages to the shrines of the saints. He organized and sent forth an order of preachers, who were called "Simple Priests." They went everywhere among the people, wearing the long russet-dress by which they were known; and they preached the doctrines of Wyclif so forcibly, that it was said, a few years later, "Every second man you meet is a disciple of Wyclif." They were found in the cities as well as among the peasants of the country. Some of the nobility, and some of the men of learning, adopted his opinions.

If Wyclif had lived a hundred and fifty years later, it is very likely that the Protestant Reformation in England would have been developed under his lead, somewhat as

The Lollards. the Reformation in Germany was under Luther. But $\mathrm{W}_{y}$ clif had not the advantage of the printing-press, nor of the great intellectual awakening that accompanied the revival of learning. The people of his time, although they wel- 
comed the truths which he gave them, were not intelligent and stable enough to hold and transmit these truths, in spite of the determined opposition which they aroused. The severe persecution which followed his death checked the progress of his doctrines. His followers were called Lollards - that is, idle babblers - by their enemies. Very severe laws for the punishment of heresy were enacted in the reign of Henry the Fourth. Thirty-nine prominent Lollards were put to death in a single year; and a much larger number of the common people. The movement for reform lost the vigor and hopefulness which it had shown at the outset. But it continued to live through the next century and a half. Little is said about it by the historians, except when the movement showed its power in some struggle for the rights of the people against arbitrary power. Passages from Wyclif's Bible and from his tracts were copied by hand and passed about from cottage to cottage. The Lollard preachers, clad in their long russet robes, with their pilgrim staves, went barefoot from village to village, reading the Word of God to the common people, and making them familiar with its teachings and its histories. This was the preliminary work of the Reformation. The Lollards were the Puritans of the fifteenth century. They were numerous in the eastern counties 
of England, the very section where, at a later time, Puritanism had its greatest strength. As late as 1520 , the Bishop of Lincoln reported that Lollardism was very troublesome in his diocese. As many as two hundred heretics were brought before him in the course of a single episcopal visitation.

II.

THE Reformation in England in the sixteenth century was very different from the Reformation that was in progress on the continent. In England, the movement was not religious but political. On the continent, it was intensely religious. This distinction is important because it is probable that if the Reformation in England had been like that in Germany and in Switzerland and in France, there would have been no such thing as the Puritan party Reformation in no such thing as the Puritan party England and in England. All over Europe there in Germany. had been a preparation for a great movement for the reform of the Church. The books of Wyclif had been read as far away as Bohemia. There was a new interest everywhere in the Bible. Men were longing for a simple gospel. Luther was prepared for his work as the leader of the Reformation by a very deep religious experience. "Ah," he exclaimed, at one time, "with what anxiety and labor, with what searching of the 
Scriptures, have I justified myself, in conscience, in standing up alone against the Pope." "Here I take my stand," he said, in the presence of the Diet, and of the Emperor; "I can do naught else. May God help me. Amen." It was this deep religious spirit which made the words of Luther so effective. Those who had been longing and praying for a reform were eager to join the great movement. The Protestants all stood together, in opposition to the errors against which they protested.

But in England the movement for separation from the Church of Rome began with the king, not with the people. Henry the Eighth was never a Protestant, in the sense in which the German Reformers were. $\mathrm{He}$ had earned the title of Defender of the Faith by his book in reply to Luther's work on the Sacraments. The books of Luther were solemnly burned at St. Paul's, and orders were issued for the persecution of heretics. To the end of his life, Henry was in most respects a Romanist. The Law of the Six Articles, which he approved, sanctioned the sacrifice of the Mass, the communion in one kind, the celibacy of the clergy, monastic vows, private masses, and auriculary confession. The so-called Reformation in his reign was incomplete and superficial. He broke away from the Church of Rome for reasons that were personal 
and political, rather than religious. Virtually, the Church of England exchanged one Pope for another. Henry denied the supremacy of the Pope, but made himself the head of the English Church. He condemned to death those who denied transubstantiation, and those who denied his supremacy over the Church.

\section{III.}

YET all through his reign the Reformation was making progress among the people. The new translations of the Scriptures, by Tyndale and Coverdale, were printed and scattered far and wide. Later in the reign, the king ordered the English Bible to be read in the churches.

In the short reign of Edward the Sixth, the Protestant Book of Common Prayer was issued, and a Protestant Confession was prepared and imposed upon the Church by authority. But Queen Mary restored the Mass, set aside the new Prayer Book, and, as far as practicable, brought back England to its old relations to the Church of Rome. The great majority of the priests, and of the people accepted the changes. But there were many who held tenaciously to the Protestant faith. More than three hundred were burned at the stake, and their constancy 
gave new strength to their cause. Eight hundred more whose lives were in danger escaped beyond the sea, and spent the years of her reign in close association with the Protestants on the continent. When Latimer was burned, he said, "We shall this day light such a candle, by God's grace, in England, as, I trust, shall never be put out." When Cramner, the Archbishop of Canterbury, was led to the stake, the act excited feelings of abhorrence among the people. His martyrdom has been regarded as the death-blow to Catholicism in England.

\section{IV.}

THE accession of Elizabeth to the throne, in I558, was the critical period in the history of the English Reformation. The young queen was commonly believed to be a Protestant, although she had conformed to the Catholic ritual during the reign of Mary. Her first acts encouraged the hopes of the Reformers. She released all the prisoners confined for their religion by her sister, and encouraged the Protestant exiles to return to England. She kissed the English Bible which the people of London presented to her, and promised "diligently to read therein." She restored the Book of Common Prayer, which had been hallowed by the suffer- 
ings of the martyrs; but she caused certain alter. ations to be made in the Book, which were designed to recommend it to the Romanists. She said to the Spanish embassador, "I shall do as my father used to do." By the Act of Suprem. acy, passed in the first year of her The Act of reign, the queen was declared to be supremacy. the supreme governor of the Church, authorized to nominate all bishops, and to correct all heresies. All those who held benefices or offices were required to take the Oath of Supremacy, avowing the queen to be the only supreme governor within the realm, "as well in all spiritual and ecclesiastical causes and things as temporal." It was provided by the Act of Uniform- The Act of ity that the Book of Common Prayer Uniformity. should be used in all public religious services, and that any minister who should refuse to use it, or who should use any other rites and forms than those therein set down, should forfeit his salary for one year, and be imprisoned for six months; and that for the second offence he should lose his benefice, and be imprisoned for a year; and for the third, he should be imprisoned for life. ${ }^{1}$ Persons not in orders who should thus offend, were to be punished with equal severity. The ceremonies of the Church, and the dress of the clergy, were to be as in the time of King Edward.

1 I Eliz. cap. I, sect. I I. 
The queen only had power to make changes in these matters.

It was these acts which really formed the Puritan Party in England. The Puritans were origin of the those who were "for carrying the ReforPuritans. mation to its logical results." There were certain things among the forms and ceremonies of the Established Church to which they could not conform with good consciences. The fires of Smithfield had intensified the Protestantism of the English people. The exiles who came back from the continent were full of admiration for the simplicity of Protestant worship abroad. "Protestantism," says Mr. J. R. Green, "had become a fiercer thing; and was pouring back from Geneva with dreams of revolutionary changes in Church and state." Many things in the ritual of the Church of England seemed to them to favor the errors and superstitions of the Church of Rome. The contest was not, at that time, in respect to the doctrines of the Church, nor in respect to the Episcopal form of Government. It related to forms and ceremonies and vestments. These were immaterial in themselves, and yet each one of them at that time had a doctrinal significance. We have seen, in our own times, something of the intensity of ritualistic controversies. But in that age such matters touched the life of the Church much more closely. 
The separation from Romanism was still recent. The majority of the English people were probably Romanists when Elizabeth ascended the throne. The Protestant minority, however, included the ablest and most powerful men in the kingdom, and they were not in a mood to accept, under a Protestant queen, any modes of worship, or of the administration of the Sacraments, which were suggestive of the Real-presence in the elements at the Lord's table, or of a superstitious regard for the Cross, or of any of the practices of the old Church which they had renounced. They were protesting against transubstantiation, when they refused to kneel at the altar to receive the elements at the Supper. They objected to the use of the sign of the Cross in baptism, and the use of the ring in marriage, and to the use of clerical vestments, especially to the use of the cap and the surplice, not because they were wrong in themselves, but because they could not use them without seeming to sanction opinions which they deemed inconsistent with the truth which it was their special mission to defend. New and better associations, and the mellowing influences of time have made these things quite indifferent to us; but it is not difficult to understand how significant they were three centuries ago. 


\section{V.}

In the early years of Elizabeth the acts of Supremacy and of Uniformity were not executed very strictly. They were put in force first against the Roman Catholics. Under their provisions all the bishops except one lost their places. The Protestant exiles who had returned, were welcomed by the Church, and a number of them were appointed to the vacant bishoprics. Only about two hundred of the parish priests lost their livings, out of some seven or eight thousand. The changes were generally in favor of the progress of the Reformation among the people.

The Act of Uniformity was administered more strictly as the years went by. The Court of High Commission, under the Archbishop of Canterbury, was clothed with ample powers for carrying these laws into effect. About the year ${ }_{1564}$, the word Puritan began to be used, not at first as a term of reproach, but to designate those who sought the purest form of worship, - " religio purissima." They desired to remain within the Church; but they refused to conform to practices which seemed to them the badges of Rome. A large proportion of the clergy of the Established Church were Puritans. So were a number of the bishops, and some of the archbishops.

In 1565 , the Commission sent to prison the 
Dean of Christ Church, O:ford, because he refused to wear the required vestments. The same year all the clergymen of London the Puritans were brought before the Commission, before the and asked to promise to conform to all commission. the requirements of the Prayer Book. Thirtyseven out of ninety-eight refused to give the promise; and they were suspended from the ministry, and deprived of their livings. Miles Coverdale, one of the translators of the Bible, was deprived of his parish for non-conformity, in the eighty-third year of his age. John Foxe, the Puritan author of the Book of Martyrs, also refused to conform; but he was suffered to go in peace, on account of his great reputation; and he held his small office in the Church until his death. When the Puritan ministers of London were driven from their churches in 1565 , their followers held meetings in private houses, and in public halls, without any disorder, and listened to the Bible, and the sermons of their ministers. A congregation of this sort was arrested by the sheriff in 1567 . The only charge against them was that they were worshipping God under forms not prescribed by law. They were found guilty of this offence, and a large number of them were sent to prison for a year. ${ }^{1}$ The next year the

1 Neal's History of the Puritans, I. I08; Hallam, I. IS6 ; Campbell's Puritan in England, Holland, and America, I, 400-447. 
Spanish embassador, writing to Philip, said: "Those who call themselves of the religio purissima go on increasing. They are styled Puritans, because they allow no ceremonies, nor any forms save those which are authorized by the bare letter of the gospel. They will not come to the churches which are used by the rest, nor will they allow their ministers to wear any marked or separate dress. Some of them have been taken up ; but they have no fear of prison." 1

The work of silencing the Puritans went on from year to year, with increasing severity; and yet they still clung to the Protestant Church of the realm, and tried to do their work under its shadow. When they were expelled from their livings for non-conformity, they obtained employment as preachers for the regular incumbents, who were too ignorant or too indolent to preach themselves, or they took refuge in the families of the gentry, where they found a useful employment as teachers. Their books were suppressed; their private meetings were broken up; and even private citizens were brought before the High Commission, and punished for non-conformity.

In $15^{8} 3$, Whitgift, whom the queen used to call her "little black parson," was appointed Archbishop of Canterbury, that he might "root out Puritanism and the favorers thereof." The

1 Froude, ix. 327. 
next month after his appointment, he issued orders for the enforcement of religious discipline throughout the realm. Two months later, the court of High Commission was made a permanent institution to enforce the acts of Uniformity. This court was continued for fifty years. Whitgift issued orders forbidding all preaching, reading, or catechising in private houses. This was intended to prevent the assembling of neighbors to read the Bible, or for any religious service. It was also provided that no one should assume the functions of a clergyman unless he had been admitted to holy orders in the Church of England. All clergymen were required to subscribe a declaration of approval of the Thirty-nine Articles, and of the Book of Common Prayer, as containing nothing contrary to the Word of God; and also a promise to use its forms of prayer, and no other. These requirements went beyond the laws, but they were enforced with unsparing vigor. Several hundred of the best ministers in England were silenced, and their parishes were left destitute. It was a short matter: Do you wear the surplice? Do you make the sign of the Cross in baptism, and use the ring in marriage, and require communicants to kneel when they receive the Communion? If not, you must cease to preach, and give up your salary. No witnesses were necessary. The accused was 
put under oath, and required to criminate him. self. The methods of the High Commission under Whitgift were as relentless and as unscrupulous as those of the Inquisition.

\section{VI.}

These extreme measures were for a time suc. cessful. A uniformity of worship was brought about. The Puritan ministers, whose nonconformity had sometimes been winked at, were now driven from their pulpits. The press was placed under a strict censorship. No book could be printed except with the approval of the Archbishop of Canterbury, or the Bishop of London. No printing-presses were allowed in any part of England outside London, except one in each of the Universities. This was the decree of the Star Chamber, issued at the instigation of the Archbishop. The effect of all this was to deepen the convictions of the Puritans, and increase their influence in the country. Nore and more the attention of the people was directed to the Bible. It was read everywhere. It became the one book with which every Englishman was familiar. It colored the common speech of the people. The old Prophets lived again as God's messengers to their nation; the imagery of the Bible moulded their common speech. This 
familiarity with the Bible gave the people a more serious spirit, and a higher view of the meaning of life. "Theology rules here," said a discriminating foreign observer, in London, in one of the later years of Elizabeth. The pressure brought to bear by the High Commission set everybody to reading religious books. A multitude of such books and pamphlets, printed on the continent, found their way across the Channel, and were eagerly read. For a long time the great subjects of discussion in England related to the Church and its modes of worship.

\section{VII.}

Ose result of the arbitrary measures of the High Commission was the division of the Puritans into two sections. The larger the ronnumber of the Puritans continued to conformists. be simply Non-Conformists. They claimed their rights as Protestants in the Church of England, but refused to conform to certain of its requirements. The Separatists, however, renounced their connection with the National Church, and formed themselves into independent churches. with the simplest possible organization, and a plain and simple form of worship. They were the people who insisted upon "reformation with. out tarrying for any:" From them have sprung 
the great body of dissenting churches in Great Britain, and the Independent and Congregational churches in America.

It is not easy to tell where Separatism had its beginning. As early as the time of Queen Mary, there were small companies of Christians who origin of the were accustomed to meet in private separatists. places for religious services, and who disowned the Established Church. All through the reign of Elizabeth, there were such gatherings in London, and in northern and eastern England. The first organized Separatist Church of which we have any definite account was formed in Norwich, about the year I5So, by Robert Browne, a graduate of Cambridge, and a relative of Lord Burghley, a favorite Minister of Queen Elizabeth. From him the Separatists received the name of Brownists. He published a number of books which were widely read, in which he set forth his views in regard to the constitution of a Christian church, and also in regard to the relation of the state to the Church.

He held that the state, as such, has no ecclesiastical authority at all: so that the Church should Views of have no connection with the state exRobert Browne. cept such as grows out of its secular relations. He believed that the Church of England had become so corrupt that it was impossible to secure discipline within it. Not only 
the most worldly people, but those whose lives were scandalous, had a legal right to partake of the Lord's Supper, side by side with the very elect and anointed of God. It was therefore the duty of true Christians to separate from that Church, and to follow Christ elsewhere.

In respect to the Constitution of the Church itself, Browne held these principles:-

First: That any company of Christians who covenant with God and with each other to walk according to the teachings of Christ, and to engage in His service, and His worship, and who observe the Sacraments, is a true Church, and is independent of all control but that of the divine Head of the Church. ${ }^{1}$

Second: The government of the Church rests with Christ in the first instance, and through Him it comes to the members of the Church, as His disciples united in His name. "The Church government," Browne says, "is the Lordship of Christ, in the Communion of His offices, whereby His people obey $\mathrm{His}$ will, and have mutual use of their gifts and callings to further their godliness and welfare." So that the members of the Church are to decide all questions which properly come before it, subject only to the authority of Christ.

Third: The officers of a church are the pastor,

1 Treatise on Reformation without tarrying for any. 
and the teacher, who are to teach the Word, and exhort to good works, and true obedience; and one or more elders, "for oversight and counsel, and redressing things amiss;" and one or more deacons, or deaconesses, to care for the secular matters of the church, and to visit the sick, and the afflicted, and to relieve the wants of the poor.

These principles seem harmless enough at this day, but at that time they were regarded as "strange and dangerous doctrines." The minister was arrested and imprisoned for preaching them. The little church in Norwich which accepted these principles was compelled to leave the country, in order to find a place where it would be free to worship according to this way. Robert Browne was in prison thirty-two times in the course of the next six years. Some of the dungeons in which he was confined were so dark that he could not see his hand at midday. He was only safe from arrest when he was outside the kingdom. At length, worn out by persecution, broken in mind as well as in body, he gave up the contest, returned to the Established Church, and accepted a small parish where he spent the later years of his life in peace and obscurity.

About the year $15^{8} 7$, we find traces of congregations of Separatists in London. They met

${ }^{1}$ Dr. H. M. Dexter, on Congregationalism, I 6-i2S. 
sometimes in private houses, and sometimes in the fields outside the city. At these meetings they used to read and expound the Scriptures, and to pray. The officers were always in quest of them, for such

Separatist Churches in

London. services were contrary to the Act of Uniformity. As many as sixty persons were sometimes present at these meetings, while a much larger number were interested in them. So many were imprisoned, that at some seasons the number in attendance was less than twenty. Sometimes they were nearly all in prison at once, and then they would hold their religious services in the prison. Fiftynine of them were incarcerated in the various prisons of London at one time. Some of these prisoners were kept in irons. Some were without proper food. A list has been preserved of twenty-five who died in prison; twenty of these were men, and five were women. ${ }^{1}$

Governor Bradford states in his history that at least six of the Separatists were publicly executed for their non-conformity. ${ }^{2}$ These were John Coppin, William Dennis, Elias Thacker, Henry Barrowe, John Greenwood, and John Penry.

Of the three whose names are first in the list, little is known except that they were publicly executed as Separatists, after long periods of

${ }^{1}$ A true Confession, et cetera - I596, quoted by Dr. Dexter.

2 Bradford's History. 
imprisonment. Coppin and Thacker were tried for selling the books of Robert Browne, and for heresy. Thacker was hanged at St. Edmunds in Suffolk, June 4, 1583 , and Coppin on the following day. The moral effect was heightened - so the Chief Justice wrote - by the fact that about forty of the books of Browne and Harrison were burned at the same time.

Of the three others we have fuller accounts, which they prepared before they were put to

Trials of death. Henry Barrowe was arrested in Barrowe and November, 1586 , and was kept in prison
Greenwod.

the most of the time for about seven years. He was a graduate of Cambridge, and a member of Gray's Inn. While in prison he published a number of books, in which he set forth his opinions in regard to the Church of England. He was finally condemned to death for publishing seditious books. He was reprieved by the queen the next day; and efforts were made to induce him to retract. It was in vain, and, after being a second time reprieved, he was hanged at Tyburn the 6th of April, I593.

His friend and fellow prisoner, John Greenwood, was also a graduate from Cambridge, and a clergyman of the Church of England. $\mathrm{He}$ had scruples in respect to his connection with that Church, and finally withdrew from it and joined the Separatists. He was arrested in 1586 , 
for holding a private religious meeting at the house of Henry Martyn in London. After six years in prison, he was released, and returned to the meetings of his old friends, the Separatists. $\mathrm{He}$ was again imprisoned, and, in 1593, was tried for publishing seditious books. He was found guilty, and was sentenced to death. On the 6th of April, 1593, he was hanged at Tyburn, with his friend Barrowe.

John Penry was born in Wales, took his degree of B. A. at Cambridge, and that of M. A. at Oxford. He took orders in the Episcopal Church, and preached both John Penry. at Oxford and at Cambridge. He also became a Separatist, and was committed to prison. $\mathrm{He}$ was kept on bread and water, although his wife asked permission to provide him something better, pleading that he was "a very weak and sickly man." It was not easy to find any pretense for condemning him, because he had not published any books since he became a Separatist. But his private papers were seized, and among them was found the first draught of a petition to the queen. It had not been finished, or published. He protested that this writing was a part of his private diary, and that no creature under heaven knew of it except himself, until it was seized by the officers. But he was brought to trial for "speaking and writing against 
the queen, and for defaming her Majesty." $\mathrm{He}$ was found guilty, and was executed at St. Thomas Waterings in Surrey, May 29, I 593. The best use that Elizabeth Tudor had for these honest and independent men was to hang them by the neck until they were dead. ${ }^{\mathbf{1}}$

\section{VIII.}

The Puritans were helpless under the arbitrary power of the State Church; but they

The Martin Mar-prelate Tracts.

still made their appeal to public opinion, that power which in the modern world is stronger than princes and hierarchies. They could not lawfully own printing-presses, or print books, without the approval of the Archbishop. But a new turn was given to the controversy by the sudden appearance of a series of pamphlets bearing the name of Martin Mar-prelate, - gentleman. There were seven of them published within about seven months, between the early winter of 1588 , and midsummer I58. It has been said that the Puritans lacked a sense of humor, but the keen wit and satire of these pamphlets made them the most effective weapons for the Non-Conformists. The pamphlets were of necessity anonymous; and the secret has

1 Waddington's Historical Papers: Congregational Martyrs, 173. 
been so well kept that no one knows, to this day, who Martin was. The press on which they were printed was concealed in private houses, and carried from place to place in a cart to escape the officers. Four of the pamphlets were printed upon this press. When at last it was seized, Martin procured another, so that the remaining pamphlets were printed in due time. A royal proclamation forbade the owning or reading of these tracts: but the students of the Universities hid them in the folds of their gowns; even the nobles read them; the Earl of Essex presented one to the queen; and all England was laughing at the shrewd and audacious attacks upon the prelates. There was a certain coarseness about them, which belonged to the age, but there was nothing indecent or blasphemous. "Now prelates," said Martin, assuming an easy equality with the bishops, "I give you more counsel. Repent. Give over your lordly callings. Reform your families and your children. Pray her Majesty to forgive you, and the Lord first of all to put away your sins. Write no more against the cause of the Reformation. Punish nobody for refusing to wear popish garments, or for omitting popish corruptions from the Prayer Book, or for not kneeling at the Communion table. Study more than you do, and preach oftener. Take no more bribes: leave your simony. In a word, 
become good Christians. Let me hear no more of your evil doings."

Vigorous and systematic efforts were made to break the force of these attacks. The police force was ordered to spare no pains to discover and arrest the author of them. An elaborate reply to Martin's first pamphlet was prepared by one of the bishops. It was a ponderous quarto of two hundred and fifty-two pages. The effect of this reply was to add to the importance of the pamphlet, and to prepare the people to read the second, which was issued a few weeks later. As the other pamphlets of the series appeared, there were other replies. The bishops quoted Latin abundantly, and Martin quoted as much as the bishops. It was a number of years before the echoes of the discussion died away.

\section{IX.}

THEse were only incidents in the great movement of the English people toward a thorough Growth of reformation. It was not hindered by Puritanism in the Reign of persecution. It had been growing Elizabeth.

stronger all through the reign of Elizabeth; and when she died, in 1603 , it is probable that the majority of her subjects were of the Puritan party. The people were gaining in intelligence. The printing-press was a 
great power, though it was not yet free. The books which could not be printed in England were sent abroad for publication, and when they came back they were eagerly read by the people. For the first time in English history, an enlightened public opinion was springing up.

One cause of the growth of Puritanism was the unfriendly attitude of the Catholic powers toward England. The Pope called upon Elizabeth, at the beginning of her reign, to submit her claims to the throne to his tribunal. After she had declared herself a Protestant, the Pope issued his bull of excommunication, deposing the queen, and releasing her subjects from their allegiance. The Catholic nobles in the north of England raised the standard of rebellion. There were a number of plots to assassinate the queen; and these plots were traced in most instances to Roman Catholics. The latest of these plots was approved by Mary of Scotland, and the discovery of her complicity in this plot led to her execution. The Spanish Armada, which sailed in July, $\mathrm{I}_{5} 88$, was intended to encourage a rebellion of the Roman Catholics of England. The plan had the approval of the Pope. ${ }^{1}$ Three hundred priests were sent over to organize the revolt. They circulated a book which taught that it was the duty of the people to take up arms at the bidding of the Pope, and to fight

1 Green's History, vol. ii. 439. 
for the Faith against the queen and other heretics. The Puritans were the leaders in the splendid uprising of the English people, of all faiths and of all classes, which secured the defeat of the Armada. It is not surprising that since that day the great body of the English people, have regarded Romanism as a menace to the very existence of the nation.

The sufferings of their fellow Protestants on the continent added to the intensity of feeling among the English Protestants. The Massacre on St. Bartholomew's day, in 1572, by which, according to the most conservative writers, more than twenty-two thousand Protestants, including women and children, were cut off, filled England with horror. In that awful hour, says Mr. Campbell, the Spanish king laughed as he had never laughed before, and the Pope ordered a special Te Deum to be sung.

Still more fearful were the cruelties of which the Spaniards were guilty in their war against the Protestant provinces in the Netherlands. The Duke of Alva boasted, at the time of his departure from the Netherlands, that within six years he had executed eighteen thousand six hundred heretics and traitors. ${ }^{1}$ A large number of the Dutch Protestants found refuge in England.

1 Campbell's Puritan in Holland, England, and America, vol. i. 212 and $488-490$. 
They settled in the eastern counties, and became permanent citizens there. The narratives which these refugees gave of the unspeakable sufferings of their countrymen under the tyranny of their Roman Catholic king had more influence in England than even the Massacre of St. Bartholomew. Large numbers of the French Huguenots also settled in England. The story of the sufferings of the Protestants was told with wonderful pathos and vividness in Foxe's Book of Martyrs. This book was set up in the parish churches by order of Queen Elizabeth, and was read by the people more than any other book except the English Bible. The influence of these Protestants from the continent was seen in the marvellous vigor of the Puritan party in the seventeenth century, in the eastern counties, where some hundreds of thousands of these exiles made their homes. It is well known that the first settlers of New England came in the largest numbers from eastern England.

One other cause of the spread of Puritanism in the later years of Elizabeth should be mentioned. England and Scotland had come to stand almost alone as Protestant powers. The hopes of the earlier reformers of a complete purification of the Church had been disappointed. France had seemed at one time likely to become a Protestant country; but the Huguenots had been driven into 
cxile, and scattered over the world. The United Provinces had been trodden under the heel of the oppressor. A part of them had accepted the rule of Spain ; and few believed that the heroic struggle of the Dutch Protestants could succeed. In Germany, the Catholic powers were steadily gaining, and the Protestants were already on the defensive. The Thirty Years War was near at hand. The cause of the Reformation seemed to depend upon the fidelity of the English people.

This was the urgent reason for pushing the Reformation in the English Church to its logical results. The Established Church has grown out of a series of compromises between those who still favored some of the practices of the Romanists, and the radical reformers who had adopted the theology and the polity of the reformed churches on the continent. The Puritans held that it was dangerous, at that crisis, to halt between two opinions. They demanded the abolition of Romish ceremonies, and the training of an intelligent ministry, who should be competent to teach the people. They complained that a large proportion of the parish priests were ignorant, and of scandalous lives. The Puritans of the House of Commons presented an address to the queen, in $157 \mathrm{r}$, in which they said: "Great numbers are admitted to the ministry that are infamous in their lives, so that the Protestant 
religion is in great peril." ${ }^{1}$ Another petition complained that the ministers who were competent had been silenced for non-conformity, and that such as were left were unfit for the office, "having been either popist priests, or shiftless men thrust in upon the ministry when they know not how else to live, - serving-men, and the basest of all sorts, men of no gifts. So they are of no common honesty, rioters, dicers, drunkards, and such like, of offensive lives." The Council made an examination of the statements contained in this petition, and they reported that the statements were correct. ${ }^{2}$ With such a state of things within the Church, the best men of the nation made common cause with the Puritans in their demand for a thorough reformation. "Why," asked Lord Bacon, "should the civil state be purged and restored by good and wholesome laws, made every three years, in Parliament assembled, devising remedies as fast as time breweth mischief, and the ecclesiastical state still continue upon the dregs of time, and receive no alteration these forty-five years or more?"

\section{$\mathrm{X}$.}

Through the later years of Elizabeth the Puritans had waited, in the hope that when her successor, James the First, should ascend the throne, the way would be open for the reformation of the

1 Campbell, vol. i. 466.

${ }^{2}$ Strype's Whitgift, 167-r68. 
Church. James had hardly crossed the border, on his way to London for his coronation, when The Millenary he was met by what was called the MilPetition. lenary Petition, with the signatures of some eight hundred of the English clergy. This contained the proposals of the Puritan ministers for the reformation of the Church. They did not ask for any change in the government or the organization of the Established Church. The great body of the Non-Conformists would have been satisfied to continue under the rule of bishops, and to use the Book of Common Prayer in worship. The proposals which have been recently made by the Lambeth Conference for the union of all branches of the Church under the Historic Episcopate would have been entirely satisfactory to the Puritans. What they asked was: the Requests of the omission of the sign of the Cross in Puritans. baptism, of the ring in marriage, of bowing at the name of Jesus, of the lessons from the Apocrypha in public worship, and the omission of the cap and surplice; that the music used in the churches be made plainer and simpler; that the Lord's day be hallowed; that none be made ministers who were unable to preach ; that candidates for the Communion be examined as to their fitness; and that discipline be attended to more strictly. ${ }^{1}$

${ }^{1}$ Gardner's History of England from the Accession of James I., vol. i. I63. 
These proposals were certainly moderate; the most of them have been long ago adopted by the English Church. The Petition was an honest effort at comprehension which would have led to important results if it had been welcomed by the king and the bishops. Lord Bacon, who was far from being a Puritan, sent forth at that time a plea that things which are not essential be left "to the holy wisdom and spiritual discretion of the master builders and inferior builders in Christ's Church." He advised the king that it would be proper and expedient to institute such reforms as those which the Puritans had asked for. ${ }^{1}$

King James received the Millenary Petition graciously, and promised a conference of bishops and divines in which it should be discussed. Ten months later, he summoned four Puritan ministers to meet the Archbishop of Canterbury, and eight of the bishops, and seven deans, at Hampton Court. The proposals of the Puritans were discussed for three days; the King himself, who has been called the "wisest fool in Christendom," took the leading part in the discussion. One suggestion of the Puritan divines for a new translation of the Bible was received with favor. This was afterwards carried out, and the author-

1 Bacon's Works. Montagu's Edition, vol. ii. 420-430, on the Pacification of the Church. 
ized version of I6I I was the result. But the propositions for a reform in the Church met the decided opposition of the king and of all the bishops. They were unwilling that any matters of form or ceremony should be left to the discretion of the clergyman who conducted the public services. "I will have one doctrine, one discipline, one religion, in substance and in ceremony," said King James; "I will make them conform, or I will harry them out of the land, or else worse." The aged Archbishop of Canterbury exclaimed: "Undoubtedly your Majesty spake by the special assistance of God's spirit." And Bancroft, the Bishop of London, fell on his knees, and said, "There has been no such king since Christ's time." Soon after, the Convocation, with the approval of the king, passed a series of canons which forbade, on penalty of excommunication, the least deviation from the Prayer Book, or any disparagement of the established system of government and worship in the Church.

\section{$\mathrm{XI}$ 。}

The Puritans were disappointed, but not cast down. They had hoped for favorable changes from the new king. He had been bred a Presbyterian, and a Calvinist; he had subscribed to the Solemn League and Covenant, and had 
praised the Scottish Church as the "sincerest in the world." He had spoken, while in Scotland, of the Anglican Service as "an evil said Mass in English." ${ }^{1}$ They had hoped that one coming from another Protestant nation would be prepared to mediate between the parties in the English Church; and they expected that he would receive with favor the proposals for union with liberty, and mutual charity. The grand opportunity of uniting English-speaking Protestants in one Church, with one way of worship, was lost, and the divisions, which have lasted till our own time, have resulted from the mistakes of that critical time.

The half century, that followed the accession of James the First, was the great age of Puritanism. The contest soon passed beyond ecclesiastical matters, and became political as well as religious. The king opposed his prerogative to the Constitutional rights of Parliament, and of the people of England. The Puritans took the lead in this contest on the side of liberty in the state as well as in the Church.

\section{XII.}

THE causes which led to this broadening of the questions in debate are not far to seek. The first is to be found in the fact of the union of 
Church and state. The new king assumed for himself prerogatives which had never been conReasons of ceded by the English people, and he was the Political supported in these claims by the prelthe contest. ates of the Established Church. So that the Puritans, in their contention for the right to worship according to their convictions, found the power of the king and of his council arrayed against them. The character of the new king also gave a new turn to the controversy. Elizabeth had been diplomatic, if not always sincere. She knew how to keep in touch with her people, and she never attempted to force upon them a

Character of James the First. great measure to which they were opposed. The greatness of the queen was shown when she acknowledged her mistakes to her people, and adopted the measures which they called for. But James never understood the English people. He allowed himself to drift into a position of opposition to their wishes. He was as obstinate as he was wrong-headed. He dissolved one Parliament after another because the Commons insisted, by a very large majority, upon calling for a redress of grievances before voting the supplies. He said at one time, "As it is atheism and blasphemy to dispute what God can do; so it is presumption and a high contempt in a subject to dispute what a king can do." 
The position which the clergy of the Established Church assumed as the defenders of the royal prerogative, and of the divine right of kings, and of the duty of passive obedience, tended to give a political character to the Divine the contest. When the king joined Right of Kings. with the Church in setting forth these arbitrary claims, the Puritans were led by the logic of events to take the lead in asserting the liberties of the people. "England is the last monarchy that retains her liberties," said Sir Thomas Phillips; "let them not perish now."

Another reason - if we accept the views of the most eminent English historians - was their theological system. "Logically carried out," says Mr. Campbell, "Calvinism is democratic in its teachings." "The

Calvinism and the Rights of the People. meanest peasant," says Mr. J. R. Green, "once called of God, felt within him a strength that was stronger than the might of kings. In that mighty elevation of the masses, which was embodied in the Calvinistic doctrines of election and grace, lay the germs of the modern principles of human equality." ${ }^{1}$ Whether we accept this theory of the natural tendency of the system of the Genevan reformer or not, it is true historically that Calvinists have always stood for the rights of the people in opposition to arbitrary power.

1 Green, vol. iii. 45. Campbell, vol. ii. I0-12. See also Froude, Bancroft, Fiske, and others. 
The High Church party began at this time to put forth claims which separated them further

The Divine

Right of

Episcopacy. than before from the Non-Conformists. In the reign of Elizabeth, Prelacy had been advocated as a form of church government which stood upon its merits as a useful and ancient polity. ${ }^{1}$ The great men of that age never denied that a church without a bishop might be a true church, or that a minister, who had not received Episcopal ordination, might have a true and valid commission. They recognized the Protestant churches on the continent as true churches. In repeated instances the English Church had recognized Presbyterian ordination as valid, and had admitted Presbyterian ministers to benefices in the English Church without re-ordination. It was held that the Prayer Book did not require such re-ordination. This liberal spirit of fellowship with Protestant churches that were not Episcopal was very grateful to the Non-Conformists. A recent writer has stated that the doctrine of Apostolical Succession was not to be found in the writings of the Elizabethan divines until the celebrated sermon of Bishop Bancroft was preached, in the year of the destruction of the Armada. ${ }^{2}$ A more conservative

${ }^{1}$ Macaulay, vol. i. 58, 59. Green, iii. 157, I 58. Campbell, ii. 367 .

${ }^{2}$ Contemporary Review, November, IS92, 437. See also articles in The Guardian and The Church Quarterly, I8go. 
statement is this: that the great divines of the time of Elizabeth did not claim that ordination by bishops was essential to a valid commission as a minister. This is plainly the view of Hooker in his Ecclesiastical Polity. ${ }^{1}$ The broad and generous spirit which he sought to impart to the Church, would, if it had been carried out, have prevented the division of Protestant England into two hostile camps.

But in the time of James it began to be claimed, by leading clergymen, that Prelacy was essential to the existence of a church, or the validity of Christian ordinances. "They claimed," says Macaulay, "a celestial origin for the polity of the Episcopal Church, and ascribed a new dignity and importance to her services. Some practices which had been long disused, and which were commonly regarded as superstitious mummeries, were revived." ${ }^{2}$ In the time of Elizabeth, for example, the Communion table had stood almost always in the midst of the church. But in the time of Charles the First, a royal decree required its removal to the place in the nave of the church, which it had occupied before the Reformation. The priests wore the cap and the surplice during the time of the service; but they often wore the

1 Ecclesiastical Polity vii. ch. xiv. I I. Green, vol. iii. 3I.

2 Macaulay's England, vol. i. 6o. Campbell, vol. ii. 222. Green, vol. iii. 16 . 
Genevan gown in the pulpit. In the chapel of Lambeth House, the stained glass was removed from the windows, in order that there might be more light for the people to follow the lessons. The Communion table was moved into the middle of the chapel, the credence table was destroyed, the cope was no longer used as a special vestment in the Communion, and the archbishop forbore to bow at the name of Jesus. The aspect of English churches, and of English worship, in the reign of Elizabeth, says Mr. Green, "tended more and more to the model of Geneva." But under the Stuarts the forms of worship were brought nearer to the ritual of the Church of Rome. Some of the bishops, and a large number of the clergy, advocated the doctrine of the Realpresence in the Sacrament, and the practice of auricular confession, and of praying for the dead.

Last of all, the fact that the Puritans had become a leading party - perhaps a majority - in the kingdom, led them to make questions of the reform of the Church the leading questions in the Parliamentary debates. They were entirely loyal to the king; but their love of liberty, in the state as well as in the Church, their English pluck and stamina, required them to stand for the rights of the people. 


\section{XIII.}

So it came to pass that the Puritans became the leading defenders of constitutional liberty in the time of the Stuarts. They had a majority in the first Parliament of James the First, which met in 1604 . The first act of the House The First of Commons was to frame bills for Parliament of the redress of ecclesiastical grievances. ${ }^{1604 .}$

When these were rejected by the Lords, at the instigation of the king the Commons sent a very bold address to the king, in which they said, that Parliament had come together in the spirit of peace; that they desired to put an end to the dissension among the ministers, and to preserve uniformity by the abandonment of a few ceremonies of small importance, by the redress of grievances, and by training a preaching ministry. They said: "Let your Majesty be pleased to receive from your Commons in Parliament information as well of the abuses in the Church, as in the civil state and government." "Your Majesty would be misinformed, if any man should deliver that the kings of England have any absolute power in themselves, either to alter religion, or to make any laws concerning the same, otherwise than by consent of Parliament."

The king did not profit by the advice of the 
Commons, and, after some further conferences, the Parliament was adjourned. The High Church party, with the assent of the king, set aside the compromises that had been observed in the time of Elizabeth, and adopted a series of canons which increased the pressure upon the Non-Conformists. Three hundred ministers, who were unable to comply with the new demands of the Convocation, were driven from their parishes in 1605 . Ten men who had presented a petition for reform, were sent to prison, because, as the judges said, "Such things tend to sedition and rebellion." The Convocation formally asserted the divine right of kings, and the duty of passive obedience. Test oaths were imposed upon students entering the universities. The Convocation denounced as a fatal error the assertion that all power and authority are from the people. In accordance with these declarations was that of the University of Oxford, that it is never lawful for subjects to take up arms against their princes.

The king assumed the right to levy duties upon certain classes of goods without the consent of Parliament. As soon as Parliament came together, they asserted their right to determine what impositions should be made. They also asked that the ministers who had been silenced should be permitted to preach; and that the jurisdiction of Ecclesiastical Courts should be regulated by 
law. The king insisted upon his prerogative, and in I6 I I dissolved his first Parliament.

For three years, he tried the experiment of governing without a Parliament, while the people were gradually coming to the point of governing the state without a king. "A $\begin{aligned} & \text { The Second } \\ & \text { Parliament, }\end{aligned}$ people may be without a king," said a I6I4. leading member of Parliament, "but a king cannot be without a people." In I6I4, he convened his second Parliament. In this body the great Parliamentary leaders appeared, for the first time,- John Pym, Sir John Eliot, and Thomas Wentworth. This Parliament refused to vote supplies until they had attended to the public grievances. They fixed upon the abuses of the Church as the first grievance to be redressed. The king dissolved this Parliament after a session of only two months.

For the next seven years no Parliament was summoned. The king attempted to raise money by loans and benevolences. He sent letters to the wealthy land-owners, asking for money to meet the expenses of the government; but the letters were not answered. In three years only sixty thousand pounds were raised. The judges were appealed to, but in vain. The Chief Justice, Sir Edward Coke, told the king that the laws of England were the supreme rule, and that when any cause came before him he should act as it became a judge to act. He was dismissed from his office; but this only increased the difficulties of the king. 
In $162 \mathrm{I}$, a third Parliament was convened. The king forbade them to discuss matters of state, and The Third Parliament, threatened to commit to the Tower those 1621 . who opposed his demands. They replied, that the rights and privileges of Parliament are the birthright of the English people; that the making of laws and the redress of grievances are proper subjects of debate in Parliament; and that every member has, and of right ought to have, freedom of speech. The king, in his rage, sent for the Journals of the House, and tore out the pages which contained the record of

The Fourth

Parliament, this protestation, and dissolved the ParI625. liament. Three years later, he called his fourth and last Parliament, which proved to be as fearless and as far-sighted as those that had gone before. The next year, the king died, having failed in all his plans to check the rising spirit of liberty in the nation.

The great leaders during this reign were Hampden, Pym, Eliot, Coke, and Selden. They were not all Puritans; but they were agreed in demanding their rights, and the rights of the people. The Archbishop of Canterbury, in the later years of James, was Dr. George Abbott, a man of gentle spirit, and of great learning, who was disposed to favor the Puritans so far as he could without violating the laws of the Church. It was commonly believed at the time that he was more 
than half a Puritan. His name stands second among the translators of the Bible. In his time, the service in Lambeth Chapel was almost as simple as that in Presbyterian churches. He forbade the reading of the proclamation of King James, permitting sports and pastimes on the Sabbath. He refused to license the publication of a sermon in which the king's prerogative was unduly magnified; he tried to moderate the severity of the persecution of the Non-Conformists, and to secure a compromise between the parties. In this the Archbishop did not stand alone among those who were devoted to the Established Church. There was a large minority among the clergy, as well as among the laity, who, while they did not scruple to conform to the ritual of the Church, joined heartily with the Puritans in their opposition to the arbitrary measures of the Stuarts, and in their demand for liberty in the Church. It was their misfortune that they were overborne by the extreme men who had been selected to fill the more prominent positions in the Church.

\section{XIV.}

IT was during the reign of James the First that the settlement of New England was begun. The Pilgrim Fathers, and the Puritans, who laid the foundations of these States, had been trained for 
their work in the conflicts that were going on in England in the earlier part of the seventeenth century. They had seen thousands of the Protestants of France and of the Netherlands driven into exile, and they were becoming accustomed to the thought that they must cross the sea, and plant a New England in the New World. The The Thirty Thirty Years War had already begun, Years war. and the Parliament and people of England had called in vain upon the king to throw the great power of England into the scale, on the side of the struggling Protestants. But James was seeking to strengthen his dynasty by a matrimonial alliance with Spain, - the most cruel of the persecutors of the Protestants. When this plan failed, he turned to France, and entered into negotiations for the marriage of his eldest son with a French princess. But the rumor of it awakened the opposition of the Puritans. The French They knew the danger of introducing slliance. a Roman Catholic queen, with her French attendants, at such a critical time. They also resented the stipulations - to which the king had consented - of relaxing the laws against the Romanists, as the price of the alliance, because those stipulations would furnish a pretext to a foreign government to interfere in the civil affairs of England. They foresaw that the French alliance would bring into the royal family influences 
that would weaken the hold of the Reformation upon the nation. In fact, the prospects of the Protestant Reformation in Europe had never been so dark as they were in the last years of James the First.

\section{$\mathrm{XV}$.}

The Pilgrim Fathers, who began the settlement of New England in 1620, came from the northern counties of England. "They were from several villages," - says their historian, Governor Bradford, - "some in Nottingham, some in Lincoln, and some in Yorkshire, where they bordered nearest together." A number of zeal- The Pigrim ous preachers had been going about in Fathers, 1604 . these northern hamlets, teaching the people from the Word of God, and moving them to reform their lives. We are not told who these preachers were, but their success was so great that there was already a beginning of persecution. These people formed themselves into two Independent churches, which met from week to week on the Lord's day for worship. One was at Gainsborough-upon-Trent, which had as its minister John Smith, and which left the country for Amsterdam, under stress of persecution, in 1606. The other church, in which we are especially interested, was at Scrooby. It met for worship in the chapel of the old manor-house, which was 
at that time under the control of Mr. William Brewster, who was looking after the mails for the government, and who was also the agent for the Archbishop of York, for the care of the manorhouse. The place was described as a "mean townlet," and it is hardly more than that to-day. The ministers of this church were Mr. Richard Clipton - " a grave and reverend preacher who had done much good" - and Mr. John Robinson, - " a famous and worthy man," a graduate John of Corpus-Christi, in Cambridge, where Robinson. he attained a Fellowship. During the four years from 1600 to 1604 , he had been a teacher or lecturer at Norwich. He was suspended by the Bishop on account of his Puritan tendencies. He made efforts to obtain the right to preach in some chapel, or to secure the mastership in the Hospital. It was in such humble positions as these that many of the ministers who had been silenced for non-conformity continued to preach. But Robinson did not secure a chapel or a lectureship, and so he went into the north country, where he found the two Separa. tist churches. They were already enduring persecution. "Some were taken and clapped up in prisons, others had their houses beset, and watched night and day, and hardly escaped their hands; and the most were fain to fly, and leave their livelihood. Seeing themselves thus molested, 
and that there was no hope of their continuance there, by a joint consent they resolved to go into the Low Countries, where they had heard was freedom of religion for all men. So, after they had continued together about a year, and kept their meetings in one place or another, exercising the worship of God amongst themselves, notwithstanding all the diligence and malice of their adversaries, they, seeing they could no longer continue in that condition, resolved to get over into Holland as they could, which was in the year I607 and 1608." 1

These religious people were countrymen, " used to a plain country life and the innocent trade of husbandry." They were going to a strange country where they must learn a new language, and get their living they knew not how; for they were not acquainted with trades nor traffic. "But their desires were set on the ways of God," says their historian, spirit of the " and to enjoy His ordinances; and so Pilgrims. they trusted His providence. But they found the ports and havens shut against them, so that although they could not stay, yet were they not permitted to go." A large company of them purposed to sail from Boston in Lincolnshire; and they hired a ship to take them and their goods to Holland. But when they had gone on

1 Bradford's History of Plymouth Colony, chap. i. 
board, the master of the ship betrayed them to the officers who were watching for them. They were taken back to the town, rifled by the officers of much of their money and other goods, and committed to prison. After a month's imprisonment, the greater part were set at liberty; but some of the principal men were kept in prison. In the course of time they were set at liberty, and this large company of plain people managed to subsist through the winter. It is not easy to see how, for they had broken up their homes, and sold their property.

In the spring following, they made another attempt to reach Holland. They made an agreement with a Dutch shipmaster to take them to Zealand. At the appointed time the women and The Departure children with the goods were sent in for Holland. a small bark, and the men were to meet them by land. The bark arrived one day before the ship came, and ran aground in low water. While they were waiting for the tide, the ship came, and took on board a boat-load of the men who were on the shore. Before the others could get to the ship, a company of armed men with officers appeared and took them into custody, with the women and children. The Dutch shipmaster, seeing that the most of his passengers were gone, hoisted sail and went on his voyage with such passengers as he had. 
"Pitiful it was," says Bradford, "to see the heavy case of these poor women in their distress: what weeping and crying on every side, - some for their husbands that were carried away in the ship; others not knowing what should become of them and their little ones; others melted in tears, seeing their poor little ones hanging about them crying for fear and quaking with cold. Being thus apprehended, they were hurried from one place to another, and from one justice to another, until in the end they knew not what to do with them. For to imprison so many helpless women and children for no other cause but that they would go with their husbands, seemed to be unreasonable, and all would cry out of them: and to send them home again was as difficult, for they alleged (as the truth was) they had no homes to go to, for they had sold or otherwise disposed of their houses and livings. After they had been in these troubles a good while, and conveyed from one constable to another, they were glad to be rid of them upon any terms; though, in the mean time, the poor souls endured misery enough. In the end they all got over, some at one time, and some at another, and met again according to their desires, with no small rejoicing." Mr. Robinson and Mr. Brewster and the other leading men of the company remained in England to help the women and children, so that they 
came to Holland last. The whole party was gathered in Amsterdam. Such were the experiences of these plain country people who were fleeing from their native land in the years that followed the Hampden Court Conference. By such constancy in suffering they were preparing for the great mission, which was to come to them twelve years later, - to lay the foundations for a new Christian Commonwealth beyond the sea.

The next year they removed to Leyden, "a fair and beautiful city," where "they fell into such trades and employments as they best could, and at length they came to raise a competent and comfortable living with hard and continual labor." Mr. Robinson was duly chosen their pastor, and Mr. Brewster their elder. "And so they grew in knowledge and other gifts and graces of the Spirit of God, and lived together in peace and love and holiness. And many came unto them from divers parts of England, so that they grew to be a great congregation." That "fair and beautiful city" was their dwelling-place for about twelve years.

Life in The friendly Dutch people saw that Leyden. they were diligent in their callings; and they gave them their confidence and favor, and strove to get their custom, and to employ them above others in their work, on account of their honesty and diligence. The magistrates of the 
city gave this testimony of them about the time of their coming away: "These English have lived amongst us now this twelve years, and yet we have never had any suit or accusation against any of them."

In due time it became plain to these Godly people that it was expedient for them to make one more removal. They had been hospitably entertained in Holland, and had enjoyed liberty of conscience there. They had continued to worship God on the Lord's day, according to their simple Congregational way, no man forbidding them. But that was not their $\begin{gathered}\text { Reasons for the } \\ \text { removal from }\end{gathered}$ country. There was no room to establish Leyden.

a new commonwealth. Their children were not likely to continue to use the English language, nor to follow the customs of the English people. They would be likely to become mingled with the people of the land in which they dwelt. They had heard much of the unpeopled countries of America. They had a "great hope and inward zeal of laying some good foundations for the propagating and advancing the Gospel of the kingdom of Christ in those remote parts of the world; yea, though they should be but as stepping-stones unto others for preparing of so great a work." So, with much difficulty, they obtained a patent from the Virginia Company, and made preparations for their voyage. "They knew they were Pilgrims, and 
looked not much on those things, but lifted up their eyes to Heaven, their dearest country, and quieted their spirits."

\section{XVI.}

IT is not the purpose of this chapter to follow them in their voyage, or to trace the history of their settlement at Plymouth, but only to show by what experiences they were prepared for their great mission. "Through scenes of gloom and misery," says Mr. Bancroft, "the Pilgrims showed the way to an asylum for those who would go to the wilderness for liberty of conscience. Enduring every hardship themselves, they were the servants of posterity, - the benefactors of succeeding generations." "Out of small beginnings," said Governor Bradford, "great things have been produced; and as one small candle may light a thousand, so the light here kindled hath shone to many, in some sort to our whole nation."

The light did shine. There is abundant evidence that the progress of that small colony, which went to the New World in 1620 , was watched with great interest by the Puritan leaders who were engaged in the struggle for civil and religious liberty in England. "Let it not be grievous to you," wrote some of the English Puritans to the men of Plymouth, "that you have been instru- 
mental to break the ice for others. The honor shall be yours to the world's end."

The Puritans were not ready to leave the old country when the Pilgrims went, be- charles the cause they were in the midst of the con- First, 1625. test with James the First. When Charles became king, in 1625 , there were strong hopes that he would profit by the experience of his father. $\mathrm{He}$ had been popular as a prince. It was understood that he was a decided Protestant, and that counted for a great deal. It was believed that the young king, who had lived so long among the English people, would regard the will of the nation; for it was evident that England was becoming more thoroughly Puritan every year.

But, unfortunately, the Duke of Buckingham stood nearest to the king as his friend and adviser, while Bishop Laud was his chief counsellor in ecclesiastical matters. The pulpits of the Established Church resounded with denunciations of the Non-Conformists, and with the assertion of the doctrine of the divine right of kings, and of the duty of passive obedience. Montague, a chaplain at the court, advocated the doctrine of the Realpresence in the Sacrament. Dr. Mainwaring preached before the king that there was no need to ask the consent of Parliament for the imposition of taxes, and that to resist the will of the king was to incur eternal damnation. Both these 
clergymen were sent to prison by order of Parliament for their public utterances, but both were set at liberty, and made bishops by order of the king. Charles seemed only too ready to adopt the principles which the High Church clergymen were teaching. In May, he called together his first Parliament, and asked for a grant of supplies. They voted a hundred and forty thousand pounds, and then proceeded to consider the public grievances. The leading members of the House of Commons had learned from their experiences under James that the most effectual check upon the arbitrary power of the king was the control of the national treasury. They determined that no grants of money should be voted except upon condition of the redress of grievances. They made the customary grant of the duties from customs, but limited the grant to a single year, and then proceeded to consider the complaints of the people. "They saw," says Mr. Palfrey, "that the time had come to determine whether the English people should live in future under an absolute or under a limited monarchy; and they launched upon the course of measures which was to decide that momentous question." 1

Charles dissolved three Parliaments within four years. He committed Sir John Eliot to the Tower of London for his bold words in defence

1 Palfrey, vol. i. 265. 
of the rights of the people. The House of Commons refused to go on with the public business until he was set at liberty. For ten days the king obstinately refused to Eliot. release him. He finally yielded to the necessity that was upon him, but soon dissolved the Parliament. After the dissolution, Charles attempted to raise money by forced loans; but the people refused to give anything save by way of Parliament. The Chief Justice refused to recognize the legality of the taxes imposed by the authority of the king, and he was summarily dismissed from his office. John Hampden was thrown into prison, because he refused to pay money that was demanded without authority of law, in violation of Magna Charta. The third Parliament, which met in 1628 , drew up the famous Petition of Right, to which they asked the assent Petition of of the king, as the condition of the Right. grant of money. In this Petition they demanded that no taxes be hereafter levied without the consent of Parliament; that no person be fined, or imprisoned, or in any way punished, without a trial; that martial law in time of peace, and the billeting of soldiers upon the people, be discontinued; and that the rights and liberties of the people, according to the laws and statutes of the realm, be recognized by all the officers and ministers of the king; and especially that the writ of 
Habeas Corpus shall not be denied whenever the law allows it. ${ }^{1}$ To this Petition, after many evasions, the king gave his assent in the usual form : "Let right be done as is desired." The bill for subsidies was immediately passed, and the bells were rung, and the bonfires were lighted in token of the joy of the people.

But the faithless king had no intention of keeping the promises that he had given. Arbitrary arrests were still made, and taxes and customs were still levied, without authority of law. The House of Commons refused to vote further supplies until these grievances should be redressed; and when they found that the king had determined upon a dissolution, they declared, by formal resolutions, that whoever should bring in innovations in religion, or should levy subsidies not granted in Parliament, is a capital enemy to Final Decta- the kingdom, and every subject volunration of tarily complying with illegal acts and 1629. demands is a betrayer of the liberty of England, and an enemy of the same.

Thus the issue was joined between those who stood for the ancient liberties of the people, and the supporters of the arbitrary monarch. As soon as Charles had dissolved this Parliament, he entered upon that course of tyranny which, after twelve years, led to the Great Rebellion. For

1 Neal's History of the Puritans, vol. i. 287, N. Y. Edition. 
eleven years, he governed without a Parliament. The leaders of the Commons in the last Parliament were thrown into prison. Sir John Eliot, the boldest of the patriotic leaders, was subjected to an imprisonment so severe that he The Tyranny died after three years. Towards the of charles. end of his life, the king was asked to order his release for a time, in order that he might breathe the fresh air, and gain some respite from the attacks of disease. But he refused to grant even this favor. After the death of Sir Jolnn, his son requested permission to bury him in his native county; but the King replied, "Let Sir John Eliot's body be buried in the church of that parish where he died," - that is, in the prison. When the imprisoned patriots were claimed by a writ of Habeas Corpus, the Lieutenant of the Tower was forbidden to produce his prisoners in court. They were condemned to pay heavy fines, and to be imprisoned during the pleasure of the king. Large sums of money were secured for the Treasury by arbitrary fines, and by the sale of Monopolies, which had been prohibited by law since the time of Elizabeth. The customs duties were collected without authority of law. Those who protested against these illegal exactions were ruined by excessive fines. Loans were demanded in the king's name from the freeholders in every shire. By such means as these 
the annual revenue was raised from half a million to eight hundred thousand pounds; and some of the courtiers expressed the hope that "the king would never need any more Parliaments."

While the king was carrying out his plans in the government of England, Bishop Laud was transforming the English Church. First, he severed the ties which had united the Reformed Churches of the continent with the Church of England. He held that ordination by bishops was essential to a valid ministry, and that the Reformed Churches of Switzerland and of Germany were not true Churches. The freedom of worship, which had been allowed to the Protestant refugees from the Low Countries and from France, was withdrawn, and those exiles were required to conform to the ritual of the Church of England, or to flee from the kingdom.

In 1633, Laud became Archbishop of Canterbury. He began at once to use the great power of the court of High Commission to reduce the Puritan ministers to submission. The offensive ceremonies were strictly insisted upon. Every minister who refused to conform to them was silenced. The lectureships founded in towns, which had been the refuge of the Puritan preachers after they were silenced, were suppressed by the Primate. $\mathrm{He}$ also withdrew the privilege of keeping chaplains, because many 
wealthy persons in the country had appointed the suspended ministers as their preachers. The Puritans had been buying up the appropriations of livings in certain parishes, and they attempted to secure, through feoffees, the right to appoint their own ministers to the parishes of which they were patrons; but the Archbishop, by a stretch of power, put an end to these feoffments. The people had become very fond of the small pocket Bibles, with marginal notes, which had been imported from Geneva; but these marginal notes were obnoxious to the Archbishop, and so the importation of these Bibles was prohibited. Hundreds of laymen were excommunicated for refusing to kneel when they received the Communion. The English people, under the influence of the Puritans, had been accustomed to keep Sunday very strictly, as they do to this day. But the Archbishop ordered every minister to read from the pulpit a declaration in favor of Sunday sports. Large numbers were deprived of their livings, and silenced, for refusing to read such a declaration. One minister read the declaration to his people, and then read the Ten Commandments, and said: "You have heard the commands of man, and the commands of God. Obey which you please."

The progress toward the doctrines and the ceremonies of the Roman Catholic Church was 
rapid. It was this that touched the people most deeply. "The Gospel," said Sir John Eliot, "is that truth in which this kingdom has been happy through a long and rare prosperity." "Whenever mention is made of danger to religion," said another, "and of the increase of Popery, their affections are much stirred." The Archbishop was not a Romanist; but he aimed at restoring the pomp and splendor of Romanism in public worship, and at bringing the Church into closer relations with Rome. He avowed his preference for a celibate clergy. Some of the bishops advo. cated auricular confession, and prayers for the dead. The doctrines of the Church of Rome were preached in the pulpits from which the most learned and devout ministers in the land had Extreme been ejected. Laud was backed by the Measures of power of the king, who was determined
the Archbishop. to root out Puritanism from the kingdom, while the prelates were preaching passive obedience, and turning religion into a systematic attack on English liberty. In the pages of Neal, one may still find the record of the petty persecution which was carried into the most distant and obscure parishes of the kingdom. Every minister who hesitated to conform to any of the requirements of the Established Church, in regard to vestments, or ceremonies, or the manner of observing Sunday, was pursued with unrelenting 
vigilance. It was not enough to deprive him of his living. He must not preach in the fields, or in a private house. He must not teach a school, or take private pupils. He must not practise medicine, or engage in business. He was liable to arrest for his non-conformity, and to heavy fines and imprisonment. Those ministers who became the first pastors of the churches in New England, had almost all of them been silenced for non-conformity. Several of them had been imprisoned. Some of the most eminent of them were fleeing from the officers when they took passage for America.

There is no more graphic picture of the condition of England at that time than the few lines of "Lycidas," one of the early poems milton's of that foremost Englishman of his age, "Lycidas." John Milton. In his tender lament at the too early death of his friend Lycidas, he contrasts his pure and beautiful life with the lives of those who

$$
\text { "for their bellies' sake, }
$$

Creep, and intrude, and climb into the fold.

Of other care they little reckoning make,

Than how to scramble at the shearer's feast,

And shove away the worthy bidden guest :

Blind mouths! that scarce themselves know how to hold A sheep hook."

The hungry sheep look up, and are not fed;" while the "grim wolf" of Rome, 


$$
\text { "with privy paw, }
$$

Daily devours apace, and nothing said: But that two-handed engine at the door Stands ready to smite once, and smite no more."

Milton says of himself, that when he came to some maturity of years, he perceived "that tyranny had invaded the Church, and that he who milton's Non- would take orders must subscribe slave, conformity. and take an oath withal," so that he thought it better to give up the sacred office, rather than to obtain it by "servitude and forswearing." Milton was but one of many of the cultured and devout young men from the universities who found themselves shut out from the National Church by its lack of toleration.

\section{XVII.}

That which is called the bigotry of the Puritans was the result of such experiences as these. Their spirit was that of soldiers in an enemy's country, encompassed by adroit and treacherous enemies, and standing for their rights as Englishmen and Protestant Christians. It may be that The Bigotry men who have to contend with such kings of the as the Stuarts are likely to become narrow. Puritans. In the conflict for the right to worship according to their consciences, such men would be likely to develop the sterner virtues. With a 
great price, they obtained the freedom which we enjoy, and so long as the conflict lasted, they belonged to the Church militant. That which we call their narrowness was the result of their vigilance. They crossed the ocean to be free from the power of the prelates and of Rome, and it is not surprising that they claimed the right to exclude from their new plantations those who seemed to them to be unfriendly to their great purpose. We who have entered into the heritage which they gained, have little right to judge them by the standards of an age of peace and luxury.

\section{XVIII.}

The great Puritan migration to New England began in the darkest hour of the struggle for constitutional and religious liberty. King Charles had determined to govern without a Parliament, in defiance of the will of the people. There seemed to be no available means of carrying out the will of the people, when it was resisted by the power of the king. It rested with him to summon a Parliament when he pleased, and he could dissolve it when it interfered with his plans. By a careful economy, and by maintaining peace with foreign powers, Charles had reduced the expenses of the government to the smallest practicable sum, and this he succeeded in obtaining by means 
which were indeed illegal, but which it was not easy to interrupt. The judges held their offices Means of sus during the pleasure of the king, and, taining the
Tyranny of the King. servient to his will. The moral power of the Established Church was used by the Primate to sustain the personal government.

When Charles was dissolving his third Parliament, he granted the Charter which established the

The SettleColony of Massachusetts. Men thought ment of Mas- they saw the hand of Providence pointing
sachusetts.

them to the lands beyond the sea as the place where they could realize their ideal of a free Church in a free state. The Puritans did not all give up the contest. The great majority remained to continue the struggle that was to result in the overthrow of the personal government and the vindication of the rights of the people. It is an interesting fact, however, that at one time even John Hampden purchased a tract of land in New England, with a view to leading a colony there. There is a tradition that Oliver Cromwell was only prevented from going by a royal embargo. The Puritan Lord Warwick bought a tract of land in the Connecticut valley, and Lord Saye and Sele and Lord Brooke at one time expected to transport themselves to Massachusetts. It was better, however, that these leaders who were engaged in the struggle in England 
remained behind, and that younger men, who were not needed at home, led the colony across the sea. Those who went away were not inferior to those who stayed behind. Though separated by the breadth of the Atlantic, the two sections of the Puritan party continued in full sympathy with each other, each section carrying out, in its own way, and according to its environment, the principles which they held in common.

The plan for emigration had been under discussion in the Puritan families for a long time. Sir John Eliot, while a prisoner in the Tower, corresponded with John Hampden about it. ${ }^{1}$ A notable "agreement" was entered into at Cambridge, in I629, for the settlement of New England, signed by John Winthrop, William Pynchon, Isaac Johnson, Thomas Dudley, and others. The emigration was on a large scale. Endicott went to Salem in 1628 , with forty or fifty persons; four hundred came with Higginson in 1629 ; eight hundred arrived with Governor Winthrop in 1630. $\mathrm{Up}$ to the time of the meeting of the Long Parliament, in 1640 , the average number of emigrants was about two thousand a year. After the meeting of the Long Parliament, very few came over, as the Puritans in England had gained a position which gave them the assurance of success.

${ }^{1}$ Life of Winthrop. 


\section{XIX.}

The struggle in England had been going on through all those years. The most important events were connected with the efforts of the king to collect money without the authority of Parliament. The law officers of the crown had found The ship- precedents for collecting money from Money. the port towns to equip ships for the navy. Writs were issued, and the money was paid by the towns on the coast. But, it was argued, the obligation to support the royal navy rests as much upon the people who live away from the sea, as upon those in the port towns. So that it was claimed that all the people of England were bound to pay ship-money. A quarter of a million a year was collected in this way. But, the ministers of the king reasoned, if the people of England are bound to pay ship-money to support the navy, they are under an equal obligation to pay ship-money to support the army, and to meet all the expenses of the government. If such claims as these were allowed, it was plain that there would be no need of the authority of Parliament for the collection of the revenue.

It was John Hampden who brought the question before the courts. The trial of this case, in 1637 , attracted the attention of the whole country. It 
lasted twelve days. In the end, seven of the twelve judges decided that no statute prohibiting arbitrary taxation could be pleaded against the king's will. "Rex is lex," said the judges. "Acts of Parliament to take away the king's royal power in the defence of his kingdom are void." The king and his courtiers exulted over the decision; but the people of England were aroused to a sense of the danger to their liberties. Hampden had gained his purpose by the publicity of the proceedings; and from that day the people never forgot the lesson of that historic trial. The struggle began in Scotland. The Scottish people renewed their covenant, and gathered an army to resist the efforts of Charles to introduce the Episcopal forms of worship into their churches. The Scottish war made it necessary for the king to summon a Parliament, which met in April, i640. The king asked for grants of money to put down the Scottish rebellion. But the Commons declared that no subsidy could be granted till security was had for religion, and the rights of the people. Charles dissolved the Parliament after a session of three weeks. This dissolution added to the determination of the people. The king found it impossible by any expedients to raise money to meet the expenses of the war, and before the year ended he was forced to summon another Parliament. While the elections were pending, Hampden and Pym 
rode together through the counties to rouse the people to a sense of the crisis which was upon them. When the Houses came together, the first

The Long week was spent in receiving petitions Parliament. of grievances, which came pouring in from every county and borough. A list of the officers, who had executed the illegal orders of the king, was prepared. The oppression and persecution of Laud and his instruments were passed in review. Strafford was impeached and sent to the Tower. The Archbishop followed him soon after. The Puritans whose ears had been cropped off, and who had been sentenced to imprisonment for life, were set at liberty, and were received in London with great honor, as the martyrs of liberty. The House of Commons declared the collection of ship-money illegal, and passed a statute which put a final end to the claim of a right to impose taxes of any sort without the consent of Parliament. Another act required the assembly of Parliament once in three years, and made it the duty of the returning officers to proceed with the elections if the king should fail to summon them.

A Committee of Religion was appointed to consider the state of the Church, and to free it from the innovations which had been made by Laud and his coadjutors. But the great majority of this Parliament, in its best days, was opposed 
to any change in the constitution of the Church. They set themselves to restore it to its state under Elizabeth, and to put an end to the persecution of the Non-Conformists.

We have reached the point in the history when the emigration to New England came to an end. The direct influence of the English Puritans in moulding the character of our Puritan forefathers lasted only so long as the stream of emigration continued to flow toward the Colonies. It is not necessary for the purpose of this book to follow it further. The two great objects for which the Puritans had been contending seemed to be within reach when the Long Parliament met at Westminster. The plans of Charles had broken down, and a personal government, without the control of Parliament, was found to be impossible. The National Church was to be henceforth a Protestant Church, because the nation had become thoroughly Protestant. If the English Puritans had been content to secure these two capital objects, - a limited monarchy, and a Protestant Church under Episcopal forms of government and of worship, - they would probably have held the control of England for an indefinite period. But unfortunately the great leaders of the party, Eliot, Coke, Hampden, and Pym, did not live to guide its policy when its success was assured. New leaders gave a new direction to its action. The 
attempt was made to set aside Episcopacy and Monarchy, both of which were firmly rooted in the traditions of the people. The failure of the policy of the new leaders to establish a republican Commonwealth, and to make Presbyterianism or Independency the State Church, would have been foreseen by such statesmen as John Hampden, and John Pym. The restoration of the Monarchy, and of the Episcopal Church only hindered for a few years the success of those principles of constitutional liberty and of religious reform for which the Puritans had been contending so long.

\section{XX.}

A Few words should be added in respect to the quality and the value of the Puritan party in England. We should, first of all, acknowledge its limitations. They had the faults of their age. The sixteenth and seventeenth centuries were very far behind the nineteenth. Our goodly heritage has come to us as the result of their fidelity to the principles of liberty, as they were able to apprehend them. It must be admitted also that there was a certain insular narrowness about the English Puritans. They were not as tolerant as the Dutch Protestants of the sixteenth century. William the Silent was in many ways a more admirable character than Oliver Cromwell. 
A republic was possible in the Low Countries, while the English Commonwealth was a failure. The Pilgrims went to Holland because they had heard that in that country "there was freedom of religion for all men." The Puritans were never as tolerant as that.

On the other hand, the Puritans were the advanced Liberals of their time in England. They were, first of all, Protestants in their religion and Calvinists in their theology, and they were therefore the champions The Puritan Spirit and Character. of liberty in the Church and in the state. All their tendencies led them to claim their rights as Englishmen under the ancient laws of the realm. They stood for Magna Charta. They formulated the Petition of Right. They combined to resist the attacks upon the rights of the people.

No greater wrong has been done to the Puritans than by the assumption that they were, as a class, rude and ungraceful in their ways of living. Their Manners living. There was a time, after they and Domestic had gained political power, when large numbers of selfish and insincere men joined them, and when the Puritan character degenerated. There were perhaps hypocrites among them when they had within their gift the highest honors of the Commonwealth. These men exaggerated their peculiarities, and brought them into contempt. But the Puritans of the age of 
Elizabeth, and of James and Charles, were genuine patriots, and their lives were as gentle as they were heroic. "The Puritanism of the first forty years of the seventeenth century," says Mr. Palfrey, "was not tainted with degrading or ungraceful associations of any sort. The rank, the wealth, the chivalry, the genius, the learning, the accomplishments, the social refinements, and elegance of the time were largely represented in its ranks. The statesmen of the first period of the Long Parliament had been bred in the luxury of the landed aristocracy of the realm. The Parliamentary General, Essex, was a man with every grace of person, mind, and culture, fitted to be the ornament of a splendid court. John Milton, the Latin Secretary of Cromwell, who was equal to the foremost of mankind in genius and learning, was skilled in all manly exercises, and proficient in the lighter accomplishments, beyond any other Englishman of his day. There was no better swordsman or amateur musician than he; and his portraits exhibit him with locks as flowing as Prince Rupert's. John Owen, the great theologian of the Puritans, was considered in his time something of a coxcomb." 1 There are no more tender or graceful letters in our literature than those of John Winthrop to his wife. The life of Colonel Hutchinson, written by his widow, gives

1 Palfrey, i. 279--28I. 
a most attractive picture of a Puritan family at that time. She divells on his personal beauty, and on his love of music, "often diverting himself with a viol, on which he played masterly."

Nor did the Puritans of that earlier time break with the harmless gayeties of the world about them. They entered with zest into the sports of English country life. They were not iconoclasts until they were convinced that the High Church party were making use of music and art to divert men from the true religious life. That which we call the sternness of the Puritan spirit was the result, in large part, of persecution and of the struggle to maintain the truth.

The Puritans were the friends of learning in their time. A large number of them were graduates from Cambridge or Oxford. They made some noble contributions to English literature. A Puritan was the first Protestant founder of a college in an English university. A graduate from a Puritan college in Cambridge was the founder of Harvard University. The Puritans had a fair share of the learning and eloquence of their times.

We do well to remember that the great Puritan migration to New England took place in the best period of Puritanism, before the party had been weakened by those who came to it after its victory had been won. Our forefathers 
brought to New England the best that the Old England had to give.

If we inquire what influences this great party has left with the English-speaking races, the

Permanent Influence of the Puritans. answer will be: Free governments, by the people, and for the people, on both sides of the Atlantic; a free press; an enlightened public opinion, which controls princes and Cabinets; free public schools open to the children of the people; a nobler Christian manhood; a fuller comprehension of the religion of Christ, which brings help and comfort to the poor, which brings liberty to the slaves as those redeemed by the Saviour of the world; the separation of Church and state; the equality of all branches of the Church before the law; freedom within the Church, whether it be Prelatical or Presbyterian or Congregational; a quiet Sunday, with its opportunities for the culture of the spiritual nature; and a free pulpit, in sympathy with all sorts and conditions of men; preaching in pagan lands, and in those that are Christian; the Gospel for all such as labor and are heavy laden. 


\section{II.}

The Pilgrim and the Puritan: Which? 


\section{The Pilgrim and the Puritan:}

\section{Which?}

THE history of the Puritan party in England 1 prepares us to appreciate the early settlers of New England. That strong and peculiar type of men had been developed by the experiences of three generations in the Mother Country. They brought with them the principles for which they had been struggling. They came to the New World because they hoped to lay the foundations of a free state, and a free Protestant Church such as they had tried to develop in the land of their fathers. The success of the earlier English colonies on this side of the Atlantic had not been so great as to awaken any enthusiasm for emigration. There had been severe privations, and some disastrous failures. The evidence is conclusive that our forefathers came to New England not as adventurers, but, as the friends of liberty and of the Protestant religion, to found a state in which they could work out the principles for which they had been contending, and which they had come to believe could not be developed in the Old World. 
We shall do well to study, first of all, the characteristics of the two earliest colonies. For The Two it is well known that the Province of Colonies.

Massachusetts, which was constituted in the year 1692, was made up from two original colonies, - the Plymouth Colony, or, as we say, the Old Colony; and the Colony of Massachusetts Bay. We have already seen that the two colonies were settled at different times, by different classes of people. The Pilgrims had come from their life in Holland, where the influence of William the Silent had given a free and tolerant spirit to the earnest Protestants who had stood heroically against the armies of Spain. They could not forget the country where they had found refuge from persecution. They were the disciples of Robert Browne, and they had founded a Separatist Church in the new settlement. The Puritans were fresh from the great national contest for their rights as Englishmen under Magna Charta, in the times of Charles the First and Bishop Laud. They brought with them the principles of Sir John Eliot, John Hampden, and John Pym. They had a great dread of Popery, and they believed the Church of England was relapsing into the superstitions of Romanism.

Each Colony was developing its political and religious institutions in its own way. In many 
respects the two colonies were similar, in other respects they were unlike. It was with them much as it had been with the Republics of Greece in the best periods of Grecian history. The differences between them - small as well as great - were continued from one generation to another. If the two colonies had not been welded together by the imperial mandate from England, it is very likely that the differences between them would have continued, and perhaps become more striking, just as the differences between Athens and Sparta and Corinth did.

We shall come to a closer study of these two colonies, as we consider the question: Which has had most to do in moulding the people of New England?

\section{I.}

THE earlier historians usually gave the precedence to the Puritans. Even so recent a writer as Mr. Palfrey gives much the larger The Earlier space to the annals of the younger Historians. colony. Plymouth occupies quite a subordinate place in his volumes. But in later times there has been a higher estimate of the character and influence of the Pilgrims. Dr. Leonard Bacon, for example, wrote of them as though almost everything that is excellent in the New England character had been derived from them. He has been 
followed by a number of more recent authors, so that it has become the fashion to ascribe almost every excellence of our people to those who came over in the Mayflower. New England families are eager to trace their lineage back to the Pilgrim Fathers. A great many churches have been named from the Pilgrims, few, in comparison, from the Puritans.

\section{II.}

The Pilgrims began their settlement at Plymouth in 1620 . So that theirs was properly Difference in called the Old Colony. The Puritans Date. began their colony at Salem eight years later; and as their settlements extended around Massachusetts Bay, the Colony was called the Colony of Massachusetts Bay. In a new country the advantage of a few years in residence counts for much. The Pilgrims had a Colony well organized and governed according to democratic principles, and a Church organized after the Congregational way before the Puritans came. It may be that the Puritans would have come to America if the Pilgrims had not been already settled at Plymouth; but it is certain that the Puritans were more inclined to make the venture, from the fact that a Colony of devout Protestant Englishmen had already gained a 
foothold here. The Puritans naturally looked to the Colony at Plymouth for models in the organization of their State, and of their churches.

\section{III.}

THE pioneers in these two colonies differed in some important respects in their views of the Church. The Pilgrims had been, for many years before they came to Ply- and Inon-conmouth, Separatists. The Puritans had formists. no scruples about their connection with the Protestant Church established in England. They could continue in its worship and discipline with good consciences, provided it was faithful to the Protestant Reformation. It has been abundantly shown that their objection was not to the use of the Liturgy in public worship, nor to prelatical government. They objected to certain teachings of the Book of Common Prayer then in use, and to certain forms and ceremonies which, as they believed, tended toward the superstitions of the Church of Rome. The Puritans therefore, so long as they remained in England, claimed their rights as members of the National Church. They refused to conform to practices which they regarded as evil, and claimed the right to worship in the churches of the establishment, and to continue members of the National Church, without 
conforming to its objectionable practices. Several of the men who came with Governor Winthrop, in 1630 , had been church wardens in England. Some of them went back to the Church of England when they returned to the Old Country to spend their declining years. It is related that when the ship which carried Mr. Higginson to Salem came to Land's End, he called the passengers to take a last view of England, and said: "We will not say as the Separatists were wont to say, Farewell, Babylon, farewell, Rome; but we will say, Farewell, dear England, farewell, the Church of God in England. We do not go to New England as Separatists from the Church of England, though we cannot but separate from the corruptions of it; but we go to practise the positive part of Church reformation, and to propagate the Gospel in America." 1

When Governor Winthrop was setting out for America with his company, they issued an address to their countrymen, which was dated April 7, 1630, in which they said: "We esteem it an honor to call the Church of England our dear Mother, and cannot part from our native country without much sadness of heart, and many tears in our eyes. . . . We bless God for the parentage and education as members of the same body, and shall always rejoice

${ }^{1}$ Genesis of the New England Churches, Dr. Leonard Bacon, 467. 
in her good. . . . We wish our heads and hearts may be fountains of tears for your everlasting welfare, when we shall be in our poor cottages in the wilderness. ... And so, commending you to the grace of God in Christ, we shall ever remain your assured friends and brethren." ${ }^{1}$ It is plain from these words, which were probably written by the Reverend John White, the Puritan rector of Trinity Church in Dorchester, that the Puritans were much less severe in their judgments of the English Church, - much more charitable in these respects, - than the Pilgrims.

\section{IV.}

IT was not alone in their relations to the Church of England that the Pilgrims differed from the Puritans. The Pilgrims were, for the most part, people in humble stations in life. of the Pilgrims Governor Bradford says, "they were in England. not acquainted with trades, nor traffic, but had been used to a plain country life, and the innocent trade of husbandry." Mr. Palfrey speaks of them as " north country peasants;" and he states that it is not known to this day from what English homes they came. ${ }^{2}$ They were people of simple faith,

${ }^{1}$ Quoted by Dr. Twitchell in his Life of Governor Winthrop, 53-54. Also in Palfrey, vol. i. 312.

2 Young's Chronicles, 25. Palfrey, vol. i. 139, I60. 
ready to suffer the loss of all things for conscience's sake. When they came to Leyden, they fell into such trades and employments as they best could. Some were registered as silk-workers, some as wool-carders, fustian-makers; three were printers, one a mason, one a carpenter, one a tailor, one a smith, and five were merchants.

I do not forget by any means the eminent men who were the leaders of the Plymouth Colony: the excellent Governor Carver; Governor Bradford, the historian of the Colony, and for thirty years its enterprising and sagacious chief magistate; Governor Winslow, descended from an ancient English family, a gentleman of consummate address, a born diplomatist; and Elder Brewster, a scholar and courtier in earlier life, and later the beloved ruling Elder of the Church, and for the many years while the people were without a minister, the religious teacher of the congregation.

On the other hand, the Puritans who came to Massachusetts were, for the most part, persons in comfortable circumstances in life, of good education, and with good social connections in England.

Social Position of the Puritans.

"The principal planters of Massachusetts," says Dr. Bacon, "were English country gentlemen of no inconsiderable fortunes, of enlarged understandings, improved by liberal education." 1 The great Puritan party

1 Genesis of New England Churches, 229, 230. 
of England moulded the public opinion of that country, for the first half of the seventeenth century. Those who came to New England were fitted by their abilities and training to be the founders of States. An unusual proportion of them were graduates from the English universities. Others who were not graduates were well read in history and literature, and in theology. Their ministers were the equals in ability and in culture of the clergymen who remained in the National Church.

\section{V.}

IT will help us to understand the two colonies, if we compare them with respect to the leading objects of their founders. The Pilgrims came to these shores, not from the Mother Country, but from Holland. They were already exiles. They came to the wilderness as a place of refuge. They were already a people without a country.

Their condition in Holland had been a hard one; so hard that they were glad

Colony. to go from it into the New World. They were especially anxious to find a place where they could bring up their children to good habits, and where they would be likely to use the English language, and to keep their connection with the English nation. They had also very much at heart the conversion of the pagan Indians to the Christian faith. 
The plans of the Puritans were much more comprehensive. They came to found a New

Objects of the Puritan Colony.

England because the Old England seemed to have lost its liberties, and to lie helpless at the feet of Charles the First. They came here as the representatives of the Puritan party, - a party which included at that time a majority of the English people. It does not appear from their history that religious motives had less influence with the Puritans than with the Pilgrims. But the Puritans had, in addition to their religious interests, certain political plans which they never lost sight of. There were great statesmen among them, and great theologians. That portion of this party which settled Massachusetts was in sympathy with the great Puritan leaders in England. They regarded themselves as the pioneers of a movement which was likely to transfer a large part of the nation to the New World. They had suffered for many years for their devotion to liberty and to the Protestant religion in England ; and they purposed to found a Colony in which they, and those who should join them, would be free according to the ancient charters and statutes of England. It was not their purpose to open their Colony to people of different views from their own, for the reason that they were yet weak and comparatively few in number, and they could not tell what would be 
the result of opening their doors to all comers. They were going into the wilderness to enjoy peace and freedom; and they did not dare run the risk of losing the objects for which they had expatriated themselves, by admitting people of all faiths, and of all political views. They would found a Puritan state for the oppressed Puritans; and they claimed the right to send away any persons who seemed to them likely to disturb the peace and unity of the Colony.

In the earlier years of their history there was a prospect that a large proportion of the English Puritans would be compelled to leave England for America, just as a large proportion of the French Huguenots had been compelled to leave France. They were as resolute as Cromwell's Ironsides to protect the asylum which they had founded. Their plans were carefully laid. When there was a prospect that King Charles would try to compel them to submit to unjust demands, they proceeded to build fortifications in Boston Harbor, and to arm and discipline the militia, so as to be prepared to resist any attempts to subjugate them. The Spirit of 1776 had been developed among the Massachusetts Puritans more than a hundred years before that date. They were bold, partly because they were men of courage as well as of faith, and partly because they had back of them a numerous and powerful party at home. 


\section{VI.}

IN respect to the form of organization for the churches, the influence of the Pilgrims was the leading influence. They had a church organized after the Congregational way before they came from Leyden. Their pastor, John Robinson, had given them clear and decided views in regard to the pattern of the Church which the New Testament furnishes. It had been agreed that although the Pastor and a large part of the members were to remain in Holland, those who went to America were to constitute an Independent Church. The Pilgrim Church at Plymouth was an independent branch of the church in Leyden. When the Puritans began their Colony this Pilgrim Church had been in regular existence a number of years.

So far as can be known, the Puritans had no definite plans for the organization of the Church when they landed. It is as clear as anything else in their history that they had continued up to that time members of the Church of England. Their

The Puritan Views of the Church. ministers had been ordained as ministers in the Episcopal Church, and all their ministry had been in that church. The Puritans had decided objections to the Separatist Churches, and had been unfriendly to the Pilgrims because they had broken away entirely from the 
National Church. Their natural affiliation as Protestants and Non-Conformists was with the Reformed Churches of Geneva, and of France and Scotland. The connections between the English Puritans and the churches of Geneva had been very close for many years. If they were to break away from the Church of England it was the most natural thing in the world for them to follow the method of almost all the Protestant churches, except the Church of England, and organize according to some of the Presbyterian models. Their leading men were in correspondence with the leading Calvinistic ministers on the continent, and they were familiar with the practical working of their churches.

But the Puritans were hardly an organized Colony before they consulted the Pilgrims in regard to the best way of forming a church. ${ }^{1}$ Their bitter experiences in the English Church had prepared them to look with more favor upon the non-prelatical churches. When the conciliatory proposals of the Millenary Petition were rejected, and when the whole power of the Established Church was used to "make them conform, or to harry them out of the land," and when, for many years, they saw their national church moving toward the practices and the doctrines of the

1 Mass. Hist. Collections, iii. 65, 75. Young's Chronicles, 386. Winslow's Brief Narrative. 
Romanists, their opinions were gradually modified in respect to the forms of worship and the modes of government in that Church. So that the Puritans, who were entirely loyal to the Episcopal Church when James the First became King of England, were prepared to look with favor upon a much simpler organization when they came to New England. The fact that they had left behind the institutions of the Old Country, and that they were entirely free to carry out their own ideas, had much to do with the change. The most conservative people become progressive in a new country.

But there is decisive evidence that they were guided by the teachings and the experiences of the men of Plymouth. Governor Winslow, for Reasons why example, says that some of the chief of they Organized the Puritans advised with us in respect churches. to a right way of worship, and desired to know whereupon our practice was grounded. "We accordingly showed them," he says, "the primitive practice, taken out of the Acts of the Apostles, and the Epistles written to the several churches by the said Apostles, together with the Commandments of Christ the Lord in the Gospel, and other our warrant for every particular we did, from the book of God." 1 Endicott, writing to Governor Bradford from Salem, in 1629 , thanks him for sending Dr. Fuller to them. He says that he has

1 Young's Chronicles, 386. Walker's Creeds and Platforms. 
been satisfied by Dr. Fuller in regard to the outward form of God's worship. This Dr. Fuller was a deacon of the church at Plymouth. During the winter of $1628-9$ there was a serious epidemic among the settlers at Salem, and Gover- Dea. samuel nor Endicott sent a messenger to ask Fuller, the that Dr. Fuller might be sent to their Physician. aid. He came at their call, and remained at Salem until the sickness abated. He was the guest of Governor Endicott; and " they had much conversation about what had been going on at Plymouth during the eight years since its settlement." Dr. Fuller explained their methods of procedure in civil matters, and also in church matters; and Governor Endicott accepted his views. This was before the organization of the first church in the Massachusetts Colony. In the month of June following this visit of Dr. Fuller, three ships landed at Salem, bringing a large number of passengers. On the 6th of August of that year, the first church was formed. A small number of the people at Salem desired to use the Book of Common Prayer ; but a great majority preferred to follow the example of the Pilgrim Church at Plymouth, and organize after the Congregational way. How much the influence of Governor Bradford and of Dr. Fuller had to do with this decision may never be known. Undoubtedly they were among the instruments in the change that took place among 
the Puritans. For it is plain that there was a decided change of sentiment among them. When the first church among the Puritans was formed, August 6, 1629, it was almost an exact copy of the Pilgrim Church in Plymouth." "We have come away from the Common Prayer, and ceremonies in our native land," they said, "where we suffered much for non-conformity. In this place of liberty we cannot use them. Their imposition would be a sinful violation of the worship of God." "We separate not from the Church of England, but from its corruptions."

The example of the church in Salem was followed by the churches that were formed within a year or two in Charlestown and in Boston. The precedent was thus firmly established, and the churches of the Pilgrims and those of the Puritans were organized as Independent or Congregational Churches.

\section{VII.}

In respect to the political and social institutions of Massachusetts, the influence of the Old Colony was very great. The frame of government in the Pilgrim Colony was as near as practicable a pure Democracy. The suffrage was conferred by

${ }^{1}$ Dr. Tarbox, in Collections of the Old Colony Historical Society, I 878,4 I-50. Three Episodes of Massachusetts History, Charles F. Adams, I 892 . 
the freemen upon all whom they deemed worthy of it. There was no religious test. The Governor was chosen by general suffrage. The citizens also elected a Council of Five to advise and assist the Governor. The

Political and Social Institutions. whole body of adult male inhabitants constituted the Legislature. ${ }^{1}$ There could be no law or tax without the consent of the freemen. The general meeting of the freemen of the Colony was like a modern town-meeting. As population increased, a representative system became necessary, and each town in the Colony sent its representatives to the House of Delegates. Their social institutions were also very simple. There Republic. were few traces of an aristocracy. The people of the Old Colony lived together on terms of Christian equality.

The influence of Holland appears in these institutions of the Pilgrim Fathers. Their twelve years among those stanch defenders of liberty had given them new ideas in regard to the right of the people to direct the course of government, and in regard to the right of suffrage, and the organization of the town, and in respect to legislation, and to common schools for the people. They introduced a number of principles which had not at that time been accepted in England, when they laid the foundations of the NEW England.

1 Bancroft, i. 25 I. 
In the Massachusetts Colony, however, we find that they copied the institutions of the Mother

The Puritan Republic.

Country, and adopted many of its social distinctions. The right of suffrage was restricted to the members of the churches of the Colony, just as in England the suffrage was limited to communicants in the Church of England. The churches which were recognized by law, that is, the Independent Congregational Churches, were supported by a tax upon all the inhabitants, just as in England the Established Church was supported by rates upon all property of the people of the parish. The Governor and the Assistants were chosen by the votes of the freemen of the Colony. The Deputies were elected by the freemen in each town. It was seriously proposed that members of the Court of Assistants should hold office for life, or until removed for cause. John Cotton preached before the General Court, in I634, "that a magistrate ought not to be turned into the condition of a private man without just cause." It was at one time proposed that a number of the great Puritan noblemen should settle in Massachusetts, with the understanding that they should have a permanent place in the government, and that their rank should be hereditary. The fact that these proposals were made shows one of the tendencies of the times. But these tendencies were not permitted to control the colony. The Demo- 
cratic principles of the people asserted themselves even in the earlier years. The eminent public men, like Governor Winthrop, learned from experience that they had no secure tenure of official position, except so long as they carried out the will of those who had elected them. It is an error to suppose that either the ministers, or the more prominent citizens, had the control of the Colony. There were instances, even in the early years, when these natural leaders were out-voted and set aside in a popular election.

\section{VIII.}

IN respect to numbers and wealth the two colonies were very unlike. When the Old Colony was four years old, it contained only thirty- Numbers and two cabins, inhabited by one hundred wealth. and eighty persons. Six years later, it numbered three hundred. Five years after this, when the Colony was fifteen years old, it had only five hundred people. After seventy years, it had only eight thousand people. So slow was its growth. And yet that small Colony has exerted an influence out of all proportion to its numbers. Its history reads like a work of the imagina- $\begin{gathered}\text { Weakness } \\ \text { of the } 01 \mathrm{~d}\end{gathered}$ tion, rather than a recital of events in colony. this prosaic world. There is a certain poetic quality about it which makes its simple annals 
very fascinating. The sublime faith of its people, their patience under adversity, their boldness in crossing the sea with limited numbers and scanty resources, the motives which inspired the enterprise, - " that we might enjoy liberty of conscience" and "keep our own language and the name of Englishmen," and "train our children as we were trained," and "enlarge the Church of Christ," 1 - and besides all this, their gentleness and charity toward those who differed with them, their freedom from the spirit of persecution, their tolerance in a century of intolerance, - all these have won for them the sympathy and the admiration of good men everywhere.

So much as this may be fairly and heartily conceded to the Pilgrim Fathers. And yet the clearheaded student of New England history will find, as he compares the two colonies, that, after all, the elements of vigorous growth and permanent influence were in the Puritan Colony, rather than in the Colony at Plymouth. He will look first at the numbers who came to the Bay Colony. The number of Pilgrims in Holland when the Mayflower sailed for America was not much more than three hundred. Less than half of these sailed in the Mayflower on its first voyage. Those who remained behind were a small company from which to recruit a colony. But when

1 Winslow's Narrative in Young's Chronicles, 38I. 
the Puritans crossed the sea the larger part of England was Puritan. Twelve years after the beginning of the Puritan settlements, vigorous the Colony had more than twenty thou- Growth of the sand people. In that time they had colony. planted fifty towns and villages, built thirty or forty churches and a larger number of ministers' houses, a castle, forts, roads, and a prison, all at their own charges. They were living in comfortable houses, with gardens, orchards, cornfields, and well-fenced fields. ${ }^{1}$ They had founded Harvard College, and they were taxing themselves for its support. Colonies had already gone out from them to begin settlements on the Connecticut River, at Springfield, and at Hartford, and also at New Haven, and in Rhode Island, and New Hampshire. This is a marvellous record of growth for a Colony separated from the Mother Country by the width of the Atlantic. It indicates the singular energy and enterprise of the Puritans. It is from such elements that colonies grow into a nation.

\section{IX.}

THis is the outward material growth. But the contrast was quite as marked in the intellectual spirit of the two colonies. Let us take as the

1 Wonder Working Providence, ch. xiv. New England's First Fruits. 
first illustration of this contrast, the religious teachers of the people in the two colonies. DurThe Intellec ing the first fifty years of the history of tual Spirit of Plymouth there was a singular lack of
the Two Colonies.

permanence in the ministry of that town. Lyford, who was their first minister, proved to be a weak as well as a bad man, and he was finally deMinisters in posed and sent out of the Colony. The the Plymouth next minister was a youug man named Colony.

Rogers, who had been sent over from England. He proved to be "crazed in his brain," says Bradford, "so that they were fain to be at further charges to send him back next year." The third minister was Smith, who came over with Higginson in 1629 . He exercised his gifts among them five or six years. He was soon seen to be a man of mean abilities, and finally "laid down his place of ministry, partly by his own willingness, as thinking it too heavy a burden, and partly at the desire and by the persuasion of others." 1

Next came John Norton, who was "well liked and much desired of them," but who could not be persuaded to remain longer than one winter, and then departed to enter upon his grand career in Nassachusetts. Next came Mr. Raynor, an excellent man, but not of commanding abilities or character. Mr. Charles Chauncy was about three

1 Bradford. Young's Chronicles, 35 r. 
years associated with Mr. Raynor as Pastor, Mr. Raynor being Teacher. It was very fortunate for the Pilgrims that during these years of continued change in the pastoral office, they were able to fall back upon their excellent Ruling Elder, Mr. Brewster, of whom Governor Bradford has written that "when the church had no other minister, he taught every Sabbath, and that powerfully and profitably, to the great contentment of his hearers and their comfortable edification." 1 For thirteen years after the departure of Mr. Raynor the church in Plymouth was without a stated minister. Elder Cushman, the successor of Elder Brewster, preached, without being a pastor. In 1667 , John Cotton, Jr., came to them from Boston, and continued with the church for many years. ${ }^{2}$

The Royal Commissioners reported to the king, in I666, that they found in the Plymouth Colony "only twelve small towns," and that the people were so poor that "they were not able to maintain scholars to their ministers, but were necessitated to make use of a gifted brother in some places." 3 This statement of the Commissioners may have been true of some towns, but there were a number of university men settled as

1 Young's Chronicles, 467.

2 Goodwin's Pilgrim Republic.

${ }^{8}$ Hutchinson's Collection, $4 \mathrm{I} 7$. 
pastors in the Old Colony, - such as Ralph Partridge of Duxbury, John Lothrop of Barnstable, Henry Dunster of Scituate; Samuel Newman of Rehoboth, and Charles Chauncy of Plymouth. ${ }^{1}$

The contrast is very marked between such a ministry as these statements indicate, and the ministry which we find in the Colony of Massachusetts in its earlier years, when Higginson, Cotton, Norton, Hooker, Mather, Shepard, and The Ministers their associates were the intellectual of the Massa- leaders of their people, as well as their
chusetts colony. spiritual guides. Some of them had carried off the honors in the English universities. They were among the strongest men in the Colony. This difference indicates a great difference in the financial resources of the people of the two colonies, and possibly a difference in their intelligence also.

There were among the Puritans at that time a large number of men of broad and liberal learning. They were already beginning to send to the press books and pamphlets that were very creditable to their intelligence and their training. These books were published in London at first, and later in Salem and Boston. The literature of the first half century is creditable not only to the authors, but to the readers who were able to follow such close and logical thinking.

1 Goodwin's Pilgrim Republic, 510-5 50. 
Copies of these old books have been preserved as heirlooms in the older New England families, whence they are finding their way into the best historical libraries. Those who contributed to this literature were for the most part dwellers in the Puritan colony. The Pilgrims made some valuable contributions, but they are few in number. Boston and Cambridge were as truly the intellectual centres of New England in the seventeenth century as they are in the nineteenth. Harvard College was an important means of influence, and it had much to do in giving the pre-eminence to the younger Colony.

\section{$\mathrm{X}$.}

THE great enterprises undertaken for the general interest of New England had their origin in the Puritan colonies. The synod which prepared the Cambridge Plat- $\begin{gathered}\text { cambridge } \\ \text { plattorm. }\end{gathered}$ form, for example, was called by the

General Court of Massachusetts; and the men who had the leading part in framing that Platform, and so in moulding the Congregational polity for a hundred years, were either citizens of Massachusetts at that time, or men like Hooker, who had once belonged to that Colony. Governor Bradford was present as the messenger of the church in Plymouth. So was Ralph Partridge 
of Duxbury, and possibly two or three others from the Old Colony. John Cotton of Boston, Richard Mather of Dorchester, and Ralph Partridge of Duxbury were appointed to draw up, each by himself, a model of church government. The one drawn up by Richard Mather was for substance adopted by the synod. Mr. Partridge also prepared a model, which was not acceptable to the majority, on account of its Low Church tendencies. The manuscript copy, which is still preserved in the Library of the Antiquarian Society at Worcester, shows that the Pilgrim pastor was not as advanced a Congregationalist as the Puritans had already become. ${ }^{1}$ This was all that the Plymouth Colony contributed toward the result of this most important synod.

The confederacy of the four principal colonies of New England had its origin in the Puritan

The Niew

England Confederacy.

Colony of Connecticut. Plymouth was a member of it, with the colonies of Massachusetts Bay and New Haven; but Plymouth never had a leading part in the Confederacy. This was the first in the long series of unions between the English colonies and provinces of North America, which led, in the course of time, to the confederation of the States

1 Dr. Dexter's Congregationalism as seen in its Literature, $335-33 \mathrm{~S}$. It should be added that the present Congregationalism is much nearer that of the Plymouth Church than that of the Cambridge Platform. 
in the national Union. On the whole view of the history, it is plain that the political influence of Plymouth was never very great.

\section{XI.}

In respect to legislation, there was less difference between the Pilgrim and the Puritan colonies than is commonly supposed. Both regislation. were influenced by the precedents to which they had been accustomed in England, and by the general spirit of the seventeenth century. The Pilgrims had profited by the larger and more tolerant spirit of the Dutch Republic. In both colonies the people claimed the rights and liberties of Englishmen. In both, after a few years, the people were taxed for the support of the regular ministers, just as they had been in England. Punishments which would now be considered harsh and cruel, such as the use of the stocks, the pillory, and the whipping-post, were used in both colonies.

The laws of Plymouth against the Quakers were as severe as those of Massachusetts. Meetings of the Quakers for public worship Lawsagainst were forbidden by the laws of the Col- the Quakers. ony of Plymouth, and all who attended such meetings were liable to a fine of ten shillings, and all who spoke at such meetings were liable to a 
fine of forty shillings. Men in the Plymouth Colony were disfranchised because they were Quakers, and also because they had harbored Quakers in their houses. The law provided that the people called Quakers could be arrested, sent to the House of Correction, put in the stocks, or in the cage, their books could be seized, and their horses also; they could be banished, and, by a late law, they could be put to death. ${ }^{1}$ The last law, however, was never executed.

- The laws of Plymouth provided that a witch should be put to death. The Pilgrims shared the common belief of their time that human beings actually had direct dealings with the Devil, and Laws against that they used the power which he gave witchcraft. them to torture and to destroy their enemies; and they thought it their duty to punish in the severest way those who were guilty of such an offence against their kind. They embodied this common belief in their laws.

But there was a difference between the two colonies in respect to the execution of the laws. The Quakers were fined, and imprisoned, and disfranchised, and even whipped in the Plymouth Colony, not, however, on account of their religious opinions, but because of their disorderly practices.

1 The authority for these statements is found in the printed Records of the Plymouth Colony, vol. xi. 11, 12, 95, 100, 172. Goodwin's Pilgrim Republic, 478-490, 531. 
But the merciful spirit of the people would not have tolerated the execution of the death-penalty for such offences. They adopted the wiser course of shutting them up in prison when they became persistent in disturbing the good order and peace of the community, as The Merciful Spirit of the Pilgrims. the Quakers of that day frequently did. It is quite possible that this leniency of the people of Plymouth may have influenced the people of Massachusetts to repeal their law which prescribed the penalty of death for such offences.

There were two trials for witchcraft within the Colony of Plymouth. But the people had cooler heads than the people of Salem and of Trials for Boston. They cross-examined the wit- witchcraft in nesses, and scanned their testimony, and colony. found the charges not proven. The people of Massachusetts came at length to the same judgment. But before they reached it, they had done many acts of cruel injustice, which are the darkest stain upon their history.

These classes of laws, however, constitute but a small part of the legislation of the Colony of Massachusetts Bay. There is much in the segisiation records of the Colony which shows how ${ }_{\text {Massachusetts }}$ vigilant and how wise the people of that colony. Colony were in protecting the rights of the citizen, in caring for the unfortunate, in restraining crime, in securing the financial prosperity of the 
community, and in protecting it from the dangers which threatened it. That body of laws has exerted an influence far beyond the limits of Massachusetts, and has had much to do in mould. ing the institutions of our nation.

\section{XII.}

IN summing up the results of this comparison of these two colonies, we shall do well not to judge either the Pilgrims or the Puritans by the standards of our times, because our times owe very much to their teaching and example. For we know that -

"Men may rise on stepping stones

Of their dead selves to higher things."

Nor should we give too much weight to the superiority of the Puritans in numbers and Results of wealth, and in intellectual and social comparison. culture. For the influences that rule the world do not come from such things as these. "The meek shall inherit the earth." It may be fairly claimed that the influence of the Puritans upon New England has been greater in some respects than that of the Pilgrims. The energy, the enterprise, the political sagacity, the genius for creating new types of government, - these are the inheritance of New England from the Puritan fathers. The intellectual life of New England, 
and much of its best religious life, have come from them. I do not know that the Pilgrims were more devout than the Puritans. There is no evidence at all, that I have been able to find, that the religious life in the churches within the Colony of Plymouth was higher than that within the churches of the Colony of Massachusetts. Governor Bradford lamented, in his last days, the degeneracy of his people at Plymouth, just as the ministers in Boston lamented the decline from the old spirit of New England.

But the Pilgrims had been purified by the fires of a fiercer persecution. They had learned lessons of patience and of gentleness in the hard school of adversity. Their "gentleness had made them great." New England would not have had the same elements of power if its founders had all been like those who came in the Mayflower. The New England character would not have given its impress to a great nation like this republic. But, after all, the beauty, the poetry, of New England have come, in great part, from those who landed on Plymouth Rock. They have taught the world a larger tolerance, gentler manners, purer laws. We have learned from them the grand possibilities which wait for men of faith, who are content to bow their heads to the storm, and commit their way unto the Lord, and trust Him to bring them to the desired haven. 



\section{III.}

\section{The Early Ministers of New England.}




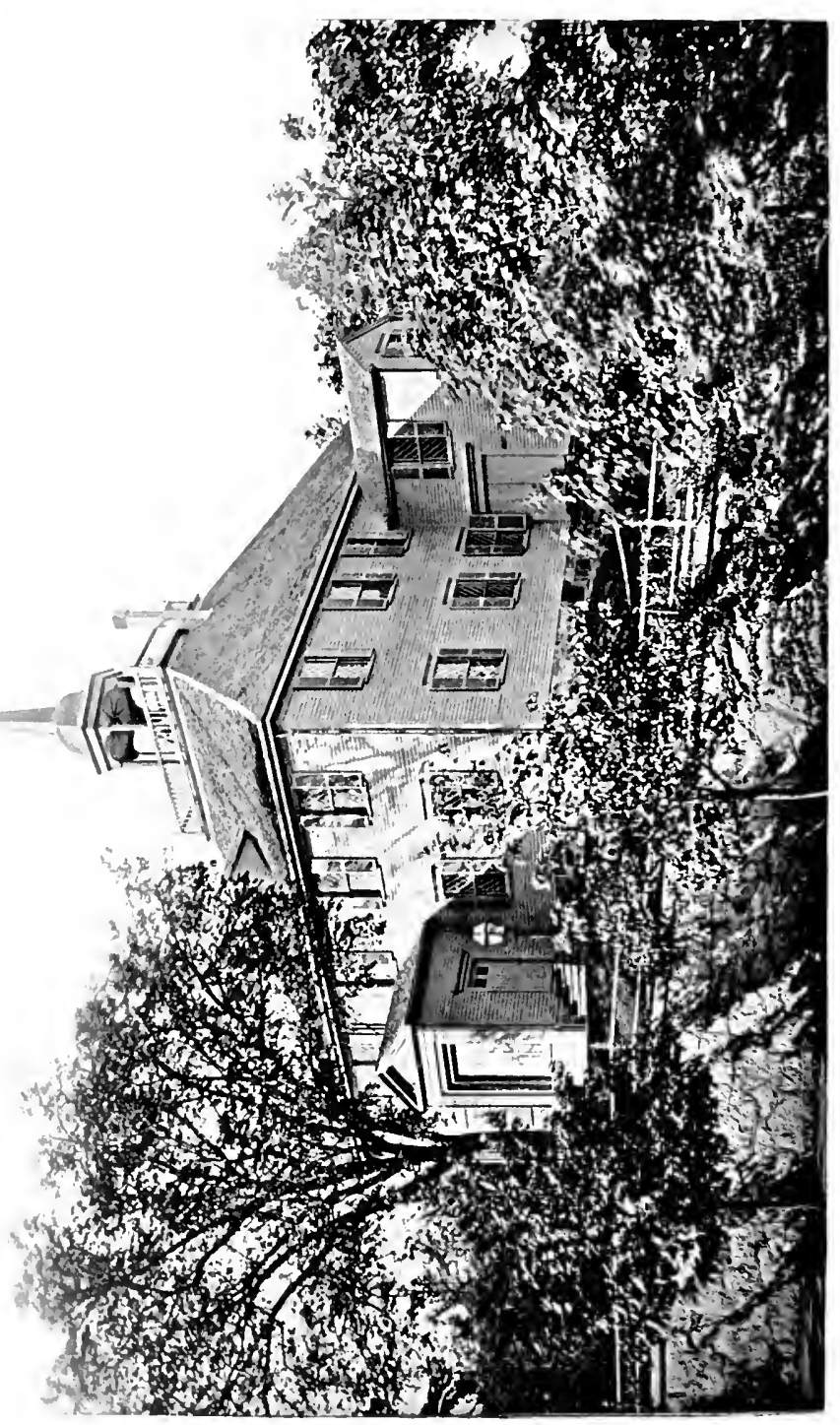




\section{The Early Ministers of New England.}

THE Puritan ministers were the best repre1 sentatives of the Puritan fathers. The materials for the study of their character and work are provided for us in their own writings, and in the writings of those who were associated with them in planting the New England colonies. There was a reason why those men published so many books and pamphlets in the years when they were so much engaged in laying the foundations of the Colony. They were, as we have seen, the pioneers of the Puritan party in England, and it was part of their work to send home clear and definite accounts of the towns and of the churches which they were planting. These narratives disclose to us the motives and the principles which governed them. They are the original documents from which the early history of New England can be written. 


\section{I.}

THESE early ministers were of course in sympathy with the intense Protestantism of the The Early English Puritans. They had been Ministers had
been Moulded by Persecution. Many of them had been driven from their parishes, after years of faithful service, by the new requirements of the dominant party in the Church. They had suffered from heavy fines, and from imprisonment. Some of them had been driven from England years before they came to America. They had found a place of refuge in Geneva, and had come under the Calvinistic influences of that city. These men had cut loose from human traditions, and had formed the habit of appealing to the Scriptures for the rules of life, and methods of worship, and of political administration.

They were men of one book, and that book the Bible; and they regarded the Book as the sufficient rule in all matters, secular as well as ecclesiastical. They had also a remarkable sense of the authority of righteousness. It has - been said by French writers that the English people differ from the French in that they are inclined to exalt conscience as the supreme guide of life. But among the English people the Pilgrim 
and Puritan ministers were pre-eminent in this regard. They tested all things by a moral rule.

They had also a profound sense of the presence of God in the world, and of the responsibility of every man to Him for every act of his life. With this, there was also a conviction of the dignity of man, as a free being, responsible directly to his Creator. These high views raised them above the lower motives of life. Their religion gave them, as one has recently said, "a superb and shining courage." It mattered very little to them what consequences might come from their actions, so long as they had the approval of their consciences. Their history is full of incidents which show that they did their work from day to day as though standing on the threshold of the spiritual world. In that light, duty becomes the supreme law. It is related of Governor Cranfield of New Hampshire, that he sent an order to Rev. Joshua Moody, the minister of Portsmouth, to administer the Lord's Supper, according to the rites of the Church of England, to himself and two of his friends, on a certain Sunday. But neither the Governor nor his friends, according to the opinions of $\mathrm{Mr}$. Moody, were prepared to receive the Sacrament. Sc the minister refused to obey the order of the Governor, and, in consequence, was sent to prison for six months. It is related of another Puritan, 
- not a minister, - that on the famous Dark Day, when the Day of Judgment was suppose:d to be at hand, he refused to consent to an adjournment of the Legislature, of which he was a member, saying, "Either the Day of Judgment has come, or it has not; if the Day has come, I choose to be found at the post of duty; and if it has not come, there is no reason for an adjournment."

It is difficult to conceive of a finer opportunity than the New England Puritans had to work out a fresh and original system of religion and of government. Given those vigorous AngloSaxons, - trained in the hard school of adversity, men of faith and prayer, who had searched all history for examples, - transplanted to the wilderness, and left by themselves for a century and a half, to build, as best they could a Church and a state, and the world might be sure that something would be evolved that would be worthy the attention of the most thoughtful students of history.

\section{II.}

The early ministers of New England were, as a class, men of thorough education and culture. John Robinson, ${ }^{1}$ who certainly deserves to be

1 Prince's History of New England, 38. 
counted among the ministers who formed the character of the Pilgrims, although he never came to America, was a graduate of Cambridge, in I600, and was a man of great learning, as well of rare sweetness of temper, and of a broad and tolerant habit of mind. While his people were settled at Leyden, he was connected with the university of that city, and was put forward as the ablest champion of Calvinism against the Arminians. John Wilson and John Cotton, the two earliest pastors of the First Church in Boston, were both graduates of Cambridge, and had both been for years clergymen in the Churcn of England. Cotton had been a Fellow and a Tutor in Emanuel College. For more than twenty years he was vicar in the Church of St. Buttolph, in old Boston, "perhaps the most stately parish church in England," says Mr. Palfrey, - "a cathedral in size and beauty." His name is still held in honor in St. Buttolph, and a beautiful chapel has been recently fitted up, in that church, which bears his name, and a Latin inscription to his memory. From this superb temple he came, while in the vigor of his manhood, "to preach the Gospel within the mud walls, and under the thatched roof of the first meeting-house in Boston." 1 Cotton Mather says of him, that "he was a

1 Palfrey, History of New England, vol. i. 368. 
walking library, a universal scholar, an indefatigable student, the Cato of his age for his gravity, but having a glory with it which Cato had not." 1 Francis Higginson and Samuel SkelThe Learning of the First Ministers of New England. ton, the first ministers of Salem, were also graduates of Cambridge, and had been clergymen in the Church of England. Roger Williams was graduated from Pembroke College, Cambridge, and was probably admitted to orders in the National Church. He was a man of learning, a close observer of nature, and was the master of a clear and vigorous English style.

Four years after the settlement of Boston, there were thirteen ministers in Massachusetts, most of them graduates of Cambridge or Oxford, and several of them distinguished for professional attainments, and most of them men who had held livings in the Church of England. Ten years later, there were about eighty ministers in New England, - that is, one in three hundred of the population. A number of these ministers were men of good property, and aristocratic connections. Generally they were graduates of the English universities. The education which those universities imparted at that time was such as the classic writers and the great statesmen of the seventeenth century received. 'Those ministers, as a rule, were

1 Quoted in Sprague's Annals of the American Pulpit, vol. i. 29. 
able to read both the Old and New Testaments in the original tongues, and were familiar with the best theological literature of their time. The people demanded an educated ministry. The Royal Commissioners reported to the king, in 1666 , that "every town or village in Connecticut had a scholar to their minister."

Thomas Hooker, who was the leader of the Connecticut Colony, was distinguished as a scholar at the University of Cambridge, where thomas he was graduated, became a clergyman Hooker. in the English Church, was silenced in the time of Laud, went to Holland, and, in I633, came to New England. Cotton Mather speaks of him as "the incomparable Hooker,- a man in whom learning and wisdom were tempered with zeal and holiness." The Mathers - Richard, Samuel, Increase, and Cotton - were among the most learned and accomplished men of their time. The first was educated at Oxford, and the three others were graduated from Harvard. They showed that the education that was given by the new college, was a fair equivalent for that which the old English universities were able to impart. John Norton, also a graduate of Cambridge, came to Boston in 1635 , and was settled at Ipswich, and was afterwards the pastor of the First Church in Boston. He was a man of great ability, a fine classical scholar, and a well read divine, author of a System of Divinity, 
and of a number of other theological works which had great influence in their day. Among them was the first book in the Latin language produced in Massachusetts.

Governor Winthrop states that as early as $16_{3} 8$ there were probably forty or fifty sons of Cambridge dwelling in the villages of Massachusetts and Connecticut, and not a few of the sons of Oxford; while Mr. Palfrey states that there were in New England, at any time between I630 and I69o, as many sons of these two famous nurseries of learning as would have been found in a proportionate number of their fellow-subjects in the Mother Country. ${ }^{1}$

We have some account of the libraries of the early settlers of New England, laymen as well as ministers. Elder Brewster left a library of two hundred and seventy-five substantial volumes. Hooker's library was appraised after his death at three hundred pounds, Davenport's at two hundred and thirty-three pounds, Stone's at one hundred twenty-seven. John Harvard, the founder of Harvard College, left a library of three hundred and twenty volumes, classical and patristic works, as well as modern writings in theology and general literature. ${ }^{2}$ When we consider that the sums at which these libraries were appraised represent the salary of a minister in those times for three or

1 Palfrey, vol. ii. 38-39.

2 Palfrey, i. 549; vol. ii. 45. 
four years, we can see that they prized good books, and paid more for them than for almost anything else. Even more decisive in regard to the intellectual spirit of the early ministers of New England is the quality of the books which they Intellectual published. One who reads them is spirit of the constantly surprised at the extent and Ministers. thoroughness of the learning of their authors. The founding of Harvard College, in 1636 , was perhaps the most decisive evidence of their love of learning. The founders said it was their purpose "to advance learning, and perpetuate it to their posterity, dreading to leave an illiterate ministry to the churches, after our present ministers shall lie in the dust." 1 And so the people of the Colony taxed themselves heavily, from year to year, for the support of the college. They knew that the free church in a free state, which they were trying to establish, must rest upon the intelligence of the people, and that the people are dependent in large part upon the culture of their professional men.

\section{III.}

THE early ministers of New England were also men of great dignity of character, and courtliness of manner. The age of Queen Elizabeth, and of the Stuarts, was a time when the dress and man-

1 New England First Fruits. 
ners of professional men, and of public officials, were of the first importance. There was a great

The Manners of the Early Ministers. deal of formality in the intercourse of such persons with other men. The Puritans brought with them the style and manners of the higher classes in England, and they were very careful to guard against the tendency, which must always be felt in a new country, toward ruder manners and a lower culture. The Governor and the judges wore their official robes on important public occasions. The portraits which we have of some of the early ministers of Boston, and of some other places in Massachusetts, represent them as wearing the gown and bands. ${ }^{1}$ The practice may not have been followed in the small towns; and yet, if I may judge from the portraits I have seen, it was not uncommon. The Puritan ministers had been, the most of them, ministers

1 One cannot be sure of the authenticity of old portraits, in all cases. The portrait of John Cotton, $e . g$. which is given without the suggestion of a doubt, in the Memorial History of Boston, and in the History of the First Church, is now known to belong to some descendant of the great Puritan divine. It is possible that some other portraits are not authentic. The following are represented in old portraits with gown and bands: John Wilson, Richard Mather, Increase Mather, Cotton Mather, Samuel Willard, Benjamin Coleman, John Davenport, Charles Chauncy, Thomas Prince, John Hancock of Lexington, William Cooper, Benjamin Wadsworth, Samuel Phillips of Andover, and Stephen Williams of Longmeadow. After the time of Charles II. the ministers are represented with the wig. This list can be easily extended, but these names, from different localities, indicate the general custom. 
in the Church of England, and had been accustomed to wear the priestly robes. So far as the customs of the National Church seemed to them to tend toward Popery, they laid them aside; and the Puritans certainly had decided objections to certain forms of clerical vestments, which the reactionary party - " the high fliers," as they were called - in the English Church, were disposed to adopt. But there is no reason to suppose that the simple clerical vestments which were used by the Protestant ministers in the English Church were objected to by the Puritans. But the gown and bands which the ministers of New England used, came from Genevan and Scottish sources, not from prelatical; and they put them on, as the Presbyterian and Dissenting ministers of Great Britain do at the present time, simply as the customary badges of their office.

The early Puritan ministers who came from England represented the best life of the Mother Country. Three of those ministers - Cotton, Hooker, and Davenport - were invited to sit in the Westminster Assembly. One of them, Increase Mather, was sent to represent the Colony in England, when there was need of skilful diplomacy; and he was kept abroad, as the agent of the Colony, a number of years. He was a man of practical wisdom, gentle without weakness, and cautious without timidity. His face, as represented in the 
old portraits, was almost feminine in its aspect, as far as possible from the hardness that is so often ascribed to the Puritan ministers.

There was a dignity and authority in the pastorate in those times which could not outlast the simple habits of Colonial days. The minister was at the head of a little theocracy. He used his power wisely and unselfishly, for the most part; but he was a man of power by virtue of his office as a minister of religion. "Are you, sir, the person who serves here?" said a traveller, to the pastor at Rowley, whom he met in the street. "I am, sir, the person who rules here," was the prompt reply. Professor Park has described Rev. Samuel Phillips, who was pastor of the church in Andover eighty years after the settlement of New England, riding on horseback through his parish, with his wife on a pillion behind him, his majestic figure crowned by a three-cornered hat, as one whom every traveller would be sure to recognize as a man who held control over his diocese. $\mathrm{He}$ governed well. He was loved as well as feared. He was a man of learning, author of nineteen books and pamphlets, an energetic pastor, a pungent and impressive preacher, to the hearts, but especially to the consciences of his people. ${ }^{1}$

Mrs. Harrict Beecher Stowe has given some interesting sketches of some of the old-time min-

1 Bibliotheca Sacra, 1856-1861. 
isters, which are drawn, for the most part, from reliable sources, though none of them relate to the first period of Puritan history. "The most vivid image of respectability and Lothrop. majesty," she says, "which a little boy, born in a Massachusetts village, could form, was the minister. In the little theocracy which the Puritans established in the wilderness, the ministry was the only order of nobility. It was their voice that determined, cx-cathedra, all questions, from the choice of a Governor to that of the village schoolteacher." She describes Parson Lothrop, a successor of the missionary Eliot, as a fair representative " of the third generation of the ministers of Massachusetts; one of the cleanest, most gentlemanly, most well-bred of men, never appearing without all the decorums of silk-stockings, shining knee and shoe buckles, well-brushed shoes, and the ample, immaculately-powdered clerical wig, out of which shone his calm, clear, serious face, like the moon out of a fleecy cloud. His Sunday sermons were well-written specimens of the purest and most Addisonian English. He had the formal and ceremonious politeness of a gentleman of the old school. He was ever gracious and affable, as a man who habitually surveys every one from above, and is disposed to listen with indulgent courtesy, and who has advice for all seekers; but there was not the slightest shadow of anything 
which encouraged the most presuming to offer advice in return. Parson Lothrop was so calmly awful in his sense of his own position and authority, that it would have been a sight worth seeing to witness the coming of any of his parish to him with suggestions and admonitions." 1

The sketch which Mrs. Stowe has drawn of Dr. Hopkins of Newport will answer for the ministers of the next generation. "He entered the dining-room with all the dignity of a fullbottomed, powdered wig, full flowing coat, with ample cuffs, silver knee and shoe buckles, as

Dr. Samuel Hopkins. became the majesty of a minister of those days. The company rose at his entrance. The men bowed, and the women courtesied; and all remained standing while he addressed to each, with punctilious decorum, those inquiries in regard to health and welfare which preface a social interview." 2

\section{IV.}

IN respect to the maintenance of the ministers, it was ordered by the Court of Assistants of the

The Support of the Ministers.
Colony of Massachusetts, at their first meeting on this side the Atlantic, that houses should be built for the ministers "with convenient speed," and that an allowance of thirty pounds a year be made to each of the

1 Old Time Folks, 3-10. 
ministers from the common treasury. In Boston, the ministers were provided for by voluntary contributions made every Sunday in the churches. This custom was followed in that town for more than a century. In some other towns the same method was followed for a few years. The first meeting-house in Boston, and the house for Mr. Wilson, the first minister, were paid for out of a voluntary contribution. The cost of the two was about a hundred and twenty pounds. After a few years, the larger number of the churches adopted the method of raising the salary for the minister by taxation. In $16_{54}$, a law was passed which provided for raising money by taxation for the salaries of ministers, the erection of meeting-houses, and for building or hiring houses for the ministers to live in. ${ }^{1}$ Cotton Mather said that the ministers of the Gospel would have a poor time of it, if they must rely upon a free contribution of the people for their maintenance; and so it was "enacted that the salary for the minister who has been duly elected by the majority of the people shall be levied by a rate upon all the inhabitants; and the minister, thus chosen by the people, is the king's minister, and the salary raised for him is raised in the king's name, and is the king's allowance unto him." 2

1 Palfrey, vol. i. 317 ; vol. ii. 39. Winthrop, vol. i. 87 . Mass. Records, i. 87.

${ }^{2}$ Ratio Disciplinæ, 20-2I. 
He says further that the churches of New England consider not so much the age as the worth of a candidate for ordination, so that they even accept very young ministers of great promise, and their youth is no prejudice against them.

It was common to provide what was called a settlement, in addition to the annual salary, in order, as they said, "that if the minister should die during his ministry among them, his family may have a comfortable maintenance." The church in New London, Connecticut, for example, agreed to pay their minister eighty pounds a year, for three years, and afterwards " as much more as God shall move our hearts to give, and we do find it needful to pay." He was to have "all such silver as is weekly contributed by strangers, to help toward buying of books." The people were also to pay the expense of transporting his family and effects from Concord, and also to provide him a house, and small farm, and firewood free of charge. ${ }^{1}$

In Good News from New England there are definite statements in respect to the salaries of ministers at that time: John Norton of Ipswich had $£ 70$ a year; Richard Mather of Dorchester, $£ 70 ;$ John Cotton of Boston, £90; while John Wilson of the same church had $£ 60$; Thomas Parker of Newbury, $\mathcal{L}_{40}$; and IVilliam Thompson of Braintree, $£ 30$. The salary of the President of

1 Felt's Ecclesiastical History of N. E., vol. ii. 33 I. 
Harvard College in those days was $£ \mathrm{roo}$, afterward increased to $£_{150 .}{ }^{1}$ In the earlier years of the Colony, much of the salary was paid in provisions. There was often an agreement that a certain proportion should be paid in this way.

In most instances where we are able to get definite accounts of ministers who lived in the second or third generation of the Colony, we find that they owned the dwellings which they occupied, and that they also owned a farm from which a part of their maintenance was derived. Peter Thatcher of Milton had a farm, and was so well informed in respect to agriculture that he was constantly consulted by his parishioners in respect to the management of their farms. Even President Edwards of Northampton was a farmer; and though he did not know his own cows when he saw them, Mrs. Edwards managed the business so well that a large part of the support of the family came from it. Rev. Jonathan Strong of Randolph had a farm, which he cultivated. He used to labor with his hands a large part of the week during the summer, and to teach Latin and Greek to boys preparing for college in the winter. These examples, taken from different periods of New England history, are typical illustrations of the close connection of the ministers with agriculture. New England, for the first two centuries

1 This was published in London in I64S. 2 Sprague's Annals. 
was almost exclusively an agricultural country, and the pastors were the better fitted for their work by a certain familiarity with that way of life. Undoubtedly this practice contributed to the permanence of the pastorate, and to the independence of the ministers. They were, for the most part, men of substance. They had a position and influence as permanent citizens, who were rooted in the soil. Having their permanent homes, the ministers were not inclined to move from place to place. They had their own horses and carriages, and made long journeys in their own conveyances. A minister, in the old times, was not usually a poor man. He was the equal of his parishioners in the things that give one an independent position in the community. His office was respected; his income was sure; his home was his own; and he could go and come with as much freedom as any other busy man.

Out of this state of things grew the old-time ministerial hospitality. It was not common for ministers on their journeys to stop at hotels. Each country pastor was eager to welcome a brother minister on his journey; and so it came to pass that the pastors had the opportunity very often to exchange thoughts and impulses with each other. These habits of the New England ministers continued to a time within the memory of some now living. The old independence of 
the ministers, living on their own homesteads, among their people, and cultivating the generous hospitality which was common before the days of railways, went along with habits of thorough investigation, and independent thinking, along with a permanent pastorate, the catechetical instruction of children, and a profound pastoral influence.

\section{V.}

In respect to the dwellings of the early ministers of New England, and their furniture, their way of living, and their food, the information is abundant. In Massachusetts, as in the other colonies, the log-house, very often with Dwellings of a thatched roof, served a large propor- the Ministers. tion of the people for a divelling in the early years. The houses of the ministers were like those of the people. For a few years after the settlement of Boston, the larger part of the houses in that town were built of logs. The old writers state that the tall grass, gathered on the beaches, was much used for thatching the roofs of houses. But the improvement was rapid. A Puritan writer of 1642 says, "The Lord hath been pleased to turn all the wigwams, huts, and hovels the English dwelt in at their first coming, into orderly, fair, well-built houses, well furnished, many of them, together with orchards filled with goodly 
fruit-trees, and gardens with variety of flowers." 1 There is an old house, built in 1639 by Rev. Mr. Whitfield, which was still standing a few years ago, in Guilford, Connecticut, which was supposed to be the oldest house in the United States, north of Florida. The walls are of stone, very thick, from a ledge not far away. The roof is inclined at an angle of sixty degrees. The height of the first story is seven feet, eight inches, and that of the second six feet, nine inches. In every principal room there is an ample fire-place, opening into the great old-fashioned chimney. This house, however, was exceptional. The small log-cabin, with the old well-sweep outside, and with cultivated fields about it, - this was the home of the ministers of the first generation. They were enterprising men however, and, as the country became older and richer, the ministers secured more comfortable dwellings.

The articles of furniture which are carefully preserved in our time, and which are said to have come over in the Mayflower, give one the impres-

Furniture of the Puritan Homes. sion that the Pilgrim homes were well furnished. Many of the articles are of English oak, elaborately carved. One may see cuts of them in volumes that have been recently published. But the larger number of these articles are not as old as the Mayflower.

${ }^{1}$ Johnson's Wonder Working Providence, I74. 
If they had all been loaded into that small vessel, " there would have been no room," as one has said, "for the Pilgrim Fathers." 1 It is true, however, that some of the old furniture which is still preserved did come from England, at various times, during the Puritan exodus, and it is also certain that some of their homes were well furnished. But the furniture in most of the early dwellings was very plain, and of moderate cost. Most articles of table furniture were made of pewter. No forks appear in the early inventories of household goods. Governor Bradford had "four large silver spoons, and nine of smaller size." But he was accounted one of the rich men of the Colony. In I 662, one of the principal men of Salem left to his daughter by will, "two pewter platters and likewise an iron pot." From such items as these, which appear in a great many inventories, it would seem that the style of furnishing was a long way below that of country homes in our time. On the other hand, a few chairs and tables and other articles which undoubtedly belonged to the early Colonists show that some of them brought into the wilderness the best from their ancestral homes.

The food used in the homes of the early ministers was not too rich for health and comfort. Not much butcher's meat was to be had at first. The few domestic animals were permitied to multiply

1 Palfrey, vol. ii. 64, note. 
that the fields might be stocked with flocks and herds. But game and fish were abundant. You Their Food. recollect that the Pilgrims sent out a hunting party before their first Thanksgiving, that they might have "rare and dainty fare" for the festival. In 1642 , however, "beef, pork, and mutton were common in many houses," according to an old writer, and also "apples, pears, and quince tarts, instead of their former pumpkinpies; poultry they have plenty, and great variety, and they have not forgotten the English fashion of stirring up their appetites with variety of cooking their food." 1

"In the early days of New England," says Mr. Palfrey, "wheaten bread was not so uncommon as it afterwards became, but its place was largely supplied by preparations of Indian corn. A mixture of two parts of Indian meal, with one part of rye flour, seems for two hundred years to have furnished the bread for the great body of the people." The morning and evening meals, for a hundred and fifty years, were commonly of boiled Indian meal, - hasty pudding, - with milk or molasses, or else there was a porridge made of beans or peas flavored with salted beef or pork. That was the age of homespun, - plain living and high thinking.

Tea was not much used in the first century and

1 Wonder Working Providence. 
a quarter of New England history, nor coffee for a century and a half. Beer, such as could be brewed in families, was in common use; and after the orchards were grown, cider was a very Drinks. common drink. Wine and spirituous liquors were brought into the country in considerable quantities, and were used freely by the people, ministers as well as laymen. It was common for the people to provide these liquors for their ministers whenever they came to their homes, and also for the ministers to offer them to their guests. Yet a careful observer, writing from Massachusetts in I64I, said, "Drunkenness and profane swearing are but rare in this country." Another writer said, "One may live there from year to year and not see a drunkard, hear an oath, or meet a beggar." "In seven years," said another, " among thousands there dwelling, I never saw any drunk, nor heard an oath, nor saw any begging, nor the Sabbath broken." 1

\section{VI.}

THE New England Puritans called their places of worship meeting-houses, not because they were places of assembly for the people, but because they went there to meet the Lord, and to receive His blessing; as the children of Israel used to go to the Tabernacle in the Wilderness, to receive com-

1 Lechford, 69. New England First Fruits. Hugh Peters. 
munications from God. Cotton Mather said, "I find no just ground in Scripture to apply such a trope as church to a house for public worship. A meeting-house is the term that is most commonly Meeting- used by New England Christians; and Houses. every town, for the most part, can say, we have a modest and a handsome house for the worship of God, not set off with gaudy, pompous, theatrical fineries, but suited unto the simplicity of Christian worship." 1 The meeting-house was the central building of a Puritan town. The village grew up around it, and the country roads were laid out with reference to it. The first meetinghouses were built of logs, and thatched. The pulpit was a simple desk. There were rough benches on either side of the central aisle. The men sat on one side, and the women on the other. Sometimes the meeting-house was surrounded by palisades, with a sentinel at the gate; and the people used it as a place of deposit for powder, and also for their most valuable possessions.

Later, the meeting-houses were built on a larger plan, and covered with boards or planks, and the roofs were shingled. The form of the village meeting-house, in the second period of our history, was nearly square, with a roof in the form of a pyramid, crowned with a steeple. If the people could afford the luxury of a bell, it was hung in the steeple, and the bell-rope hung clown in the centre

1 Ratio Disciplinæ. 
of the audience-room. The sexton used to stand half-way between the principal entrance and the pulpit, when he rung the bell. The only one of these Puritan meeting-houses now in use is the one in Hingham, Massachusetts, which was built in 1681. It is of wood, and is sixty-five feet by forty-five. The pulpit stood in the middle of the long side. The galleries were on three sides. The old timbers still show the marks of the axe, and are massive enough for the ribs of a ship. This ancient meeting-house, which is commonly called the Old Ship, is now a well-furnished and elegant Unitarian church. The churches of that time in New Haven, and in Milford, Connecticut, in Andover and West Springfield, Massachusetts, were fine specimens of this type. Of similar form was the thirl edifice of the First Church in Boston, built in I 7 I 3 , and occupied by that congregation for almost a century. ${ }^{2}$

That style of church architecture, which was followed in New England for about a hundred years, was peculiar to the Puritans. The churches in the old country with which they were familiar, were much like the churches of our own time in form. But our fathers did not desire to reproduce those old models in their new homes. The

1 For a view of this ancient Meeting.House, as it is at the present time, see the plate which faces page i 7.

2 Dr. Dexter's article on Meeting-Houses, Congregational Quarterly, vol. i. I86. President Porter's article, New Englander, i $\$ \$_{3}$, 303. 
churches of England had been built while that country was under the Romish ritual. They had been used for the Mass, and could easily be adapted to the services of the old Church. The Puritans made it a point to avoid whatever could be suggestive of the forms of worship which they disliked. So they provided buildings spacious enough to accommodate the people, and plain enough to guard against ecclesiastical pomp and the traditional forms of worship. Hence that style of building, which was once common in all parts of New England, that used to be called the "barn meeting-house." Its original form, before porches and the steeple were added, was a perfectly plain structure, almost square, without a chimney or anything to mark it as a place of worship. It had doors on three sides, with two, sometimes three, rows of windows. The principal door was placed in the middle of one of the long sides, the pulpit being in the middle of the opposite side. The side-doors were placed in the middle of each of the ends. Galleries were built on three sides. The pulpit was high, and was overhung by the sounding-board, suspended from the bare and unpainted rafters by a slender iron rod. This sounding-board looked not unlike a huge extinguisher, made ready to drop upon the head of any preacher who should prove unfaithful to his trust. ${ }^{1}$

1 The sounding-board was borrowed from the churches of Europe, where it is still common. 
The people were seated, in the early days, on rough benches, the men and women on opposite sides. Pews were not provided at first. Now and then a special vote was passed by the town authorizing some person to build a pew in the meeting-house at his orvn expense. Squares on the floor, about six feet by six, were deeded to individuals, on which they erected pews to suit themselves. Later, it was customary to require the pews to be built "with wainscot worke, and all of a kind." These pews were apt to be set up next the wall, or in front of the pulpit. Sometimes they had curtains, which screened the occupants from view. The pews gradually encroached upon the open spaces, until the practice was adopted of providing pews for all the congregation. With permanent pews came the practice of seating families together. The pews were large and high, with seats on four sides, because the average Puritan family was numerous.

A committee was appointed to assign seats in the meeting-house. This was called dignifying the seats, because they were assigned according to the social position, or the wealth of the occupants. The best seat was someThe Pews. times assigned to the man who paid the highest tax in the parish. Sometimes the committee were instructed "to have respect unto them that are fifty years old and upwards, others to be 
seated according their pay." In one instance, we have a record that the committee was instructed "to have respect to age, office, and estate, so far as it tendeth to make a man respectable, and to everything else that hath the same tendency."

A third modification in the form of the meeting-house was adopted in what may be called the The Meetingthird period of New England history. House of the As the danger from Popery did not Third Period. seem to our fathers to be so great as it had appeared to be in the beginning, they were disposed to build their houses of worship much ncarer the traditional type of a Christian church, a form borrowed perhaps from the Roman basilica. The ground plan was no longer square, but oblong. The steeple was placed at the front end, and usually projected a little from the main building. The pulpit was commonly, though not always, at the end opposite the main entrance. The ample galleries were still on three sides of the audienceroom, and were provided with pews. There were double rows of windows, on three sides. At the end where the pulpit was placed, there was one window, larger than the others, and arched at the top. The pulpit was still far above the pews, with the sounding-board above it.

One of the oldest examples of this style, now in constant use, is Christ Church in Salem Street, Boston, built in I723. This church has two gal- 
leries, the upper of which is still called "the slaves' gallery." A much finer specimen is the Old South Meeting-House, on Washington Street, Boston, erected in 1729. The First Church in Springfield, the First in Westfield, and the Old South in Windsor, Vermont, are fine examples of this style. This became the common form for a Congregational place of worship, in the later years of the last century and the first half of the present century. Some of these old buildings have been changed in recent years, but they are easily recognized, by an experienced observer, as belonging to the type of the later Puritan age. It is characteristic of these buildings, that they are all admirably adapted to their purpose as places for preaching the Gospel. They can accommodate a larger number of people than buildings of other forms. The pulpit is still the central object, and the occupants of every pew are in view of the preacher.

The old meeting-houses of New England embodied the ideas of the Puritan ministers. There were few professional architects in the new country, and in many instances the meeting-house was planned by the minister. The plainness and simplicity of those places of worship suited the worshippers. Our fathers would have felt uncomfortable in a beautiful Gothic church, such as those in which they had worshipped while in England. The plain meeting-house was in harmony with the 
way of worship which they had chosen. If the pulpits were high, it was because the ministers were expected to stand far above the people, and to be shining examples of Protestant principles. They would have been afraid of low pulpits, lest they might tend toward Popery and the service of the Mass.

The meeting-house was never lighted except by the sun, until singing-schools, at a comparatively

Lighting and late period, made it necessary to introWarming of the duce candles. Night meetings in the
Meeting-House. Meeting-House. meeting-house were considered quite improper; and the Puritan ministers would have thought candles too suggestive of the superstitions of the Church of Rome. There were no fireplaces, or stoves, or other means of warming those old meeting-houses for a hundred and fifty years after the Colony was planted. ${ }^{1}$ This is not so strange as it seems, for the churches and cathedrals in Europe were not warmed until a time comparatively recent. Our forefathers had been accustomed to worship in cold churches in the Mother Country. ${ }^{2}$ Still those cold places of worship must

1 Dr. Dexter says : " The first church stove which I have seen mentioned in Massachusetts was in the First Church in Boston, I773." There is, however, a suggestion of an earlier one in the history of the First Church in Newton.

2 Any traveller can verify these statements. The old stone church in Grasmere, $c . g$. where Wordsworth was accustomed to worship for many years, has not to this day a chimney. It is not many years 
have been severe tests of the zeal and fidelity of the worshippers. President Porter remarks, "The breath of the worshippers of a cold winter morning would not unfrequently seem like smoke from a hundred furnaces, as it came in contact with the frosty atmosphere. The walls, which had been almost congealed into ice by the fierce northwesters of the preceding week, would strike a chill of death into the frame of many in the congregation, who had come ploughing through unbroken roads and unswept walks." 1 "Herein is the patience of the saints."

\section{VII.}

Of course the Puritan ministers regarded the public worship of God on the Lord's-day as of the first importance. The people were exemplary in their attendance, and the laws worship. which they enacted required all persons within their jurisdiction to go regularly to the religious services. To neglect this, exposed the neglector to a heavy fine. ${ }^{2}$ These laws were not peculiar to

since the first stoves were introduced into that church, and the smoke pipes are still carried through the roof. This is not uncommon in the parish churches of England. The heatingapparatus in the great abbeys and cathedrals is so modern that it contrasts strangely with the other work of the interiors.

1 Bibliotheca Sacra, I883, 3 Io.

2 General Laws, 83. Palfrey, vol. ii. 33: vol. iii. 49. Mass. Records, vol. iii. 317. Felt, vol. ii. 453 . 
New England. The laws of Virginia made the same requirement. So did the laws of England. This was in accordance with the spirit of that age. It was even provided by the laws of Massachusetts that on the recurrence of the mid-week lectures, all innkeepers and victuallers within one mile from the meeting-house should clear their houses during the time of service of all persons able to go to meeting. It was also provided that any person who should smoke tobacco within two miles from the meeting-house, going or returning from public worship, should pay a fine of twelvepence. So they carried out the injunction, "Keep thy foot when thou goest to the house of God."

The Lord's-day began at sunset on Saturday, according to the laws of Connecticut. ${ }^{1}$ But the The Lord's- laws of Massachusetts provided that day. persons employed to labor might stop work at three o'clock Saturday afternoon, and spend the remainder of the day in catechising their children, and in preparation for the Sabbath. Both these enactments imply that it was the custom to begin the Sabbath on the evening of Saturday. The early ministers of New England regarded the Sabbath as a time for the public worship of God, and for religious instruction. The people came together "at nine of the clock," for the morning service. In the early times, before they could 1 Felt, vol. ii. 33. Mass. Records, vol. i. 395. 
afford the luxury of bells, they were summoned by the beat of a drum. Sometimes the voice of the town-crier, or the blowing of a conch-shell, or of a horn, served instead of the drum. The old meeting-houses were crowded, for they were not too large, and the people had a mind to go.

Inside the doors, the most conspicuous object was the pulpit, with the things that belonged to it. In front of the pulpit, on a low platform, sat the deacons, facing the congregation. On a platform a little higher than the deacons sat the ruling elders. Above them, in the pulpit itself, sat the two ministers. This array of dignitaries, some of them, at least, in robes of office, looked down upon the congregation, and was looked up to by the people. "Our principal care and desire," says John Cotton, "is to administer the ordinances of Christ himselve in their native puritie, The order of and simplicitie, without any dressing or Services. painting of human inventions." 1 And so, leaving the traditional forms of worship, they conducted the services in this wise:-

First, "the bills which any of the neighbors put up, desiring a remembrance in the public prayers and praises were read."

Then, the pastor began with solemn prayer, continuing about a quarter of an hour.

After this, the teacher read and expounded a

1 Cotton's Way of the Churches. 
chapter in the Bible. For they would have no reading without "giving the sense." This exposition of the chapter was one of the leading parts of the service. It was generally a very thorough exposition, and continued a long time. It was one of the most instructive parts of the service.

Then a psalm was sung by the congregation, "whichever one of the ruling elders dictates." 1 In some churches, though not in all, it was the custom for the elder to read the psalm, line by line, ${ }^{2}$ in order that those who were not provided with books might be able to join in the singing. No instruchurch Music. mental music was allowed in the Puritan churches, partly because such music was very prominent in the services of the prelatical churches, and partly because it was believed to

1 Lechford, Plain Dealing, 44 .

2 From the beginning of the Reformation, the singing of psalms and hymns, by the people, was made a prominent part of the public services of religion. It has been said, that the Reformation among the German people was advanced quite as much by Luther's hymns, as by his sermons. Our fathers brought to New England a version of the Psalter made by Ainsworth of Amsterdam, which they used in their religious services for many years. About I640, the Bay Psalm Book was introduced into the churches. This was prepared by some New England ministers, among whom were Mather of Dorchester, President Dunster of Harvard College, Weld and Eliot of Roxbury. This was in use for about a century, passing through seventy editions. It did not contain the Te Deum, or the Gloria in Excelsis, but it did contain a metrical version of the l'salms, the Song of Solomon, and the Lamentations of Jeremiah.

In 1693 , an edition of Sternhold and Hopkins was published in Cambridge, and was used in the churches to some extent. 
be contrary to the word of God. ${ }^{1}$ But the people were able to sing the few tunes that were in use in the English churches when they came over. Cotton Mather, who is a good authority upon such a matter, states that "their way of singing was not with disorderly clamors, but in such grave tunes as are most used in our nation: it has been commended by strangers, as melodious and agreeable: - more than a score of tunes are heard regularly sung in our assemblies. The churches of New England admit not into their public services any other than the Psalms, Hymns, and Spiritual Songs of the Old and New Testaments faithfully translated into English metre. They did not favor the Te Deum, or any merely human composition." 2

1 Amos, v. 23.

2 Ratio Disciplinæ, 54-56. Palfrey, vol. ii. 41.

"The early settlers of New England," says Rev. Mr. Symmes, " used to sing by note, and there are many now living who learned to sing from their forefathers." Music was studied in Harvard College for many years after it was founded, and the ministers educated there were taught to sing. The music used in churches was written in their Psalm-books. The number of tunes thus written rarely exceeded five or six. The music was taken from Ravenscroft's collection, published in England in 1618 , which was the standard book for the churches in England and America for a long time. About $\mathrm{I} 690$, music began to be printed in this country, appended to the Psalm-book. Some of the tunes thus printed were Litchfield, Canterbury, York, Windsor, Cambridge, St. David's, Martyrs, Hackney, and Old Hundredth. They were printed in two parts only, and were accompanied by a few simple directions for singing.

Toward the end of the first century of New England history, the 
Our fathers did not favor church choirs. The singing was by the congregation for the larger part of the first century.

After the psalm came the sermon by the pastor. This was the great feature of the service. Its length was measured by the hour-glass, which commonly stood on the pulpit. The minister turned the glass when he began his sermon; and he was expected, on ordinary occasions, to draw his discourse to a close when the last sands were

decline in church music had become very perceptible. The cultivation of music had been neglected, and at the commencement of the eighteenth century few congregations were able to sing more than three or four tunes. The knowledge and use of notes had been long neglected, so that the few melodies in use became corrupted, until no two individuals sang them alike. "Every melody was tortured and twisted," says an old writer, "until the psalms were uttered in a medley of confused noises, rather than in a decorous song." "It is with great difficulty that this part of worship is performed, and with great indecency in some congregations, for want of skill."

About $\mathbf{1 7 2 0}$, a reformation was inaugurated. The ministers as usual took the lead, and preached and published excellent discourses upon the subject. Singing-schools were commenced about this time, and sacred music was taught by competent teachers. From these schools came church choirs. The objections to the use of instruments of music in church services were gradually overcome. This reform however was vigorously opposed. The question whether it was better to sing by note, or to sing by rote, was hotly debated. In some places the discussion was so warm as to interrupt the harmony of the churches. Several ecclesiastical councils were convened during the first half of the last century to consider that question. In the end, the better methods of singing were generally adopted, and musical cultivation in this country was rapidly advanced.

History of Music in New England, by George Hood; Palfrey, vol. ii. 40. 
running out from the glass. Yet there were instances when the glass was turned two or three times. To quote again, one of the old writers, "The pastor, bespeaking attention, reads a text, longer or shorter, as he pleases, from the sacred Scriptures; and then makes a sermon. He gives himself a liberty, either to preach over a Body of Divinity, in order,

Sermons of the Puritan Ministers. or to handle such doctrines and cases as he may judge most necessary. Care was taken not to weary the hearers, so that they should be dull at the evening assembly; so that ministers generally limited themselves unto about one hour." 1

The sermons of the early ministers of New England were not written, although they were carefully prepared. It is said that Mr. Warehan of Dorchester was the first who used written sermons in New England. But in the time of Cotton Mather the lise of written sermons liad become common.

The sermon being finished, the teacher makes a shorter prayer. After the prayer, another psalm was sung.

After these services of worship and of instruction were concluded, baptism was administered to children who were presented by their Christian parents. It was com-

Baptism and the Lord's Supper. mon to insist that all such baptisms should be in the meeting-house, and in the presence of the

1 Ratio Disciplinæ, 55-57. 
congregation. In most instances the children were presented within seven days from their birth, though they were sometimes presented earlier.

Once a month, the Sacrament of the Lord's Supper was administered, in connection with the morning services. It was very simple, conforming to the words of the New Testament. The ministers, with the other officers of the church, were seated at the table. After the prayer of consecration, the ministers handed the elements, first to those seated with them at the table, after which they were passed to the deacons, who distributed them to the communicants. They received them sitting in their usual seats. The minister who had not offered the prayer of consecration prayed after the elements had been passed. Then a psalm was sung, and the people were dismissed with the benediction.

This completed the morning services. The intermission was longer or shorter, according to the convenience of the people, though the more common hour for the evening service was two o'clock. At this service, the pastor began with prayer, as in the morning. Then a psalm was sung by the congregation. The minister who had preached in the morning, expounded the chapter in the afternoon, and the one who had expounded in the morning, preached in the afternoon. After the sermon another psalm was sung. 
When this was ended, one of the deacons arose and said: "Brethren of the congregation, now there is time left for contribution: Wherefore, as God hath prospered you, freely offer. Then they bring their offering to the deacon at his seat, and put it into a box of wood for the purpose, if it be money or papers. If it The offerings pose, if it be money or papers. If it in the be any other articles, they set it, or lay it down, before the deacons, and so pass another way to their seats again. In coming forward, they are careful to have the Majistrates, and chiefe Gentlemen first, and then the Elders, and all the congregation of men, and most of them that are not of the church, all single persons, widows, and women in absence of their husbands." "I have seen," says Lechford, "a faire gilt cup with a cover offered there by one, which is still used at the Communion. These moneys, and goods, the deacons dispose towards the maintenance of the ministers, and the poore of the church, and the church's occasions." The contribution finished, there follows the admission of members to the church, or hearing matters of offence, or other things, sometimes till it is very late. They sing a psalm at the close, and the pastor concludeth with a prayer and a blessing. ${ }^{1}$

1 The materials for this account of the way of worship of our fathers are derived from John Cotton, Lechford, Winthrop, Cotton Mather, and some others. 


\section{VIII.}

ThERE was a mid-week lecture in many of the churches. This was conducted much like one of

The the services on the Lord's-day. The Mid-week people were expected to attend it, as Lecture. they were to attend on the Sabbath. In Boston, and some other towns, the lecture was on Thursday; but it might be on any day of the week, so that in sections where the churches were not far apart, the people had the opportunity to hear the word preached every day. When John Norton was pastor of the Church in Boston, his reputation for eloquence and piety was so great that people used to come from the adjoining towns, sometimes even from places as far away as Ipswich, to hear him. In I639, there were so many lectures, and so many persons neglected their business for the purpose of attending them, going often two or three days in a week, that the General Court sought a conference with the elders "to consider about the length and frequency of church assemblies," lest they should seriously interrupt the work of the people.

The old writers make frequent references to these week-day lectures. John Cotton was preaching a series of expository lectures upon the Book of Revelation, on Thursdays, about I640. This 
series extended through several years, and parts of it were published in London, from notes taken by one of his hearers. It was the method of Mr. Cotton in all his preaching to go through the books of Scripture in the way of exposition, and it is stated that in the course of his ministry he had expounded almost every one of the books of the Bible.

There are records, more or less complete, of the parochial work of the early ministers. In I64I, the General Court requested the Their Paroelders to "make a Chatechisme for the chial work. instruction of youth in the grounds of religion." 2 "Milk for Babes," by John Cotton, was used for more than a century, and it was always printed in the earlier editions of the "New England Primer." Its full title was "Spiritual Milk for American Babes drawn out of the Breasts of Both Testaments for Their Souls' Nourishment." Later, the "Westminster Shorter Catechism" was introduced; and this supplemented the less ambitious teaching of Mr. Cotton. Some of the pastors were wont to catechise the young people on the Lord's-day, in the afternoon, before the sermon. Others gathered the children at their

1 Cotton, Way of the Churches. Winthrop's History of New England, i. 324 (folio p. 390). Lechford, 51, notes. Cotton Mather, Ratio Disciplinæ, 63 .

${ }^{2}$ Records of the Colony of Massachusetts, vol. i. 328. 
own houses, on some week-day, for the same purpose. Others went from house to house to catechise the children. There were also more public recitations of the catechism. So that the careful and systematic teaching of religious truth to the young was a great part of the work of the early ministers.

The visiting of the sick, and of the aged and infirm, and the pastoral care of the families that made up the congregation, was then, as now, a great part of the work of the ministers. Those visits were more formal and professional than such visits are in our times. But there is abundant evidence that they were full of kindness as well as fidelity, and that they supplemented in an admirable way the other parts of pastoral labor. ${ }^{1}$

\section{IX.}

THE churches that were organized by the Pilgrim ministers were strictly Independent Churches. The Pilgrims had followed that way at Scrooby, and in Holland, and they naturally organized the Church in Plymouth according to their old models. The Puritans, after a little time, adopted the same model.

Within four weeks after the arrival of Higginson and Skelton at Salem, in 1629, a day was set

1 Cotton Mather's Ratio Disciplinæ, ro6-I I I. 
apart for the choice of a pastor and a teacher. Mr. Skelton was chosen pastor, and Mr. Higginson teacher. Mr. Higginson, and three or four of the gravest men, laid their hands on Mr. Skelton's head, and prayed. So he was inducted into his office as pastor. Then, by a similar religious service, Mr. Higginson was set apart for his office as teacher, Mr. Skelton laying his hands upon his head. After this had been done, Mr. Higginson drew up a Confession of Faith, and a Church Covenant; and copies of the same were delivered to thirty persons who were to constitute Form of the Earliest 0rganized Churches in New

England. the church. Messengers were sent to Plymouth to ask the Pilgrim Church in that place to send delegates to witness the further proceedings. At the day appointed the two ministers prayed and preached; thirty persons assented to the Articles of Faith and Covenant; the ministers were again ordained, by the imposition of the hands of some of the brethren appointed by the newly organized church. Governor Bradford and the other messengers from the Church in Plymouth gave to the new church the hand of fellowship, and thus the second church in New England was organized. The other churches within the Puritan Colony were organized in a similar way. ${ }^{1}$

1 Morton's New England Memorial, 99. Prince's History of New England (edition of 1736), 9I-92. 
In the first generation of New England history, a church which was fully equipped had two ministers, one the pastor, and the other the teacher. Both of them were preachers. Both were called elders, and both were authorized to administer the Sacraments. The special function of the pastor was public and private exhortation, and that of the teacher was doctrinal and biblical explanation. In practice, the two offices were much the same, the pastor preaching one part of the day, and expounding the other, and the teacher also preaching once, and expounding once each Lord's-day. The pastor was, however, the leading officer of the church. Both gave themselves to parochial work. Each church had, also, one or more ruling elders, who shared with the ministers the responsibility for the discipline of the church. The church had also one or more deacons, who had charge of the finances of the church, and of providing for the poor. In later times, however, this large number of officers, suggested perhaps by the various ranks in the ministry of the Episcopal Church, was found to be unnecessary. The offices of pastor and teacher were united in a single minister, and the ruling elders were dispensed with. ${ }^{1}$

People in the Episcopal Church have sometimes questioned the validity of Non-Episcopal

1 Cotton's Way of the Churches. Lechford's Plain Dealing. 
ordination. But among the Puritans, the question was whether Episcopal ordination was valid. They held that the only valid call to the ministry was the call of Christ through a congregation of His people. So that, although their ministers had been ordained years before, by the bishops and presbyters of the Church of England, they held that their office had terminated with the end of their pastorate. The doctrine of the permanence of the office of the ministry, aside from the pastorate of a local church, they held to be nothing short of a Romish heresy. One who ceased to be a pastor was no longer a minister. He could enter the ministry again only by the call of a church, and a new ordination. So that it was not so much a disowning of Episcopal ordination, as the opinion that the validity of the ordination had passed away when the pastorate ended. If the call of the church was the only true call to the ministry, it followed that it was proper for the church to set apart the man of their choice to the sacred office.

They also limited the functions of the pastor by the bounds of his parish. It was provided by law, in Massachusetts, that if any minister should preach, or administer the Sacraments, outside his own parish, except by the invitation of the settled minister of that place, he should lose his salary. It was also provided, by law, that if any person, 
not a settled minister, should exhort in any parish, without the invitation of the pastor, and a majority of the congregation, he should be put under bonds of one hundred pounds to keep the peace. The practice of private members speaking in religious assemblies, without a special invitation from the officers of the church, was not encouraged. ${ }^{1}$ So carefully did the Puritan legislature protect the privileges of the settled ministers! It is even related of a Puritan minister, who was making a voyage across the Atlantic, that when he was asked to baptize a child, which was at the point of death, he declined to do it, because, as he said, there was no regular congregation worshipping in that place.

\section{$\mathrm{X}$.}

IT only remains to speak of the mistakes of the early Puritan ministers. They were laying foundations. They were the builders of states. They had few precedents to guide them. It is not surprising that they made mistakes. Those mistakes stand out distinctly in their history. It is easy to overrate them. Some recent writers have given so much prominence to these mistakes that they have failed to do justice to the Puritan spirit

1 Lechford's Plain Dealing, I2-16, and 43, note. Palfrey, vol. ii. 39 . 
and work. Those mistakes were the mistakes of great men, and of sincere and honest men. Their honesty was shown in their readiness to correct their errors.

The Puritan ministers were limited by their environment, as we are by ours. They lived in times of conflict; and it was their mis- The Mistakes sion to stand for the truth, and to suffer of the Early for for it, as the heroes of faith. Their ters. fidelity to the truth made them positive men. Such men are liable to push a point too far. They were not far enough from the experiences of persecution to give a hospitable reception to the new truth that was breaking from the Word of God. It is too much to require that the opinions and the methods of such men should be up to the standard of the last decade of the nineteenth century. But the Puritan ministers, with all their limitations, were men of remarkable good sense. If they made mistakes, they had enough of Anglo-Saxon sagacity to discover and correct them. They made progress in building the Church and the state in the New Vorld by rectifying their errors.

For example, in the earlier years of the Colony of Massachusetts, they would have no public reading of the Bible, unless accompanied by an exposition. The reason was, that it was important, at that time, to guard against a 
tendency to a formal and perfunctory service in public worship. They would have the reader give the sense, that the worship might be intelligent. But in the course of time they learned that it was quite possible to read the Scriptures intelligently, and devotionally, without an exposition; so that, before the close of the century, the custom of reading the Scriptures in public worship, without note or comment, had become common. ${ }^{1}$

Another illustration of the progressive spirit of the Puritan ministers is found in the history Their Progres- of their method of conducting the sersive spirit. vices at funerals. They would have nothing that was suggestive of prayers for the dead. One of the old Puritan writers said: "All prayers, either over or for the dead, are not only superstitious and vain, but are also idolatry, and against the plain Scriptures of God." 2 And so the old ministers would not consent, on any ground of sentiment or of feeling, to follow the English customs with respect to funerals, because they apprehended that those customs tended toward the practices of the Church of Rome. To such a point had they come in their opposition to the superstitions of that Church, that, for many years, "nothing was read at burials, nor

1 Ratio Disciplinæ, 65.

2 J. Canne's Necessity of Separation, 1634, 112. Ratio Disciplinæ, I 7 . Lechford, SS. 
any funeral sermon made, but all the neighborhood, or a good company of them, came together, by the tolling of the bell, and carried the dead solemnly to his grave, and then stood by him while he was buried. The ministers were most commonly present," but had no part. But all this was too unnatural, and too far from the spirit of the New Testament, to be continued by such Christians as they were. So that, we find, as their dread of the prevalence of Romanism became less, they gradually adopted the funeral customs that have been common among Protestant Christians. The first instance, so far as we know, of prayer at a funeral, in Massachusetts, was at the burial of Rev. William Adams, of Roxbury, in $\mathrm{I}_{6} 68_{5}$. Judge Sewall has noted in his diary, that, "Mr. Wilson, the minister at Medfield, prayed with the company before they went to the grave." In the earlier years of the eighteenth century, according to Cotton Mather, it had come to be the ordinary practice to have religious services at funerals.

The celebration of marriage was also by a magistrate, in the earlier years of our history. The reason was that the Church of Rome had exalted marriage to the rank of a Sacrament. As Protestants, the Puritans made their protest against this as emphatic as possible. So they treated marriage as purely a civil contract, and sent the parties who were to be married from the 
church to the town-house. The ministers were themselves married by magistrates. But they were in error in saying that marriage was only a civil contract. The people gradually dropped this extreme theory, and began to connect marriage with the Church and its religious services. By the time of Cotton Mather, marriage was commonly celebrated by the pastors, and was recognized as an institution which had close connections with religion. But the use of the ring in marriage was objected to for many years more, as a Popish superstition. ${ }^{1}$

Our Puritan fathers made it a matter of conscience to call the days of the week by numerals, and to call the months in the same way, as the Quakers do to this day. It was a singular scruple which they had, and it had its origin amongst the Lollards, and the Anabaptists, from whom the Quakers and some other Protestant sects came. They thought it was giving honor to the heathen gods, and to pagan worship, to call their days Sunday, or Monday, or Tuesday, or Wednesday, or to call their months January, or March, or May. But while this scruple has been so tenacious among the Friends, that even Mr. Whittier continued to follow it as long as he

1 Felt, vol. i. 59. Lechford, S6, note. Ratio Disciplinæ. R. C. IVinthrop says, vol. ii. $3^{82}$, "The earliest record of a marriage by a minister, in Massachusetts, is dated I686." 
lived, our Puritan fathers had laid it aside before their colonies had completed their first century.

The Puritan ministers had very strong prejudices against the observance of the ancient fasts and festivals of the Christian year. The observance of Christmas and Easter was regarded by them as "one of the earliest apostacies and superstitions of the primitive times." They would have no regularly recurring holy-days except the Sabbath. ${ }^{1}$ And yet, as deeply religious people, they felt the need of such days. So they appointed from time to time Days of Fasting and Prayer, at the season of planting, or at other seasons ; and, after the harvest had been gathered, or whenever any special blessing had been given to them, they appointed Days of Thanksgiving. The observance of these days was required by law, just as the observance of the Sabbath was required." In the earlier periods of our history, these days were religiously observed. These occasional fasts and thanksgivings long ago became stated days. The objections to stated days of fasting and thanksgiving have been overcome. The laws which forbade the observance of Christmas and Easter were long ago repealed; and those days have steadily grown in favor with the best people among the sons of the Puritans,

1 Ratio Disciplinæ, I86. John Cotton's Way of the Churches.

2 Palfrey, vol. ii. 43,44 . Fasts and Thanksgivings of New England, by IV. DeLoss Love, Jr., rS95. 
until it has come to pass that the Puritan Thanksgiving itself seems to be giving place to the Christmas of the Christian centuries, and the annual Fast-day has already been discarded in the State of Massachusetts. It may be that it is only a question of time when Good-Friday will take the place of the New England Fast-day. I do not doubt that if Governor Winthrop and John Cotton were living to-day they would heartily approve the change.

\section{XI.}

These illustrations of the progressive spirit of the Puritan ministers relate to matters which are perhaps of minor importance. But the same spirit was shown in much more important things.

In the first years of the Colony of Massachusetts, it was ordered by the General Court that " no man The suffrage shall be admitted to the freedom of this Limited to body politic, but such as are members
Members of

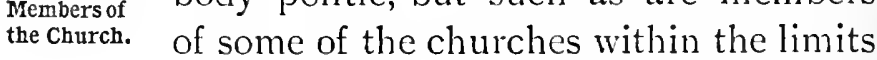
of the same." In this way the Puritans sought to limit the citizenship to the best men. But there were indications almost immediately that the propriety of a religious test was questioned, especially by the more progressive men among the ministers. Thomas Hooker wrote a letter to Governor Winthrop, in which he said, "In matters which concern the common good, a general council, chosen by 
all, to transact business which concerns all, I conceive most suitable to rule, and safe for the relief of the whole." With this view of the true basis for the right of suffrage, Mr. Hooker, in I6 35 , led a company of his friends to found a new colony on the banks of the Connecticut. At the first session of the General Court of the new colony, Mr. Hooker preached a sermon in which he said, "The foundation of authority is laid in the free consent of the people;" " the choice of public magistrates belongs unto the people, by God's own ordinance;" ... " they who have power to appoint officers and magistrates, have the right to set the bounds and limitations of the porrer and place of those who are called." Thus it was that this Puritan minister laid down the principles which underlie the Constitution of the United States, a hundred and forty years before the American Revolution. These principles were embodied in the written constitution of the Colony of Connecticut, which was adopted in 1639. That constitution did not impose any religious test to limit the admission of adult male citizens to the right of suffrage. These principles had a great influence in Massachusetts. In I 647, the General Court voted that those who were not members of the churches might vote for selectmen, and on questions relating to the assessment of taxes, and that such persons might be chosen to fill certain offices in the towns. 
In I669, under some pressure from the king, the Court was induced to repeal the law which limited the suffrage to communicants in the churches. And when, in 1692, the Provincial Charter from William and Mary was received, the change in public opinion had been so decided that there was very little opposition to its provisions, which extencled the suffrage to all qualified citizens, without reference to their ecclesiastical relations. ${ }^{1}$

It is hardly necessary to mention the wellknown fact, that the Plymouth Colony never imposed any religious test as a qualification for the suffrage. There were persons in that Colony who did not agree with the views of the majority, but some of these persons were voters, and were admitted to a prominent part in the administration of the Colony.

The next illustration touches a more serious charge. The Puritans of Massachusetts have been called intolerant, because they sent out of the Colony a number of persons whom they regarded as disturbers of the peace. They claimed the right, in the first years of the Colony, while their institutions were in the forming state, to shut out those who would cause divisions among the people, and those who had shown themselves restless and uncomfortable members of society. In the carly years of the Colony, the Browns -

1 Mass. Colonial Records, vol. i. 197 ; vol. iv. II 
one of them a merchant, and the other a lawyer were shipped back to England, because they attempted to gather a congregation, in Salem, which should use the Book of Common Prayer in the worship of God, after the manner of the Episcopal Church. Eight or ten other persons, whose presence in the Colony was found to be inconvenient or dangerous, were sent away at various times.

The most noted of this class of persons was Roger Williams, who was certainly one of the greatest of the Puritan ministers, and whose services in behalf of religious liberty have given him a place among the foremost men of that great age. He arrived in Boston, in $16_{3} \mathrm{r}$, when the Colony was still young, and weak, and when he was himself hardly thirty years of age. He had taken the degree of Bachelor of Arts at Cambridge, in 1626 ; and he had probably been a clergyman in the Church of England. He says that Bishop Laud pursued him out of the land. Soon after he arrived in Boston, he was invited to take the place of one of the pastors, for a few months. He declined the courteous request, because, Roger as he said, he did not "dare officiate to williams. an unseparated people." By this he seems to have meant that the church in Boston was not radical enough in its separation from the Church of England. After this he preached a few months in Salem, then two or three years for the Pilgrims 
in Plymouth, and then, leaving them somewhat abruptly, after setting forth, as Governor Bradford tells us, certain strange opinions, which stirred up controversy, he went back to Salem, and preached some years in that town. Some of the people of Salem were inclined to adopt his opinions, while a large number dissented from them. The magistrates came to look upon him as a disturber of the peace, and an enemy of good order in the young Colony. He taught that the charter of the Colony was of no force or authority; that the people had no title to their lands; that it was unlawful to join in worship with any person who was unregenerate, though that person might be a member of one's own family; and that it was unlawful to administer the oath to one who was not a Christian. The churches of the Colony, he said, were idolatrous and corrupt, and their ministers were false, and hirelings. ${ }^{1}$

Great efforts were made by $\mathrm{Mr}$. Cotton and Mr. Hooker, to convince Mr. Williams that he was in error in these severe judgments, and to induce him to withdraw his accusations, but in vain. Iinally the General Court, after long delay, and several hearings, decided that Mr. Williams, having divulged new and strange opinions, against the

1 Palfrey, vol. i. 4I3. Winthrop's History, vol. i. 6I, I I I. Mass. Colonial Records, vol. i. 77, \$2-86, 9I, 108. Dexter's As to Roger Williams, 3, note. Bradford's History. 
authority of the magistrates, and of the churches, should depart out of this jurisdiction, within six weeks. The time was afterwards extended to six months, and Mr. Williams finally left the Colony. His great reputation was made after he was himself at the head of a colony. An independent position made him conservative and constructive. As he grew older and more mature, he developed a character which has secured to him the admiration and respect of all the friends of religious liberty. After he left Massachusetts, he became a Baptist, and was baptized by immersion; and he did a great deal to give influence and usefulness to that religious denomination. But that was not the reason that he was required to depart out of the Colony.

It is pleasing to know that the sentence of the General Court against Mr. Williams was revoked some forty years later. The vote, which is preserved in the Archives of Massachusetts, ${ }^{1}$ makes honorable mention of the services which $\mathrm{Mr}$. Williams had rendered. by his influence with the Indians, in time of war, and by his respect for the authority of the Colony in several services desired of him; and also of the misfortunes which he had suffered in his old age, on account of the burning of his house in Providence by the Indians; and it declares that the "sentence of restraint

1 Massachusetts Archives, vol. x. 233. 
174 THE PURITAN IN ENGLAND AND NEW ENGLAND.

from coming in to the Colony " is repealed, and that Mr. Williams "shall have liberty to repair into any of our Towns for his security and comfortable abode during these Public Troubles."

\section{XII.}

The heaviest charge against the early Puritan ministers relates to the part which they had in the prosecution of the Quakers, and in the most cruel and atrocious proceedings which grew out of the detusion concerning witchcraft. The first occurred between I656 and I66I, when the Colony of Massachusetts was about thirty years old; the second between 1690 and 1692 . No reasonable excuse can be made for the extreme folly and wickedness of those proceedings. It seems unaccountable that men with so much of English sense and courage should have been thrown into a panic by the presence of a small band of Quakers in a colony which had at that time a population of thirty or forty thousand people. It is no valid excuse for the Puritans to allege that the Quakers were persecuted in England as well as in New England. It is true that during the years when there were twenty or thirty Quakers in jail in Nerv England, there were more than a thousand of them imprisoned in Great Britain. The whole number who were fined, imprisoned, or scourged in the 
two colonies of Massachusetts and Plymouth may have been sixty; while the number who suffered in that way in England was between three and four thousand; and three hundreel and Persecution of thirty-eight died in English prisons. ${ }^{1}$ the Quakers.

But we have a right to expect a larger charity among a people who had themselves endured persecution. It is true, however, that the Puritans dealt with the Quakers simply as intruders into their Colony. They claimed the right to forbid them to enter their bounds; and they always offered them a free pardon, even after sentence, if they would depart from the Colony. When the law was passed in Massachusetts which provided for inflicting the penalty of death upon Quakers found in the Colony under certain circumstances, it was vigorously opposed by a numerous party, which included both ministers and laymen, and it was finally enacted by a majority of only a single vote. It is also true, that each of the four persons who were put to death under that law came into the Colony from abroad, after he knew of the existence of the law. They came expressly to defy the penalty. Each of them was offered his liberty if he would engage to leave the Colony. They voluntarily laid down their lives as a testimony against an unrighteous law, and their death led to the

1 Encyclopædia Britannica, vol. xx. 148, 9th ed. Palfrey, vol. ii. $440-445$, note. 
repeal of the law. In this case, as in so many others, the victory was with the persecuted party.

Thirty years later, another epidemic of folly swept over the New England colonies, which Ted witchcraft in to a multitude of horrors, and the juNew England.

dicial murder of about twenty persons. The Puritans had always believed in the existence of what is known in history as witchcraft, as most persons who lived in the seventeenth century did. When it was alleged that there were persons in Satem, and various other places, who had entered into a league with the Devil to torture and kill their neighbors, they seem to have taken leave of their senses, and given themselves up to a carnival of folly. The history of that delusion is undoubtedly the darkest part of their record.

And yet it is an error to suppose that our fathers were peculiar in this thing. They only adopted the common belief of their times. The atrocities in New England were much less than those in - Old England. The state trials of England show that Chief Justice Hale, and others among the most eminent jurists in that country, believed that witchcraft was a crime to be punished by law. In the years when witches were hung in Massachusetts, a much larger number were put to death in Great Britain. It is related that the bull of Pope Inno-

1 Encyclopiedia Britannica, Art. Witchcraft. Palfrey, vol. iii. $124-125$. 
cent the Eighth against witchcraftcaused the death of a hundred thousand persons in Germany alone. The story of man's inhumanity to man is not limited to Massachusetts. The English statutes against witchcraft were not repealed until fifty years after the superstition had passed away from New England. It can be fairly claimed, in behalf of our fathers, that the madness was past in about two years, instead of lasting for generations, as it did in so many other countries; and that the number of victims, when compared with the number who were put to death elsewhere, was small. Moreover, those who had been led to participate in the atrocious acts of the epidemic of cruelty, were among the first to discover the folly and wickedness of the whole thing. The confessions which they made were very full, and as public as their offence had been.

\section{XIII.}

Another illustration of the progressive tendency among the early New England ministers is to be found in the history of their Church Polity. The first churches were strictly independent. The ministers were jealous of any act which implied that a neighbor The Polity of the Early Churches. church had a right to influence another church. In the earliest years the churches exercised their right 
to ordain their own officers, without the advice or help of their neighbors. Thus they lost sight of the fellowship of the churches, in the one kingdom of our Lord. They followed the same course that the English Independents have followed, whose churches were said by one of their own divines to be "like so many ships launched singly, and sailing apart and alone in the vast ocean of these tumultuous times, exposed to every wind of doctrine." 1 There was no more important work done by the early Puritan ministers than the evolution of the Congregational Church Polity from the Independency of the first years of the Colony. It was by experience and free discussion that they learned to limit the tendency to the isolation of the local church, by the principle of fellowship.

John Cotton and Thomas Hooker seem to have been the leaders in the movement to supply the defects in the ecclesiastical system. Both of them published important works designed to lead toward a better Polity. The movement was strengthened by the apprehension that the Presbyterian party in England designed to impose their system of church government upon the colonies. It was felt that the separate and isolated churches in New England were in no condition to resist such an effort. The General Court of Massachusetts

1 The Savoy Divines of 1658 , quoted by Palfrey, vol. ii. ISo. 
therefore invited the churches in all the colonies of New England to send their elders and messengers to a synod at Cambridge "to establish and settle the right form of government and discipline for the churches." The synod met in 1646 , and, after a short session, adjourned for a few months, and then adjourned a second time, so that the final session was held in 1648 . All through the two years, the discussion of principles was going on among the churches, so that in the end a good degree of unanimity was secured.

The Cambridge Platform which the synod finally adopted was designed to introduce order and unity, and to create a system capable of more efficient action than had been provided for by the earlier methods. The synod, in seeking for a bond of union, discarded the methods of the Presbyterian and Episcopal churches, and adopted the system of ecclesiastical councils, which had been growing in favor among them for a long period. The council, as they conceived of it, was not to be a permanent body, but to be convened for special occasions, and to be made up of ministers and delegates from the churches of the vicinity; and its existence terminated when the business for which it was called had been done. Its decisions were not authoritative, but " had so much weight as there was weight in the reasons for them." The platform recognizes and defines 
the rights of the local church, and it denies to councils the power of discipline by authority. But it encourages the calling of councils to consider and advise in matters of common interest. It allows the ordination of church officers by officers of other churches, assembled in mutual councils, thus relaxing the ancient rule. "It belongeth unto synods and councils to debate and determine controversies of faith, and cases of conscience, to clear up from the Word directions for the worship of God, and for the good government of the church, to bear witness against mal-administration and corruption in doctrine or manners in any particular church, and to give directions for the reformation thereof." 1

This platform has not been by any means a fixed rule of procedure. As it was itself the result of the development of principles, so its provisions have been modified and improved as the experience and needs of the churches have required, as they have spread beyond the limits of New England into all parts of the country. But the Cambridge Platform has maintained its place as an ancient and valuable standard among the Congregational churches for two hundred and forty-eight years. Its influence in securing the stability and the steady growth of the Puritan churches has

1 Historical Preface to the Cambridge Platform. Palfrey, vol. ii. $165-186$. 
been very great. It still holds a place of honor among them, and is one of the finest monuments of the wisdom and piety of our fathers.

\section{XIV.}

THE right of private judgment, that leading principle of Protestantism, is the source of most of the progress of modern times. The Puritans, in the exercise of this right, had thrown aside a great body of traditions from the Middle Ages; and they had put the ocean between themselves and the old societies and governments and churches, that they might work out freely their convictions in a new church and a new commonwealth. Every man of them felt that it was his right and duty to judge for himself in respect to all matters of truth and duty. It is an error to suppose that the Puritans were content to take their opinions from their ministers, or that the ministers themselves were agreed in respect to all points of faith or practice. The spirit of inquiry possessed all minds. New opinions were springing up every day. One of the synods found it necessary to condemn eighty-two errors that had been set forth by some among them. There could be no more striking illustration of the independent thinking of our fathers. Mr. John Fiske calls this tendency rationalism, and he says, "The conse- 
quences of this rationalistic spirit have been very far-reaching. In the conviction that religious opinions must be consonant with reason, and that religious truth must be brought home to each individual by rational argument, we may find one of the chief causes of that peculiarly conservative yet flexible intelligence which has enabled the Puritan countries to take the lead in the civilized world of to-day." 1

These statements of Mr. Fiske lead towards the true philosophy of New England history. Our Puritan fathers felt bound not only to interpret the Bible for themselves, but to test all principles and institutions by their reason and conscience. This habit of mind made them the most original and progressive men of their time. They were not hiclebound conservatives. They proved all things, and held fast that which was good. The New England spirit has been developed from the thinking and the devotion of those heroic men, planted in this new world, where they were free to build according to new patterns, bringing out of their treasure things new and old.

1 Beginnings of New England, I49. 
IV.

William Pynchon, Gent. 


\section{William Pynchon, Gent.}

$\mathrm{I}^{\mathrm{N}}$ writing of the early Puritan ministers of New England, it has been necessary to speak of a great many persons besides the ministers. For the ministers were closely connected with all the public men of the colonies, and with the social and political interests of the people. So that we have already seen what sort of men the political leaders of the people were; how they lived, and what ideals they were working out. The picture of Puritan life, however, will be more complete, if we study the lives of some of those who were not ministers. There were men in the colonies who guided the people in working out their principles, as Eliot and Hampden and Pym had the Great led the Puritans in the Mother Coun- $\begin{aligned} & \text { Puritan } \\ & \text { Governors }\end{aligned}$ try. We think at once of Governor and statesmen. John Winthrop, and his son of the same name, the Governor of Connecticut; and of the more conservative Governor Dudley, of Sir Henry Vane, also a Governor of Massachusetts, and of William Bradford, Governor of Plymouth, 
and his successor Edward Winslow. But the lives of these men have been often written, and very little that is new remains to be said about them.

\section{I.}

I HAVE chosen, therefore, to write of another man of affairs, of the Colonial age, who is not so well known as some of the other men, though he stood in the front rank among the founders of Massachusetts. William Pynchon ${ }^{1}$ was a Puritan of the Puritans, who came to New England with John Winthrop, in 1630 . He was one of the men who signed the notable agreement at Cambridge, August 16, 1629, with Winthrop and Dudley and william Isaac Johnson and eight others, which Pynchon. led the way to the settlement of New England. He was an original member of the Massachusetts Company, formed in England, and was one of its officers. He was the representative of an ancient and wealthy English family.

"The first of the Pynchon family," ${ }^{2}$ says President Thomas R. Pynchon, D.D., now of Trinity College, Hartford, Conn., "came to England with the Conqueror, and had a grant of manors in Lincolnshire. Thence they drifted, after some generations, into Northamptonshire, where W. Pynchon

1 See the frontispiece for his portrait.

2 MS. letter from President T. R. Pynchon, dated Trinity College, Hartford, March 4, I $\$ S 6$. 
resided, who was the grandfather of Henry Chichley, Archbishop of Canterbury, who flourished in the time of kings Henry Fourth, Fifth, and Sixth, between I4I4 and I443. From Northamptonshire they passed into Essex, and had property at Writtle, near Chelmsford. The church of that town, a noble building, has in its chancel many fine monuments running through several generations of the family." Nicholas Pynchon was sheriff of London, in 1532. His son John, of Writtle, Essex, married Jane, heiress of Sir Richard Empson, one of the ministers of Henry the Seventh. John Pynchon died in $\mathrm{I} 573$, leaving six children. His second son, John, settled in Springfield, Essex, near Chelmsford. His son William, of whom I am to write, was born, probably in Springfield, about 1590. The date of his birth is determined by an inscription ${ }^{2}$ on his portrait, now in possession of the Essex Institute, at Salem, which indicates that the portrait was painted in 1657 , and that his age was sixty-seven years.

William Pynchon, gent, as his name is always written in the records of the Colony, was a man of fortune, well versed in affairs, and well educated. It is said that he was not a graduate from the university; but his works show that he had some

1 Heraldic Journal, No. 14, April, I866, quoted in Records of the Pynchon Family.

2 "Guil. Pynchon armg. Effigies. | Delin. Anno Dom. I657. | æt. 67." 
knowledge of the Latin, Greek, and Hebrew languages, and a wide acquaintance with the theological literature of his time. He was one of the patentees named in the Charter of the Colony of Massachusetts Bay, from Charles the First, which bears the date of March 28, I628. ${ }^{1}$ He was also named in the same charter one of the eighteen Assistants, and was connected with the government of the Company before it was transferred to this side settlement of of the Atlantic by the notable vote of Roxbury. its members. He was the leader in the settlement of Roxbury, and one of the founders of the first church in that town. ${ }^{2}$ He was engaged in business, perhaps as a merchant. While at Roxbury he was for some years Treasurer of the Colony, and was elected, from year to year, one of the Assistants. He was early licensed as a furtrader. In 1632 , he paid twenty-five pounds into the treasury of the Colony for his license as a furtrader. The same sum was paid each year until I635, when the General Court remitted one fifth of the amount, probably because the trade had become less lucrative.

\section{II.}

IT is not easy to understand why it was that, within five or six years after the settlements near

1 Bancroft, vol. i. 265, 28r. Mass. Records, vol. i.

2 Hist. Boston, vol. i. 40I-4I I. 
Boston were begun, the people in a number of these settlements were moved by a common impulse to go further west. The reasons given, says Winthrop, ${ }^{1}$ were their "lack of accommodations for their cattle, so that they were not able to maintain their ministers, nor could receive any more friends to help them; and also the Plant a New Colony. fruitfulness and commodiousness of Connecticut, and the danger of its being possessed by others," Dutch or English; and, what is always the decisive reason with persons seized by the western fever, "the strong bent of their spirit to remove thither." Cotton Mather says, "It was not long before the Massachusetts Colony was become like a hive overstocked with bees, and many of the new inhabitants entertained thoughts of swarming into plantations extending further into the country." "The Colony," he says, " might fetch its description from the Scripture: "Thou hast brought a vine out of England; Thou hast cast out the heathen and planted it; Thou preparedst room before it, and didst cause it to take deep root, and it filled the land.' But still there was one stroke wanting, to wit, 'She sent forth her branches unto the river,' whereupon many of the planters, belonging especially to the towns of Cambridge, Dorchester, Watertown, and Roxbury, took up reso-

1 Winthrop's History of New England, vol. i. 140.

2 Quoted by Dr. Holland in Hist. of WVestern Mass., i. 20. 
lutions to travel an hundred miles westward from those towns for a further settlement upon that famous river, the report of which had made a little Nilus of it." All of which means, that Boston, Cambridge, and the rest were full, as the people thought, and they were already feeling the stirrings of that wonderful instinct which in two centuries and a half has belted the continent with Puritan populations, which stretch already as far as the Massachusetts charter gave a title, even to the western sea.

The I 4 th of May, I $634,{ }^{1}$ the General Court granted leave to the inhabitants of Newtown "to remove their habitations to some convenient place." On the 6 th of May, I6 35 , it was voted to grant liberty to the inhabitants of Watertown, and to the inhabitants of "Rocksbury to remove themselves to any place they shall think meete, not to prejudice another plantation, provided they continue still under this government." That same year a company, or several companies, settled on the Connecticut River within the present limits of Connecticut. In I635, two men, John Cable and John Woodcock, were sent by Mr. Pynchon to the Connecticut River to build a house for the new plantation. It is probable that Mr. Pynchon himself had before this crossed the country, to the valley of the river, and selected the place for the settlement. 


\section{III.}

IN the spring of $\mathrm{I}_{3} 6, \mathrm{Mr}$. Pynchon and seven other men made their way through the wilderness, following, it is supposed, the Bay Path, The springfield so called, and began a new plantation. Colony, I636.

Their goods were sent by water, in Governor Winthrop's vessel, - the "Blessing of the Bay," which left Boston, April 26th. We ride to Springfield, over almost the exact route of the Bay Path, in less than three hours. The pioneers were perhaps a week cutting their road through the forest, following, for a part of the way, an Indian trail. The date of their arrival is not known, but on the I $4^{\text {th }}$ of May they subscribed an agreement, which contains fifteen articles, and which was clesigned as the fundamental law of the Colony. It gives it the name of the Plantation of Agawam, spelled in the agreement Agaam, according to the pronunciation of the Indians of the vicinity. The first article provides for the settlement of a "Godly and faithful minister," "with all convenient speed, with whom we propose to joyne in church covenant, to walk in all the ways of Christ." ${ }^{1}$ The second limits the number of families to forty, or by general consent to fifty at the utmost. The others provide for the allotment of land to the

1 Judge Morris's Address, I 876, Appendix. 
various settlers, and for defraying the expenses of the settlement. It was stipulated that no man except Mr. William Pynchon "shall have above ten acres for his house lot." On laying out the land, the general course was to "allow each inhabitant a house lot on the west side of " what is now called Main Street, "eight rods wide, from the street to the river; a like width in the meadow in front of his house, to the foot of the hill; and a wood lot, of the same breadth, extending, at first eighty, and afterwards an hundred rods, nearly to the top of the hill ; and, when practicable, an allotment in the intervale, on the west side of the River, of the same width, and, as near as might be, directly against his lot." 1

Mr. Pynchon was the magistrate of the Colony, at first under a general commission from the Mr. Pynchon General Court, dated March 3, I636,

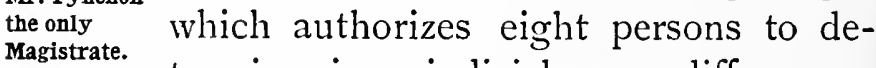

termine, in a judicial way, differences, and to inflict corporal punishment, or imprisonment, or to levy fines, in various plantations on the Connecticut River.

There is on record, at the Registry of Deeds in Hampden County, ${ }^{3}$ a paper which conveys the Indian title to the lands, on both sides of the river

1 Address by George Bliss, March 24, 1828 .

2 Massachusetts Colonial Records, vol. i. I70-I 7 I.

3 Dr. Holland's History, vol. i. 29. 
for four or five miles, to William Pynchon, Esq., Mr. Henry Smith (his son-in-law), and their heirs and associates. It is dated July 15,1636 , and is signed by thirteen Indians, by their marks. The consideration acknowledged in the deed is eighteen fathom of wampum, eighteen coats, eighteen hatchets, eighteen hoes, and eighteen knives, besides certain presents made to some of the chiefs.

The year following the settlement, the people secured the services of Rev. George Moxon, and under him they formed a church. ${ }^{1}$ Mr. Moxon had received Episcopal ordination in England. He was a graduate of Sidney College, Cambridge, and took his degree of A.B. in 1623 . He was a personal friend of Mr. Pynchon, and continued in the Colony only so long as Mr. Pynchon did. ${ }^{2}$ A house was built for hin by a voluntary assessment in 1639; and he received a salary of forty pounds a year, of which, in 1638 , Mr. Pynchon paid $£ 246 s .8 d^{3}$

All the settlements on the ConnecticutWethersfield, Hartford, Windsor, and Agawam were at first united under a joint commission, appointed by the General Court of Massachusetts, of which Mr. Pynchon was a member. He attended a court held at Hartford in November,

I Hist. of Conn. Valley, 33. a Hist. of Conn. Valley, 33 .

2 Holland's History, vol. i. 3 I. 
$163_{3} 6$, and also in 1637 . In 1638 , Rev. George Moxon and John Burr were chosen to represent Agawam at the same court. ${ }^{1}$ It had been uncertain how many of the settlements were under the jurisdiction of Massachusetts; but, in 1638 , the people of Agawam became satisfied that "by God's Providence they were now fallen into the line of the Massachusetts jurisdiction;" and they chose Mr. William Pynchon "to execute the office of a magistrate in this our plantation of Agawam," "till we receive further directions from the General Court in the Massachusetts Bay." The record of this action occupies the second page in the manuscript volume known as "The Pynchon Record Book." The magistrate was authorized "to administer oaths, issue warrants, hear and examine misdemeanors, inflict corporal punishment by whipping and the stocks, to commit to prison; to try actions for debt or trespass, and keep records of verdicts, judgments, and executions, and whatever else may tend to the king's peace." 2 It was agreed, on account of the scarcity of men, that six persons should be deemed a "good and sufficient jury to try any action, under the sum of ten pounds."

1 Holland's History, vol. i. 33 .

2 Ibid. 


\section{IV.}

THis was really a form of government, adopted by the inhabitants of the Colony, and was an assumption of the right of self-govern- a New ment, and especially of independence of Government. the authority of Connecticut. This action led to a prolonged controversy, in which Mr. Pynchon acted as the leader of the Colonists. Their position was finally sustained by the General Court of Massachusetts, which, on the $2 \mathrm{~d}$ of June, I64 I, adopted an elaborate paper, ${ }^{1}$ which asserted the claim of the Massachusetts Colony to the plantation, and ordered that "William Pynchon, gent, for the year shall have full power and authority to govern the inhabitants of Agawam, now Springfield, to hear and determine all causes and offences, both civil and criminal, that reach not to life, limbs, or banishment, according to the laws heare established." A little earlier than this, namely, the I 4 th of April, I640, the inhabitants assembled in general town-meeting, and changed the name of their plantation from Agawam to Springfield, as a compliment to Mr. Pynchon, whose home was in Springfield before his remoral to New. England. ${ }^{2}$ Mr. Pynchon was the magistrate of the Colony from the beginning to 165 I, first as a

1 Mass. Records, vol. i. 32r. ${ }^{2}$ Holland's History, vol. i. 34. 
member of the joint commission, then by vote of the people of Agawam, and after June 2, I64I, by commission from the General Court.

The records of his court show the variety and importance of his duties. One of the most important cases was a suit for slander. John Woodcock was complained of for slandering the pastor, Rev. George Moxon, by saying that the said Moxon had taken a false oath against him at Hartford. Mr. Moxon claimed $\& 9$ i 9 s. damages, but the jury awarded him $£ 6$ I $3 s$. There were suits for the collection of debts, and for violation of contract. Estates were settled in Mr. Pynchon's court, and the inventories in his Record Book give us glimpses of the sort of property and of household furniture in those times, as well as of the prices at which articles were valued. In $165 \mathrm{I}$, Hugh Parsons was apprehended on charge of witchcraft. The testimony against him is recorded by Mr. Pynchon. The duty of the magistrate consisted in the examination of witnesses. Parsons was sent to Boston for trial. Witnesses were produced, and the testimony taken in Springfield A case of was read, and the prisoner was found Witchcraft. guilty of the sin of witchcraft. The General Court reviewed the case and reversed the verdict. The wife of Parsons had been insane, and had taken the life of her infant child. She was arrested for the double crime of witchcraft 
and murder. Her examination was before Mr. Pynchon. She was tried in Boston, and found guilty of murder only. As there is no further record in her case, it is probable that she died in prison. This was forty years earlier than the great excitement in connection with witchcraft in Salem and Boston. It was, so far as I know, the earliest trial for witchcraft in Massachusetts.

The settlers very early adopted a code of municipal regulations. The annual town-meeting was fixed upon the first Tuesday in November. ${ }^{1}$ Every householder was required to have a ladder annexed to his house, as a security in case of fire, and to have his chimney swept at stated periods. It was forbidden to carry fire from house to house, not being sufficiently covered, on penalty of a fine of 5 s., and a liability for all damages. As the houses were covered with thatch, and the chimneys were wooden frames covered with mortar, and there was much inflammable material in the street, the need of this regulation is apparent. November 14, 1639, it was ordered that the "Sealed Peck, which Mr. Pynchon hath, shall be the ordinary Peck to buy and sell by in the Plantation." "The exercise of trayning was to be practiced one day in every month." No person was to trade, give, or lend to any Indian any quantity of powder, little or great, under penalty of $40 s$.

1 Address by George Bliss, IS2S, Appendix N. 
The wages of carpenters were fixed at $2 s .6 d$. a day, for the nine best months, and at $2 s$. from the

Laws in

Regard to roth of November to the roth of FebPrices.

ruary. Mowers should have 2s. $6 d$. a day. Sawers, 6s. $6 d$. per hundred feet, "they to fall and hewe, and the owner to bring to the pitt." Ordinary farm labor was $2 s$. a day for nine months, and $18 d$. for three months; only from the 24th of April to the 24th of June they "are left to their liberty as men can agree." A day's work was the whole day, allowing convenient time for food and rest. Violation of these rules to be punished "by the Magistrate according to the quality and nature of the offence." Any man elected to any office in the town, and refusing or neglecting to serve, "shall pay to the Town Treasurer 20s., unless he have served in that office the year before." And any inhabitant who should absent himself from town-meeting should be liable to a fine of $2 s .6 d$. " Jan. 8, 1646, it was agreed by the plantation with John Matthews to beat the drum for the meetings, for a year's space, at ro A.M. on Lecture days, and 9, on the Lord's days, in the fournoons only, and he is to beat it from Mr. Moxon's to R. Stebbins house, and ye meetings to begin within half an hour after, for which his paynes, he is to have $7 d$., in wampum, of every family in the town, or a peck of Indian corn if they have not wampum." 
Mr. Pynchon succeeded in preserving friendly relations with the Indians of the vicinity by a wise and conciliatory policy. ${ }^{1}$ One part of his policy was to treat the Indians as an independent people. In 1648, for

Relations with the Indians. example, he was directed by Lieutenant-Governor Dudley to take into custody certain Indians who had murdered some other Indians. In his answer Mr. Pynchon convinced Governor Dudley that neither the murderers nor those murdered were under the jurisdiction of the Colony. The attempt to interfere was at once abandoned by the authorities at Boston. But whenever the Indians committed offences against our own people, Mr. Pynchon claimed jurisdiction, and by a wise blending of authority, with an appeal to the Indian's sense of justice, he commonly succeeded in securing redress. The Indians had confidence in him, and were plainly ready to be guided by his wishes.

Besides his public duties, Mr. Pynchon was an active business man. The trade in beaver and other furs was very lucrative, and this trade in the vicinity of Springfield was controlled by him. To facilitate this trade, he early established a warehouse near the southern limit of what was then considered Springfield. This place still retains the name of Warehouse Point, and is a station

1 Address by Judge Morris, 1876 . 
on the railroad below Springfield. It was for many years the centre of an extensive trade with the Indians, and was the point from which the furs were shipped to England. Mr. Pynchon added very largely to his fortune while in Springfield, and at the time of his return to England was one of the richest men in New England.

He was also the representative man of Springfield abroad. The communications of the government at Boston were made through him. For a few years after he went to Springfield he was naturally left off from the Board of Assistants. But, in 1643 , the Colony having become well established, and the Bay Path more easily passed over, Mr. Pynchon was again elected an Assistant, and was re-elected annually until 1650.

\section{V.}

THis brings us to the time of the publication of Mr. Pynchon's famous book, entitled "The Meritorious Price of Our Redemption." It is a small quarto volume of a hundred and fifty-eight pages, " printed in London, by T. M. and George Whittington and James Moxon, and to be sold at the Blue Anchor in Cornhill, near the Royal Exchange, 1650." It is now exceedingly rare. There is one copy in the Congregational Library, 
Boston, one in the British Museum, and only one other, so far as I can learn, - that an elegantly bound copy that has been recently purchased by Rev. Thomas R. Pynchon, D.D., of Hartford, Connecticut. Some years ago this copy brought four hundred dollars, a larger sum than the whole edition cost in the beginning.

This book was received in Boston in the summer of 1650 , and produced a great exciteMr. Pynchon's ment. The General Court, ${ }^{1}$ coming Famous Book. together in October, adopted a solemn protest against the many errors and heresies of the book. This protest was made, they say, "for vindication of the truth," and also "to keep the people here committed to our care in the true knowledge and faith of our Lord Jesus Christ;" "and likewise, for the clearing of ourselves to our Christian brethren and others in England," "where this book was printed and is dispersed." They protest their innocency, as not "privy to the writinge, composinge, printinge, nor divulginge thereof," and declare that they "detest and abhorre many of the opinions and assertions therein, as false, erronyous, and hereticale;" and for proof of their sincerity in this protest they "condemne the said booke to be burned in the market place, at Boston, by the common executioner." They also summon Mr. Pynchon to

1 Mass. Records, vol, iii. 215. 
appear before the next General Court to answer whether "he will owne the booke as his or not, which, if he doth, we purpose (God willinge) to proceed with him according to his demerits, unless he retract the same." It was also ordered that Mr. John Norton, of Ipswich, "should be entreated to answer Mr. Pynchon's book with all convenient speed." It was also ordered, and this casts light upon the motive for these rapid and extreme measures, - that the foregoing declaration "be signed by the Secretary, and sent to England to be printed there." No one can tell, at this distance of time, all the reasons for this unusual action by the General Court. It is plain that it was not simply a judicial proceeding. There were politics in the case. The state of parties; the opinions of men who happened to be, just at that time, at the head of affairs; the fears of those who were most solicitous to maintain a certain type of theological opinion; the presence in the Colony of men whose views were more liberal, and the desire to hold them in check, all these entered into the motives of those who controlled the action of the General Court.

Mr. Pynchon was an honored magistrate, a member for many years of the General Court, a gentleman now past his sixtieth year, whose opinions had been treated with great respect throughout the history of the Colony, and who was 
certainly entitled to be treated with great consideration. But the defection of such a man from the truth, as it was held by men like Endicott and Dudley, would be a very serious matter, and one that must be corrected if possible. There was a law of Massachusetts, passed four years before, which condemned to fine and banishment whosoever should "go about to subvert and destroy the Christian faith and religion by broaching and maintaining" certain "damnable heresies," among which was specified that of "denying that Christ gave himself a ransom for our sins." 1 This, the book was understood to do. Mr. Palfrey also suggests that there was an unusual solicitude in the Colony as to the course of affairs in England, after the execution of King Charles, and also that the moderating influence of Governor Winthrop was removed just at this time. We know that Thomas Dudley was Governor, ${ }^{3}$ and John Endicott Deputy Governor, both of whom were men disposed to favor extreme measures for the maintenance of their standard of orthodoxy. A letter written by John Cotton to certain brethren in England, at the time, shows that the action was hastened by the fact that "a

1 This is the statement of Mr. Palfrey. He cites Mass. Records, vol. ii. I77; Code of 1658,34 .

2 Palfrey's History, vol. ii. 395, note.

3 Mass. Records, vol. iii. I $\$ 2$. 
ship was in the harbor, ready to sail for England." "Now the court," 1 he says, "perceiving by the title-page, that the contents of the book were unsound and derogatory both to the justice of God and the grace of Christ, which would do great harm, they judged it meet, whilst the ship stayed, to declare their own judgement against the book, and to send a copy of their declaration to England by that ship."

\section{VI.}

THE book itself is worthy of more than a passing notice as a part of the history of the times. It is the production of a very intelligent layman, living upon the outermost rim of civilization, and moved by the currents of theological opinion in character his time to put forth his independent of the Book. protest against opinions that seemed to him inconsistent with the Word of God. Those were the days of the Westminster Assembly, which sat from 1643 to I647. The Assembly had carried the expression of Calvinistic doctrine further than moderate Puritans like Mr. Pynchon would be ready to go. For Mr. Pynchon, like many of those who came with Governor Winthrop, had been a devout member of the Church of England. He was one of the wardens in the

1 Appendix to John Norton's Answer to Pynchon. 
church in Springfield, in Old England. ${ }^{1}$ His theological opinions had been formed under the preaching of the ministers of the Established Church, rather than under the Calvinistic preachers of New England. He was properly a NonConformist, but not a Separatist.

The assembly" declares that Christ "bore the weight of God's wrath ;" "laid down his life an offering for sin;" "satisfied divine justice ;" was " under the infinite wrath of God;" that He "did fully discharge the debt of" the elect, "and did make a proper, real, and full satisfaction to his Father's justice in their behalf;" that we are justified by the "imputing the obedience and satisfaction of Christ" unto us; that God "imputes the righteousness of Christ "unto us. ${ }^{3}$ The ministers of New England were accustomed to use language which went further than these guarded statements of the Assembly. John Norton, in his reply to Pynchon, maintains, in an elaborate argument, that the sins of the elect were imputed to our Saviour; that for their sins He suffered the torments of hell, and that the righteousness of Christ is imputed to the elect.

The heresies which the General Court found

1 These facts are given on the authority of Professor Pynchon, of Hartford, who states that there is a tablet in the church in Springfield which shows the fact.

2 Larger Catechism, ii. 49. Ibid., ii. 38.

${ }^{8}$ Confession, xi. s. II, ch. xi. I. Larger Catechism, 27 I. 
upon the title-page of Mr. Pynchon's book were these: That Christ did not suffer for us those unutterable torments of God's wrath which commonly are called hell torments; and that $\mathrm{He}$ did not bear our sins by imputation, and consequently did not bear the curse of the Law for them; and also that the righteousness of Christ is not imputed to us. The most vigorous part of the book is the discussion of the texts of Scripture which are supposed to prove that our sins were imputed to Christ, and that He suffered the wrath of God, and the punishment due for the sins of the elect. The discussion of Isa. liii. 4-6; 2 Cor. v. 2 I ; Ps. xxii. I ; Matt. xxvi. 37 ; Luke xxii. 43-44; and Heb. v. 7 , is very close and logical. I have followed his reasonings with great interest. $\mathrm{He}$ shows an acquaintance with the Hebrew and Greek texts, refers to the Septuagint version, compares the rendering of various passages in the Genevan version with that in Tyndale, and in King James's version. He was a correspondent of Ainsworth, and quotes in support of his opinions an autograph letter from that theologian. He scholarship of quotes Ainsworth, Broughton, Robert Mr. Pynchon. Wilmot, John Calvin, Martin Luther, Nichols, Richardson, Ursinus, Bastingius, Goodwin, Palanus, John Forbes, and St. Augustine, thirteen in all of the great theologians.

Following this polemic part of the book is the 
constructive part, in which he attempts to define the real basis of our redemption. In this he starts from the passage in Rom. v. I9, which reads: "For as by one man's disobedience many were made sinners, so by the obedience of one shall many be made righteous." He holds that as Adam's disobedience ruined the world, so Christ's perfect obedience, as our Mediator, redeemed the world. Christ had His work set before Him by the Father. This was the work which He had completed, when He said, "I have finished the work which Thou gavest me to do." ${ }^{1}$ If His obedience had been in the slightest degree imperfect, it would have vitiated the entire work. His death was the final test of His obedience. If $\mathrm{He}$ had died unwillingly $\mathrm{He}$ had died in vain. So the death of Christ was a voluntary death. "I lay down my life that I might take it again. No man taketh it from me, but I lay it down of myself. I have power to lay it down, and I have power to take it again." ${ }^{2}$ Mr. Pynchon says: "His divine nature was the altar upon which He sacrificed His human nature." His humanity was the oblation. "Then," he goes on to say, "His mediatorial death may well be the Death of called a miraculous death. It was no christ less mirculous than the raising the voluntary. less miraculous than the raising the dead body of Lazarus." The Devil and his agents had power to bruise $\mathrm{Him}$, and buffet $\mathrm{Him}$, and to

1 John xvii. 4.

2 John x. I7-IS. 
nail Him to the cross. But they had no power to separate His soul from His body. So His death was not passive. It was active, and so a part of $\mathrm{His}$ mediatorial obedience. He quotes Augustine, who says, "Who can sleep when he wist, as Christ died when He would? Who can lay aside his garment, as Christ laid aside His flesh? Who can leave his place so as Christ left His life?" 1 Christ died before the thieves, so that "Pilate marvelled if $\mathrm{He}$ were already dead." 2 He died when the life of obedience set for Him was finished, "whereof His mediatorial death was the master-piece." $\mathrm{He}$ said that it was "finished," and then, "He bowed His head and gave up the ghost." ${ }^{3}$ So Christ did not suffer the wrath of God, but He did the will of God. We may be saved because the law, which was broken by disobedience, was honored and restored by the obedience of the God-man.

\section{VII.}

IT was ordered by the General Court, after they had burned Mr. Pynchon's book, "that Mr. Norton, Action of the one of the reverend elders of Ipswich, General court. should be intreated to answer Mr. Pynchon's booke with all convenient speed." 4 This John Norton was a man of great reputation
1 Tractate upon John, II9.
2 Mark xv. 44.

8 John xix. 30.

4 Mass. Records, vol. iii. 216. 
in his day. He was a student at Cambridge University, and was master of an elegant Latin style. He succeeded John Cotton as pastor of the First Church in Boston. ${ }^{1}$ His widow, Madame Norton, gave the Old South the ground on which the Old South meeting-house on Washington Street now stands. ${ }^{2}$ Mr. Norton's reply is entitled, "A Discussion of that Great Point in Divinity, the Sufferings of Christ." It is a very able and learned work, thoroughly scientific in its methods, and sets forth the doctrine of the Westminster Assembly concerning the Atonement, and goes beyond that Confession in respect to Imputation. ${ }^{3}$ For this work Mr. Norton received from the General Court the sum of $£ 20$, with a vote of thanks; and they sent his book to England to be printed.

In addition to providing for a reply to Mr. Pynchon's book, the General Court advised him to confer with Mr. John Cotton, Mr. Norrice, and Mr. Norton about some points in his book. ${ }^{4}$ His conference with them naturally broadened his view of the subject he had in hand. ${ }^{5}$ He had been but a solitary thinker, and in giving emphasis to his protest against the extreme satisfaction theory, he

1 Memorial History of Boston, vol. i. 464. Sprague's Annals, Congl., vol. i. 58. See this volume, i23.

2 Memorial History of Boston, vol. i. I94.

3 Palfrey, vol. ii. 396, note.

4 Mass. Records, vol. iii. 239, also, 248.

5 Mass. Records, vol. iii. 229. 
had failed to do justice to the relation of the work of the Redeemer to sin and guilt. This, as a conscientious man, he was more than willing to acknowledge. Accordingly he appeared before the General Court, in May, 165I, with the following paper :-

"According to the Court's advice, I have Conferred with Mr. Cotton, Mr. Norrice, and Mr. Norton statement of about some points of the greatest conseMr. Pynchon quence in my book, and I hope I have so to the court. explayned my meaninge to them as to take off the worst construction; and it hath pleased God to let me see that I have not spoken in my book so fully of the price, and merit of Christ sufferings as I should have done, for in my booke I call them but trialls of his obedience, yet intending thereby to amplyfy and exalt the mediatorial obedyence of Christ as the only meritorious price of man's redemption : but now, at present, I am much inclined to think that his sufferings were appointed by God for a further end, namely, as the due punishment of our sins by way of satisfaction to divine justice for man's redemption.

"Your humble servant, in all dutifull respects, "William Princhon." 1

\section{VIII.}

THIS is spoken of by several authorities as a retraction; and Dr. Holland ${ }^{2}$ intimates that he

1 Mass. Records, vol. iii. 229.

${ }^{2}$ Holland's History, vol. i. 3 S. Art. on Pynchon in N. E. Hist. and Gen. Register, Oct. 1859 . 
"was convinced against his will." But there is no retraction here; but only a frank statement by a sincere and ingenuous man that after conference with his friends, the learned divines, he had become satisfied that in one respect he had failed to do justice to one side of an important truth; and further, that he found that some of his expressions had been misunderstood. Certainly, Mr. Pynchon was not the man to be "convinced against his will," or to retract any statement which he believed to be true. Besides, as we shall see, Mr. Pynchon was really master of the situation, and his opponents had more occasion to fear him than he had to fear them. That his paper was not taken as a retraction is evident also from the action of the Court, which voted that this paper showed Mr. Pynchon to be in a hopeful way, and dismissed him till the October session to study the questions by the aid of Mr. Norton's reply, directing that he should appear in October and give all due satisfaction.

At this session of the General Court Mr. Pynchon was not re-elected one of the Assistants, and was left out of the magistracy. In October, he failed to appear, and the General Court ${ }^{1}$ judged it "meete that all patience be exercised towards him, that he may be reduced into the way of truth, and renounce his errors and heresies," and there-

1 Mass. Records, vol. iii. 257. 
fore, as nothing else was possible, gave him until the next General Court in May, "that he may give full satisfaction for his offence, which they more desire than to proceed to so great a censure as his offence deserves." So he was placed under bonds of $£$ roo to appear in May "to stand to the judgement and censure of the Courte."

This is the last reference to this case in the Records of Massachusetts. Mr. Pynchon did not appear at the next session of the Court. Whether his bail of $\delta$ Ioo was forfeited we have no means of knowing. During that year, he returned to England. Of course he went openly, and probably sailed from Boston. A part of his family followed him; but his son John remained in Springfield, and became the most important man in the Colony, succeeding to his father's influence and authority. Thus it appears that, notwithstanding the vigorous terms employed by the General Court in October, I650, proposing, "(God willing) to proceed with" Mr. Pynchon "according to his demerits, unless he retracts his heresies," he yet remained within their jurisdiction for about two years, and in that time appeared before them only once, although summoned three times, and in the end chose his own time for leaving the Colony, and retiring, with his princely fortune, to his estate in England.

It deserves to be mentioned, as a part of the 
history of the times, that Sir Henry Vane wrote to the Magistrates, complaining of the course they had taken, and was answered in a joint Ietters from letter by nine of them. ${ }^{1} \quad$ A letter was England. also written by certain men of influence in England to the ministers of Boston, and others, urging them to set a favorable construction upon the tenets set forth in Mr. Pynchon's book "as disputable, and to some of note probable;" and requesting the ministers to "intercede with the Magistrates to deal favorably with him, as a gentleman pious, and deserving." 2 To this letter a reply was made, signed by John Cotton, Richard Mather, and three others, which explained the occasion of the promptness of the Court in its first action, and stated that the Court was disposed to deal favorably with the author of the book, appointing three, all friends and acquaintances, such as himself chose, to confer with him, and finding him yielding in some main point, which he willingly expressed under his own hand, the Court readily accepted the same. ${ }^{3}$

1 Palfrey's New England, vol. ii. 396.

2 Appendix to Norton's Answer to Pynchon.

8 The following is on the first page of John Eliot's record of church members, Roxbury, Mass. :-

"Mr William Pinchon: he was chosen an Assistant, yearely so long as he lived among us : his wife dyed soone after he landed at N. Eng: he brought 4 children to N. E. Ann, Mary, John, Margret. After some years he married $M^{\text {ris }}$ Francis Samford, a grave matron 


\section{IX.}

ON arriving in England, Mr. Pynchon settled in Wraysbury, on the Thames, in Buckinghammis Life in shire. This place is in the very heart England. of England, about three miles below Windsor Castle, and directly opposite Magna Charta Island and Runnymede. Horton, where Milton at one time lived, is an adjoining town. He found himself under the Puritan Commonwealth, in England, which must have been agreeable to one of his political and religious opinions. In the enjoyment of an ample fortune, surrounded by many friends of his earlier life, with abundant leisure, Mr. Pynchon appears to have given the

of the church at Dorchester. When so many removed frō these parts to Plant Conecicot riv ${ }^{r}$ he also wth othr company went thithr $\&$ planted at a place called Agawam, \& was recomended to the church at windsor on Conecticott, vntill such time as it should please God to $\bar{p}$ vide $y^{t}$ they might enter into church estate among themselves. his daughter Ann: was married to Mr Smith, sone to

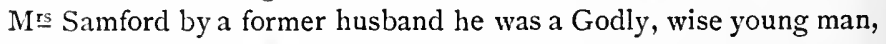
$\&$ removed to Agawam w $w^{\text {th }}$ his parents. His daughter mary was married to Mr Hollioke, the sone of Mr Hollioke of Linn; Mr Pinchons ancient freind.

"Afterwards he wrote a Dialogue concerning Justification, wh was printed anno 1650 , stiled the meritorious price, a book full of error $\&$ weakens, $\&$ some heresies $w^{\text {ch }}$ the Generall Court of ye Massachusetts Condemned to be burnt, \& appointed Mr John Norton then Teacher at Ipswich to confute ye errors contained therein." 
ten remaining years of his life to study and writing. The man who had helped in gathering two Congregational churches in New England, returned to the Church of England, and was buried in the ancient churchyard, under the shadow of one of the most beautiful of the rural churches of Old England. ${ }^{1}$

The year of his arrival in England he published:

"The Jews' Synagogue, a Treatise concerning the Worship used by the Jews. Quarto. London, 1652. John Bellamie."

Two years later, he published two treatises on the Sabbath:-

"The Time when the First Sabbath was ordained. By William Pynchon, Esq. Published by authority. London: Printed by R. G., and to be sold by T. N. at the Three Lions in Cornhill, near the Royal Exchange. I654."

"Holy Time: or The True Limits of the Lord's Day. By William Pynchon, Esq. Published by authority. Printed at London, by R. G., and are

1 In I886, I visited Wraysbury. The railroad station is a small and very modest one, not far from the Thames, and about twenty miles from London. The scenery has been compared to that of the Connecticut valley. There is perhaps a suggestion of that valley, and of the hills on the west, but the Thames at that point is much smaller than the Connecticut. In that quiet retreat, environed by the scenes most memorable in the history of English liberty, this great Puritan found the repose which was denied him in Massachusetts. 
to be sold by T.N., at the sign of the Three Lions, in Cornhill, near the Royal Exchange. I654."

Mr. Norton's answer to Mr. Pynchon's first book was not published till I $_{53}$. Two years later, Mr. Pynchon published a rejoinder, of which the following is the title:-

"The Meritorious Price of Man's Redemption; or Christ's Satisfaction Discussed and Explained. By William Pynchon, late of New England. 1655. Thomas Newbury, London, I655."

It is dedicated to Oliver St. John, the author esteeming him " an able Judge, not only in those controversies that concern the common laws of the land, but also in divine controversies."

This is a quarto of four hundred and forty pages, and is by far the most elaborate of $\mathrm{Mr}$. Pynchon's works. In this he uses the "altar terms," as they have been called, and seems to recognize the side of truth to which he referred in his letter to the General Court; namely, that in some way "the sufferings of Christ" "were appointed " as "the due punishment of our sins, by way of satisfaction of divine justice." $\mathrm{He}$ controverts again, with great ability, the doctrine that our Lord suffered the vindictive wrath of God and the torments of hell.

A copy of this book is in the library of Harvard University.

His last book was entitled: "The Covenant of 
Nature made with Adam Described, etc., and Cleared from Sundry Great Mistakes." In this volume the address to the reader is dated: "From my Study, Wraysbury, Feb. 10, I66I."

Mr. Pynchon died at Wraysbury some time in October, 1662, aged seventy-two years.

He was twice married. No record that I have seen gives the date of the first marriage, or the name of his wife. She came with him to New England, and died in Roxbury during the first year, perhaps in consequence of the hardships of the life in the new country. The children of this marriage were:-

John, born 1621 ;

Annie, who married Henry Smith;

Margaret, who married William Davis, of Boston ;

Mary, who married Elizur Holyoke;

And a son, who was drowned in the Connecticut River. ${ }^{1}$

After the death of his wife, Mr. Pynchon married Mrs. Frances Samford, "a grave matron of the church at Dorchester," as the Roxbury church records say, but they do not give the date of the marriage. Mrs. Pynchon died at Wraysbury, October 10, 1657 .

1 " Mr. Pynchon lately lost a boy, who tending cows near our river, too venturously went into a birchen canowe, which overturned, and he was drowned." [Mr. Moxon's letter to Governor Winthrop about I638.] - Conn. Valley, vol. i. 40. 
There is a striking portrait of Mr. Pynchon in the possession of the Essex Historical Society of Salem. It was painted in England, and sent by him to his son John. The frontispiece of this volume is taken from that painting. With his long, closely-fitting coat and small-clothes, the broad collar or band of linen lying flat upon his shoulders, and a closely-fitting silk cap upon his head, he was the impersonation of quiet dignity, and patriarchal grace. His seal ring, with his arms, is still in existence, in the possession of a descendant at the South. 


\section{V.}

The Family and Social Life of the Puritans. 


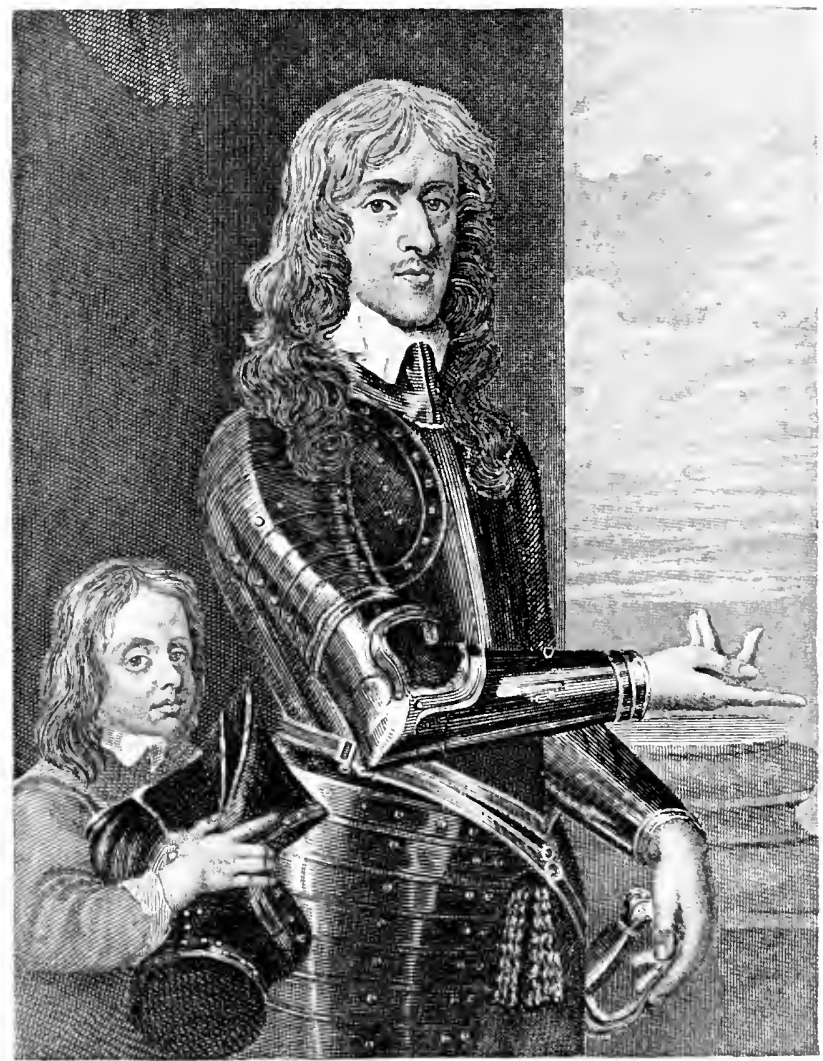

COLONLL JOIIN IIUTCIIINSON

OF OWTHORPE. 


\section{The Family and Social Life of the Puritans.}

"H OME, as we conceive it now," says Mr. John Richard Green, "was the creation of the Puritan." He gives the reason for his statement. "Wife and child rose from mere dependants on the will of husband or father, as husband and father saw in them saints like himself, souls hallowed by the touch of a divine Spirit, and called with a divine calling like his own. The sense of spiritual fellowship gave a new tenderness and refinement to the common family affections." ${ }^{1}$ The philosophic historian is undoubtedly correct. The Puritan had broken away from the old traditions, and from ecclesiastical bonds, and had come into a realm of comparatively free and liberal thought. His fellowship was with the Father, and with His Son, Jesus Christ, without the intervention of the priest or of the Church. So far forth he was a free man, in personal relations with God. All the members of his family were equally free, and equally the favorites of God. This intense indi-

1 Green's History of the English People, vol. iii. I9. 
vidualism opened a new social life, with a broader charity, and a warmer and more absorbing love. It developed a new type of citizenship, and has tended undoubtedly toward Democracy. It has lifted the common man to an equality with those in the privileged classes. The religious sentiment of the Puritans has developed the altruistic feeling, so abundant in modern life.

Some illustrations from Puritan history will make these statements plain, and will set forth the reasons for them. We need to know what sort of men and women the Puritans were in their homes.

\section{I.}

Mrs. Hutchinson, writing to her children concerning their father, has given a vivid description of that model Puritan, Colonel John Hutchinson, ${ }^{1}$ of Owthorpe, who lived in the time of Oliver Cromwell. She says :-

" He was of a middle stature, of a slender and exactly well-proportional shape in all parts, his hair of light col. Hutchinson, brown, very thick set in his youth, softer than a Typical the finest silk, and curling into loose great Puritan.

rings at the ends: his eyes of a lively gray, his visage thin, his mouth well made, and his lips very ruddy and graceful; his teeth even and white as the purest ivory, his forehead not very high, his nose raised and

1 See his portrait, page 220 . 
sharp; but withal he had a most amiable countenance, which carried in it something of magnanimity and majesty mixed with sweetness, that at the same time bespoke love and awe in all that saw him." "He was nimble and active and graceful in all his motions; he was apt for any bodily exercise; he could dance admirably well, but neither in youth nor riper years made any practice of it; he had skill in fencing, such as became a gentleman; he had a great love of music; . . . he had good judgment in paintings, graving, sculpture, and all liberal arts, and had many curiosities of all kinds; he took much pleasure in the improvement of grounds, in planting groves and walks, and fruit trees; he was wonderfully neat, cleanly and genteel in his habit." "He hated persecution for religion, and was always a champion for all religious people against all oppressors." "Neither in youth, nor riper age could the most fair or enticing women ever draw him into unnecessary familiarity or vain converse or dalliance with them, yet he despised nothing of the female sex but their follies and vanities; wise and virtuous women he loved, and delighted in all pure, holy and unblameable conversation with them." "For conjugal affection to his wife, it was such as whosoever would draw out a rule of honor, kindness and religion, need no more, but exactly draw out his example; never man had a greater passion for a woman, nor a more honorable esteem for a wife. He governed by persuasion, which he never employed but to things honorable and profitable for herself; he loved her soul and her honor more than her outside, and yet he had for her person a constant indulgence." "So constant was he in his love that when she ceased to be young and lovely, he began to show most fondness; he loved her at such a kind and 
generous rate as words cannot express." "He was as kind a father, as dear a brother, as good a master, and as faithful a friend as the world had."

"He understood well, and as well performed when he undertook it, the military art in all parts of it; he naturally loved the employment as it suited with his active temper more than any, conceiving a mutual delight in leading those men that loved his conduct, and when he commanded soldiers, never was man more loved and reverenced by all that were under him," and "they joyed as much in his commands as he in their obedience." "He had a sweet and loving courtesy to the poorest, and would often employ many spare hours with the commonest soldiers and poorest laborers." 1

Yet this man, so gentle, so affectionate, so highly cultured, was a Puritan soldier - a Colonel in the army of Cromwell - who fought vigorously through the civil war. He was one of the judges who condemned the king to death. After Oliver Cromwell became Lord Protector, Colonel Hutchinson disclosed to him a plot against his life; and when Cromwell called him "My dear Colonel," and invited him to "come in and take a part" in his government, Hutchinson refused, telling him plainly that he liked not any of his ways since he broke up the Parliament. After the restoration of Charles the Second, Colonel Hutchinson suffered a long and cruel imprisonment, and finally died in prison, because he would not in any way com1 Memoirs of Colonel Hutchinson, Bohn's Edition, IS63, 19-35. 
promise his principles, or betray his friends. This man was one of the Ironsides, and yet his family and social life was as full of sweetness, and tenderness, - of the love of all beautiful and gracious things, - as the lives of those who are the choicest spirits of our own time.

Nor did Hutchinson stand alone among the Puritans of his time. John Milton is the completest type of Puritanism. "His youth shows us," says a recent writer, "how much of the gayety, the poetic ease, the intellectual culture of the Renaissance lingered in a Puritan home." His tract on Education is one of the broadest and most liberal treatises of the seventeenth century, - a prophecy of the nineteenth. Ithe Poet of the "Whenever the element of beauty is found in Milton," says Professor Shedd, "it is found in absolute purity." "A more absolute beauty and a more delicate aerial grace are not to be found than appear in the Comus, and the fourth book of Paradise Lost." 1

We read in the records of that age, of a certain Puritan mother, in humble life in England, that "she was very loving and obedient to her parents, loving and true to her husband, very tender-hearted to her children, loving all that were Godly." These illustrations of the Puritan spirit and temper can be multiplied from the records of that age.

1 Literary Essays, 23. 


\section{II.}

OnE of the reliable sources of information in respect to family and social life is the correspondence between members of families. Such letters are apt to be destroyed, especially the most significant and domestic letters. We have, fortunately, a large number of the letters which passed between Governor John Winthrop and his wife, and also his letters to his son. Winthrop was in many ways the best representative of the carly New England Puritans. There is a statue,

John Winthrop, in one of the public squares of Boston, the Founder of to John Winthrop, "Founder of MassaMassachusetts. chusetts," with the Bible in one hand, and the charter of the Colony in the other. Another statue of him is in the chapel of the cemetery at Mount Auburn. Another statue of him, as a representative of the State, stands in the Capitol at Washington. He was for eleven years the Governor of the Colony, and as long as he lived, he was its foremost citizen. From his letters and his journals, we derive our most definite knowledge of the life in the Colony in the first generation. He was born in England, in I $_{5} 88$, so that he was forty-two when he came to New England. Margaret Tyndal was his third wife. When Adam Winthrop, the aged father of John 
Winthrop, learned that she was betrothed to his son, he sent her a present, with a letter in which he addressed her as "Gentle Mistress Margaret," and assured her of his fatherly love and affection, spelling Love with a capital letter, and told her with the frankness of a patriarch, that he thought himself happy that in his old age "I shal injoye the familiar company of so virtuous and loving a daughter and passe the residue of my daise in peace and quietness." "I doe heare faithfully promise for my sonne that he will alwaise be a most kinde and lovinge husbande unto you."

Our first letter from John Winthrop is addressed to "My dearest friend and most heartily beloved Mrs. Margt Tyndall." This was before their marriage. The next is addressed to "My onely beloved spouse, my most sweet friend, and faithful companion of my pilgrim- Iohn Winthrop age, the happye, and hopefull supplye to his Wife.

(next Christ Jesus) of my greatest losses." $\mathrm{He}$ says at the end, "My father and mother salute thee heartily."

The next is addressed to "My deare wife," and was written when she was away from home attending at her mother's bedside in her last sickness. Later, he writes to her as "My Truely Beloved and Deare wife;" "My sweet wife;" "My most Deare and Sweet Spouse;" "My Good Wife;" "My Deare Wife, my Chiefe Love in this World;" 
and he subscribes the letters, "Thyne;" "Thy faithful husband;" "Thine as his owne;" "Thy faithful husband, still present with thee in his most unkind absence;" "So I kiss my sweet wife, and rest, Thy frail but faithful husband."

She begins her letter, "My Dear Husband;" and ends it with, "Your loving and obedient wife;" "Nost Deare and Lovinge Husband," and "Your obedient wife allways;" "My most Kinde and Loving Husband," "Your lovinge and obedient wife." In one letter she goes quite beyond all modern precedents, and writes, " Thy unworthy wife."

Here is a letter, written at Groton, in Suffolk, in 1630 , (N. s.) addressed to John Winthrop, Esq at Mr. Downing's house, in Fleet Street, and written just before his departure for New England.

"My Deare Husband, - I knowe thou art desyrus to heere often from us, $w^{\text {ch }}$ makes me take plesure in rightinge to thee, and in relatinge my true affections to thee and desyers of your wished welfayer. . . . I must part with my most deare Husban, wh is a very hard tryall for me to undergoe. If the Lord doe not supporte and healpe me in it, I shalbe unable to beare it. I have now received thy kinde letter $\mathrm{w}^{\text {ch }}$ I cannot reade without sheding a great many tears, but I will resine thee, and Margaret Win- give thee into the hands of the almiti God, throp's Letters who is allsoficient for thee, whome I truste to her Husband. will keep thee, and prosper thee in the way thou art to goe. . . . I know I shall have thy prayers to God for me that what is wanting in thy presence may be 
supplyed by the comfort of God's spirit. I am now full of passion, havinge newly received thy letter, and not able to right much. My sonne F. will right about other busines. I beginne to fear I shall see thee no more before thou goest (to New England) w $w^{\text {ch }}$ I should be very sory for and earnestly intreat thee that thou wilt com once more downe if it be possible."

The Governor did "com once more downe," after such a letter as that. He wrote:

"I purpose (if God will) to be with thee upon Thursdaye come señight, and then I must take my Farewell of thee, for a Sumers daye, and a winters daye. The Lord o̊ good God will, (I hope) sende us a happye meetinge againe in his good tyme: Amen." "Among other things let the brassen quart in the Larder house be putt up : \& my gray cloake and the coate $w^{\text {ch }}$ was my brother Fones: \& let this warrant inclosed to sent to Colchester to Mr Sam" Borrowes by the next tyme the carte goes. The Lord blesse thee my sweet wife, $w^{\text {th }}$ all our children."

Thy faithfull husband,

Feb : 5 1629. (O. S.)

Jo: WiNTHROP.

" Remember to putt me up some Cardons \& Card" ns seed." "The readinge of (thy letter) has dissolved my head into tears. . . . If I live, I will see thee ere I goe, I shall parte from thee with sorrowe enough: be comfortable my most sweet wife."

She wrote again: "I am glad to heere you will come home this weike, for I desire to enjoy thy sweete presence as ofte as I can, before that longe 
partinge come $w^{\text {ch }}$ I desyre the Lord to fit us for." He writes, February I 4th, "Thou must be my valentine, $\mathrm{fr}$ none hath challenged me." March 2d, the Governor writes again, having in the meantime been home to Groton to say farewell, and returned to London to complete his arrangements for the voyage to New England. He tells her that their two sons, and most of the servants have already gone to South Hampton: and adds, "Ah my most kinde \& deare wife, how sweet is thy love to me. The Lorde blesse thee \& thine, w $w^{\text {th }}$ the blessinges from above. ... So I kisse \& embrace thee \& rest thyne ever." March Ioth, he wrote again, sending his love to his children by name, including "the little one unknown," and to each of the servants, and to his old neighbors. Four days later, he writes again from Southampton; on the $22 \mathrm{~d}$, there is another letter to his wife, written "aboard the Arabella ridinge at the Cowes." He writes once more, March 2Sth, still on board the ship, which had been detained by adverse winds. "Our boys," he says, "are well, and cheerful, and have no mind of home. They lie both with me, and sleep as soundly in a rug, (for we use no sheets here,) as ever they did at Groton: and so do I myself." "Mondays and Fridays, at five of the clock at night we shall meet in spirit till we meet in person." "Yet if all these hopes should fail, blessed be our God, 
that we are assured we shall meet one day, if not as husband and wife, yet in a better condition." Once more, before the fleet set out on its voyage, he wrote, April $3 \mathrm{~d}$, to acknowledge two letters from his wife, and to tell her that "on friday when 5 of the clocke came," he "had respitt from his cares" to remember her, and to "parlye "with, and meet her "in Spiritt before the Lord."

These extracts from this correspondence two hundred and sixty years old - may give some impression of its quality. Time blots out almost all things written by the hand of man; but there are almost a hundred of these letters, which have been rescued from oblivion, and they give us, almost at first hand, repeated glimpses of the actual life of this representative Puritan family. The correspondence which passed between Governor Winthrop and his son John, cannot be quoted here, for lack of space, but it is, in its own way, as suggestive of the tenderness, and singular wisdom, and piety of this old family, as the correspondence from which these scattered specimen leaves have been selected. ${ }^{1}$

1 Twenty-seven of these letters were printed in I\$25, in the appendix to the first volume of Governor Winthrop's Journal. The others were printed in The Life and Letters of John Winthrop, by Hon. Robert C. Winthrop, Boston, I 869, and also in the Collections of the Massachusetts Historical Society. Rev. Joseph H. Twichell, of Hartford, Conn., edited an edition of fifty-eight of the letters, with the title, "Some Old Puritan Love Letters," New York, i 893. In this edition the old spelling is very carefully restored. 
It was the I6th of July before Governor Winthrop had an opportunity to send his next letter. The mails did not cross the Atlantic as frequently then as now. They had a long and tempestuous voyage, and his letter is full of gratitude for their preservation, as well as of affection for those left in the old home at Groton.

It was the $3 \mathrm{~d}$ of November (o. s.) of the next year when Mrs. Winthrop was able to join her husband. She went in the ship Lyon, with his eldest son, and other of his children. Great was the rejoicing at their arrival. "Divers of the Assistants, and most of the people of the near plantations came to welcome them, and brought, and sent, for divers days, great store of provisions, as fat hogs, kids, venison, poultry, geese, partridges, etc., so as the like joy, and manifestation of love had never been seen in New England. It was a great marvel," said Governor Winthrop, " that so much people, and such store of provisions could be gathered together at so few hours warning." 1

\section{III.}

IT is not difficult to conjecture what the social and family life would be in a community made up of such men and women as those seventeenth

1 The History of New England, from 1630 to 1649, by John Winthrop, Esq., Boston, 1853 . 
century Puritans of whom we have been reading. Such gentleness, and affection, and refinement of feeling, and such piety would bear fruit in the most beautiful lives.

But the records that have come down to us from the Colonial period of New England history give us a distinct picture of life as it actually went on from year to year. It Records of the actually went on from year to year. It colonial is marvellous how abundant these Period.

records are. Those old Pilgrims had a respect for their mission, and they were sure that those who should come after them would desire to know their history. We have, first of all, the incomparable histories written by Governor Bradford of Plymouth, and by Governor Winthrop of Boston. They cover the time from the earliest settlements to i646. We have also the official records, not only of these two oldest colonies, but of Rhode Island, Connecticut, and New Hampshire. These are supplemented by a great number of histories, and narratives, journals, pamphlets, and treatises, letters and replies, which make the life of that time luminous to those who will go to the original sources.

\section{IV.}

What then was the life in the Colonial period of our history? In the first place, it was a life in the earlier part of the seventeenth century. The 
fathers of New England were very much in advance of their time, and yet they were influLife in the enced by the spirit of their times. It colonial Age. is not only unwise but unjust to test their opinions, and their social habits, by the standards of our time. No intelligent student of their history will ignore the fact that the world has made marvellous progress since $\mathrm{I} 620$. The belief in witchcraft was, I think, universal in Christendom in that age. The great jurists and philosoShers of England were confident that there were such creatures as witches. Sir Natthew Hale, and Sir Thomas Browne, and Ralph Cudworth, and Blackstone, and even John Wesley believed in witchcraft." "It is supposed," says Professor Fisher, "that prior to the witchcraft epidemic in Massachusetts, thirty thousand persons had been put to death in England on this charge, seventystats five thousanct in France, and a hundred thousand in Germany."

Cruel punishments were inflicted in the times of Queen Elizabeth. She sent Mary Queen of

The Times of Queen Elizabeth.
Scots to the block, just as Charles the Second sent Sir Henry Vane to the block. The spirit of our age does not tolerate slavery, but slavery was common then. Our societies for the Prevention of Cruelty to Animals; Cruelty to Children; the laws that

1 Professor Fisher's History of the Christian Church, 479-483. 
protect children and women from excessive labor; that prohibit cock-fighting, and prize-fighting, and, in some States, prohibit bull-fighting, - all these are the outgrowths of the last years of the nineteenth century. We do not look for such things in the times of Oliver Cromwell.

It is not easy for us to do justice to an age so different from our own. Life was more simple in those days, yet in many ways it was more picturesque, more courtly, more reverent. The respect that was paid to parents, and to the aged, and to those in official posi- Seventeenth tions, the reverence for the Bible, and Century. the Church, and the Lord's-day, the interest in Philosophy and Theology, and in religious services, - these were very unlike the tendencies of our time. It does not follow that the life of that time was inferior to the life of to-day. Thosepeople were evidently sincere in the expression of their opinions. Their manners and methods of life grew out of their experiences. - The habits of Queen Elizabeth were very different from those of Queen Victoria, yet it may be that Elizabeth's place in history is higher than Victoria will deserve. Our nineteenth century has no poets or dramatists to be compared with Milton and Shakespeare. Certainly, we have no reason to look down upon the men who lived in the times of John Hampden, and Eliot, and Pym, and Vane, 
and Milton, and Cromwell. Mr. Gladstone has recently said: "I do not think we are stronger, but weaker, than the men of the Middle Ages. The men of the sixteenth century were stronger in brain power than our men." 1

\section{V.}

WE should also remember that the fathers of New England were pioneers. Those who make Our Fathers lived in a New Country. the first settlements in a new country cannot live as they had lived in their old homes. Many of the criticisms upon the Puritans are very inconsiderate. They have been spoken of as hard and narrow, because they did not have days of public festivity and amusement.

But the settlers at Plymouth had to build houses to shelter their families, with their own hands, in the depth of winter. They had no Poverty of the domestic animals except dogs. They Early Pioneers. had no ploughs. They must break up the land, and prepare it for corn with hoes. "The first beginning of any cattle in the land," says Bradford, "was in March, I624, when three heifers and a bull were landed." 2 For three years and more the Colony had been without milk or butter or cheese except such as came from abroad.

1 Review of Reviews, April, IS92. Interview with W. T. Stead.

2 liradford, 158. 
All their journeys were on foot or in boats. There was often great scarcity of food. There were no preserved meats, no vegetables, and no bread stuffs to be had. Water was the only drink, except beer and liquors. There was a time when lobsters, clams, and mussels furnished the principal food of the people. After the return of Governor Winslow from England, they were able to allow four ounces of bread a day to each inhabitant, and this was given out each day. Two years after the settlement was begun, two ships arrived from England, bringing a large number of the wives and children of the earliest settlers, who had been left behind at Leyden. It was a joyful reunion, and yet the new-comers "found their old friends in a very low condition; many were ragged in aparell : \& some little better than half naked." "The best dish they could present their friends with was a lobster, or a piece of fish, without bread, or anything els but a cupp of pure spring water." 1 "The long continuance of this diate," says Governor Bradford, "and their labors abroad had somewhat abated Ye freshness of their former complexion." The fact is, the new-comers hardly recognized their own kindred, so changed were they by the lack of nutritious food, and by the severity of their labors. Governor Bradford compares their condition to that of Jacob and his

1 Bradford, 145. 
sons in Canaan, in the time of famine. For, he says, although "the famine was great, or heavie in the land; yet they had such great herds, and store of cattle of sundrie kinds, which, besides flesh, must needs produce other food, as milke, butter \& cheese, \&c., and yet it was counted a sore affliction; theirs hear must need be very great, therefore, who not only wanted the staffe of bread, but all these things, and had no Egipte to goe too. But God fedd them out of ye sea for ye most parte, so wonderful is his providence over his in all ages; for his mercy endureth for ever." 1

In addition to these troubles, the Colony was in debt to the company in England, which had provided the vessel that brought them over, and the supplies for the settlers. For many years they were obliged to send to England, whatever they had gained from their trade with the natives, towards the payment of their debts. Besides this, they had among them a number of persons who were not honest or industrious men. Some of those who were sent over by the company in England were so bad that they were obliged to send them back at large expense. All through the history of the Plymouth Colony they had to carry along with them a good many people who had no sympathy with the high moral standards of the Pilgrims.

1 Bradford's History, 146. 
They were also exposed to attacks from the savages about them. 'They treated the Indians with great kindness and consideration; Danger from but they were never free from the danger the Indians. of a hostile attack. Their village was protected by a line of palisades, with bastions; and the gates were locked at night and guarded. They built a fort, on the top of which they planted six cannon. In times of special danger, a watch was kept up at the fort day and night." As the years went by, their hardships were less, but their condition was still that of pioneers, in a new country, with the ocean between them and the old home.

\section{VI.}

The larger Colony at Massachusetts Bay was better provided for. The first ships that came over brought with the passengers, cows, The Massachuhorses, goats, and swine. ${ }^{2}$ They had setts coiony. also a supply of provisions. And yet, more than a quarter of those who came to Salem died during the first winter. Two hundred of Governor Winthrop's company died before the close of the autumn. There was great suffering from the lack of food, in the winter that followed. Shell-fish had to serve for meat, and ground-nuts and acorns

1 Bradford, I1 3 , I 26.

2 Governor Winthrop's History, vol, i. 34-4t. 
for bread. The rude cabins which the people were able to put up were a very poor protection against the cold of a New England winter, for people, many of whom had lived in great comfort in the old country. "Oh the hunger that many suffered," said one of the old writers, "and saw no hope to be supplied, only by clams, and muscles, and fish." 1 When the first ship arrived from England, with provisions for the Colony, Governor Winthrop was giving the last handfuls of meal in the barrel to a poor man.

These settlements were also subject to alarms from bands of hostile Indians who were prowling about. $^{2}$ A few years later, they had occasion to fortify the harbor of Boston, and arm and drill the men of the Colony, because they had reason to expect a hostile attack from the king's ships. The colonies in Rhode Island, and Connecticut, and New Hampshire had a similar record of privation connecticut, and suffering during the first years. In Rhode Island, the course of time the industry and thrift
and New Eampshire. of the people brought them such comforts and such prosperity as can be had in new settlements. But life in New England was very simple for many years. In $163_{2}$, Governor Winthrop records the removal of the wind-mill from Newtown to Boston, because at Newtown it would not grind but with a westerly wind. The whole

1 Wonder Working Providence, xxiv. $\quad 2$ Winthrcp, vol. i. 59. 
Colony seems to have been dependent upon a single wind-mill. ${ }^{1}$

The next year, a water-mill was set up in Dorchester, and another in Roxbury. The same year a "Mercate" (Market) was authorized to be kept on Thursday, in Boston, "it being lecture day." The long journeys which The Wind-mill Governor Winthrop made on the business of the Colony were on foot, or in boats, for many years. When he visited Plymouth, Governor Bradford, - " a very discreet and grave man," - with Mr. Brewster the Elder, and some others came forth and met them without the town, and conducted them to the house of the Governor, where they were very kindly entertained, and feasted each day at several houses. On Wednesday following, "the Governor and his company came out of Plimouth about five in the morning; the Governor of Plimouth, with the pastor and Elder, etc., accompanying them near half a mile, out of town, in the dark." ${ }^{2}$

In the second generation, as almost always happens in a new country, the people in the New England colonies were, as a class, of ruder manners, and of a lower grade of intelligence than those who had come from the Mother Country. There was some improvement in the third generation; but all through the first century of our

1 Winthrop, vol. i. 104, 138 . 
history, the people had the characteristics of pioneers. It is not reasonable for the critics of our time to expect from these pioneers, of two hun. dred and sixty years ago, the broad and liberal views, and the generous culture of their descendants of the seventh generation.

\section{VII.}

Mr. Longfellow's poem, entitled, "The Courtship of Miles Standish, "gives us a very correct The courtship picture of the social and family life of of Miles

Standish.

the Pilgrims. The poet was interested in the tradition on which the poem is founded from family reasons.

It is not claimed that this poem is in all respects accurate in its statements. It is a work of art; and the poet has grouped about the central story a number of incidents which occurred in a little different connection. John Alden was not quite the youngest of those who came in the Mayflower, though he was a young man of twentyone. Rose Standish was not the first of those who died at Plymouth. The milk-white steer, which, according to the poem, carried the bride on its back, to her new home, after the simple marriage ceremony, was doubtless still in Old England when the marriage occurred, two years after the Mayflower went back. But after all the 
liberty which we have to allow tu the poet, it remains true that this poem gives a correct representation of the spirit of the Pilgrims, and of their way of life in 1623. The journals of Mr. Longfellow show that he was a diligent student of the early New England history at the time he was writing the poem. ${ }^{1}$ The characters in the rom are well-known persons in the history of the Colony. Miles Standish was such a man as the poet has described, even to the books The characters in his library, a catalogue of which has Authentic. been preserved. ${ }^{2}$ John Alden is a typical Pilgrim, with a warm heart, a high sense of honor, a vigilant conscience, and the imagination of an enthusiastic leader of men. He became a leading man in the Colony, was one of the Assistants more than forty years, treasurer of the Colony thirteen years, and was frequently a deputy to the General Court. Priscilla Mullins, - "the beautiful Puritan maiden," the lover of music, -

"Singing the hundredth Psalm, the grand old Puritan anthem,""While with her foot on the treadle she guided the wheel in its motion."

"Open wide on her lap, lay the well-worn psalm-book of Ainsworth,

Printed in Amsterdam, the words and the music together, Rough-hewn, angular notes, like stones in the wall of a churchyard."

1 Life of H. W. Longfellow, vol. ii. 259-320.

2 The Pilgrim Republic, 450-45r. 
Governor Bradfurd, also, is faithfully represented in the poem. 'So is Elder Brewster, though he wa not so aged a man, at the date of the mar. riage, as the poet would have him.

The tradition on which the action of the poem is fcunded, is certainly very old. It is probably authentic. It is very likely that the bashful captair . "A man not of words, but of actions," "A mas : $r$ of war, and not a maker of phrases" — was so indiscreet as to send his youthful secretary to ask for the hand of the young woman, who was

"... alone in the world; her father and mother and brother Died in the winter together."

Her reply, according to the best tradition, was, "Why so many words for the Captain, and no words for yourself, John?"

The charm of the poem for us is in its picture of the life at Plymouth. What can be finer than the description of the departure of the Mayflower? -

"Long in silence they watched the receding sail of the vessel, Much endeared to them all, as something living and human;

Then, as if filled with the spirit, and wrapt in a vision prophetic,

Baring his hoary head, the excellent Elder of Plymouth

Said, 'Let us pray!' and they prayed, and thanked the Lord and took courage.

Mournfully sobbed the waves at the base of the rock, and above them 
Bowed and whispered the wheat on the hill of death, and their kindred

Seemed to awake in their graves, and to join in the prayer that they uttered."

\section{Here is the new Pilgrim home:-}

"Meanwhile Alden at home had built him a new habitation, Solid, substantial, of timber rough-hewn from the firs of the forest.

Wooden-barred was the door, and the roof was covered with rushes;

Latticed the windows were, and the window-panes were of paper,

Oiled to admit the light, while wind and rain were excluded.

There too he dug a well, and around it planted an orchard:

Still may be seen to this day some trace of the well and the orchard."

"Oft when his labor was finished, with eager feet would the dreamer

Follow the pathway that ran through the woods to the house of Priscilla,

Led by illusions romantic and subtile deceptions of fancy,

Pleasure disguised as duty, and love in the semblance of friendship.

Ever of her he thought, when he fashioned the walls of his dwelling;

Ever of her he thought, when he delved in the soil of his garden ;

Ever of her he thought, when he read in his Bible on Sunday

Praise of the virtuous woman, as she is described in the Proverbs."

"This was the wedding morn of Priscilla the Puritan maiden. Friends were assembled together; the Elder and Magistrate also 
Graced the scene with their presence, and stood like the Law and the Gospel,

One with the sanction of earth and one with the blessing of Heaven.

Simple and brief was the wedding, as that of Ruth and of Boaz. Softly the youth and the maiden repeated the words of betrothal,

Taking each other for husband and wife in the Magistrate's presence,

After the Puritan way, and the laudable custom of Holland. Fervently then, and devoutly, the excellent Elder of Plymouth Prayed for the hearth and the home, that were founded that day in affection,

Speaking of life and of death, and imploring divine benedictions."

\section{When all was over we read:-}

"Onward the bridal procession now moved to their new habitation,

Happy husband and wife, and friends conversing together.

Pleasantly murmured the brook, as they crossed the ford in the forest,

Pleased with the image that passed, like a dream of love through its bosom,

Tremulous, floating in air, o'er the depths of the azure abysses."

"Like a picture it seemed of the primitive, pastoral ages,

Fresh with the youth of the world, and recalling Rebecca and Isaac,

Old and yet ever new, and simple and beautiful always, Love immortal and young in the endless succession of lovers. So through the Plymouth woods passed onward the bridal procession." 1

1 The Courtship of Miles Standish, 1859 . 


\section{VIII.}

THESE records and traditions may help us to understand the social and family life of the Puritans. We pass next to some of the practical methods by which these hardy pioneers directed their social and family life. We are not to expect them to follow the conventional rules of the Old World. They were men of ideas and of The Puritans independent principles. They had found in Advance of their Times. it impracticable to develop their ideas in England. The Stuarts, and those who belonged to their party, had crowded these vigorous Protestants the champions of civil and religious liberty from their homes, and they had come to the New World to develop their ideas in a free state and a free Church. They were men far in advance of their times. Longfellow has borrowed the strong expression of one of their leaders, when he says:

"God had sifted three kingdoms to find the wheat for this planting,

Then had sifted the wheat, as the living seed of a nation."

The Puritans sought to develop the individual. As they believed that each man was the special object of God's love and care, so they insisted that each child should be educated and trained for his duties in this life and beyond. That was the reason why they provided schools for the 
children of the people. They had no examples of such schools in England. They were more than two centuries in advance of the Mother Country in this respect. "Until quite recently," says an English writer, "there was no public provision for education in England, and even now it is only the elementary education of the people that can be said to be regulated by law." ${ }^{1}$ James Russell Lowell speaks of the founders of New England as the inventors of Common Schools, ${ }^{2}$ and says that these schools are defences against " monopoly in Church and state." Sir William Berkeley, one of the early Governors of Virginia, wrote to England, "I thank God there are no free schools or printing, and I hope we shall not have them these hundred years. For learning hath brought heresy, and disobedience, and sects into the world, and printing hath divulged them, and libels against the best government. God keep us from both." ${ }^{3}$ The Dutch Republic, however, had an excellent The common system of common schools; and when Schools of the Pilgrims went to Leyden, they found
the Dutch Republic. a land "where every child went to school, where almost every inhabitant could read and write." ${ }_{4}$ Governor Bradford tells us that they

1 Encyclopædia Britannica, Art. Education, vol. vii. 678 .

2 Among My Books, 242. This statement, however, needs to be modified.

a Campbell's Puritan, vol. i. 32.

4 Motley's United Netherlands, vol. iv. 432. 
were at first unable to establish a school at Plymouth, "for want of a fit person, and also for lack of means to pay a teacher." So the parents taught their own children to read in the first years; but, as soon as they were able, they set up common schools, and required all towns which had fifty families to maintain such schools. The Annals of the Colony are full of references to schools and schoolmasters. ${ }^{1}$ There was a school in Boston five years after the first settlement, of which Philemon Parment was the Schools in teacher. Daniel Maude was his successor, and for his maintenance a contribution of fifty pounds was made by the leading citizens. Governor Winthrop states that " clivers free schools were erected, as at Roxbury, (for the maintenance whereof every inhabitant bound some house or land for a yearly allowance forever) and at Boston, where they made an order to allow forever fifty pounds to the master, and an house, and thirty pounds to an usher, who should also teach to read and write, and cipher; and Indians' children were to be taught freely. Other towns did the like, providing maintenance by several means." 2 In I 647, a general act was passed, which required every town of fifty families or more, to

1 Bradford's History, I6I-I62. Goodwin's Pilgrim Republic, 494-497. Plymouth Records, vol. i. 37.

2 Winthrop's History, vol. ii. 264. 
appoint one to teach all children to read and write; and every town of one hundred families to set up a grammar school, the masters thereof being able to prepare students for the University. Ezekiel Cheever was the earliest schoolmaster in New Haven, and John Higginson the first in Hartford. Every New England Colony, as soon as it was able, provided for the support of schools; "to the end that learning may not be buried in the graves of our forefathers in Church and commonwealth." The movement for universal education was in the air in those years. Wherever the Puritans planted themselves, their social and family life was the life of readers and thinkers. The common school has gone to Virginia now, and far beyond, in disregard of the prayer of the old Tory Governor. The first settlers of these earliest American colonies, north and south, planted the seeds from which their descendants of the seventh generation are reaping. The schools for the people may have brought some heresies, and some disobedience, but they have brought light; they have brought free and liberal thought; they have brought liberty to the slaves, and help to the poor, and light to the ignorant. The common schools made possible the New England town-meeting, - that little congress of the local democracy which was the germ of the republic. 


\section{IX.}

ThE legislation of the Puritans also influenced their social life. Many of their laws, it is true, had the characteristics of the seventeenth century. But, as a whole, their legislation was far in advance of their times. It is common, even now, for writers of limited information to refer to the socalled Blue Laws of Connecticut as specimens of the laws of the Puritans. It is said that the laws contained such provisions as these: No one shall travel, cook victuals, make beds, sweep house, cut hair, or shave on the Sabbath day. No woman shall kiss her child on the Sabbath or Fasting day: no one shall read the Book of Common Prayer, keep Christmas, or Saint days, make minced pies, dance, play cards, or play on any instrument of music, except the drum, trumpet, and jewsharp; no one shall The Blue Laws. run on the Sabbath day, or walk in the garden or elsewhere except reverently, to and from meeting: no food or lodging shall be afforded to a Quaker or other Heretic: every male shall have his hair cut round according to a cap. ${ }^{1}$

It is well known that these Blue Laws were the invention of one Samuel Peters, a Tory, who had

1 General History of Connecticut, by Rev. Samuel Peters, London, $1781,65-82$. 
been driven from the country on account of his disloyalty, during the war of the Revolution. He published in London, in I 7 I, a book which professes to give "A History of Connecticut from its first settlement." The code of laws which this book contains has been proved to be a fabrication. There were no such laws in Connecticut or in any. other part of New England; "nor is there any record of so much as single judgment pronounced agreeably to the tenor of these provisions." 1

Some of the laws which were enacted in New England were like those in force in other parts Laws of the Seventeenth Century. of the Christian world at that time. There were sumptuary laws everywhere; laws to punish those whose religious opinions were different from those of the majority; laws designed to enforce religious duties; meddlesome laws, interfering with small matters, which it is wiser to let alone. There were cruel laws: laws which imposed the death-penalty for offences which we have learned to deal with in another way.

But the laws of New England were more merciful than those of New York, or of Virginia. They were much more merciful than the laws of England. At the end of the reign of Queen Elizabeth, thirty-one crimes were punished with

1 Blue Laws, True and False, by J. Hammond Trumbull, Hartford, $1876,30-32$. Palfrey, vol. ii. 30-37. 
death by the laws of England. Connecticut had only twelve capital crimes in I642, Massachusetts at the same date had ten, Plymouth had only eight. ${ }^{1}$ In England, those who were adjudged guilty of the crime of witchcraft were to be put to death without benefit of Laws of England and of clergy. The writ for burning a lieretic New England. (de haretico comburendo) was not abolished in England till late in the reign of Charles the Second. As late as the time of James the Second, fourteen hundred Quakers were in prison at one time in England, in accordance with the laws then in force in that country. ${ }^{2}$ By the laws of Virginia, Quakers, or other Separatists who should join in religious worship not authorized in England or this country, were, for the third offence, to be banished from Vir-

Laws of England and of Virginia. ginia. $^{3}$ Quakers were to be put to death if they should return a second time. No minister was allowed to hold a religious service unless he had been ordained by a bishop in England. Any person absenting himself from divine service for a month was to be fined; and if he should refuse to pay his fine, he was to be whipped, "on the bare back, ten lashes, well laid on." The penalty for blasphemy, in .Maryland, in I649, was for the

1 Trumbull, Blue Laws, 59. Palfrey, vol. ii. 27, note, 28-31. Body of Liberties, SI-go.

2 Encyclopædia Britannica, Art. Quakers.

3 Jefferson's Notes on Virginia, I67. 
first offence to "be bored through the tongue," and for the third offence it was death."

Some of these seventeenth century laws were enacted in the New England colonies. Some were put in a milder form; many were repealed or greatly modified in a few years. The decided tendency in these colonies was towards softening the penalties or repealing the laws. The reason was that the legislators that enacted all laws were elected by the people in their town-meetings, and these representatives were very susceptible to public opinion. The law which provided that Quakers Laws against who returned to the Colony after they Quakers. had been banished should be put to death, was very unpopular among the people. It has been already stated that it was passed in the House of Deputies by a majority of one rote. ${ }^{2}$ The penalty was executed upon four persons. But the pressure of public opinion against the law was so strong that after three or four years the law became a dead letter, and before many years it was repealed.

The prosecutions for witchcraft, in $169 \mathrm{I}$ and I 692, were brought under an old law enacted fifty witchoraft. $\frac{\text { years before. While the excitement }}{\text { lasted, and within a limited area juries }}$ were found that would convict on such poor testi-

1 Blue Laws, True and False, J. Hammond Trumbull, Hartford, I876, 309-360.

2 Mass. Colonial Records, vol. iv. 346. 
mony as was presented. But public opinion soon condemned the prosecutions, and within a few months it was impossible to find a jury that would bring in a verdict of guilty of Nitcheraft. The people sent such remonstrances to the General Court that the prosecutions were stopped. It was the enlightened judgment of the Puritan Colonists that put a stop to these judicial murders, which were continued in Europe for many years afterwards.

The Puritan legislation was very practical. James Russell Lowell has spoken in emphatic terms of the practical good sense of our fathers. They had been the champions of liberty in England; and they adopted, very early, the Body of Liberties, prepared by Mr. Nathaniel Ward of Ipswich, a man learned in the law, as well as in divinity, which stated in clear and vigorous terms the rights of the citizen under the law. "No man's life shall be taken away; no man's honor or good name shall be stained; no practical man's person shall be arrested, re- Legislation. strained, banished, or anyways punished; no man shall be deprived of his wife or children; no man's goods or estate shall be taken away, ... unless by virtue of some express law of the country, established by the General Court and sufficiently published." 1

1 Body of Liberties, Art. 90-98. 
The laws tended strongly toward democracy. They tended also to protect the family; to secure its purity and its permanence; to restrain vice and crime; to protect the poor and the weak. The laws regulated the sale of intoxicating drinks, perhaps as effectually as our modern laws have done. It is doubtful whether we have made any real progress in respect to that class of legislation, since the time of Governor Winthrop. For many years the General Court assumed the guardianship of widows and orphans, and the care of the insane and other unfortunate people. There were also laws to protect the Indians from injustice, as well as from the tendencies to vice from their contact with unprincipled white men. These laws were designed to aid the missionary work among them.

\section{$\mathrm{X}$.}

LifE in New England was less democratic in the Colonial period than it is in our time. Many of the class distinctions of old England were transferred to the new country. Only twelve of those who came in the Mayflower had the title Mr. prefixed to their names. The others were plain John Alden, Thomas Williams, etc. Only a few of those in the Massachusetts Colony had the prefix Mr., or Mrs. These titles were given to those who had belonged to the class of gentle- 
men in England, and also to ministers, and physicians, and their wives. Goodman and goodwife were the appropriate addresses of persons who were below the condition of gentility, and above that of servants. Most of the deputies to the General Court were designated by their names only, unless they had a military title. A gentleman might be deprived of his rank for a disgraceful act. It was ordered by the Court, in $16_{3}$, that Josias Plastowe shall be fined five pounds for stealing corn from the Indians, and that hereafter he shall be called by the name of Josias, and not Mr. as formerly he used to be. ${ }^{1}$ These distinctions in social rank were carefully preserved in the early catalogues of Harvard College. Those who had been graduated from College were entitled to the title Sir, until they had Aristocratic received the degree of Master of Arts, Distinctions. when their proper title was Mr. People were sometimes seated in the meeting-house according to their social rank. Still, the tendency was towards a free and hearty life, as it is always in a new country. Conventional distinctions faded away, although there were traces of the aristocratic traditions they had brought from England, down to the time of the American Revolution.

1 Winthrop's History, vol, i. 74, note. 


\section{XI.}

The dress of the people during the Colonial period was generally plain, as well because of their limited resources, as because it was the policy of the colonies to discourage the wasting

The Dress of the Early Colonists. of their resources by habits of extravagance. And yet those in official positions were frequently passing to and from England, and it was necessary for them to maintain the style and manners of gentlemen of their rank in the old country. Professional men and public officers were expected to wear a distinctive dress. The typical Puritan, as his appearance is preserved in the old portraits, and in modern statues, looks like a man of distinction. Clothes counted for quite as much in the seventeenth century, as they do now. The Simple Cobbler of Agawam complained of five or six extravagant women in the Colony, who inquire "what dresse the Queen is in this week," and "what is the very newest fashion of the Court," and who "egge to be in it in all haste, whatever it be." "I honor the woman," he says, "that can honor herself with her attire, but for a woman who lives but to ape the newest court fashions I look at her as the very gizzard of a trifle, - the product 
of a quarter of a cipher, - the epitome of nothing." 1

The General Court enacted laws at various times to limit extravagance in dress. The fact that such laws were needed shows that human nature in the times of the Puritans was very much the same that it is now. Their young people had a love for beautiful things; and they sought to adorn themselves, even beyond their means. The younger generation were not inconoclasts. Some of them were disposed to break away from the customs of the pioneers. In 1634 , it was enacted that "noe person, either man or woman, shall hereafter make or buy any apparel that hath lace in it, or silver and gold." It was afterward ordered that no one whose estate is less than two hundred pounds shall wear gold or silver lace, or gold or silver buttons. Still later, it was enacted that no one shall wear embroidered caps, gold and silver girdles, immoderate great sleeves, or slashed apparel. ${ }^{2}$ We read in the Records of the Plymouth Colony of a man who created a sensation by appearing in the streets of Plymouth in long red-silk stockings. ${ }^{3}$ In the inventory of the estate of plain Elder Brewster, we find "one blue cloth coat," one "violet color cloth coat," "one

1 The Simple Cobbler of Agawam, 25-28, I6.7.

2 Colonial Records, vol. i. 273 ; vol. v. 59. Laws, 1634-1651.

8 Records, vol. i. 93. 
green waistcoat." In "New England's First Fruits" it is said: "Linnen fustian we are making already; sheep are coming on for woolen cloth; in the meantime we may be supplied by way of trade from other parts; cordovan deer, seal, and moose skins are to be had plentifully, which will help this way, especially for servants' clothing." ${ }^{1}$ Evidently these pioneers were thrifty people, who respected themselves, and dressed as well as they were able, though they avoided with prudent care habits that were beyond their incomes.

\section{XII.}

THE inventory of the estate of Elder Brewster shows that his furniture was appraised at about Domestic one hundred pounds. The inventory Furniture. of the household goods of Governor Winthrop sums up the value at one hundred and three pounds. This included several feather beds and bolsters worth two pounds apiece; a down bed, pillows and bolsters worth five pounds; a large number of pewter dishes and plates, tin plates, brass and copper kettles, brass candlesticks, brass and iron andirons, some old armor, fire-arms, several small carpets, cushions, cloaks, cloth-ofgold scarf, table-cloths, napkins, a large number

1 New England's First Fruits, ch. xxiv. 
of chairs, tables, cabinets, chests, two suits of clothes worth six pounds, six pairs of spectacles, and many other things.

There is preserved in the Records of the Colony of Massachusetts, ${ }^{1}$ an inventory of the household goods of Mrs. Martha Coytmore, who afterwards became the fourth wife of Governor Winthrop. The whole value of the estate of her first husband seems to have been about thirteen hundred pounds. One hundred and twentyseven pounds of this was represented by the household furniture. The items are much the same as those in the inventory of the furniture of the Governor. Some articles, however, were more expensive. There was a cypress chest worth two pounds ten shillings, diaper table-cloths, with napkins, worth several pounds, a silk red and green quilt, striped curtains, and some silver plate worth fifteen pounds.

These are specimens of the inventories of the estates of persons in the best condition in life, in Boston, twenty years after the town was settled. The furniture in the largest number of houses was much more primitive and of less cost.

1 Records, vol. ii. $234-236$. 


\section{XIII.}

THE amusements of these plain people dwelling in the wilderness were few and simple. And yet they were not as few as some writers would lead us to suppose. It is true that games of chance Amusements of were prohibited by law. No one was the People. permitted to possess cards, dice, or other instrument of gaming. Dancing was also prohibited. ${ }^{1}$ But it is possible for the right sort of people to lead a pleasant social life without gaming or dancing.

The Puritans enjoyed their religion. They delighted in prayer, and in communion with God. They were profoundly interested in religious truth. Religious services were very attractive to them. They were intellectual people. The religious spirit has been found to agree very well with the intellectual spirit. The independent thinkers of New England, as a rule, had a Puritan ancestry.

Our fathers loved their new country, as pioneers generally do. They believed it was better than any other. They were free to work out their own ideas in this new world. They were readers and thinkers. They debated great

1 Records of Mass., vol. i. 84 and 233. Records of Connecticut, vol. i. $2 S_{9}, 527$. 
questions under the shadows of the primitive forests. They did not feel the need of the pleasures which people of less intellect and less faith seem to require.

There is abundant evidence that there was a genuine, hearty, social life in these colonies. Travellers of that period, who came to New England, do not speak of the life they found here as a gloomy life. The people were interested in each other. They had their own simple rustic amusements such as those to which they had been accustomed in England.

Take as an example the first Harvest Festival at Plymouth. The Pilgrims had gathered their first harvest, after the year of severe labor and privation, while they were building their houses, and breaking up the ground, and caring for their crops. The harvest was bountiful, and they had at last a right to give themselves up to recreation. We read, in Mourt's Relation: "Our harvest being gotten in, our Governor sent foure men on fowling, that we might after a more special manner rejoice together, after we had gathered the fruit of our labors. They foure in one day killed as much fowle, as, with a little help beside, served the Com- Harvest Festival pany almost a weeke, at which time, at Plymouth. amongst other Recreations, we exercised our Arms, many of the Indians coming amongst us, 
and amongst the rest, their greatest King, Massasoyt, with some ninety men, whome for three dayes we entertained and feasted, and they went out and killed fine Deere, which they brought to the Plantation, and bestowed on our Governor, and vpon the Captaine, and others." 1

This was not a religious festival. There is no mention of any religious services. The week seems to have been given up to sports, and a succession of festivals, as well as to the entertainment of their dusky neighbors. In these ways, these vigorous men enjoyed themselves, making the best use of their limited opportunities.

In Massachusetts, there was a larger population, and a greater variety of occasions of interest. The house of Governor Winthrop was seldom without its guests. There were interesting people coming from abroad, whose presence added interest to the home-life. The Commencement week at the new college was always interesting. We read of a great training on Boston Common, which brought together the people from the various settlements. Many gentlemen and gentlewomen clined in tents on the Common. Judge Sewell, in his Diary, refers very often to the dinner parties which he attended. He sometimes gives us the names of

1 Mourt's Relation, I33. 
the guests, and tells us something of the bill of fare. The picture of a New England Holiday, in the "Scarlet Letter," with its mingled light and shade, gives a very fair impression of life in those days. Hawthorne says, very truly, that the generation next to the early emigrants - who had never mingled in the sports of Old England wore the darkest shade of Puritanism. ${ }^{1}$

Human nature in the colonies was very much like human nature in the rest of the world. The amusements of the young people were not always such as their fathers and mothers approved. There are numerous records of "Mixt dancings, unlawful gamings, extravagence in dress, light behavior," and such like offences. These things do not appear to have been confined to any one period in our history. They became more frequent as the colonies became richer and more populous. The family discipline was careful and faithful, but the habits and characters of the children did not always develop according to the Puritan model.

\section{XIV.}

WE may draw another class of illustrations of the social life of the Puritans from their intercourse with the French, whose settlements in

${ }^{1}$ Hawthorne's Scarlet Letter, 270-290. In some of his other books, Mr. Hawthorne fails to do justice to the Puritans. 
the north were older than those of the Puri-

Intercourse

with the

French. tans. The French officials were zealous Roman Catholics, and their habits were very different from those of the Puritans.

In 1643, La Tour arrived in Boston harbor with his ship, and a hundred and forty people, among them two Friars, and two women who were to wait upon the wife of La Tour. They were courteously received by Governor Winthrop, who escorted La Tour to his lodgings on shore, "with a sufficient guard." While the Frenchmen were in the town the training day came on, and La Tour witnessed with pleasure the evolutions of the citizen-soldiers. In the afternoon, the French soldiers were landed, with their arms, and they were permitted to exercise, "The Governor and others of the Magistrates coming into the field." The Puritan soldiers escorted the Frenchmen to the landing-place. "Our Governor and others in the town," we are told, "entertained La Tour and his gentlemen with much courtesy, both in their houses and at table. La Tour came duly to our church meetings, and always accompanied the Governor to and from thence, who all the time of his abode here was attended with a good gruard of halberts and musketeers." There were animated discussions among the people 
in regard to the propriety of receiving these "idolatrous Papists," as some called them, with so much honor. But the majority approved the wise and courteous course of the Governor. There was a good deal of social intercourse between the people and the French. We read: "Of the two Friars which came in this ship, the one was a very learned acute man. Divers of our Elders, who had conference with him, reported so of him. They came not into the town, lest they should give offence, but once, being brought by some to see Mr. Cotton and confer with him, and when they came to depart, the chief came to take leave of the Governor, and the two Elders of Boston, and showed himself very thankful for the courtesy they found among us." ${ }^{1}$ This picture of the learned Friar, calling on John Cotton, to "confer with him," being brought by some of the Puritans, is one of the evidences that there was a place for courtesy toward those of another faith, among those stanch Protestants.

Three years later, another company of Frenchmen came to Boston. They arrived on the Lord's-day. "Major Gibbons sent two of his chief officers to meet them at the water side, who conducted them to their lodgings, sine strepitu. The public worship being ended,

1 Winthrop's History, vol. ii. I28-13S, 153. 
the Governor repaired home, and sent Major Gibbons with a guard of musketeers to attend them to the Governor's house, who, meeting them without his door, carried them into his house, where they were entertained with wine and sweetmeats, and after a while, he accompanied them to their lodgings. The Governor explained to them the Puritan way of observing the Lord's-day, 'that all men either come to our public meetings, or keep themselves quiet in their houses.' The French Catholics complied with the customs of the Colony, for 'they continued private all that day until sunset, and made use of such books, Latin and French, as the Governor had, and the liberty of a private walk in his garden, and so gave no offence.' When they had finished their business, they were attended to their boat by the Governor, and the Commissioners of the Colony. When they sailed for home, they were saluted with five guns from Boston, three from Charlestown, and five from Castle Island. They returned the salute, and went of their voyage." 1

A still more interesting incident occurred four years later. Father Gabriel Druillette, a Jesuit missionary among the Abenaquis, in what is now the State of Maine, was sent by the Governor of Canada, D'Ailleboust, as a diplomatic agent to

1 Winthrop, vol. ii. 334-336. 
Massachusetts, and to Plymouth. His purpose was to engage the Colonies in alliance with the French, against the Iroquois. The Jesuit missionary hoped by such an alliance to secure protection for the

Visit of Father Druillette, I650.

Christian Indians, against their savage enemies. He has left a journal of his visit, in French, which was published some forty years ago. ${ }^{1}$

Druillette reached Boston in December, I650. $\mathrm{He}$ was known as a zealous Jesuit missionary. He was received with great courtesy and respect. He was invited to the house of General Gibbons, who charged him to make no other house his home, while he remained there. The General gave to his guest a key to an apartment in his house, where he might be free to pray, and to go through the services of his religion. It has been suggested that the first Mass in Boston may have been solemnized in that room. General Gibbons presented his guest to Governor Dudley, who examined his credentials, and invited him to dine at his house. From Boston, Father Druillette went to Plymouth, where he was courteously received by Governor Bradford, who invited him to dine at his house the next day. As the next

1 Narré du Voyage faict pour la Mission des Abnaquiois, et des Connaissances tirez, de la Nouvelle Angleterre et des dispositions des Magistrats de cette Republique pour le secours contre les Iroquois, ès annees I650 et 165I. Par le R. Père Gabriel Druillette, de la Compagnie de Jesus. Quebec. 
day was Friday, the Pilgrim Governor provided fish for dinner, in recognition of the religious customs of his Jesuit guest. The Priest found favor among the people of Plymouth, although the Magistrates did not embarrass themselves by entering into the alliance which he proposed. On the 24th of December, the good missionary started on his return to Boston by land. On his way back, he called at Roxbury on John Eliot, the Puritan missionary among the Indians. It must have been about the time of Christmas day. He writes in his journal that Eliot invited him to lodge with him, as the night had overtaken him. These two missionaries - the Jesuit, and the Puritan - had much discourse concerning their work among the Indians. "Here is a scene," says Dr. Ellis, "that might well engage the pencil of an artist. These two men, ... separated as the poles in their religious convictions, principles and methods, are seen in simple, human, loving conJohn Eliotand verse, as kind host, and responsive John Eliot and
the catholic stranger guest. The humble sitting
Missionary. and working room of the Apostle Eliot, in his modest cottage, has the essentials of comfort, and there is a guest chamber:" The Priest writes in his journal that Eliot treated him with respect and affection, and invited him to pass the winter with him. "Perhaps their conversation was in Latin," says Dr. Ellis, "though Eliot was 
an accomplished scholar, and might have the mastery of the French. The morning and evening devotions of the Puritan household, with grace and blessing each meal must have kept their wonted course, while the faithful Priest had his oratory, - his orisons, - and his matin Mass before breaking his fast." ${ }^{1}$

So nearly do good people of different creeds approach each other, who are devoted to the service of the one Lord, and to the salvation of their fellow-men.

\section{XV.}

LAST of all, we can estimate the social and family life of the Puritans, from its results, in the types of character which we find in their descendants. We are living among people of the seventh and eighth generation from the founders of New England. That is a long period through which to transmit distinctive traits. Mr. Galton, in his work on Hereditary Genius, tells us that "the ablest race of whom history bears record is unquestionably the Ancient Greeks." ${ }^{2}$ But the Greek type, which was preserved for a few centuries, became gradually feebler, and was long ago lost. The Patricians at Rome were as distinctly

1 Palfrey, vol. ii. 305-30S. The Puritan Age and Rule, by George E. Ellis, $366-374$.

2 Hereditary Genius, 329. 
marked in their time, but Gibbon tells us that at the time of the Republic most of the Patrician families had failed, and that the type was lost. Mr. Benjamin Kidd states that "only five out of over five hundred of the oldest aristocratic families in England, at the present time, can trace direct descent through the male line, to the fifteenth century." 1 "Despite the immeasurable safeguards with which they have been able to surround themselves, such classes seem to be quite unable to keep up the stock for more than a limited number of generations. They are continually dying out at the top, and being recruited from below." A similar state of things has been found to exist in France among the noble families of that country.

The Puritan type in this country has met a number of other vigorous types, each of which has moulded a large number of our people. Beside the Cavaliers of Virginia, who made the Church

The Puritan Type in the United States. of England the established Church in that Colony, there has been the Scotch, and the Scotch-Irish type, out of which has come the great Presbyterian Body. The French Huguenots have been very numerous. So have the Dutch, and the Germans. There has been a mingling of blood. Each type has exerted an influence upon the others, and there is a tendency to melt down these distinctive

1 Social Evolution, 277. 
types in the comprehensive national spirit and character.

But for all that, the New England type of mind, after two hundred and seventy years, is still as distinct in the great stream of our American life, as the Gulf Stream in the Atlantic. A large fraction of the people of the United States have sprung from those who settled the colonies of New England. They are to be found in every State, and in almost every city and town. The men and women of Puritan blood, wherever we find them, are apt to be people of vigorous intellects, of thrifty habits, of inventive genius, and of strong moral character. They stand for liberty in the Church, and in the state. The leaders of liberal thought have been descendants of the Puritans. A large proportion of the great conservative leaders have also been of Puritan lineage. I find these men in the South, and in the extreme West, as well as in the East. They are preaching in California and in Oregon. They are Senators and Representatives from Colorado, and from Michigan: from Washington, and from Ohio; from Wisconsin and from Illinois. President John Adams and President John Quincy Adams, and the poet Longfellow were among the descendants of John Alden and of Priscilla Mullins. Ralph Waldo Emerson was of the eighth generation of Puritan ministers. Nathaniel Hawthorne 
was a descendant of William Hawthorne, who came to America with Governor Winthrop, and who settled in Dorchester, in 1630. James Russell Lowell was a descendant from Percival Lowell, a prosperous merchant, who settled in Newbury, in 1639 , and of the long line of his successors, merchants and lawyers and ministers.

I have before me, as I write, a list of a hundred and twenty-five men who have died within the last three years, and who were members of the New England Historic Genealogical Society of Boston. They were not selected men, excepting that they were especially interested in the history of New England families. The majority of them were residents of Massachusetts, but a large number lived in other parts of New England, and in other sections of the country, and some in foreign lands. There are among them descendants of the French Huguenots, of the Scotch, the Dutch, and the English. It has been found, from an examination of this list of a hundred and twenty-five members of this Society, who have died in 1893,1894 , and I 895 , that about two-thirds of them were able to trace their descent from the Pilgrims or the Puritans of New England. The list includes such names as William Frederick Poole, the Librarian of Chicago, Joseph H. Stickney, a merchant of Baltimore, Thomas E. Proctor and Benjamin F. Nourse of Boston, both successful 
business men, and both descended from persons who were put to death in Salem at the time of the witchcraft delusion, Ex-Governor Oliver Ames, and Frederick L. Ames, and Waldo Higginson, Moses Kimball, Gyles Merrill of Haverhill, Warren Ladd of Providence, Judge Charles C. Baldwin of Cleveland, Elisha C. Leonard of New Bedford, James R. Newhall of Lynn, Dr. Henry Delevan Paine of Albany, Daniel Clapp, Peter Butler, Peter Thacher, James W. Austin, Francis G. Pratt, and many others of Boston. These are representative men, specimens of the thousands of men in active life who are of Puritan descent, whom one may meet from day to day in business or in professional life.

Phillips Brooks was one of these representative men, a descendant on his father's side from Thomas Brooks, and on his mother's side from George Phillips, the first minister of Watertown. Three generations ago one of the descendants of John Cotton became the wife of the great grandfather of Phillips Brooks. So that he came from at least three lines of Puritan ancestors, - Cotton, Phillips, and Brooks. He showed what a well developed Puritan of the seventh generation may become under favorable circumstances. Francis Parkman, LL.D., the eminent historian of the French in America, who died in I893, traced his family line to Elias Parkman, through a long suc- 
cession of ministers and men of letters. Judge Peleg Emery Aldrich, who has only recently passed away, was only one of the many eminent descendants of George Aldrich of early Puritan times. Henry Oscar Houghton, the eminent publisher, was of the seventh generation from John Houghton. Leverett Saltonstall was descended from Sir Richard Saltonstall, the leader in the settlement of Watertown. He was the sixth in lineal descent to graduate from Harvard College. Dr. Andrew P. Peabody was a descendant of the seventh generation from Lieut. Francis Peabody, and from a long line of New England ministers. Dr. Alonzo A. Miner was of the seventh generation from Thomas Miner, who came to Boston in 1630 . Robert C. Winthrop, LL.D., so eminent as a statesman, an orator, and an author, was of the sixth generation from the great Puritan Governor, John Winthrop. There have been eminent men in every period of the history of the Winthrops, but none have been more admirable than the eminent man who has so lately passed away. ${ }^{1}$

The Puritan discipline was undoubtedly severe, but it trained men for heroic action. That social and family life of theirs is still bearing fruit. The Puritan type is very persistent. No other section

1 Proceedings of the New England Historic Genealogical Society, IS94-5-6. Genealogical Register, I893--96. 
of the Anglo-Saxon race has excelled the Puritans in the number of great men and of good men, soldiers and statesmen and scholars, that it has produced. Whether the social and family life of the present generation in New England is likely to preserve the type for other generations is an interesting and important question. 



\section{VI.}

Religious Opinions of the Fathers of New England. 


\section{Religious Opinions of the Fathers of New England.}

$\mathrm{W}^{\mathrm{E}}$ shall fail to understand the Puritans unless we know what views they adopted in regard to religious truth. For their whole tone and spirit, and their methods of life, were the outgrowth of their religious opinions. Like a great poet of our time, "they believed in the soul, and were very sure of God." They knew that He was not far from every one of them. Duty to God was their highest rule. Religious motives had the largest place in their lives. They had crossed the sea that they might be free to follow their convictions of duty. The larger number of them had been in a condition of comfort in England; some of them had been affluent. The early years of the reign of Charles the First had been times of great prosperity for those who could fall in with the teachings of the Established Church and with the views of the court. But they had left their English homes behind them, that they might be free to follow their religious convictions. 


\section{I.}

The Puritans were, first of all, Protestants. They lived to protest against error and to bear

The Puritans were Protestants. witness to the truth. Their Protestantism was of that intense and aggressive type, which generations of conflict with the Church of Rome had developed.

As Protestants they appealed to the Bible as the only infallible rule of faith and of duty. They asserted its authority in opposition to that of the traditions of the Church. But, in the interpretation of the Bible they insisted upon the right of private judgment. They denied the right of the Church, or of the councils, to give them an interpretation of the Word. A Puritan was a man who submitted with meekness to the teaching of God's word, as he understood it.

As consistent Protestants, the Puritans gave great emphasis to the doctrine of justification by faith. They guarded very carefully, in their teachings, against the covenant of works. They would not admit that there was any merit, as a ground of justification, in the best actions of the holiest men.

The Puritans derived from their study of the Bible a new sense of the sanctity of the Lord'sday. It was from the Puritans that the English 
people learned to keep the first day of the week so strictly that, even now, their habits of Sabbath observance are in marked contrast with those of the other nations of Europe. The Puritan clergymen would surrender their livings sooner than sanction the proclamation of the king, which required the people to devote a part of the day to amusements. The King's Book of Sports served the purpose of separating the Puritans from the other classes of their countrymen. One of the leading motives in the great Puritan migration was the desire to establish the habit of the strict observance of the Lord's-day among their children.

The whole tone and spirit of New England during the first generation was unworldly, to a remarkable degree. There was a good deal of propriety in calling their state a theocracy. The sermons of the seventeenth century were longer and more abstract than those of our time. Many of them consisted of close and logical discussions of the doctrines of the Bible. Some of them were sections of theological treatises. Willard's Body of Divinity deserves to rank high among the theological works of New England; but it consists of two hundred and forty-six sermons. The first of them was preached January 31,1687 ; the last, April r, I 707, - an interval of twenty years. John Norton's theological works were given to 
his people in the form of sermons. So were those of John Cotton and of Thomas Hooker.

The few books which the Colonists were able to have in their homes were, for the most part, theological. They became as skilful as the Scottish people in theological discussion. They were as quick to detect any departure from the standards of doctrine which they had accepted, as the Athenians were to detect faults of pronunciation, or of style, in their orators. In those periods of their history there was good reason for the practice of preaching as candidates, for there were persons in every congregation who were qualified to form an intelligent opinion of the correctness of the teaching of the preacher. The great doctrines of religion were living themes for the people, the subjects of discussion at the fireside, in the market, and at all social gatherings.

\section{II.}

Among Protestants, the fathers of New England belonged to the Reformed instead of the Lutheran branch of the Church, and to the Calvinistic instead of the Arminian party. The Pilgrims, who settled the Old Colony, had been trained under John Robinson, who was an able defender of the decrees of the Synod of Dort against the Arminians. The Puritans of the Bay Colony found the 
standards of the Westminster Assembly the best exponents of their faith. $U p$ to the time of the Westminster Assembly, there does not the westseem to have been much discussion minster conamong them as to the particular shade catechisms. of Calvinism they would teach. Their theology, like their religion, had been shaped by the hard experiences of their lives. It may be that the religion of the camp is not quite the same as that of the firesicle. The Puritans desired to exalt the sovereignty of God, for they believed He had chosen them for a great mission, and they depenced utterly upon Him for protection and success. Many of those who had been driven from England had spent years in Geneva, and they had been influenced by the decided Calvinistic teachings of the ministers of that city. There was a difference among them, as to some points in the system, but the tendency during the first two generations was toward a very high type of Calvinism.

\section{III.}

THe books that were written in New England, in the first period, related to the organization and discipline of the churches, rather than to theology. "The Way of the in the Polity Churches," "Necessity of Separation," "Why Ruling Elders should be Chosen," "The 
Necessity of Infant Baptism," "Should those not in Covenant with the Church present their Children for Baptism?" - these are specimens of the titles of the early pamphlets. When the Synod was convened at Cambridge, in 1646, it devoted itself to the Platform of Church Government, instead of the construction of a New Confession of Faith. The reason was that they were content, for the most part, to accept the Westminster Confession; but they felt the need of rounding out and completing that form of Church polity which had grown up in New England.

\section{theulogy. IV.
Tue Puritans were always, however, deeply in-} terested in theology. What their views were, we may learn from the catechisms which they taught their children, as well as from the creeds of their churches, and from the books which they published.

- That famous catechism, prepared by John Cotton, in I64I or I 642 , at the request of the General Court, entitled "Milk for Babes," which was in common use for about a century, although it deals, Milk for Babes. for the most part, with practical matters of duty to God and to men, yet sets forth quite distinctly the doctrine of the Trinity, of the Fall of Man, asserting that "we sinned in 
Adam, and fell with him," and also that his $\sin$ is imputed to us; that the wages of $\sin$ is death; that "faith is a grace of the spirit whereby I deny myself, and believe on Christ for righteousness and salvation." The rhyming couplet in the New England Primer :

$$
\text { "In Adam's fall, }
$$

is not unlike the teachings of this catechism, in which several generations of Puritan children were trained.

- Those who were admitted as members of the Puritan churches were required to give to the

church an account of their religious experiences, and also of their "knowledge in the principles of religion." This "knowl- Religious edge" included a statement of what Experiences. truths and principles they had deduced from the Scriptures. ${ }^{1}$ It is clear from the early pamphlets that our fathers regarded the knowledge of the great principles of the Christian religion as an important preparation for admission to the church. The examination of the candidates as to their "knowledge of the principles of religion" led, in the course of time, to the adoption of a creed by the Church. Thus, the church in Salem, which

1 These points are fully discussed by Professor Williston Walker in his Creeds and Platforms of Congregationalism, 107, notes. He quotes the original authorities. 
was the earliest in New England, next to the Pilgrim church in Plymouth, had originally only this simple covenant: "We covenant with the Lord, and one with another: and do bynd ourselves in the presence of God, to walke together in all bis covenant and waies, according as he is pleased to Creed of the reveale himself unto us in his Blessed
church in Church in word of truth." As time went on, it was found expedient to expand this covenant, and make it more specific. In I665, a formal creed was set forth with this title: "A Direction for a Public Profession in the Church Assembly, after private Examination by the Elders: which Direction is taken out of the Scripture, and points unto that Faith and Covenant contained in the Scripture; being the same for substance which was propounded to and agreed upon by the Church of Salem in their beginning, the sixth of the sixth moneth I629." This ancient Confession of Faith sets forth the doctrine of the Trinity; of God's providence and government of the world; the fall of man; the redemptive work of Christ, who "became man that he might redeem and save us by his obedience unto death;" of the Holy Spirit; who, "working Faith in God's Elect, applyeth unto them Christ with all his Benefits of Justification, and Sanctification, unto Salvation."

The history of the first Synod called by the General Court of Massachusetts, which met in 
what is now Cambridge, in $16_{37}$, gives some intimations of the discussions which went on among the Colonists in the earlier years. ${ }^{1}$ Those were the days of Mrs. Hutchinson, who came to Boston in 1634. The questions which were the First raised by her bold teachings, set the $\underset{\text { Hutchinson, }}{\text { Syyon }}$. whole Colony in a turmoil. The Synod ${ }_{1634-38}$. chose Thomas Hooker, and Peter Bulkly moderators, and proceeded to consider eighty-two erroneous opinions which had been set forth in this country at various times. One would think the Synod had abundant work on its hands, for the twenty-four days of its session. Most of these errors were traced to the teachings of Mrs. Hutchinson. It is plain that the intense religious spirit of the people had led them to speculate very freely with reference to the questions which had been raised by their new teachers. Some of their speculations were crude, and some, in the opinion of the Synod, were subversive to the fundamentals of religion. Cotton Mather states that they were of an Antinomian and Familistical tendency. The Synod dealt with these errors one by one. After stating the erroneous opinions, they would say, "This is contrary to such and such texts of Scripture," and this, according to the author of the Magnalia, did "smite the error under the fifth

1 See Winthrop's History, vol. i. 294-28s. Three Episodes of Massachusetts History, IS92. Charles Francis Adams. 
rib." The influence of this Synod tended to harmonize the opinions of the people. In ${ }_{16} 6_{37}$, however, the General Court of Massachusetts banished Mrs. Hutchinson and some of her supporters from the Colony. ${ }^{1}$

About the time of the Westminster Assembly, there was, as we have seen in the sketch of MIr. Pynchon's Dis- Pynchon, ${ }^{2}$ more or less dissent from cussion of the some of the statements, which it was
Price of Redemption. then common to make, in regard to the Atonement. Mr. Pynchon did not stand alone in his denial of the dogma of strict satisfaction. Some of the leading men among the Puritans in England were in sympathy with his views. But the larger number were against him. The reply to his book, by Mr. John Norton, asserted in the plainest terms that the Redeemer suffered the punishment which the sinner deserved to suffer. Mr. Norton did not hesitate to affirm that $\mathrm{He}$ suffered the torments of the souls that are lost. Both parties in this great debate imply that the Atonement of Christ is limited to the elect, and that there is no provision for the salvation of those whom God has not chosen unto salvation.

1 See Mather's Magnalia, vol. ii. 508-515. Felt, vol. i. 313-319. Walker's Creeds and Platforms, I33-1 35.

2 See pages $20 \mathrm{I}-2 \mathrm{I} 2$ of this volume. 


\section{V.}

THE meeting of the Cambridge Synod, in 1646 to $\mathbf{I} 648$, was a very important event, not only because it led to the adoption of the Cambridge Platform of Church Government, but because the Synod aclopted,

The Westminster Confession of Faith.

for the first time, in the name of the churches of New England, a standard of doctrine. In the preface to the Platform the Synod declares: "Wee beleive \& profess the same Doctrine of the trueth of the Gospell, which generally is received in all the reformed Churches of Christ in Europe: so especially, we desire not to vary from the doctrine of faith, \& truth held forth by the Churches of our native country." It is further stated in this preface, that the Synod roted unanimously, "the last of the sixth month 1648, in these words: This Synod, having perused, and considered the Confession of faith publişhed of late by the Reverend Assembly in England, doe judge it to be very holy, orthodox, \& judicious in all matters of faith: $\&$ doe therefore freely $\&$ fully consent thereunto, for the substance thereof." " These declarations of the Synod had an important influence upon the theological dis-

1 Walker's Creeds and Platforms, 194-196. 
cussions of the New England divines for the next half century, as we shall see from such of their works as have come down to us.

\section{VI.}

Within a few years after the time of the Cambridge Synod, a number of theological books were produced in New England, which were the first fruits of our literature, and which are the most authentic statements of the teachings of the early divines of New England.

Thomas Shepard, the first pastor of the church in Cambridge, left a number of works which show how an active pastor, and an earnest preacher, understood the doctrines of the Gospel. Mr. Shepard was born in Northamptonshire, in $\mathbf{1 6 0 5}$, received the degree of B.A. from Emmanuel College, Cambridge, in 1623 , and that of M.A. in 1627 . He received deacon's orders, and was appointed to one of the Puritan lectureships, in Essex, with a salary of $£, 30$ a year. ${ }^{1} \quad H e$ was permitted to labor in that place about three years and a half, when he was silenced by Bishop Laud, and driven out of the diocese. After incredible sufferings from persecution, during the next four years, he made his escape in disguise, and sailed for New

1 Shepard's Works, Doctrinal Tract and Book Society, Boston, I 853 . 3 vols. vol. i. lxx. Cromwell's Letters and Speeches, by Carlyle, vol. i. 50. 
England, in 1635 . The next year, the Church in Cambridge was formed, and Mr. Shepard was ordained as the first pastor. That was the year in which Harvard College was founded in Cambridge. Mr. Shepard deserves to rank with Cotton, and Hooker, and Mather, among the leading ministers in the Colonies. His works belong to the first generation, for he died in 1649 . "God's decree," he says, "is His eternal and determinate purpose concerning the effecting of all things, by His mighty power, according to His counsel." And yet, as a preacher, Mr. Shepard held to the freedom of the will. "In the fall," he tells us, "man abused his own free will, in yielding to the temptations which he might have resisted." The sin of Adam "is imputed unto us, and so the punishment must needs follow upon it." ${ }^{1}$ $\mathrm{He}$ reasons in the usual manner in regard to this imputation. "We were in Adam, as the members are in the

Theology of

Thomas

Shepard. head, - as children in his loins, - as debtors in their surety, as branches in their roots: it being just that, as, if he standing, all had stood by imputation of his righteousness, - so, he falling, all should fall by imputation of his sin." So he declares that "every man living is born guilty of Adam's sin." ${ }^{2}$ "The justice and equity is this :All our estates were contained in that ship."

I Works, vol. i. 335-35r.

2 Ibid., 24. 
"We were all in Adam, as a whole country is in a Parliament man, and though we made no agreement to have Adam stand for us, yet the Lord made it for us."

Passing next to Redemption, he tells us that, "It is the satisfaction made, or the price paid to the justice of God, for the life and deliverance of man out of the captivity of sin, Satan, and death, by a Redeemer, according to a covenant made between Him and the Father." So it came to pass that "Christ stood in the room of all them whom mercy decreed to save." "Justification is the gracious act of God, whereby, for the satisfaction of Christ, apprehended by faith, and imputed to the faithful, He absolves them from the guilt and condemnation of all sin, and accepts them, as perfectly righteous, to eternal life." "Faith is the first act of our spiritual life, whereby, the soul, believing God, believeth in Him, and thus resteth, as in the only author and principle of life." I In this passage he teaches that faith is an act of the believer. So he taught that the sinner is free in his rejection of Christ. "The cause of this ruin," he says, "is from themselves." As a practical preacher, Shepard found it important to teach this truth with great earnestness. It is very plain, that those old Calvinistic preachers tried to develop a sense of freedom and of responsibility among those to whom they were preaching.

1 Sum of the Christian Religion. 


\section{VII.}

THE Orthodox Evangelist, by John Norton, of Ipswich, is one of the oldest elaborate theological works of the New England divines. It was published in London, in I654. The original edition contains three hundred and fifty-five pages, and was written for The Orthodox the use of thoughtful laymen in the John Norton.

Puritan churches. The author was a preacher and pastor, as well as a well-read theologian. After a very subtle discussion of the essence of God, and of His attributes, he proceeds to His eternal decrees.

"The decree of God," he says, "is God's one, eternal, free, constant act, absolutely determining the infallible being of whatever is, besides Himself, unto the praise of His own glory." $\mathrm{He}$ says, with Calvin: "God willeth by one single act. With Him there is nothing past, - nothing to come, but all is present. Whatever He thinks, He always has thought, and always doth, and will think. There can no more be a new thought, or purpose, than a new God." " "The decree of God is the antecedent of $\sin$, but it is not the cause of sin." "God is free from any motive besides His own will." "God is essentially

1 Orthodox Evangelist, 5I, 52. 
good:- He is goodness itself." "All goodness cometh from Him." "God is a full fountain; willing to communicate of His goodness, as the sun communicates of its light." 1 "The will of God is the rule of justice between $\mathrm{Him}$ and His creatures. The holiness of God is conformity unto Himself." "2 "The justice of God leads Him to render unto the reasonable creature what is due thereunto, according to His word, whether by way of grace, or punishment."

In respect to man, he says: "The liberty of man, though subordinate to God's decree, freely willeth the very same thing, and no other, than that which it would have willed, had there been no decree. Man acts as freely as if there were no decree. Liberty is the effect of the decree; so far is the decree from being a hindrance to liberty." 3 In the same connection, he says: "All who hear the gospel, are equally bound to believe. How can God command those to believe, whom He hath decreed that they shall not believe?" "Hope is grounded upon God's revealed will, not upon the decree that is unrevealed." "Every person that heareth the gospel is equally capable of believing. We are to look upon all those living under the gospel as elected, in the judgement of charity. It is the duty of

1 Orthodox Evangelist, 12.

2 Ibid., I6.

8 Ibid., 76. 
every one to believe." 1 "It is a sin for any to conclude in this life that he is among the reprobate."

He agrees with the other Calvinists of his time in respect to the fall of man, and the consequences of the fall. "Adam, being a public person, his posterity, in a seminal respect, was contained in his loins, and so sinned in him sinning." "Adam might not have sinned; and yet, it could not be but that Adam should sin. Both of these are true." 2 "Necessity and liberty consist together." "God imputes the guilt of his $\sin$ to all his posterity." "Original $\sin$ is propagated in the soul by reason of the sin of Adam." ${ }^{3}$ "The soul contracts $\sin$, by its connection with the body, as when one falls into the dirt, he is defiled, and besmeared." "God, whiles $\mathrm{He}$ creates souls, doth deprive them of original righteousness." 4

And yet he teaches that "the Parable of the Prodigal Son's return unto his father's house is proposed as the pattern of the sinner's being brought home unto Jesus Christ. The younger son was sensible of his lost condition before he was found." ` Still, "the elect's seeking God, is the effect of God's seeking them. Our seeking before faith is the effect of the common work of the Spirit: our seeking after faith is the effect of
1 Orthodox Evangelist, I95-200.
3 Ibid., I 43.
4 Ibid., I 40-I 44.
2 Ibid., 74.
5 Ibid., I3S. 
the saving work of the Spirit." " The Arminians tax the Orthodox for asserting all acts before faith to be sin; and they pretend that there is in man, before regeneration, a hunger and thirst, after righteousness, and a hatred of sin. They say that to all such God giveth sufficient grace to believe. But this is contrary to the Scripture." 2

"Saving faith is an impulse or motion of the spirit of grace. It enables the soul to yield obediIrresistible ence unto the commands of God." 3 Grace.

"The soul is passive in vocation; that is, in the infusion of the principle of life." 4 "The manner of working of faith is irresistible, that is, it prevaileth over all opposition." But there are certain means of obtaining faith; such as "God's love to men, and Christ's work for sinners, and the invitations of the gospel." 5

"Justification is a gracious act of God upon a believer, whereby he doth freely discharge him from $\sin$, and accept him as righteous with the righteousness of Christ, and acknowledge him to have a right to eternal life. The efficient cause of Justification is the good pleasure of God.." 6

These citations are sufficient to show the method of this most logical of the early divines of New England. Undoubtedly, he held firmly
1 Orthodox Evangelist, 159.
2 Ibid., I66.
3 Ibid., 220.
4 Ibid., 257 .
5 Ibid., 213, 214.
6 Ibid., 300. 
the system of John Calvin, in all its essential points. And yet he sought constantly to guard against the tendency of that system to a denial of human freedom, and of personal responsibility. He made much of the free love of God, and of the motives of the Gospel. It is plain that his methods of thinking as a logician were very often modified by his moral instincts as a preacher.

A greater man than John Norton, was the learned and accomplished Thomas Hooker, whose moving eloquence in the pulpit was equalled only by his statesmanship. Hooker was the author of a large number of religious books, which contain altogether more than two thousand pages. These were printed at various times between 1637 and $165 \mathrm{I}$. One of them was printed in Amsterdam, $\begin{aligned} & \text { Thomas Hooker, } \\ & \text { the Preacher }\end{aligned}$ the others in London. We find in and Practical these books the theology of Calvin,

concerning the decrees, the fall of man, original sin, inability, irresistible grace, and the perseverance of the saints. This theology, however, is used in a practical way, and accommodated to the exigencies of the preacher. There are hints in these volumes of the distinction between natural and moral ability, which President Edwards brought out a hundred years later. Hooker teaches that man is free, and therefore fully responsible. He makes much of the abound- 
ing love of God, and of the free and hearty offers of divine grace.

His longest work is entitled "The Soul's Vocation, or Effectual Calling to Christ," published in London in 1638 , and contains six hundred and sixty-eight pages. He says : -

"The offer of grace from God is free: the means of grace are also free: grace must be free because there is nothing in man to purchase it: and because he can do nothing to merit it. The saints should therefore magnify the mercy of God. The wicked, that want this mercy, should take encouragement, and seek after this mercy, seeing it is free. Those burdened under their sins should hope for mercy from the freeness of it. The soul must be willing to recieve Christ and grace before it will have Christ and grace." 1

"The will is the natural power or faculty wherewith every one is endowed to will." "The will is the hand of the soul. But the hand must turn towards the object, The Saint's and open itself before it can grasp its object. Vocation.

So a man must turn his will towards an object and open itself. The hand of the soul must be open, before it can close with and fasten upon a thing. When the soul opens the hand to catch at grace, and lay hold thereupon, then it wills to receive grace. So, when we are unwilling to receive a thing, we turn away our hearts from the thing. When the soul is unwilling to receive anything, it shuts itself against that thing, and will by no means receive it." 2 "Whosoever in truth doth will to have Christ, shall receive him." 3

1 The Soul's Vocation, I-23.

2 Ibid., 3 I.

8 Ibid., 54 . 
"No man, of himself, by nature, can will to receive Christ. A natural man hath no power to receive Christ, as we learn from I Cor. ii. I4. The natural man is unwilling to be wrought upon, that he may be made capable to receive the grace of God." 1 "While life is continued, and the means of grace afforded to a people, that is the season wherein God meaneth to lead the soul to recieve life and salvation." 2

This passage is followed by a most earnest and tender appeal to the hearers to give themselves up at once to the Saviour, who is even now waiting for their acceptance.

In another volume, Hooker says :-

"Every man in his natural state is fastened and settled in sinne and corruption. They are in slavery to sinne. But God draws the hearts of sinners, first, by giving them light; then by the manifesting of His mercy, namely, by his readiness to receive sinners, by his calls and entreaties to them to come, by his patience in waiting for them. He also draws them by their own consciences, which warn them of their sinne, and bear witness against it. More than all, he draws them by his Spirit." 3

In "The Saints Dignitie and Dutie" we read :"Christ gave himself to incarnation that he might be the ransom of the guilty. He suffered the wrath of God. $\mathrm{He}$ made a covenant with the Father, and $\mathrm{He}$ gave a perfect price, for the full payment of whatever is due to God for all those for whom He paid it."

1 The Soul's Vocation, 85.

2 Ibid., 160.

3 The Unbelievers Preparing for Christ, 44. 
Without further quotation, it is but just to say that Hooker sets forth the truth with great spiritual discrimination, great tenderness, and fidelity, and with a sweet reasonableness, which must have commended the Gospel to the people to whom the sermons contained in these volumes were preached.

\section{VIII.}

WE pass over half a century, to the time of President Willard. There had been a decline in the religious spirit of the people during that period. The prevalent Calvinism was stated in Tarsher and more dogmatic forms. Willard's Body of Divinity was begun in the latter part of the seventeenth century. It was the earliest folio on theology published in this country, and the largest book that had been published on any subject. ${ }^{1}$ It is in the form of lectures on the Shorter Catechism. It is valuable as a statement, by an able man, of the theological system which had prevailed for half a century before President Edwards set forth his Improvements in theology.

President IVillard expounded very clearly the external and internal evidence of the divine authority of the Bible. He taught the doctrine of

1 A Compleat Body of Divinity, by the Reverend and Learned Samuel Willard, late Pastor of the South Church in Boston, and Vice-President of Harvard College. 9I4 pages. Boston, I 726. 
verbal inspiration. The justice of God, he says, is His "inclination to render to all their due according to rule." 1 The benignity of God is "God willing bountifully to bestow the good things of this life upon sinners." " "Election is an act of grace. Redemption is an act of pure grace." Election is absolute, not hypothetical. The subjects of election are a definite number of men. "There are some men to whom God doth not afford the means and offices of Salvation, and they must needs perish." "Adam stood not as a private, but a public person. He was the representative, and the common stock of all Adam the Root mankind. All men were in him. If of the Race.

they were in him, and sinned in him, how can they be other than sinners? Adam sinned and all sinned in him." 3

"God is under no obligation to redeem men before His good pleasure." 4 "God's love of certain persons is not the cause of their election, nor is His hatred of others the cause of their reprobation." The last end of God's election is the manifestation and exaltation of the glory of His grace." " Reprobation is the predestination of a definite number of men for the manifestation of the glory of God's revenging justice in them." ${ }^{5}$ But "reprobation doth not take away the liberty

1 Body of Divinity, 75.

3 Ibid., I96-I97.

4 Ibid., 251.

2 Ibid., 84 .

5 Ibid., 26z-264. 
of the creature. God made no man on purpose to damn him."

He gives abundant space to the subject of Redemption. The humanity of Christ, he says,

Christ the Redeemer of nature." "The body of Christ had its "was a compleat undivided human natural origin from his mother." 1 The satisfaction by which Christ made reconciliation was given to the justice of God. He suffered the penalty for our sin. Christ died for the elect. "The covenant of redemption must last as long as there are any of God's elect to be born." "Christ died for a select company that was known to him, by name, from eternity." 2

"In his natural state, no man hath any seed of faith in him. His only capacity is a capacity to receive faith." "The cause of effectual calling is Inability. the everlasting love of God." The Spirit of God deals with the understanding and the will. He changes the will. The ability is from God. $\mathrm{W}^{\top} \mathrm{e}$ are persuaded and enabled to embrace Christ. The terms are presented, and the sinner is made willing. ${ }^{3}$ "There is a miserable impotency and malignity of will with respect to holy choices." The will remains a will, however. It has not lost its natural power. It cannot be forced. But a divine change is

1 Body of Divinity, 293-298.

8 Ibid., 428-436.

2 Ibid., 33I-3S3. 
necessary. The new principle of saving grace in the will and the affections is from God. "We are passive in conversion," and yet "there is an active as well as a passive conversion." "The man is dead. When the Spirit has given him life, then he is active in conversion." "Justification is immutable: therefore a justified person can never again come under a Law-guilt." "In sanctification there is a new power or ability put into the man." "A natural man can contribute nothing to his own conversion." 1

These quotations are perhaps enough to give a correct impression of this theology of the later Puritan age. The difference between this and the teachings of the earlier divines like Hooker and Norton is that President Willard places the emphasis upon the divine work in our salvation, so as to leave little room for the use of motives addressed to free and responsible beings, while Hooker and Norton are chiefly concerned to develop a sense of responsibility and of obligation. Theirs was a theology that could be preached.

\section{IX.}

THE theological views of our forefathers were influenced by their experiences in their new homes, quite as much as by the writings of their divines.

1 Body of Divinity, 449-505. 
If some of their opinions were severe, there was, after all, a fountain of gentleness and kindness in the heart of the typical Puritan.

One of the remarkable episodes in New England history relates to the Half-Way Covenant, which was approved by the Synod of 1662 , and which was in use for more than a hundred years. The Puritans seem to have adopted this, partly on account of their interest in their chilchen and grandchildren, who were growing up in the Colonies which they had planted in the wilderness. It was the easier for them to make this departure from the method of the first generation of Colonists, because the Puritans were never rigid Separatists. There was a good deal of truth in the remark of Roger Williams, that the "Churches of the Bay Colony were unseparated Churches." Although they followed the pattern of the Church The Half-Way Covenant. in Plymouth in the organization of their Churches, they still regarded the Church of England as their "Dear Mother;" and they had not forgotten its methods of baptism, and confirmation, and hereditary membership.

The early Puritans had made it a cardinal doctrine that none should be members of the Church except those who gave evidence that they had been regenerated by the Holy Spirit. They belicved that the corruptions of the Church of England were due to the easy terms on which 
persons had been admitted to the Lord's Table. They attempted to limit the membership in their new churches to those who were able to relate an experience of a work of grace in their souls. And yet they desired, in some way, to bring their infant children into some connection with the Church. "We find in Scripture," they said, "that the Lord is very tender of His grace, that He deliginteth to manifest and magnifie the riches of it, and that $\mathrm{He}$ cannot endure any straining or eclipsing thereof, which is both dishonorable unto God, and injurious unto men. And in special, He is large in the Grace of His Covenant, which He maketh with His visible Church and people, and tender of having the same straitned. Hence, when $\mathrm{He}$ takes any into Corenant with Himself, He will not only be their God, but the God of their seed after them in their generations. . . Hence, we dare not, with the Anti-predobaptist, exclude the infant children of the faithful from the covenant, or from membership in the visible church, and consequently, not from Baptism, the seal thereof." 1

And so they held, that the children of believers are included with their parents, and are entitled to all church privileges of which infants are capable. Among these privileges was baptism. ${ }^{2}$

1 Preface to the Result of the Synod of I662, Walker's Creeds and Platforms, 303. See also Mather's Magnalia, vol, ii. 23 s.

2 Mather on Church Government, 2I-22. 
They baptized their children, because these children were already members of the Church, by reason of the covenant into which their parents had entered. The older divines - Cotton, Davenport, Hooker, and Richard Mather - held, in the earlier years, that none but children of "visible saints" should be baptized. But these baptized children constituted a peculiar class in the Puritan churches. They were members, but not in full Communion. Their membership brought to them certain blessings of the covenant. They were hereditary members, and so under the watch and care of the Church. But they were not permitted to come to the Lord's Table, or to vote in the meetings of the Church until they should profess their assent to the doctrines of the Church, and accept its covenant, and give satisfactory evidence that they were born of the Spirit.

Unfortunately, as we shall presently see, the number of those in the Puritan churches who were in full communion was not large. For some reason, the means of grace were not as fruitful as had been expected. So that, in the second and third generations, there was a large number of parents, who were not in "full communion" with the churches. Most of these parents were accounted as members of the churches, because they had been baptized; but they were not communicants. Should they be permitted to present 
their children for baptism, on the strength of their half-way membership? According to the earlier practice they were not permitted to do so. But it was found that this practice was leaving the majority of the children without baptism.

This matter was earnestly debated in Massachusetts and Connecticut for many years. The tide was turning, and some of the older ministers began to relax the strictness of their views. In I656, the General Court of Massachusetts summoned a council of ministers, who were designated by name, to meet, with such others as any of the "Confederated Colonies" should send, to clear up the question. The Council met in ${ }_{1} 6_{57}$, in Boston, and decided that all members of the Church had the right to present their children for baptism, though some of them had not the right to come to the Lord's Table.

This decision of the Council, or Assembly, was not accepted as decisive. Some of the leading men, like President Chauncy in Massachusetts, and Mr. Davenport in Connecticut, objected to it, as an abandonment of the principle of a converted Church membership. Finally, the General Court of Massachusetts called a proper Synod, composed of all the ministers and the representatives of all the churches in the Colony.

The Synod of 1662 .

This Synod met in Boston, the second Tuesday in March, I662. It contained about serenty 
members, one-third of them ministers. The Q principal question given to them was this: Who are the Subjects of Baptism?

After some weeks of consideration and debate, the Synod, by a vote of seven to one, decided in favor of the Half-Way Covenant. They held that parents who had been baptized in infancy, who were not scandalous in life, and who had solemnly owned the covenant before the Church, wherein they gave themselves and their children to the Lord, might present their children for baptism. This was called the Half-Way Covenant, because these parents were in covenant with the Church, not as "visible saints," who had been renewed by the Holy Spirit, and who were prepared to come to the Lord's Table, but only as baptized persons who had an intellectual belief in the truth, and who were living moral lives. These parents were in the Church on account of the faith of their parents, at one remove ; and their children were in the Church on account of the faith of their grandparents, at two removes.

The decision of the Synod added intensity to the discussions among the people. A multitude

Dissent from the Views of the Synod. of pamphlets followed, in which one can still read the close and earnest discussions of two hundred and thirty years ago. There were Synodists and Anti-synodists. A decided majority of the ministers favored the Half- 
Way Covenant. A large number of the people never accepted it. Some of the most learned and able ministers warned the people that the new method would open the doors of the churches to the unworthy, and that it would tend to throw into the shade the rork of the Spirit in regeneration. The need of a change of heart would not be felt by those who had not only been admitted to membership in the Church, but who had participated in some of its most sacred rites. ${ }^{1}$

President Chauncy, of Harvard, and John Davenport, of New Haven, led the opposition to the new system, while Wilson and Norton and Mather, among the older ministers, and a large number of the younger ministers were its earnest advocates. Cotton Mather tells us that although the pastors generally favored it, yet in many of the churches a number of the brethren were so decided in their opposition that it was not practicable to follow the recommendations of the Synod. The First Church in Boston, as soon as there was a vacancy in the pastorate, called Mr. Davenport to be their minister on account of his opposition to the Half-Way Covenant. This call led to a division of the church, and the formation of what is now the Old South Church. ${ }^{2}$ For some years these two churches did not commune

1 Mather's Magnalia, vol. ii. 259-266.

2 Ibid., 266. 
with each other. But those who accepted the new methods were the more numerous party, and the tendency was for those who had been opposed to them to fall in with the common practice. A few churches, however, never accepted the laxer method.

As time went on, the Half-Way Covenant was itself modified. In the beginning, only those who had themselves received baptism, were permitted to own the covenant, and to present their children for baptism. In the time of Cotton Mather, any one who was free from scandalous sins, and from open impiety, could be baptized. 1 "Owning the Covenant" was at first a very solemn profession of a purpose to lead a Christian life. Before the close of the century, however, owning the corenant, and presenting the children for baptism, had become mere forms, which were supposed to have a certain efficacy of their own. In fact, the rites and sacraments of the Puritan churches came to be regarded in the earlier years of the eighteenth century as means of salvation. So the grand-children of the early Puritans approached very nearly the practices which their forefathers had condemned in the Church of England.

As the seventeenth century closed, there ras a Tow type of piety in the churches. With this came, on the one side, a hardening of the

1 Mather's Ratio Disciplinæ, So. 
doctrines which were preached in the pulpits, and on the other side, a departure from those doctrines, and the adoption of what was then called Arminianism. The necessity of a work of the Spirit to renew and sanctify the heart was no longer insisted on. Revivals of religion were few. There was a tendency to preach morality, instead of to insist upon a really spiritual experience. The venerable Stoddard of Northampton published a sermon, in I 707, in which he maintained that "the Lord's Supper is a converting ordinance, and that sanctification is not a necessary qualification to partaling of the Lord's Supper." 1 These views were accepted in many churches. Discipline was much neglected, and immorality was tolerated. The difference between the Church and the world was fast passing away. It was not until the Great Awakening, in the time of Edwards, and of Whitefield, that the churches came back to the earlier views in regard to the qualifications for membership in the Church. There were a number of churches that refused to hear Whitefield, or to enter into the new religious movement. These churches held to a dry and lifeless orthodoxy, and placed great reliance upon forms and religious rites. New England Unitarianism, which was developed toward the close of the eighteenth century, and

1 'The Great Awakening, Joseph Tracy, 4. 
the beginning of the nineteenth, was the result of a departure from the older religious views, which began in the times of the Half-Way Covenant.

The preaching which led to the great revival gave special emphasis to the work of the Holy Spirit in the change which is called conversion. It led to a sharp discrimination between the Church and the world. The Half-Way Covenant was gradually laid aside, and with it the theory of hereditary Church membership. The new method of stating the doctrines of grace, which was set forth by President Edwards, led to a new style of preaching, which gave prominence to the freedom and responsibility of man. This method of preaching prepared the way for the great revivals of religion which marked the close of the last century and the earlier years of the present century. From those revivals have sprung the great missionary movements of the nineteenth century, and the new and more enterprising spirit in the churches of all denominations, in our times.

\section{X.}

Tre discussion of the influence of the Synod of 1662 has led us far beyond the period to which

1 Edwards' Qualifications for Full Communion. Mather's Magnalia, vol. ii. 279. Walker's Creeds and Platforms, 2S0-290. Tracy's Great Awakening, I-40. 
that Synod belonged. But there was another Synod which had an influence upon the religious views of the fathers of New England, which should have a place in this section.

This was the Reforming Synod of 1679 , which met in Boston, September Ioth, of that year, at the call of the General Court. It was made up of the Elders and Messengers of the churches of the Colony. It was called to consider two questions: first, "What are the evils that have provoked the Lord to bring His judgments upon New England? second, What is to be done that so these evils may be reformed?" The people had been suffering from the great Indian wars, and from extensive conflagrations, from shipwrecks, and from the pestilence. They believed that these disasters had come in God's providence, in consequence of their sins; and they set themselves to inquire, with fasting and prayer, for the causes of these great disasters. After mature deliberation the Synod prepared a statement of the The Reforming evils that were common in the Colony, Synod of I 6 \% 9 . and presented it to the General Court. This careful official document is preserved in Mather's Magnalia, and in other works; and it casts a flood of light upon the religious condition of Massachusetts at the end of the first half-century. I quote only the leading statements, each of 
which is supported, in the original paper, by a number of particulars. They say: ${ }^{1}$ " There has been a great and visible decay of the power of Godliness amongst many Professors in these churches: communion with God, in His ways of worship, especially in secret, is much neglected;" the sins of "pride," "of contention," and of "extravagance," abound; "servants and the poorer sort of people are guilty in this matter," they "goe above their estates and degrees;" "church fellowship is greatly neglected; the rising generation are not mindful of that which their Baptism doth engage them unto;" "Profanity abounds;" "there is much irreverent behavior in the solemn worship of God." There is also, "much Sabbath breaking;" "traveling on the Lord's day is common." "Family worship is much neglected;" "the Scriptures are not daily read, that so the word of Christ might dwell richly with them." "Law-suits are common, brother going to law with brother." "There is much intemperance. That shameful iniquity of sinfull drinking is become too general a Provocation, Dayes of Training, and other publick Solemnityes have been much abused in this respect." "Indians have been debauched, by those who call themselves. Christians, who have put

1 Mather's Magnalia, Hartford ed. I820, vol. ii. 273. Williston Walker's Creeds and Platforms, 426-436. 
their bottles to them and made them drunk also." "Instead of converting the Heathen" these people have "taught them wickedness which before they were not guilty of." "Church members frequent publick Houses," and "there misspend precious time, unto the dishonor of the Gospel." "These are hainous breaches of the Seventh Commandment. Temptations thereto are become too common." There is "unlawful gaming," "and an abundance of Idleness," there are "mixed Dancings;" "immodest apparel is put on;" "there is a want of truth amongst men: promise breaking is a common sin, for which New England doth stand ill abroad in the world." There is also an "Inordinate affection to the world." "Farms and merchandisings have been preferred before the things of God." "Religion is made subordinate unto worldly interests." "Some traders sell their goods at excessive Rates." Men are "under the prevailing power of a worldly spirit." "There hath been much opposition to the work of Reformation." "Sin and sinners have many Advocates." "A public spirit is greatly wanting in the most of men." "All seek their own; not the things of Jesus Christ." "Hence, schools of learning, and other publick concerns are in a languishing state," "Christ is not prized and embraced in all his offices and ordinances as ought to be." Last of 
all, "there is great unfruitfulness under the means of grace."

After these statements of the sins which were most common in New England at that time, the Synod made an earnest appeal to the good people to seek to bring about a reformation. They urged those in official positions, first of all to take the lead in a reform of manners. They advised that none be admitted to the "Lord's Supper without making a personal and publick profession of their Faith and Repentance, either orally, or in some other way, - to the satisfaction of the Church." They also urged the duty of attending to discipline in the churches; of seeking to "provide a full supply of officers in the churches;" of providing "for the maintenance of ministers;" of "due care and faithfulness with respect unto the establishment and execution of wholesome laws; especially laws to regulate Publick Houses, - to regulate the sale of strong drink; and to punish vice and crime."

They also recommended solemn and explicit renewal of the Covenant in the churches, the confession of sin, and a turning unto the ways of the Lord. The people should "cry mightily unto God, that $\mathrm{He}$ would be pleased to rain down Righteousness" upon them.

This appeal of the Synod was heartily seconded by the General Court. The laws against intem- 
perance, and Sabbath breaking, and various forms of vice were more strictly enforced. The churches entered into the work of reformation with great earnestness. Days of fasting and prayer were appointed; there was a solemn renewing of the covenant in many places; the ministers preached frequently, not only on the Lord's-days, but on week days; and, Cotton Mather tells us: "Many thousands will testifie that they never saw the special presence of God more notably discovered, than in the solemnities of those opportunities." 1

\section{XI.}

THE same Synod met again, by adjournment, May I 2, I6So, to propose a Confession of Faith. The Boston Synod of ${ }_{1648}$ had expressed a hearty assent to the Westmin- Addotion of the ster Confession, "for the substance thereof." But the Congregationalists of England determined to have a Confession of their own. Accordingly, a council, or Synod, met at the Savoy, in London, September 29, I658, composed of representatives of one hundred and twenty churches. The number of members was about two hundred. The session lasted two weeks. The Synod amended the Confession of the Westminster Assembly in a number of respects, with-

1 Cotton Mather, Magnalia, vol. ii. $2 \$_{3}$, edition of $\mathrm{I} \$ 20$. 
out changing, however, its strong Calvinistic statements; and then adopted the amended Confession unanimously, October i 2, I658. The phraseology was improved in a number of sections. A new chapter was added concerning "the Gospel, and the extent of the Grace thereof," which is intensely Calvinistic. In chapter twenty-four, they asserted the principle of toleration in minor matters, for those who do not disturb others in their way of worship. They omitted such parts of the older Confession as set forth the Presbyterian form of Church government; and they added thirty sections relating to Church order, according to the Congregational way.

When the Boston Synod came together, in I680, for its second session, it proceeded at once to act upon the report of a committee, chosen at its first session, to draw up a Confession of Faith. This committee recommended the adoption of the Savoy Confession, with slight and unimportant amendments. The Synod went carefully through the Confession, adopted the amendments proposed, and then adopted the Confession. The General Court, the next month, approved of this action of the Synod, and ordered that the Confession, with the Platform of 1648 , "be printed for the benefit of these churches in present, and after times." 1 This Confession continued to be the standard of

1 Mass. Records, vol. v. 287. 
the Congregational churches for almost two hundred years. The National Council of $1865-$ which represented not merely the churches of the Colony of Massachusetts, but the Congregational churches of the United States - declared that it embodied substantially the faith of those churches. ${ }^{1} \quad$ There have been a number of periods since 1680 , when the Congregational churches have taken up certain improvements upon the older statements of Calvinism, and the New England theology of to-day is much broader than that of the older Confessions; and yet, the Savoy Confession is the only extended and elaborate Confession of Faith which they have ever adopted. The Connecticut Synod, which met at Saybrook, September 9, I 708, also adopted the Saroy Confession, at the same time that they adopted the Saybrook Platform.

\section{XII.}

In closing this statement of the religious opinions of the fathers of New England, it is important to point out the influence of this system of religious teaching upon the people.

These doctrines of the older Calvinism were practically the only doctrines that were preached in New England for about a hundred years.

1 National Congregational Council, $1865,36 \mathrm{r}$. 
They had full sway among a people who were isolated from the great currents of thought in the larger world. In the results of that teaching, we Results of the have an indication of what that type Preaching of
the older of theology is likely to effect. In calvinism. no other part of the world, except possibly in Scotland, has High Calvinism been given so clear a field in which to develop its full influence.

It should be said, in the first place, that the religious teachings of the early preachers of New England did develop a remarkable type of religious character. We have abundant evidence to show what that type was. There was a high ethical standard, for one thing. The religious I men of that time were honest men. Their lives were pure. They brought up their children to fear God, and keep His commandments. They were also devout men. They magnified, above all other things, their personal relations with a personal God, the Father of our Lord Jesus Christ. They believed that they were the elect of God, the objects of His peculiar care, and destined to an eternal inheritance in heaven. So they lived as pilgrims and strangers on the earth. Their lives were directed by the Providence of God, and they were working out His great plans. No other people have had more reverence for the Bible, or the Sabbath, or the Church, with its ordinances. 
They were guided by the highest motives. They had the world under their feet. Their training made them good soldiers of Jesus Christ. They had the spirit of the Scottish Covenanters.

Their theological views tended to make them the defenders of liberty. They laid the foundations of the Republic. Their churches were democratic. So were their towns. So were the Colonies, as far as the casulvinistic people were permitted to frame their Training. government. And when George the Third, far on in the eighteenth century, attempted to deprive the English Colonists of their rights as Englishmen, the descendants of these Calvinistic Puritans took the lead in the Revolution which made us a free nation.

Our fathers, also, transmitted to their descendants a vigorous type of manhood, and that type has been perpetuated, among the widely scattered sons of the Puritans, for two centuries and a half. They have been men of convictions, - with the courage of their convictions, - the defenders of liberty, and the champions of the oppressed. It is not too much to claim that this Calvinistic training - like iron in the blood - gave tone and quality to the New England character. 


\section{XIII.}

So much may be justly claimed for the results of the religious training in the early times in New England. But there were other results of that training which were not so desirable. That which religion gained in intensity in those times, it lost in extcnsion. The religious teaching and discipline, which made a small number eminent in piety, left the largest part of the people outside the churches. The first generation of Colonists were a selected class. God had sifted them out from the mass of their countrymen, that they might be the seed for a new Christian nation. They were men of eminent piety. They were devout men. They walked humbly before God. small rumber Religious ideas and religious motives of Members in
the Puritan guided their plans of life. But it was churches. not so with the second generation. The majority of the sons of the Puritans never became communicants in their churches. Lechford says, that at the time of his visit, in I64I, only a quarter of the people were members of the churches. ${ }^{1}$ As none could become voters in the Colony of Massachusetts who were not communicants, it was a subject of complaint, at all periods of its history, that only a minority of the male

1 Lechford's Plain Dealing, 59. 
adults could have any share in the government. Mr. Palfrey states, as the result of careful investigation, that, in 1670 , the number of freemen in Massachusetts was between ten and twelve hundred. That was equal to a quarter or a fifth part of the adult males in the Colony. ${ }^{1}$ It is true that some male members of the churches did not become freemen; but the number of such was never large. So that it appears to be true that only about a quarter of the grown men in the Colony were communicants in the churches. This fact was frequently referred to in the political discussions of those times. This large number of disfranchised people complained of the injustice that was done Small Number plained of the injustice that was done of Members in them. From time to time concessions were made to their demands. ${ }^{2}$ These facts show very plainly that a large proportion of grown people were outside the churches. These noncommunicants were the children of the Puritans. Very few came into the Colony from Europe

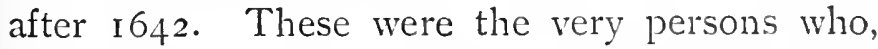
under favorable conditions, would have been most likely to come into the churches. IVhy was it that the children of the Puritans were not pre-nky pared to become members of the churches? There was something pathetic in the complaints

1 Palfrey's New England, vol. iii. 4I; vol. ii. S, note.

2 Pages I68-1 70 of this volume. 
which the fathers were continually making of "the great unfruitfulness under the means of grace." TVe have seen that it was the consciousness of this "unfruitfulness" that led to the Half-Way Covenant. They hoped to prepare their sons and daughters for "full communion," by admitting them to some of the privileges of the Church. But this expedient failed. Those who came into the churches were not benefited, unless there had been a work of God's Spirit in their souls.

If we compare the "fruitfulness under the means of grace," in the first century of our history, with that in the present century, we shall find that we have at present one in five of the people of the United States, a communicant in some one of the Protestant churches. This is, not one in five of the adults, but one in five of all who are counted when the census is taken; persons of all ages, from infancy upwards, including a great many millions of people of foreign birth and training, and with alien languages. But the Puritans had a population of pure English blood, and of Puritan training.

\section{XIV.}

Another very significant fact relating to the Puritan churches in the first century is this: they did not succeed in maintaining a vigorous 
spiritual life among Christians. There were times when the religious spirit rose very high. But there were also times of long-continued declension, when it seemed to good men that "the glory was departing from New England." The election sermons preached in Religious Massachusetts in 1668,1669 , and 1670 , Declension in all speak of such a declension at the churches time of the Reforming Synod. ${ }^{1}$ The statement of Thomas Prince is that "a little after 1660 there began to appear a Decay: And this increased to 1670, when it grew very visible and threatening, and was generally complained of and bewailed bitterly by the Pious among them: And yet much more to i6So, when but few of the first generation remained." ${ }^{2}$ These statements are confirmed by the Result of the Synod of 1679 . The earnest religious services which followed the Reforming Synod were of use in checking the downward tendency, and yet, the religious life in New England between I680 and I735 was very far below the expectations of the fathers. Revivals of religion were few. Dissensions arose in the churches which led, in some instances, to divisions. The fanaticism and cruelty which attended the proceedings relating to witchcraft were partly

1 Election Sermons, by Mr. Stoughton, I668, Mr. Thomas Walley, I669. Mr. Samuel Danforth, 1670.

${ }^{2}$ Christian History of New England, vol. i. 94, Boston, I7+3. 
the result of the decay in the religious life of New England. There was a movement, toward the end of the sixteenth century, in Massachusetts, to strengthen the system of Church government, in the hope that by this means the churches might be protected from false doctrines, and prepared to enforce Church discipline. This movement, which failed in Massachusetts, was successful in Connecticut, and led to the adoption of the Saybrook Platform in $\mathrm{I} 7 \mathrm{OS}$.

Still the process of declension went on. The statements which are made in the works of President Edwards, and in the journals of Mr. Whitefield, and the writings of others who had a leading part in the Great Awakening show that the condition of the churches was even worse than it had been at the time of the Reforming Synod. ${ }^{1}$

It appears further, from the writings of the younger Edwards, that the High Calvinism which was preached here so long, finally lost its hold upon the people, in consequence of the spread of what was called in those times Arminianism. There is abundant evidence that cluring the first third of the eighteenth century, a large number of the pastors became Arminians. Dr. Edwards says, "The Calvinists were nearly driven out of the field by the Arminians, Pelagians, and Socin-

1 Dwight's Life of Edwards, vol. i. I 20. Journals of Whitefield. Life and Times of Whitefield. Tracy's Great Awakening. 
ians. The Calvinists appealed to Scripture," he adds, "in support of their peculiar tenets, but the sense in which they interpreted the sacred writings was inconsistent with human liberty, moral agency, accountableness, praise, and blame. It was inconsistent with all command and exhortation, with all reward and punishment. The Calvinists themselves began

Testimony of the Younger Edwards.

to be ashamed of their own cause, and to give it up, so far at least, as it relates to liberty and necessity." 1

"But Mr. Edwards," he continues, "put an end to this seeming triumph of theirs." He points out the "Improvements in Theology" which his father had introduced, such as "the difference between natural and moral necessity, and inability;" the nature of true holiness; the origin of evil; the doctrine of Atonement; of imputation; and of regeneration. President Edwards "proved that the Atonement does not consist in the payment of a debt," but that the suffering of Christ establishes "the authority of the divine law," and "supports the divine government," so that " God without the prostration of $\mathrm{His}$ authority and government can pardon and save those who believe."

1 Works of Dr. Jonathan Edwards, vol. i. 480-48r. See also the statements in The Case of Robert Breck in this volume, 335-36o. 


\section{XV.}

Ir is quite possible that some of these strong statements need to be modified. The estimate of the older theology which Dr. Edwards sets forth was doubtless influenced by his own decided leanings toward the new divinity which the elder Edwards had done so much to recommend. But after making all necessary allowances for the personal element in his statements, the evidence is The New Eng- conclusive that the extreme High Calland Theology. vinism of the earlier Puritan divines had proved insufficient to meet the needs of the later generations of New England people, and that, too, under the most favorable conditions of which we can readily conceive. It failed to do justice to the great truths concerning the Love of God, in the Work of Redemption, and in the free offers of salvation. It also failed to present the claims of God so as to develop the sense of responsibility, which commends the call of God to every man's conscience.

The elder Edwards - our greatest theologian thus far - was enabled to relieve that system of some of its difficulties, so as to give to Consistent Calvinism a new lease of life. Out of these Improvements in Theology there grew a new method of preaching. The great revivals of 1730 
to $\mathrm{I} 750$ were the results of this new method of presenting the truth to men. Since the Edwardean period, there has been in the Puritan churches of New England a modified Calvinism, which has been called the New England Theology. The successors of Edwards - Hopkins, Smalley, the younger Edwards, Emmons, and the others have followed out his principles along two divergent lines. So that, whatever else may be said of those theological views which have prevailed in New England for the last century and a half, it cannot be said that they have been entirely borrowed from others, or that they have been received without original and thorough examination. It is safe to predict that the theology of the future, among the Puritan churches of New England, will be developed along the lines which were marked out by President Edwards. 



\section{VII.}

The Case of Reverend Robert Breck, of springfield. 



\section{The Case of Reverend Robert Breck, of Springfield.}

THE beginning of the second century in the New England Colonies was a period of transition. Many of the best influences of the earlier period were still vigorous. The country had lost the appearance of a newly settled region. The population was already numerous; the people were living in comfortable houses; their farms were well-cultivated and productive. The people had lost something of the provincial character. They were already open to the influences from the larger world beyond the sea. Some of the customs of the earlier years had been the Perrod of dropped. The meeting-houses were Transition. larger and more comfortable. There had been a great improvement in the style of sacred music. There were choirs in many of the churches. The practice of reading the Scriptures without an exposition had become common. Marriages and funerals were conducted by the ministers much as they are now. 
The Half-Way Covenant had brought many changes into the churches. Those who desired to become communicants were not scrutinized as closely as they had been in the earlier times. Yale College had been founded ; and it was already an important institution of learning in the new country. The churches of Connecticut had adopted the stronger polity of the Saybrook Platform. They were more conservative than those of Massachusetts. There had been a departure, more or less general, from the older theology. There was a conservative wing, and a liberal wing, among the ministers. The term Arminian was applied, as a term of reproach, to those who were beginning to question the views of the older Calvinists.

The best way to study this period is to investigate some one of the controversies of the time, important enough to have connections with a large number of people, from different localities, and of different callings in life. Such a controversy was the one which arose in Springfield, Massachusetts, in I734, and continued for two years, in respect to the settlement of Robert Breck as pastor of the church in that town; an event which had a certain importance, in its time, for the people of Springfield, but which interests us mainly on account of the light it casts upon the way of life of the people a century and a half ago. 


\section{I.}

THE town of Springfield was then one hundred years old. There were about a thousand people living within the present limits of that The Town of city. Mr. Breck was the fourth pastor Springfield. of the church. The average length of the pastorate had been thirty years. The number of members of the church was sixty-seven. The valley of the Connecticut was already full of thriving towns and villages. We read in the pamphlets of that time of Long- $\begin{gathered}\text { Prosperity of } \\ \text { the Connecticut }\end{gathered}$ meadow, and Westfield, and Hadley, valley. Northampton, Hatfield, and Deerfield, among other places in the vicinity. The Hampshire Association of Ministers was a vigorous organization, made up of thirteen pastors, among whom were Jonathan Edwards, of Northampton, Isaac Chauncy, of Hadley, William Williams, of Hatfield, Stephen Williams, of Longmeadow, Samuel Hopkins, of West Springfield, and Ebenezer Devotion, of Suffield. This Association, though organized for the mutual improvement of its members, like similar bodies in our own time, was accused of seeking to control the action of the churches in the selection of their pastors. It was alleged that some of these pastors were Presby-

1 Judge Morris' Historical Address. 
terians, and that they took it for granted that an Association had powers like those of a Presbytery. Their theological views were, for the most part, those of the earlier Puritans, which are moderately stated in the Westminster Confession of Faith. It was before the time of the "Improvements in theology" set forth by President Edwards. But even then, as we shall see, there was a difference in theological opinion among the pastors, and a still greater difference in their views of Christian liberty. For the most part they were devoted to their religious work. The years 1734 and 1735 were the years of the Great Awakening at Northampton; and Mr. Edwards was too fully absorbed in his work at home to enter very fully into the affairs of the church in Springfield.

\section{II.}

THE ministers and churches of Massachusetts at that time were profoundly affected by the conchurch and nection of the Church with the state. State.

The laws of the Colony of Massachusetts Bay had limited even the right of suffrage to members of the church. The charter of the Province of Massachusetts, which was granted by William and Mary, in 1691, extended the suffrage to all male freeholders who possessed an estate worth two pounds a year. This provision of the 
charter opened the way for giving to those who were not communicants a voice in the selection of their ministers, and in the direction of the pecuniary interests of the parish. All this tended to liberalize the spirit of legislation. The General Court of the Province never enacted a law for the punishment of heresy by fine and banishment, such as that under which William Pyuchon had been summoned to appear before the General Court, in 1650, to answer for his book entitled "The Meritorious Price of our Redemption." 1

Still, the legislation of the provincial period of our history was designed to bring the Church under the fostering care and protection of the state. The basis of this legislation was a law passed in 1692 , at the second session of the General Court, under the provincial charter, for the settlement and support of ministers. ${ }^{2}$ It requires the inhabitants of each town to be constantly provided with "an able, learned, and orthodox minister, or ministers, of good conversation, to dispense the word of God to them." The minister was to be chosen by the church, "according to the directions given in the Word of God." The inhabitants of the town or precinct "who usually attend on the public worship of God," were to be

1 See page 203 of this volume.

2 These laws may be found in the Province Laws, vol. i. 62, I02, 2 I6, 506, 597 ; and vol. ii. 58 ; vol. iii. 288 . 
called together to accept or reject the candidate whom the church had chosen. If they accepted him, he became the legal minister of the town or precinct. If they rejected him, the church might still refer the matter to a council of neighboring churches, and if the council approved the choice of the church, the minister, accepting the call, ${ }^{1}$ and duly installed, became the legal pastor, and was entitled to his salary. The amount both of the "settlement" and of the "maintenance" of the minister was fixed by a contract before his introduction to his office; and the people were required to pay toward his settlement and maintenance, "each man his several proportion thereof." The Court of General Sessions of the county was required to see that the contract was fulfilled. If any town or precinct should neglect to provide itself with a suitable minister, the Court of Quarter Sessions was required to " make order upon them speedily to provide themselves with a minister." If this order was disregarded, it was the duty of the court to procure and settle a minister, and order the charge of such minister's settlement and maintenance to be levied on the inhabitants of such town. At a later time, it was made the duty of the General Court itself, on

1 The first law gave the choice to the people of the town. This was amended at the next session so as to give the church the right to lead in the choice. 
receiving notice from the court of any county that a town or precinct was destitute of a minister, to provide and send to every such town or precinct an able, learned, and orthodox minister, of good conversation, and to provide for his support by adding to the taxes of such town or precinct so much as they should judge sufficient for this end.

Thcse laws assumed a definite method of procedure on the part of churches and congregations, such as is marked out in the Cambridge Platform. This Platform had a quasi-legal authority, having been commended to the churches by the General Court, and it was constantly appealed to as the standard in the discussions of those days.

Thus the churches of the olden time were accustomed to depend on the authority of the state for raising the money to support public worship. In the course of time, they learned to follow legal forms and precedents, and to transact much of their most important business in a legal spirit and environment. There would sometimes be a doubt whether a council called to settle a minister had been legally called, and whether its proceedings were regular and valid; whether a minister had been "duly settled according to law ;" whether a minister was " orthodox, able, learned, and of good conversation," within the meaning of the law; and whether he continued to possess all these excellent qualities. On the decision of these 
questions would depend his right to his salary, and also the right of the town, or parish, to assess a tax for his support. Sometimes the question would be raised whether a town which was supporting a minister had such a minister that it was not liable to be presented by the grand jury, and prosecuted as a destitute town. These discussions and litigations were among the most characteristic things relating to the life and manners of our fathers.

\section{III.}

Robert Breck, of Springfield, was the son of Rev. Robert Breck, of Marlboro', of whom the "Boston News-Letter" said: "He was an able minister, a man of great learning in the original languages of the Bible, and in philosophy, and also a man of great courage and prudence." His grandfather was Captain John Breck, "a very ingenious and worthy man." His great-grandfather was Edward Breck, a man of wealth and influence in England, who came to this country in 1636 , and settled in Dorchester.

Robert Breck was born in Marlboro', Massachusetts, July 25, I7I3, and entered Harvard Robert Breck. College at the age of thirteen. His rank as a scholar is indicated by the fact that the President and Fellows awarded to him the honorary prize of thirty pounds as a 
"sober, diligent, and promising student, and candidate for the ministry." He was graduated with honor in 1730 . It has been stated that he studied theology with his father, but as the father died the year after his son was graduated, it is probable that he continued his studies without an instructor. He began to preach while he was very young, according to the custom of those times. He was hardly more than twenty when we find him preaching in Scotland, a parish in Windham County, Connecticut, and at various other places in that Colony. The young and untrained preacher was very free and bold in his utterances, and very early subjected himself to the charge of heresy, a charge which some of the pastors of the vicinity were disposed to press to his injury.

Some time in May, I734, the First Church in Springfield invited him to preach as a candidate for settlement. He came, and preached called to settle to the acceptance of the people, so that as Pastor. after about three months the church and parish gave him a call, and proposed terms of settlement. He had then just passed his twenty-first birthday.

Soon after he came to Springfield, there were reports passing from one to another that he was not sound in the faith. The people listened to his sermons, but failed to detect anything that 
savored of heresy. So far as the pamphlets ${ }^{1}$ which were published at the time, on both sides, give us information, it was not claimed that there was anything unsound in his religious teachings after he came to Springfield. The reports all came from Connecticut. A letter was received from a minister in that Colony, which stated that "Mr. Breck was not a suitable person to be employed in the ministry," and named Rev. Thomas Clap, of Windham, afterwards President of Yale College, and two others, as persons who were responsible for the charges. This letter was put into the hands of Mr. Breck, who went at once to Windham to confer with Mr. Clap in respect to the accusations. Mr. Clap was not chargesagainst satisfied with the result of the conferhim.

ence, and so wrote a long letter to the Hampshire Association of Ministers, in which he set forth the four charges against the young canclidate for the pastorate.

I. That he had denied that the passage in I John v. 7, concerning the "three that bear record in heaven," and also the passage in John viii., concerning the woman taken in adultery, were of divine inspiration.

1 Narrative of the Proceedings of those Ministers of Hampshire County that have disapproved the Settlement of Mr. Robert Breck, Boston, 1736 .

Answer to the Above, Boston, 1736 .

Letter to the Author of the Answer, Boston, I737. 
2. That he had also denied the necessity of Christ's satisfaction to divine justice for sin, and had said that God might, consistent with His justice, forgive sin without any satisfaction.

3. That he had preached that the heathen, who lived up to the light of nature, would be saved. Christ would be in some way revealed to them; or they would be saved in some other way.

4. That there was a general report that he had stolen books from the college library, while a student, and that he had been expelled from college for this offence; and further, that when Mr. Clap had informed him of these reports, he had denied them, a denial which was now known to be false.

In addition to all this, it was stated in other letters that Mr. Breck had said publicly, that "if the decrees of God were absolute, he saw no encouragement for men to try to do their duty, for let them do what they would, they could not alter their condition; and that we were not under obligation any further than we had power." On the ground of these statements, it was charged that he was an Arminian.

\section{IV.}

These charges were the basis of the opposition to the settlement of Mr. Breck. In reply to the charges, he claimed that it was unjust to use 
against him expressions which he might have made use of in his earliest sermons, at a time when his views were quite immature; that these expressions did not express his settled opinions; that some of them had never been used in his sermons, but only in oral discussion with pastors with whom he was discoursing, for the sake of clearing his own mind; and also, that some of these statements were not inconsistent with the Confession of Faith. He asked to be judged, not by these early sermons, but by the sermons he had preached in his present pulpit; and he repeatedly invited those who questioned his orthodoxy to satisfy themselves by an examination as to his views in theology.

In respect to the charge of taking books from the library, he admitted that there had been a technical offence, which gave some color to the charge, but claimed that the offence, such as it was, was the fault of a boy of thirteen, and that it was so trivial that the faculty did not make it a matter of formal discipline, and that his subsequent deportment had been so exemplary that they had selected him as the student most worthy to receive the honorary prize. Mr. Breck also stated that he had never denied that there had been some foundation for the story, but had only denied it in the exaggerated form in which it had been reported. These are the leading 
points in the case as it is presented in the pamphlets and in the manuscripts which have been preserved.

Mr. Breck was informed that these reports had excited a degree of prejudice against him among the ministers of the vicinity, and that Declines if he were to accept the call they might the call. refuse to ordain him. He was also informed that they had exerted more or less influence with some members of his congregation. He therefore decided to refer the matter again to the people. He knew that he had the confidence of a large majority of his congregation, and that some of the pastors of the vicinity were satisfied as to his integrity and his orthodoxy, so that there would be no serious difficulty in securing ordination. "If one council will not do it," he said, "another will." With these views, he stated, in his reply to the call, that while he was disposed, on some accounts, to accept their invitation, he did not think the provision for his temporal support was sufficient, and that he could not accept the call unless they should see the way clear to increase it. The people were not quite agreed in the matter, and did not think it expedient to increase the salary. So that Mr. Breck finally declined the call, and returned to his friends in Boston. 


\section{V.}

But the people were not satisfied. The records of the parish show that the majority believed that his settlement had been prevented by the intermeddling of "some persons of note who had sent writings to some of the ministers of this vicinity." The parish, therefore, appointed a committee, November Sth, to find out how much ground there was for the charges against Mr. Breck, and also to learn more definitely the views of the ministers. In response to their inquiries, six of the pastors, among whom we find the name of Jonathan Edwards, signed a paper, which reads as follows :-

"Upon consideration of the case of Mr. Robert Breck, represented to us in some letters from Windham and Norwich, we think it advisable that the people of Springfield do no further make their application to him."

The committee reported, and the people considered the advice. Six weeks later, the freeholders, and other inhabitants assembled according to law, voted "that application be made to the worthy Mr. Robert Breck to preach the word of God to us in this place, in order to a settlement." This vote was passed by a decisive majority, and a committee was chosen to proceed to Cambridge, make inves- 
tigations, ask advice, and act according to their best judgment. The result was that Mr. Breck returned to Springfield, and began to preach again. This open disregard of the advice of the ministers of the vicinity seems to have been unusual, and it had the effect to lead them to enter more directly into the case. A majority of them seem to have thought that it would be an infringement of their rights for the people to settle a minister within the county in opposition to their advice. The next stage in the business was the effort of the Association to investigate the charges against Mr. Breck. They entered into correspondence with various parties in Connecticut; and also induced Mr. Breck to write to Mr. Clap, and endeavor to make his peace with him. They invited Mr. Breck to attend the meeting of the Association, in April, I 735, and make such statement as he thought proper with reference to the charges. He seems to have accepted their proposals in good faith. He wrote a letter to Mr. Clap, in which he made such acknowledgments and concessions as he thought proper, but he failed to satisfy that gentleman. He also read to the Association a paper which was quite satisfactory to some of the pastors, but not to the majority. Six out of thirteen ministers now took his part, and remained his friends to the end. He next asked the Association to satisfy themselves as to 
his theological views by an oral examination. The majority declined to do this, on the ground that charges were already pending against him. At this stage of the business a committee from the First Parish appeared before the Association to inquire "what impediment, if any, there was to the settlement of Mr. Breck; and if such impediment existed, how it could be removed."

\section{VI.}

THis was designed to open the way for a formal examination of the charges of $\mathrm{Mr}$. Clap and others from Connecticut. Mr. Breck and his friends were prepared to welcome such an investigation; but they asked to be permitted to name one or two of the persons who were to pass upon the case. The Association appointed seven of their own members to hear the whole case, and to give their judgment. It was pointed out to them that several of these gentlemen had already prejudged the case, and expressed their opinion publicly. $\mathrm{Mr}$. Breck offered to go on with the investigation if one of the committee would retire, or if, that gentleman remaining, he might call in two unprejudiced persons from outside the county. These propositions were declined by the majority, and so the proposed investigation failed. 
At this stage of the business the First Church in Springfield, on the I 7 th of April, renewed their call to Mr. Breck, and one week later the call the parish voted to concur. It ap- Renewed. peared that a decided majority of the church and congregation were very earnest to secure the permanent settlement of the young preacher as their pastor. It remained to be seen whether the minority of the people, aided by the majority of the Association, would be able to prevent it. Mr. Breck, made wiser by the experiences of the year, acted with a degree of prudence and foresight which he had not before shown. He first sent a communication to the people, in which he said that, in the peculiar circumstances of this case, he should seek advice from his friends before he gave an answer to their call. He went soon after to Boston, and requested the pastors of that town, who were well-known throughout the Province, to examine him as to his views in theology. 'This they did, and as a result gave him a certificate ${ }^{1}$ that they had found him sound in the faith. They say: "These may certify that on the Sth day of May, 1735, we discoursed with Robert Breck,

1 This was signed by Benjamin Coleman, Joseph Sewall, John Webb, William Cooper, Thomas Foxcroft, Samuel Checkley, Joshua Gee, and Mather Byles. One of them said afterwards : "I can assure you that his examination was not a slighty one, if the ability and fidelity of the eight ministers that were concerned in it can be relied on." 
M. A., to our good satisfaction, concerning his orthodoxy in the great doctrines of Christianity, as believed and professed in the churches of Christ in New England, agreeable to the Westminster Confession of Faith; and so recommend him to the grace of God, and are his brethren in Christ."

With this indorsement he returned to Springfield, and on the 28 th of July accepted the call. The next step was to select a council for his ordination. The excitement in Springfield ran very high. Four members of the church presented a protest, which was entered upon the records. Twenty-seven members of the parish sent to Mr. Breck a remonstrance against his course in accepting the call before submitting himself to the judgment of the ministers of the Association as to his orthodoxy and as to his character. Mr. Breck replied that the council would be the proper tribunal to pass upon all these questions.

\section{VII.}

In the end the church voted, by a decided majority, to call a council for his installation. They selected four churches within the county, designating them by the names of their pastors, and left it with the pastor-elect, with a committee of the church, to select an equal number of churches outside the county. The council, as 
finally agreed upon, consisted ${ }^{1}$ of the church in Hatfield, Rev. William Williams, pastor; Hadley, Rev. Isaac Chauncy, pastor; Suffield, Rev. Ebenezer Devotion, pastor; Sunderland, Rev. William Rand, pastor; Brattle Street Church, Boston, Rev. William Cooper, pastor; Second Church, Boston, Rev. Samuel Mather, The Council Called. pastor; the New Brick Church, Boston, Rev. William Welstead, pastor; and the church in Sudbury, Rev. William Cooke, pastor. The council was to meet October 7 th.

Those who opposed the settlement of Mr. Breck denied the legality of the council for two reasons: First, because the votes of the church designated the pastors, instead of the churches to which they ministered; and because these votes left it with the pastor-elect and a committee of the church to select a part of the churches; and, Secondly, because the church had no right to call churches from outside Hampshire County. It was replied, on the part of the church, that what was done by

1 Mr. Williams was the oldest minister in the county, being 70 ; Isaac Chauncy (H. C., I693) was grandson of President Chauncy; Ebenezer Devotion, H. C., I707; William Rand, H. C., I724; William Cooper, born 1694, H. C., I712, junior pastor with Dr. Coleman, - "there was not a more decided Calvinist than he, yet he was a staunch advocate of religious liberty," - was elected President H. C., I737; Samuel Mather, son of Cotton Mather, H. C., 1723; D.D., - "was charged with looseness of doctrine;" William Welstead, H. C., 1 7 16, "an excellent Christian gentleman, and an exemplary minister;" William Cooke, H. C., 1716. 
its committee, chosen for the purpose, was done by itself, - that the letter missive, which went in the name of the church, was addressed to all the churches, by name, and that they had elected delegates to the council, showing that they understood the invitation. It was also claimed that they had a right to go outside the county for members of the council, as there was nothing in the Cambridge Platform to forbid it; and that in this case it was necessary in order to secure an impartial council.

It is not easy to understand, at this distance of time, the intense interest which this case excited, not only at Springfield, but in other parts of New England. The members of the council from Boston went to Springfield a week in advance of the meeting of the council, in order to consult with the ministers of the vicinity, and learn from them directly the grounds of their opposition. How abundant the leisure of those pastors of the olden time! It is a hundred miles from Boston to Springfield, and the stage-coaches, or ministerial chaises, of those days would be more than one day on the journey. Yet they went from town to town in the Connecticut valley, and tried to induce the pastors to submit their complaints against $\mathrm{Mr}$. Breck to the council. When the time for the mecting of the council came, the ministers of the county were present in Springfield to watch the 
proceedings, and to use their influence to prevent the ordination. The President of Yale College was also there, as the champion of orthodoxy, to direct the measures of the opposition. Rev. Thomas Clap and a number of other pastors from Connecticut were there, with documents to be presented to the council. It was confidently asserted by the opponents of Mr. Breck that whatever the council might do, "there would be no ordination."

In order to secure the fulfilment of this prediction, the dissatisfied members of the parish had induced three justices of the Court of Sessions to come from Northampton to Springfield, with the purpose of using the authority of the court, if necessary, to prevent the council from completing the service for which it had been convened. It was afterwards proved before the General Court that it was at first intended to arrest all the members of the council who had come from outside the county, and lock them up in jail, on the ground that their attempt to sit as members of a council in Hampshire County was an unlawful act, - an usurpation of power, - to the great injury of the minority. Warrants were actually made out for their arrest, but as one of the justices was doubtful as to their right to issue them, this plan was abandoned. The second plan was to arrest Mr. Breck, and hold him in custody until the council should adjourn. 


\section{VIII.}

WE may well suppose that when the day for the meeting of the council came business was suspended in Springfield, and that the people were eagerly watching the proceedings. The council met in the morning, not in the church, but in the house of Madam Brewer, the widow of the last pastor. Seven of the eight churches invited were represented by pastors and delegates. The church in Hatfield, of which the venerable William Williams was pastor, declined to respond, on the ground that the council was irregular and illegal. Proceedings of The council organized by choosing the council. Rev. William Cooper, of Boston, Moderator. Their first act was to invite the church - as well the minority as the majority - to lay all the facts in the case before them. Two papers were presented. The first was a remonstrance against the right of "the body calling itself a council " to ordain Mr. Breck, signed by William Pynchon, Jr., Esq., and others of the minority of the parish. The second was a protest against the right of the council to act in the case, signed by six pastors of the county. The council, after considering these papers, and the reasons which were set forth in support of them, voted: "That the elders and other delegates here assembled are an 
ecclesiastical council, properly called by the First Church in Springfield to join in the regular carrying on of the ordination of Mr. Breck, and are ready to hear, judge, and act in the case."

The council next called upon those who objected to Mr. Breck to present the evidence in support of the charges which they made against him. This they declined to do, on the ground that they could not recognize the body then in session as a regular and legal council. The Moderator next asked Rev. Mr. Clap and Rev. Mr. Kirkland, the authors of the charges, to let the council know whatever they knew against the candidate, which might disqualify him for the ministry. Mr. Clap proceeded to read a number of documents, most of them sworn to before a magistrate, with reference to the preaching of Mr. Breck while he was in Connecticut. These papers cover the whole case, and constitute the evidence on which the minority based their opposition. They are printed in full in the pamphlet published by the Hampshire ministers. Just as Mr. Clap finished reading the papers, and before Mr. Breck arrest of had commenced his reply, an officer the candidate. entered the room with a warrant for the arrest of "Robert Breck, gentleman," and for bringing him forthwith before the court then in session in the town-house, "To answer for such things as should be objected to him." Mr. Breck was taken by 
the officer from the council, and carried to the town-house. Proclamation was made that any persons who knew about the principles or the character of Mr. Breck should come forward and give testimony. Mr. Clap and Mr. Kirkland came forward and presented the evidence which they had just read to the council, with some additional statements. Mr. Breck was also examined by the justices as to his theological opinions. The evidence tended to show that he was not sound in the faith, and also that he had charged various persons with misrepresentation and falsehood. The old charge of taking books from the college library was also referred to in the testimony as a matter of common report. The proceedings seem to have been of the nature of an inquiry into the character of the candidate and his fitness to be a settled minister under the laws of the Province.

These proceedings of the secular power had the effect, of course, of suspending the session of the ecclesiastical council. Before adjourning, however, they sent a vigorous protest to the court, in which they say that they "consider it a duty not only to the church in Springfield, but to the churches which they represent, and to all the churches of Christ throughout the Province, to inform the court that when they sent their officer to apprehend Mr. Breck they were regularly and legally convened in council, at the desire of the 
church in Springfield, for the regular carrying on the ordination of said Mr. Breck, according to the order of the gospel in the churches of New England, and were actually hearing the charges against him when the court saw fit to wrest the case out of their hands." Having sent their protest, the council waited for the result. Mr. Breck was held in custody until night; and the justices gave orders to their officer to hold him till the next day. But certain members of the council gave their word that he should appear when called for, and he was permitted to go to his lodgings.

The council reassembled early in the morning, and continued the hearing of the case. Mr. Clap and Mr. Kirkland made oral statements as to the additional testimony they had given in court. The justices soon sent for Mr. Breck, and held him until late in the afternoon, when they made out a warrant which directed the sheriff to take him to Windsor, in the Colony of Connecticut, and deliver him into the custody of the County Court, "there to answer for those things which might be objected against him." He was taken to Windsor, and delivered to the officers of the court. He was permitted to give bonds for his appearance at a subsequent time to answer to a charge concerning the doctrines which he had preached while within that Colony.

These proceedings increased very much the 
excitement among the people at Springfield. The church appointed a committee to attend him, " in token of respect as their pastor-elect, and the people gave evident marks of their affection for him as he went through the town." The next day they assembled in the meeting-house to pray for his safe return. The record says: "It was a large and weeping assembly." A day or two later, Mr. Breck returned to Springfield, and the council resumed its sessions. They considered more fully the charges and the testimony for and against him, and listened to his reply. The decisive paper in the case was a Confession of Faith which he drew up for the satisfaction of the council, as a statement of his mature opinions concerning the leading truths of the Gospel. ${ }^{1}$ It is a serious and

1 In this Confession, which is too long to insert entire, he declares his belief in one God, who is also triune; in the Holy Scriptures, which are of divine authority, and which have been preserved by God's providence "pure and uncorrupt;" in the decrees of God, by which, whatsoever comes to pass in time has been foreordained from all eternity, _- "yet so as not to take away the will of His creatures, or make Himself the Author of $\sin$;" in the providential government of the world; in the first covenant with Adam; in his fall from his first estate, which involved the race " in his guilt and corruption ;" in the covenant of redemption, and the vicarious sacrifice of the God-Man, "which satisfied divine justice for the sins of the elect, and reconciles them to God;" in the work of the Holy Spirit, "who makes effectual application of the benefits of Christ's redemption to the souls of men;" in the inability of fallen man to that which is spiritually good, and the necessity of effectual calling by the Almighty Spirit; in the imputation of the righteousness of 
definite statement, following substantially the Westminster Confession, and, by implication, renouncing most of the errors which he had been accused of preaching in Connecticut. After reciting the statement of his belief, he said: "This is the scheme of Christian doctrine which I have learned from the Holy Scriptures, and which I shall think myself obliged to teach others in the best manner I am able, while at the same time I put them that profess to believe in mind that they be careful to maintain good works. It is my prayer that my knowledge of these things may be enlarged, my faith of them confirmed, and that I may be enabled always to keep the mystery of the faith in a pure conscience." This Confession was satisfactory to the whole council. It was read by a man on horseback, to a great crowd of people who assembled in the street in front of the house in which the council was holding its sessions; and was subsequently read by the candidate to the congregation at his ordination. The council, after a full consideration of the case, came to a Result in which they said, that they found that Mr. Breck had been regularly called by a very great majority

Christ for their justification; in the work of sanctification; in the final perseverance of the saints; the eternal separation of the righteous from the wicked; the righteous for life eternal, and the wicked for everlasting punishment. 
to the church and precinct of Springfield; and also that he was sound in the faith, and of good conversation; so that they advise the people "to continue their regards for him." "Nevertheless," they say, "having met with an unusual interposition and hindrance in carrying on the work upon which we were called, we do not think it advisable to proceed further herein at this time, but that this council be adjourned " to meet in Boston, October 2 Ist. The Moderator remained in Springfield over the Sabbath, and read this result to the congregation.

\section{IX.}

THE object of the adjournment was not only to allow time for the excitement to subside, but also to test the legality of the interference of the secular authorities with the work of the council. Two weeks later, the church appointed a committee to bring the matter before the General Court. This committee presented a memorial to the General Court on the 25th of November, in which they stated the fact of the call of Mr. Breck by a very great majority of the church and precinct, and the convening of a council for his ordination, and say that "on the day appointed for that solemnity John Stoddard, Ebenezer Pomeroy, and Timothy Dwight, Esqrs., his Majesty's justices of the peace for the County 
of Hampshire, had caused him to be arrested and taken from the aforesaid ecclesiastical council, and brought before them, and that they examined him touching divers points of doctrine; and, further, that by a warrant from the said justices, he was sent to Windsor, in the Colony of Connecticut, where he was bound over by appeal to the the County Court to answer to a charge General court. touching his doctrines." They ask the General Court to decide whether these proceedings have been according to law, and if not, to grant such redress as the case admits.

The journals of the General Court show that the case was very fully considered by that body. It was first assigned to the $5^{\text {th }}$ of December, at which time the papers were read. It was voted to inquire into the matter of complaint, and to appoint a committee to report what action ought to be taken. Notice was sent to the justices at Northampton, and to other parties interested. The General Court heard not only the committee from Springfield, but Mr. Breck, and the Moderator of the council, and various other persons. The matter was before the Court December $5^{\text {th }}$ and 6th, 9th, 24th, 26th, and $27^{\text {th }}$. The decision was; First, that the council was duly called, and was properly and legally a council, according to the usages of the churches; and, Secondly, that the justices had no right to "interrupt the church 
and ecclesiastical council, while they were, in the exercise of their just rights, investigating the case."

Strengthened by this decision, the council, which had been continued by successive adjournThe ordination. ments, reassembled at Springfield on the 27 th of January, 1736 , and " finding that the people did abide firm in their choice of Mr. Breck, and their desire to have him as their pastor," they proceeded to ordain him as pastor of the church. The sermon was preached by Mr. Cooper, the Moderator, from Matthew xiii. 3. In this sermon, which was printed, Mr. Cooper bears this testimony in respect to the young pastor: "I think myself bound to testify, on this occasion, that in all this time I never heard one hard word drop from you respecting any person of any order. I have seen your tears, admired your silence, and hope God has heard your prayers. May the fruit of all be to humble you, to prove you, and to make you a greater blessing to this church and people."

\section{$\mathrm{X}$.}

Those who were opposed to Mr. Breck made one more effort to prevent him from continuing as the minister of the church. They signed a complaint to the Court of Sessions for the county, 
which set forth that the church in Springfield was destitute of a minister duly settled according to law; that one Robert Breck had taken upon himself the office of pastor, under pretence that he had been ordained; that the said Breck is not qualified, according to the laws of this Province, to be a Gospel minister, inasmuch as he is not orthodox in his belief, and not of good conversation; that, according to law, there can be no money raised for the settlement and support of any person in the ministry but such as are orthodox and of good conversation. They therefore ask the court to make such order in the premises "that some suitable person may be settled in the pastoral office in said church, it being contrary to the law of this Province, and the peace of the king, that a person of such principles and conversation should take upon himself the office of a minister, or that the said church should be destitute of a settled minister." The court took this petition into consideration on the $2 \mathrm{~d}$ of March, and summoned the church and parish to appear and answer the complaint. The parish appointed a committee of five, of which William Pynchon, Jr., Esq., was chairman, to represent them before the court, and instructed them to "carry the case as far as necessary, from court to court, in order to a final determination of the matter." As there is no further refer- 
ence to the case in the records of the parish, it is probable that it never came before the court for trial.

These proceedings were followed by a number of pamphlets, which are the authentic sources of information concerning these matters. The first was published in Boston, I 736, a few months after the ordination had taken place. It is entitled "A Narrative of the Proceedings of those Ministers of the County of Hampshire that have disapproved the Settlement of Mr. Robert Breck." It is a vigorous pamphlet of about one hundred pages. This was followed the same year by "An Answer to the Hampshire Narrative." This also contains one hundred pages. It is said to have been written by Rev. William Cooper, of Boston. The next year appeared another thick pamphlet, with the title, "A Letter to the Author of the Answer to the Narrative."

\section{XI.}

WhiLE these proceedings in court, and this war of pamphlets were going on, the young pastor set himself to conciliate the opposition among his people. He gave himself to the duties of his office with exemplary fidelity. It is said of him, that if he wished any favor he would ask it from some one of his people who had been unfriendly. Such 
an expression of his confidence won their good will. He chose his wife wisely also. He marricd, a few weeks after his ordination, Eunice Brewer, the daughter of his predecessor, who had been universally loved and revered. He invited Rev. Stephen Williams, of Longmeadow, who had been one of the most decided of his opponents, to perform the marriage ceremony; and this act of courtesy is said to have modified his opposition. In a few years, he was accepted by his brethren in the ministry, as well as by his people, as a minister "able, learned, orthodox, and of good conversation."

Mr. Breck was the pastor of the church in Springfield forty-eight years. The church grew with the town, and its minister became a man of great influence in the ConnectiThe Pastor. cut valley. It is more than a hundred years since his death; but the traditions concerning him at Springfield are still fresh, and he is held in great esteem and veneration. His funeral sermon was preached by Dr. Lathrop, of West Springfield, who had been a student in divinity under him. In this sermon, he said: "His intellectual powers were naturally superior, and were brightened by his education, and enlarged by an extensive acquaintance with men and books. He accustomed himself to a close manner of reasoning and thinking, and filled up his time with diligent application. 
History was his amusement, divinity his study; he excelled in both, especially the latter. He was an accomplished gentleman, and an exemplary Christian. His attendance on the duties of his profession was constant, his preparations for the sanctuary were mature, his public prayers were deliberate and solemn, his sermons were full of thought, - dressed in the most proper language, and communicated in the easiest manner. His religious sentiments were formed on a careful examination of the Scriptures, without servile attachment to sects or systems. His turn of thinking was liberal yet Scriptural, exalted yet humble."

Such was the man as he seemed to his contemporaries at the close of a pastorate of half a century. 


\section{VIII.}

The Religious Life in the Eighteenth Century in Northern New England.

Brunswick, Maine. 

The Religious Life in the Eighteenth Century in Northern New England.

\section{Brunswick, Maine. ${ }^{1}$}

$A^{T}$ the close of the seventeenth century, less $A$ than half of what is now called New England had been settled. There were a few strong towns in New Hampshire, and a few settlements on the coast of Maine. As the people of Puritan descent pushed their way northward, to settle and cultivate what is now Maine, New Hampshire, and Vermont, they organized their towns and their churches according to the Puritan models. Those new communities passed through experiences not very different from those through which the people in southern New England had passed a hundred years earlier. It was, in many respects, the Puritan history over again.

Yet there were decided differences between the older and the newer churches. Many of the most perplexing questions had been settled during the first generation. There was a well-defined polity

1 An Address at the Hundred and Fiftieth Anniversary of the Congregational Church in Brunswick. 
for the churches. The system of administration had been slowly learned from experiences in the town and the county and the Province. The new

Difference between the older and Newer Churches. churches were likely to receive encouragement and material aid from the older and stronger churches. Southern New England did a great deal of Home Missionary work in northern New England, long before the west was opened for such work. There was a greater diversity of race and nationality when the later churches were gathered. In many of the newer towns the Scotch Presbyterians were as numerous as the descendants of the Puritans. It took a generation or two for these elements to harmonize. The war of the Revolution affected these newer settlements more than it did those that were older, because they were more exposed to attacks from the Indians, and from the English in Canada.

It is worth while, therefore, to study the religious life in northern New England in the eighteenth century. To do this, let us take a representative church in Maine, in the town of Brunswick, which was settled in the early years of the century. The first settlers began very early to make provision for the preaching of the Gospel. Sometimes at Fort George, sometimes in private dwellings, or in barns, and later in the first meeting-houses, - for there were two, on opposite 
sides of the township, - they came together to worship God. It is plain, from such records as have come down to us, that the early settlers cared a good deal for these religious services.

I.

Among the reasons which the inhabitants of Brunswick urged, in their petition for a charter, in 1735 , were these: "That a commo- The Petition dious meeting house has been erected, for a charter. and a pious and orthodox minister secured," and that they desired to be vested with power to tax themselves for his maintenance. This commodious meeting-house was located midway between the old Fort and Maquoit. The History of the town contains a picture of this meeting-house. It was a plain building, facing the south, with a projecting porch, but without a tower or steeple. The records do not give the dimensions of the edifice, but they give glimpses of its interior. The walls were unfinished; there was no ceiling; the roof timbers were in view; there was a high pulpit, with a sounding-board above it. There was a gallery, and both the gallery and the floor of the church had pews, large and square; and each pew had seats on three sides. The environment of this "commodious meeting-house" was characteristic of the times. In front stood the stocks; in 
the rear was the whipping-post; near by was the graveyard. North of the graveyard was a pound, with a substantial fence, and a gate securely locked. Within the house, far up under the roof, was a loft used as a powder magazine.

\section{II.}

THIS was the place of worship for the people of the west side of Brunswick for about seventy years, until after Bowdoin College was founded. The Early In that pulpit Robert Rutherford Ministers. preached seven years, and Robert Dunlap thirteen years, up to I 760 . Those were times of great peril to the pioneers, when block houses were built for defence against the Indians. It is related that when Mr. Dunlap went to Newmeadows to preach, he was escorted by his neighbors, who went armed to the place of prayer. In that pulpit also, John Miller preached twenty-four years, which included the period of the Revolutionary War, and Ebenezer Coffin eight years. These together cover fifty-two years of somewhat regular pastoral work in the eighteenth century. ${ }^{2}$

${ }^{1}$ History of Brunswick, 637.

2 Rev. Robert Rutherford was a native of Ireland. He came to this country in 1729 , preached in Pemaquid four years, preached in Brunswick, 1735-1742. He died 1756, aged 68. History of Brunswick, Soz.

Rev. Robert Dunlap was born in the parish of Barilla, County of Antrim, Ulster, Ireland, August, I71 5, was educated in the Uni- 


\section{III.}

THESE are the outward facts. But underneath all this there must have been a religious spirit and life of which we can gain little knowledge from any records that are now extant. The records of the First Parish relate very naturally to secular matters, such as the arrangements for the settlement and the dismission of pastors, the assessment of the parish taxes, repairs of the meeting-house, and other matters of a business nature. Whenever there was The Spiritual any lack of harmony among the memLife of the Church. bers of the church, it was very apt to leave some trace upon the records. It may be that such records give undue prominence to these things. But of the spiritual life of the people, - of their religious habits, of the quality of the preaching they were able to get, of the doctrines which they

versity of Edinburgh, was Master of Arts at nineteen, came to this country in 1736 . He was a Presbyterian, preached at various places in Massachusetts and in Maine, was engaged to preach in Brunswick in 1746 , on a salary of $£ 200$, and ordained in Boston, in $17+7$. He was dismissed in 1760 . He died in Brunswick, June 26, 1776. History of Brunswick, 728.

Rev. John Miller, of Milton, Mass., was engaged in Brunswick, December, I76r, and installed as pastor the next year, and continued his ministry there about twenty-four years. He died in Boston in 1788 . History of Brunswick, 773.

Rev. Ebenezer Coffin was ordained as pastor of the cliurch in Brunswick in January, I794. He continued his ministry there about eight years. 
accepted, and of the spiritual power of the Church in the last century, - the records give us less information than they do of the votes passed to determine the location of the meeting-house, or the salary of the minister. We should like to know more than we do of the religious life of the people who lived in those times of simplicity and of comparative poverty. In respect to these matters, the indirect evidence is more abundant than that which is direct.

\section{IV.}

One thing which affected the religious life in Brunswick was the connection of the Church with Connection of Church and the state. It is not quite certain that State. the church had been organized when Mr. Rutherford became the minister, by vote of the town of Brunswick, or even when Mr. Dunlap began his ministry. The people of the town called the minister by vote in townmeeting. The contract was made between the town and the minister. His salary was raised by a tax, levied upon all the rate-payers. After the church was organized, it had the right, under the laws of Massachusetts, to choose its minister, and the town had the right to accept or reject the candidate whom the church had selected. The laws required that every town should be constantly provided with a minister, and if it should 
neglect for six months to secure an "able, learned, and orthodox minister, of good conversation," the town was liable to be prosecuted and fined for such neglect. Brunswick was prosecuted and fined in I8Io under that law. It was not always easy for the church and the town to agree in the choice of a minister. In a good many instances the minister who had been chosen by the church was rejected by the town. In I 786 , the town voted to dismiss the pastor, but the church voted to retain him. Whereupon, the town voted not to raise any money for his support.

There was always more or less trouble in collecting the tax levied for the support of the pastor. Twenty-one persons were sent to jail, in a parish not far from Brunswick, because they refused to pay the tax assessed upon them for the support of the minister of the town. ${ }^{1}$

The connection of Church and state did not work as well in Maine as it had done in Massachusetts. It was not as easy to continue that connection after the Revolution, as it had been before. The growth of a spirit of personal independence, under a republican government, and the increasing diversity of religious opinions, made it a hard matter for a church and a town to get on with harmony and good feeling in the support of religious institutions. So that the time came, in

1 Mr. Harlow's Address at Cape Elizabeth. 
the natural course of events, when the connection which had existed so long became a hindrance to the prosperity of religion in the town.

\section{V.}

THE difference of opinion in respect to Church government was also a great obstacle to the prosperity of religion in Brunswick. The first church

Congrega-

tionalism and Presbyterianism.

was probably organized as a Presbyterian church, and in its earlier history it was connected with the Presbytery of Londonderry. Mr. Dunlap was a Presbyterian from mature conviction, as well as by his training. The people in the west part of the town were, for the most part, Scotch-Irish Presbyterians, while those at New Meadows were Congregationalists. The Presbyterians were the more decided in their preferences, because that had been the polity of their fathers. The Congregationalists were not disposed to yield, because New England was full of churches of their order, and theirs was, in some sort, the State Church. There were never more than ten Presbyterian churches in Maine at one time, while the Congregational churches in the district greatly outnumbered them. In a small town on the frontier, a hundred years ago, the questions between these denominations seemed more important than they seem to us at this time. 
Nevertheless, there was a spirit of conciliation. In I774, the church in Brunswick voted that the Sacrament of the Lord's Supper should be administered "at the West meeting-house from the long table, the communicants sitting around it, or in the body-pews, as they might see fit;" and that in the East meeting-house it should be according to "the Congregational form." "Baptism was to be in either form, as persons might choose." There was a difference in respect to singing, and, in $\mathrm{I} 786$, the town voted "to allow the people at the Eastend to regulate the way of singing in Divine service in the East-end as they shall think proper." The same year, the church voted against the new way of singing adopted at the East-end of the town, and directed that the psalms and hymns should be read by the deacon, line by line. Some in the church desired to have ruling elders appointed, while others wished to have deacons. The discipline of the church suffered on account of these disagreements, and the relation between pastor and people was sometimes weakened by them. But, as the larger number of those who came to Brunswick from other places were Congregationalists, the Presbyterians gradually lost the control, and, by the end of the century, the church had become to all intents a Congregational church. This tendency was strengthened by the establishment of Bowdoin College. 


\section{VI.}

Through all this period Brunswick was but a modest and obscure settlement among the pines. On every side except the river, the divellings stood close up to the forest, which stretched away for miles. The principal business of the place was the trade in lumber. ${ }^{1}$ The people commonly condition of went on foot to the church. Some of the People. those who lived at a distance owned a horse, a saddle, and a pillion, which would accommodate a man, his wife, and one or two children. It is a matter of dispute whether there were two or three wheeled chaises in town before the Revolution. The New England meeting-houses were not warmed in the last century, and those in these northern regions were not lighted. The people who came in from their long walk through the snow were a strong and hardy race, else they could not have endured the cold, as they sat, in this unfinished house, through the long services. The services in those days were held in the day time.

But through all this period of hardship and poverty the church continued to grow and to prosper. There is reason to believe that public worship was maintained with a good measure

1 History of Bowdoin College, 2, 83. 
of regularity, - that the sacraments of the Church were administered, and that the standard of piety was a high one. We have the names of more than a hundred who Prosperity of were members of the church before the Church. the year ISoo, and the list is known to be incomplete.

The service of song in the last century was more simple than it is now. The num- The service ber of tunes used in public worship was of Song. very limited, and there was probably no instrumental music in the earlier years. The choirs were large in those days, and the chorister was a person of great importance. In $176_{3}$, the cisurch voted to use "the version of the psalms by Tate and Brady, with the hymns of Dr. Watts annexed thereto."

\section{VII.}

THE ministers of those times had a position in the community very different from that of their successors in this century. They were still settled for life. The towns were required by law to pay their salaries. They were distinguished from other people by their dress and their the Ministers manners. The description of Rev. of those Days.

Samuel Eaton, minister in Harpswell from 1764 to 1822 , by Professor Alpheus S. Packard, is very graphic. "He was above the average stature, 
with a large frame, and full habit. His entrance into the church, on the Sabbath, and his stately progress up the broad aisle, - bowing to the sitters on each side, according to the custom of those days, always attracted attention. He wore a broad skirted coat, with wide pocket flaps, a waistcoat flaring in front, and falling to the knees, breeches, high shoes with large plated buckles, - the whole surmounted with a capacious wig and a cocked hat." 1

Yet those ministers, with all their dignity, and stateliness, had a great deal of human nature about them. They put on their courtly manners, according to the customs of their time, but there was genuine manhood underneath the manners. The pictures of President McKeen which we are accustomed to see, represent him in the dress of his times, with his long hair gathered in a queue. He was the pastor of the church in Beverly, Massachusetts, from I $7 S_{5}$ to I 802 . He was above the ordinary stature, and of commanding appearance, and clignified manners. In the earlier years of his ministry, he was fond of athletic sports. One day a visitor at his house in Beverly was boasting of his strength and skill as a wrestler; whereupon the minister invited him to retire to a suitable place that they might both test their abilities in that line. The proposal was accepted, and they

${ }^{1}$ Sprague's Annals, vol. i. Samuel Eaton. 
went out. But the minister was too much for the athlete and, after repeated falls, he acknowledged that the pastor was the better man. ${ }^{1}$

The use of intoxicating drinks was more common in those days than now. Parson Smith speaks of an ordination at New Gloucester, in 1765, as a "jolly ordination." He says, "We lost sight of decorum." The progress of the ministers toward the practice of total abstinence from strong drink was slow. It was not till $\mathrm{I}_{8} \mathrm{I} 3$ that the Cumberland Association voted that "there be no ardent spirits used by the Association as a body in future." 2 That vote casts a suggestive backlight upon the social customs of our clerical fathers.

\section{VIII.}

WhAT were the religious teachings in the old meeting-houses?

We have a good many sources of information. In the latter part of the eighteenth century the opinions that had been held by the older Puritans had been modified, partly through the influence of President Edwards, and the divines of his school, and a more liberal, and, as we think, a more Biblical, theology began to be preached. Mr. Dunlap had been trained in the more rigid Scot-

1 Sprague's Annals, vol. ii. Joseph McKeen.

2 Centennial Pamphlet, Cumberland Association, 24, 33. 
tish School. He is said to have been vehement, and persuasive in his style of preaching, and to have taken the celebrated Mr. Whitefield, whom he had met soon after his arrival in this country, as his model. But his successor, Mr. Miller, was a decided Congregationalist, and he probably preached the New England theology. He is said to have been very charitable in his treatment of those who differed with him in religious matters.

Religious All the ministers of the church in Religious
Views of the Brunswick during the last century were Ministers.

Calvinists (except possibly, Mr. Coffin), and they gave their people the strong meat of the Gospel.

That was before the time of Sunday-schools

^ in New England. The children were taught the catechism at home, and in the day-schools. They were also catechised by their pastors. The Bible was carefully taught to the children, in the last century, by their fathers and mothers; and it is not certain but they had a better knowledge of the Scriptures, and of the religious truths which they teach, than the children of our own times.

\section{IX.}

THE methods of pastoral visiting in the last century were more systematic and thorough than those to which we have been accustomed. The 
ministers were expected to go from house to house, and teach religious truths to the people, especially to the young people. They were also in the habit of conversing visiting. with each individual in regard to his religious duties, and to use their personal influence to lead them forward in a religious life. Here is a record made by a pastor in Maine of his method of pastoral visiting in 1766 , and preserved for us in Greenleaf's Ecclesiastical Sketches: "First to salute the house:-compare the lists with the family: and note how many know the catechism, - how many have taken the covenant, - and how many are church members. Then, to exhort the young people to give attendance to reading, - to secret prayer, - to public worship, - the observance of the Sabbath, - to live peaceable and faithful lives, - to seek the grace of God, and a true conversion. To address parents about their spiritual state, - secret devotions, - family worship, - government, — catechising, - public worship, - the sacraments, - if they are church members, see to what profit, - if in error or vice, to reclaim, - if in divisions, heal, - if poor, help, - lastly, pray with them all." 1

It is not surprising that the pastor who followed that method, relates that after a few months of that sort of work, there was a general revival of

1 Greenleaf's Sketches, 133, note. 
religion in the town: "A solemn, sweet, and glorious season," that "many of God's people

Revivals of were filled with the joy of the Lord, Religion.

and that many were brought to see their need of that Saviour whom they had shamefully neglected, and wickedly crucified." It is not surprising that this work of grace extended into the adjoining towns.

The revivals of religion, during the latter part of the eighteenth century, were very wonderful. I have read of a work of grace in Harpswell, Maine, in 1756 , which brought sixty-seven persons into the church, in that small community; of another, in North Yarmouth, in I79I, which pervaded the whole town, and brought one hundred and fifty into the church; of another in New Gloucester, in I 791, which was exceedingly powerful. ${ }^{1}$ These revivals were all in the vicinity of Brunswick. It is well known that the last years of the last century, and the earliest years in this, were marked by very thorough and extended revivals of religion in all parts of New England.

The establishment of Bowdoin College at Brunswick has had a great influence upon the church. The first building for the College was erected in 1798 . It was ready for use in $\mathrm{ISO} 2$, at which time a house was erected for the President. The first class was graduated in 1806 .

${ }^{1}$ Greenleaf's Sketches, 69-70, 66-67, I19-120. 
President McKeen (elected I80I) used to preach on Sunday, either in the meeting-house of the First Parish, or in the College chapel. From that time to the present, there has been a close connection between the College and the church. This connection has given to the church a great increase of influence and of usefulness.

\section{$\mathrm{X}$.}

IF I were asked to state the essential and permanent qualities in the religious life of New England, during the eighteenth century, I should answer: To-day is the child of yesterday, - this century is the child of the last century. New England owes its spe- The Permanent cial characteristics to the Pilgrims and Qualities of the the Puritans. The religious life into of that Century. which we have entered is a continuation of that of our fathers. They planted the seed, and we are reaping the harvests. If we have made some improvements in theology, so did they. If we have entered into the work of reform, so did they. If we have been favored with revivals of religion, so were they. Our Bible and Tract Societies, our societies for Home, and Foreign Missions, which grew up in New England in the earlier decades of this century, are the results of their religious training and example. That 
which we are doing, with our more abundant means, and our more fortunate environment, to make human life sweeter, and purer, and to make the world freer and happier, and to enlarge the kingdom of Christ among men, - much of this is the flowering and fruitage from the planting of our fathers, who in the great straitness of their lives, with much self-denial, and with devout prayer laid the foundations of our free Christian Commonwealths. The Pilgrims and the Puritans did not live in vain. Their influence has gone out into all the earth. We are drinking at the fountains which they opened. We walk in their light, and we are to pass on the torch to other generations. 
Index. 



\section{Index.}

Aвbott, George, Archbishop of Canterbury, 48 ; one of the translators of the Bible, favors the Puritans, $4 S$; seeks to make peace in the Church, 49.

Afternoon Service of Worship in Puritan Churches, I54. Agreement at CaMbridge, England, 71.

Alden, John, 242 ; his new home, 245 ; marriage, 246.

Amusements or: the Pilgrims and Puritans, 262 ; games of chance forbidden, dancing, 262 ; simple rustic pleasures, 263 ; Harvest Festival at Plymouth, 263; not religious, 264; training days in Boston, 264; guests at the house of the Governor, dinner parties described in the Diary of Judge Sewall, 264; Commencement week, 264; Hawthorne's Scarlet Letter, 265.

Association, Hampshire, of ministers, 337; members of, 337; receives charges against Mr. Breck, $3+4$; advises against his settlement, $3+8$; provides for an investigation of the charges, 349 ; opposes the installation, 356.

Augustine Quoted, 208.

Awakening, The Great, $3 \mathrm{I} 4$; influence of, 338 ; connection of the New Divinity with the revival, 339 .

Bacon, Dr. LeONARD, 85, 90 .

BACON, LORD, on reform of Church, 35, 37.

BANishmeNt of Roger Williams, I7I, I73; the sentence revoked, I 73 .

BAptisir of Children, 153-154; church membership of children, 308 ; consequence of this doctrine, 309 .

Bay Colony, The, IO2-IO3.

BAY-PATH, 191 .

Bay Psalm Book, 150.

Bible, love for, and obedience to, II 8 ; not read in public without exposition, 163 . 
Blue Laws of Connecticut, 251; the irvention of Samuel Peters, 252 ; his book, 252.

BODY OF LiBERTIES, 255.

Books introduced from the Continent, 21.

Bradford, Governor William, 58, 90, I 59, 233, 244.

Breck, Rev. Robert, Ancestry, 342; graduated at Harvard, approved by the Faculty, 343; began to preach in Connecticut, called to Springfield, 343; opposition to his settlement, 344 ; charges against him, 344-345; his reply to the charges, 346 ; declines the call, 347 ; returns to Boston, 347 ; advice of the Association to the Church, 348; Mr. Breck again invited to preach in Springfield, 349; action of the Association, 349; objections to the method of investigation, 350 ; the second call of the church, 35I ; certificate from the ministers of Boston, 352; accepts the call, 352; his Confession of Faith, 360; arrest and removal to Connecticut, $35^{8}$; return, 360 ; is ordained, 364 ; marriage, 367 ; his life and work as a pastor, 367 ; his funeral sermon, 368 .

Brewster, Elder William, 52, 90, 105, 124, 244-245; his dress, 259; furniture, 260.

Brooks, Phillips, 275.

Browne, Robert, views of, 22-24; pastor of the Separatist Church, persecuted, 24 ; returns to the Established Church, 24.

BRUNSWICK, MAINe, 372; early provision for preaching, 373; reasons for seeking a charter, 373 ; Church and State, 376; condition of the town, 380 ; founding of Bowdoin College, $374,388$.

BURR, JOHN, I94.

Cable, John, 190.

Calvinism, Preached in New England, 321 ; influence of, 322 ; strong type of Christian character, 322 ; defenders of liberty, 323; vigorous type of manhood, 323; small number of church members, 324 ; children of the Puritans not members of their churches, 325 ; "unfruitfulness of the means of grace," 326: compared with results of modern preaching, 326; frequent religious declensions, 327 ; testimony of Prince, 327; Salem Witchcraft, 327 ; dissensions in the churches, 328 ; growth of Arminianism, 328; influence of the Edwardean theology, 329; successors of Edwards, 33I ; New England Theology, 33I.

Calvinism tends toward Liberty AND Democracy, 4I, 222. 
Calvinistic Doctrines of the Puritans, $4 \mathrm{I}$; Synod of Dort, 284 ; teachings from Geneva, 285.

CAMBridge Agreement, I629, 7I, I79, IS6.

Cambridge Platforni, 107, 341 .

Cambridge Synod of 1646 , 107 ; called by the General Court of Mass., I 78 ; contained delegates from the other colonies, I79; adopts the Cambridge Platform, I79; accepts the Westminster Confession, 291.

CAmbridge the Puritan University, I21.

Carver, Governor John, 90.

CATHOLIC POWERS UNFRIENDLY to Elizabeth, 31 ; the Spanish Armada, 31, 42; St. Bartholomew, 32 ; Duke of Alva, 32; Thirty Years War, 34, 50.

Charles the First, 59; his first Parliament, 60; the Petition of Right, 6r ; demands forced loans, 63; his tyranny, 69-70; grants the charter of Massachusetts, 70 ; demands ship money, 72, 74; the Long Parliament, 71, 74, 75.

Charter of Colony of Massachusetts, 70, 188.

Church and State in England, 39.

Church and State in Maine, 376; the minister paid by the town, 376 ; trouble in collecting the tax, 377 ; increase of independence after the Revolution, 377; towns required to pay the salaries, $38 \mathrm{r}$.

Church and State in Massachusetts, 339; qualifications of ministers, 339; method of choosing a minister, 3 to ; the salary to be raised by a tax, 370; the General Court to select a minister if the town neglects, $34 \mathrm{I}$; the Cambridge Platform, 341 ; questions that frequently caused divisions, $3+2$.

Churches, Independent, 94; model of Scrooby, I58; Plymouth Church, 158 ; Salem, I 59 ; officers of, 160, 287.

COFFEe not used, 139 .

Coffin, Rev. Ebenezer, of Brunswick, note on his life, 375; his religious views, 384 .

Committee of Religion, 74 .

Common Schools, reasons for, 248 ; Governor of Virginia dislikes, 248; schools in the Dutch Republic, 248; in Plymouth, 2.49; Boston, general law, 250 ; schools in New Haven, 250; Hartford; influence of, 250 .

Comparison OF THE PILgrims with the Puritans, $8_{5}$, 112 ; why the Pilgrims came, 83 ; why the Puritans came, 83 ; difference in date of settlement, 86 ; Separatists and Non-Conformists, 87; social position of the Pilgrims, 89; of the Puritans, 90: 
objects of the Pilgrim Colony, 9I, IO2; objects of the Puritans, 92 ; government of the Pilgrim Colony, 98, 99 ; government of the Puritan Colony, IOO; numbers and wealth, IOI; ministry at Plymouth, I04; confederacy of the colonies of New England, I08; legislation in the two colonies, I09-II2.

Confederacy of New England Colonies, Ios.

Connecticut River Joint Commission, i93.

ConneCticut SetTled, 169-I93, 240.

Contributions on the Sabbath, I55.

CoOper, Rev. William, member of the Council at Springfield, 353 ; moderator of the Council, 356 ; speaks before the General Court, 363 ; preaches the sermon, 364 ; writes one of the pamphlets, 366 .

Cotton, John, I00, I06, I0S, I21 ; scholarship, I22, I27, I32 ; midweek lectures, 156, 213, 267; Catechism, 286.

Council at Springfield, called, 352; members, 353; its regularity questioned, 353-354; meets in Springfield, 356; remonstrances presented, $35^{6}$; testimony given, 357 ; arrest of $\mathrm{Mr}$. Breck, 357 ; protest from the Council, $35^{8}$; he is sent to Connecticut, 359; meets the next day, 359; return of Mr. Breck, 360 ; his statement of belief, $360-361$; result of the Council, 361 ; adjournment, 362 ; re-assembles, 364 ; ordains Mr. Breck, 364.

Court of Mr. Pynchon, 196.

Court of General Sessions at Springfield, 355 ; arrest of $\mathrm{Mr}$.

Breck, 357 ; examination as to his religious views, $35^{8}$; sends him to Connecticut, 359 ; investigates complaint against the Church in Springfield, 365 .

Courtship of Miles Standish, 242-246; poetic license, 242; its historic basis, characters from real life, 243.

Cranfield, Governor, ilig.

Creeds of The Churches, 287 ; grew out of covenants, 287 ;

creed of the Church in Salem, $2 S 8$.

Crouwell proposes to remove to America, 70; Lord Saye and

Sele, Lord Warwick, and other Puritan noblemen, 70.

Culture of the Puritans, 7S, 79, 222-225.

Cushman, Elder, 105.

DaVEnPORT, John, I 24, I 27 ; pastor of the Old South in Boston, 3 I I.

Decline of Protestant Power in Europe, 33.

Descendants From the Puritans of the seventh generation, 273-277. 
Dexter, Dr. Henry M., 24.

Dignifying the Seats, i 43.

DRESS OF THE Colonists, 258 ; dress of officials, 258 ; portraits of Puritans, I26, 258; laws against extravagance, 259; dress of Elder Brewster, 259.

Druillette, Father Gabriel, a Jesuit missionary, 268 ; sent to Boston, 269; to Plymouth, 270 ; visits the Apostle Eliot, 270. Dudley, Thomas, $185,203$.

DUNLAP, REv. ROBERT, of Brunswick, birthplace, 374 and note, also, 375 ; salary paid by the town, 376 ; a Presbyterian, 378 ; manners and theological views, 383 .

DWEllings of MiNisters, 135 .

Eastern Counties of England, full of Puritans, 33.

Eaton, Rev. Samuel, of Harpswell, 38 I.

Edward the Sixth, a Piotestant king, II ; Book of Common Prayer, II, I3.

Edwards, President Jonathan, 133, 299; revival under the preaching of, 3I3; new divinity, 3I4; the younger Edwards, 328 ; improvements in theology by President Edwards, 329 ; influence upon the theology of New England, 330; influence in the Connecticut Valley, 337, 338 .

Eighteenth Century in New England, 37I; difference between the settlement of Northern New England and Southern, 372 ; mingling of nationalities, 372 .

Eliot, John, record concerning Mr. Pynchon, note, 213; receives

Father Druillette, 27I.

Elizabeth, a Protestant Queen, I2; Act of Supremacy, I3, I6 ; Act of Uniformity, I3 ; Court of High Commission, I6-19, 64; increased severity against Non-Conformists, I6; Whitgift, I8 ; subscription to the Thirty-nine Articles required, 19; growth of Puritanism, 30; death of the Queen, 30 ; character, 40.

Elizabeth, compared with Victoria, 235.

EndicotT, Governor John, 96, 203.

Estimate of the Puritans by English historians: Macaulay,

3; Hallam, Hume, Carlyle, 3; John Richard Green, xxxvi, xl,

I4, 4I, 44, 221 .

Excommunication of Non-Conformists, 65.

FARMERS, early ministers were, I33.

Food in early Puritan times, 137.

FreEdom of Religion in Holland, 53. 
French of Canada, 265, Roman Catholics, 266; visits of La Tour, I643 and I646, 267; Druillette, 268.

Fuller, Dr. Samuel, 96, 97.

Funerals, methods of conducting, 164 .

Furniture of the PIlgrims and PuRitans, I35; inventory of the furniture of Elder Brewster, 260; inventory of household goods of Governor John Winthrop, 260; of Mrs. Martha Coytmore, 26r.

General Court of Massachusetts, considers the complaint of the Church of Springfield, 363 ; decides that the Council was regular and legal, 363 ; that the magistrates had no right to interfere, 364 .

Gown AND BANDS in the pulpit, I26.

Grasmere Parish Church (England), note, $\mathbf{1} 46$.

Habeas Corpus, Writ of, insisted on, 62 ; refused, 63.

HalF-Way Covenant, 306; arose from regard for children, a survival from the Church of England, 306; "Unseparated Churches," 306 ; the grace of the Covenant, 307 ; why children were baptized, 308; small number in the Churches in "full Communion," 308 ; who are the subjects of baptism? 310 ; decision of the first Council, 309; the Synod of 1662, 309; its decision, 310 ; dissent from these views, 310; Synodists and Antisynodists, $3 \mathrm{II}$; leaders on the two sides ; call of Mr. Davenport to Boston, $31 \mathrm{I}$; the Half-Way Covenant modified, 3I2; reliance on outward forms, 313 ; the Lord's Supper a converting ordinance, 313 ; results of these doctrines, 314,336 .

Harvard College, I03, $125,132$.

HARVARD, JOHN, I24.

HaRvest Festival at Plymouth, 263 ; wild game, exercise of arms, 263; the Indians feasted, 264; not a religious festival, 264 .

Henry the Eighth, Defender of the Faith, Io; law of the Six Articles, Io; Progress of the Reformation, II.

Higginson, Francis, 88 , i22, i 58.

High Church Party in England, 42 ; reactionary party in the Church, 43; the Real Presence in the Sacrament advocated, 59. Hingiram Meeting-House, i 4 I.

Historians on the PUritans: Macaulay, 3, 43; Hallam, 3; Hume, 3 ; Carlyle, 3; Green, 14, 41, 221 ; Bancroft, 58; Campbell, $4 \mathbf{I}$. 
Historic Genealogical Society of New England, its necrology for 1893,1894 , and I $895,274,276$.

HollaND, Influence of, xxxvii, 99, I09.

HoOker's Ecclesiastical Polity, 43.

HoOKer, ThOMAS, graduated at the University at Cambridge, 125; invited to sit in the Westminster Assembly, I27; letter on the suffrage, 168; sermon, 169; his published works, 289, 299; Grace is free, 300; The Free Will, 300; depravity, 30I ;

Redemption, 301 ; free invitations, 302.

Hopkins, Samuel, izo.

Hospitality of the Puritans, 266; the two Friars, 267; the Lord's-day, 267; second company of Frenchmen, 267 ; entertained at the house of the Governor, 268; taken to the meetinghouse, 268 ; Father Gabriel Druillette, the Jesuit Missionary, 268-269; visit to Plymouth, a fish dinner on Friday, 270; visits the Apostle Eliot, 270.

House of Commons investigates abuses, 34,45 ; refuses to vote supplies without redress of abuses, 62 .

Hutchinson, Mrs. Anne, 289; banished, 290.

Hutchinson, Colonel John, of Owthorpe, 78 ; personal description, 222 ; love of art, 223; respect for woman, hatred of persecution, conjugal affection, 223; love of a military life, 224; saves the life of Cromwell, 224 ; dies in prison, 224.

Huguexots, 33 .

INDEPENDENT CHURCHES, I 58.

INDIANS, conversion of, $9 \mathrm{I}$; their marks as signatures to a deed, I93; friendly relations, I99; their independence recognized, I99.

JAMES the First, his character, $35,37,38$, 40; claims unlimited power, 40, 46; his first Parliament, 45; second Parliament, 47 ; third Parliament, 48 ; Journals of the Commons, 48 ; Book of Sports, 49, 65; his French Alliance, 50.

JOHNSON, ISAAC, I86.

JUdGMent, Day OF, I2O.

Lambeth House, Conference, 36,44 .

LA Tour visits Boston, 266-267; welcomed, saluted at his departure, 268.

Laud, Bishop of London, 59, 64; Archbishop of Canterbury, 64, 66, 74 ; suppresses Puritan Lectureships, 64 ; feoffments, 65 ; committed to the tower, 74 . 
Legislation of MASSAChusetts, I09, I I ; in respect to heretics, 203 ; tended toward democracy, 256; regulated the sale of intoxicating drinks, 256 .

Legislation of the PURitans in advance of their times, 25I ; seventeenth century laws, $25 \mathrm{I}$; more merciful than those of Virginia, 253; or New York, or England, 252 ; capital crimes, 252 ; English laws against Quakers, witchcraft, 253 ; blasphemy, penalty for, in Maryland, 253; Puritan laws against Quakers, 254; against witchcraft, 255 .

Letters From England in regard to Pynchon's book, 213 ; reply from the Elders, 213.

Letters of Governor Winthrop to his Wife, and of Margaret Winthrop to her husband, 227-232.

LetTers of Governor Winthrop to his SON, 231.

LEyden, the refuge of the Pilgrims, 56.

Libraries of the Puritans, i24.

LightiNG and warming the meeting-liouses, I 46.

LONGFELLOW, H. W., a student of New England history, 243; descendant from John Alden, 273.

Long Parliament, 7 $1,74,75$.

LORD'S-DAY began Saturday evening, I48; religious services, I 49 .

LORD'S SUPPER, mode of administering, I 54 .

Lothrop, PARSON, I 29.

LUTHER, 9.

Lycidas of MiLton, 67.

Magna Charta, a Puritan watchword, 6I.

Manners of the Early Ministers, 125-129, 130.

MARRIAGE by the Magistrate, I 65 .

Martin Mar-Prelate Tracts, 28 ; replies, 30.

Martyrs of the Separatists, 25 ; Copping, Dennis, Thacker, 25 ; Henry Barrowe, 26; John Greenwood, John Penry, 27.

MARY, restores the Mass, II ; martyrs during her reign, I2.

MASSACHUSETTS, Government of, IOO; order of nobility proposed, IOO.

Mather, Cotton, I2I, I 40, I89.

MathER, INCREASE, I 27 .

Mather, Richard, ioS, 123; salary, 132; letters to England, 213.

MAYFlOWER, The, S6, I36; departure of, 244.

Mckeen, President Joserh, $3 \$ \mathbf{z}$; preaching, 388. 
Meeting-Houses, I39; meaning of, I39; central building of the town, 140; built of logs at first, square with pointed roof, I 40 ; examples of that style, I4I ; barn meeting-house, I 42 ; sounding-board, I 42 ; benches, square pews, I 43 ; third period, I44; Christ Church, I 44 ; Old South Meeting-house, I45.

Meeting-House, in Brunswick, 373 ; its environment, 374 ; the East Meeting-house, 373,379 ; no means of heating or lighting, 380 .

Meritorious Price of our Redemption, 200 ; published i 650, copies now extant, $20 \mathrm{I}$; excitement kindled by the book, condemned to be burned, 201 ; answered by John Norton, 202 ; letters from England concerning, 203; John Cotton explains the action, 204; a nalysis of the book, 206 ; discussion of Scripture texts, versions quoted, theologians quoted, 206 ; constructive part of the book, 207; death of Christ a part of His obedience, 208.

Mid-Week Lectures, i 56.

MILK FOR BABES, by John Cotton, I 57, 286.

Millenary Petition, 36, 70; Hampton Court Conference, 37; an opportunity lost for the union of Engiish Christians, 39; the points of agreement proposed by the Puritans, $3^{6}$; King James determines to root out Puritanism, 38, 66, 95 .

Miller, Rev. JoHN, of Brunswick, notices of, 375 , note : length of his ministry, 374 ; a decided Congregationalist, $3^{S 4}$.

Milton, John, culture, love of liberty, 68; Lycidas, 67 ; love of art, 78,225 .

Ministers, The Early in New ENGLand, i i 7 ; representatives of Puritans, II 7 ; intense Protestants, I I 8 ; men of one book, II8; of education and culture, I20; original languages of the Bible, 123; libraries, I24; dignity and courtliness, 125: gown and bands, 126; dress of, I29; salaries, 132; dwellings, 135; food, I37; preaching, I52; mid-week lectures, I56; parochial work, 157 ; ordination of, $16 \mathrm{r}$.

Ministers in Maine, $3{ }^{\mathrm{I}}$; description of Rev. Samuel Eaton, 382 ; President McKeen, 382 ; use of intoxicating liquors, 383 .

Ministers limited to the PARISh, i6r.

Ministry of the Church at Plymouth, Lyford, i04: Rogers, Smith, Raynor, Charles Chauncy, I04, 106 ; John Cotton, Jr., I05.

Mistakes of The Puritans, i62; limited by their environment, 163; no public reading of the Bible without exposition, 163 ; 
services at funerals, I64; marriage by the magistrate, 165 ; days of the week by numerals, 166 ; festivals of the Christian year, 167 .

MOODY, JoSHUA, II9.

Moxon, GEorge, I93; salary of, I93.

New Exgland Theology, 330, 383 .

NEW ENGLAND TYPE of mind, 271 ; seventh generation from the founders, 272 ; modified by other types, 273 ; examples of, in our time, 273.

NEW HAMPSHIRE, 240.

New Haven, ioS.

Non-CoNformists prosecuted, 17; Dean of Christ Church in prison, I7 ; ministers in London suspencied, I7; John Foxe; preaching in private houses forbidden, 19; Non-Conformists in prisor, $17,19,25-26$.

Norton, John, graduates at Cambridge, I06, 123 ; minister of Ipswich, 123 ; salary of, 132 ; mid-week lectures, 156 ; answers the book of Mr. Pynchon, 202, 290; minister of Boston, 209; publishes The Orthodox Evangelist, 295; Decrees of God, 295; liberty of man, 296; the fall of man, 297; saving faith, 298; justification, 298 .

Officers of a Puritan Church, ío.

Old Colony Legislation, democratic, 98 ; no religious test, 99 ; severity of it, I09; Quakers at Plymouth, I00-I IO; witchcraft, I Io.

Old Colony Ministers : Ralph Partridge, John Lothrop, Henry Dunster, Samuel Newman, Charles Chauncy, Io6.

OrDer of SERvices on Sunday, I49.

Ordination of Ministers, i58, 160.

Packard, Prof. Alpheus S., 38 I.

PAlfRey, Dr. J. G., 60, 78, 85, 89, I2I, I38, 325.

Park, Prof. Edwards A., 128.

Parliamentary Leaders: Pym, 47, 48, 73, 75 ; Eliot, 47, 48, 60, $63,66,71,84 ;$ Coke, 47, 48, 75; John Hampden, 61, 70, 72, 75 ; trial of Hampden's cause, 72 ; Rex is lex, 73.

Parochial Work of the Early Ministers, I 57 ; pastoral visiting, in the eighteenth century, 384 ; methodical and faithful, $3 s_{5}$.

PARSONS, Hugh, tried for witchcraft, 196. 
Petition of Right, 6i.

Phillips, Samuel, izs.

Pilgrim Church in Plymouth, 94, 98.

Pilgrim Fathers, 49; Gainsborough-upon-Trent, 5I ; Scrooby, $5 \mathrm{I}$; spirit of the Pilgrims, 53-57; their sufferings, 52, 54, 55; their departure for Holland, 54-55; in Amsterdam, 56 ; remove to Leyden, 56 ; reasons for their going to America, 57 ; their departure, 57,84 ; poetic quality in Pilgrim history, IOI; their legislation, I09; Quakers at Plymoutl, IOy-I Io.

Pilgrim Model of a Church adopted, 94, 96.

Pilgrims, The, pioneers, 236; without domestic animals, 236; or ploughs, without milk or butter, 236 ; without nourishing food, 237; or suitable clothing, 237; compared with Jacob and his sons, $23 \mathrm{~S}$; in debt to the Company in England, 238 ; exposed to savages, 239 .

Plymouth Colony, 84; government of, 98 ; no religious tests, 99 , IOI, I02, I70.

Polity of the Early Churches, 177 ; the Cambridge Platform, I79; fellowship of the Cluurches, ISo, 285.

Political Elements in the Puritan cause, 39.

Poverty of the pioneer settrers in Maine, 380 ; the pillion, number of wheeled carriages, 380.

Preaching in Brunswick in the last century, $38_{3}$; doctrines preached, catechising, 383 .

Presbyterians in Maine, 372 ; first church in Brunswick Presbyterian, 378 ; became Congregational, 379 .

Presbyterian Ordination recognized by the Church of England, 42.

Prince, Thomas, 327.

Printing-PRESSES, not allowed, 20, 28, $3 \mathrm{I}$.

Priscilla Mullins, 243; reply to Standish, 244.

Protestant Exiles return to England, $\mathbf{I} 6$.

Protestant Reformation in England, 9; the Puritan protest

against error, 282 ; love of the Bible, 282; the Lord's-day, 283 .

Protestant Refugees in England, I6, 33 .

Province of MASSACHUSETtS, 170,338 ; provisions of its charter, union of Church and State, 339; no religious test for the Suffrage, 340 .

PUBLIC WORSHIP, 147 ; attendance required by law, I48; began at 9 o'clock, I48; called at beat of the drum, I 49; order of services, I49; prayers, 149; exposition, singing, 150; sermons, 152; afternoon services, 154 ; contributions, I 55 . 
Public Worship, and the Sacraments, in Maine, 374; how the Lord's Supper was administered, 379; baptism, 379; regular services on the Lord's-day, 380.

PuRitans in ENgland, 5, 14, 16; origin of the word, 16; Religio purissima, I6; division of the Puritans, 21 ; rapid growth of Puritanism, 30 ; political elements in the Puritan cause, 39; the defenders of liberty, $39,45,76,92$; requests from the Church of England, 36 ; their so-called bigotry, causes, 68 ; migration to New England, 69, 79; limitations of the Puritans, 76; their culture, 78, 79; John Owen, 78; Colonel John Hutchinson, 78, 222-225; their colleges, 79; their influence, So; causes of the fall of the Commonwealth, 75-76.

Puritans in New England, Non-Conformists, 84; from the upper middle classes, 90 ; political plans, 92 ; suffrage restricted by a religious test, I00; thrifty and prosperous people, 102 ; their intellectual spirit, I06; Harvard College, Cambridge Platform, I07; their legislation, I I I, 25I.

Puritans in MassachusetTs, provided with cattle and other domestic animals, 239; often destitute of nourishing food, 240 ; visited by sickness, 240 ; dependent on a wind-mill, 240 ; influence of, 273-276, 306 .

Puritan Influence in New England, 4 ; numbers who came from England, 4 ; proportion of Puritan descent, 5.

Puritan Ministers silenced, 20, 64, 67.

Puritan objections to Separatists, 94.

Puritan SCRUPles about Conformity, I 5.

Puritan Type, The, 27I ; compared with the Greek type, 27I ; Patricians of Rome, 272.

PyNCHON RECORD BOOK, 194.

Pynchon, William, Gent., I85; ancestry, i86; portrait, I87 ; education, member of the Massachusetts Company, Treasurer, ISS ; fur-trader, I88; house lot, 192; magistrate, 192, I94; controls trade with the Indians, 199; gains a large fortune, 200 ; publishes a book in 1650, 200 ; the Meritorious Price of our Redemption, 200; called to answer before the General Court, 202 ; required to retract ; causes of the excitement, politics in the case, 202; his scholarship, 206; constructive part of his book, 207; confers with the Elders, 209 ; explains his opinions before the General Court, 2 ro; meaning of his letter to the Court, 210; left out of the magistracy, 21I; placed under bonds, 2 I2 ; returns to England, 212 ; Wraysbury, literary occupations, 215; Works, 215-216; family, 217; portrait, 218; book, 290,338 . 
QUAKERS, their treatment in England, 174 ; reasons why they were not tolerated in New England, I 75 ; four of them put to death, I75; repeal of the law, I75, 254 .

ReactionaRY PARTY IN THE CHURCh, 43; advocates passive obedience, 45 ; the divine right of kings, 41, 46, 59; the high prerogatives of the king, 47; Montague, 59; Mainwaring, 59 .

REASONS FOR EXCLUDING those not of their way of thinking, 93.

ReForuation in England, 9; Luther, 9; difference between

German Reformation and the English, 9.

REFORMING SYNOD, 315.

Religion in PURitan Life, 262.

RePUblics OF GREece, 85 .

Revivals of Religion, few, 313; The Great Awakening, 314, 338 ; revivals in Maine, 385 ; in Harpswell, 386 ; in North Yarmouth, 3 S6.

RHODE ISLAND, 240.

RING IN MARRIAGE, I 5 .

Robinson, Rev. John, 52, 94, I 20.

Romanism in the Church of England, 59, 65, 66, 84, 95.

RoMANists, numbers of in England, I 5.

Royal COMmissioners, I05, 123.

RUtherFord, REv. ROBERT, 374 and note; length of pastorate, 374 .

SABbath, the PURITAN VIEW concerning, 65, 148, 268, 282-283;

Book of Sports, 65,283 .

Saleu, First Church formed, 97, I 59.

Savoy Confession, 319; an improvement on the Westminster

Confession, 320 ; adopted in Boston, I68o, 320; reaffirmed I 865,321 .

SAYBROOK PlatForM, 321; influence of, 328; in the second century, 336.

SCOTTISH WAR in $1640,73$.

Second Century in New England History, 335 ; period of trans-

ition, improved buildings, and ways of living 336: Half-way

Covenant, 336; Yale College, 336; Saybrook platform. 336;

Arminian theology, 336 .

Separatists, origin of, 21 ; Separatist Church in Norwich, 22;

Separatists in London, 24 ; persecution of, 25 ; martyrs. 25-28. Sermovs of the Puritan Ministers, 152 ; not written; length, I 53 . 
Service of Song in Massachusetts, I 50 ; in Brunswick, 379 ; number of tunes, $3^{8} \mathbf{I}$; version of psalms, $38 \mathrm{I}$.

Settlement for the Minister, I32, 340.

Seventeenth Century, 233 ; belief in witchcraft, 234 ; cruel punishments, 234; slavery, 234; simple life, reverence, dignity, 235 ; respect for philosophy and religion, 235 ; its great poets and statesmen, 236 .

Shepard, Thomas, personal history, 106, 292; pastor of the Church in Cambridge, 293; his views in theology, 293; his works, 292 note.

Ship-MONeY, 72, 74 .

Simiple Cobbler of Agawam, 258.

SingING, I 50 ; no instruments of music, I 50 ; psalter of Ainsworth, Bay Psalm Book, tunes used, I50; no choirs, 152 ; singing by note, or by rote, I $5 \mathrm{I}$; decline of church music (note), reform in methods of singing, I $5 \mathrm{I}$; church choirs, 152 ; in Maine, 379.

Skelton, Samuel, i 22 , i 58.

Social Distinctions, I43; the titles Mr. and Mrs., 256 ; Goodman and Goodwife, 257; loss of the title by a misdemeanor, 257 ; catalogues of Harvard, 257 ; the title Sir, 257.

SouNDING BOARD, I4I ; in English churches (note), I42.

SPringfield, Settlement of, I9I ; mutual agreement, I9I, I95; number of families, allotment of land, I9I ; Agawam, I9I ; agreement with the Indians, 192 ; jury, I 94 ; sets up a government, I 95 ; town-meeting, I 97; penalty for carrying fire; standard of measure; monthly training, powder not to be sold to Indians, I 97 ; wages of carpenters, I 98 ; other laborers; penalty for refusing to serve as an officer of the town; stipend paid for beating the drum for the meetings, igs.

Springfield in its Second Century, 337 ; towns in the Connecticut Valley, Association of Ministers, 337.

STAFFORD IMPEACHED, 74.

Standish, Miles, 243.

Star Chamber, 20.

SUFFRAGE Limited by a religious test, 99, I68, i69.

SUPPORT OF MiNisters, I30; voluntary contributions, I3I ; tax by authority of the Colony, I3I ; salaries of, I32; "settlement," I 32 ; not poor men, I34; qualifications, 339 ; method of selectIng a minister, 340 ; support of, 340 .

SYNOD OF I 637, 289; condemns eighty-two erroneous views, 290. SyNod of Cambridge, 16 $46,107,178,291$. 
SyNOD of 1679, 315; time and place of meeting, 315 ; questions before it, 315 ; statement of the sins of New England, 316$3 \mathrm{I} 8$; recommendations, $3 \mathrm{I} S$; seconded by the General Court, 318 ; and by the Churches, results, 319 ; adjourned meeting of the Synod, 319; Savoy Synod, and its confession, 319-320; The Boston Synod adopts its confession, 320 ; amendments, 320 ; Congregational Council of $1 S_{5}, 321$; influence of this Confession, 321,327 .

TABLE FurNiture, I37.

TAX For SUPPORT OF Churches, IoO.

TEA, not in use, 138 .

TenNyson, quoted, i I 2.

Thanksgiving Days, 167 ; days of fasting, 167 .

ThIRTY Years War, 34, 50.

Translations of the Bible, Wyclif's, 6; Tyndale's, i i ; Coverdale's, I ; King James', 37 .

UNITARIANISM IN NEW ENGLAND, origin of, 313.

Vane, Sir Henry, I85, 213.

Versions quoted in Mr. Pynchon's book, 206.

Ward, Nathaniel, 255 ; author of Body of Liberties, and the Simple Cobbler of Agawam, 258.

WAREhOUSE POINT, I99.

WATER MILL, the first, 24I.

Westminster Assembly, date of, 204; statement of its doctrines concerning Atonement, 205.

White, Rev. John, of Dorchester, England, 89.

Whitgift, Archbishop of Canterbury, is.

Willard's, Sanuel, Body of Divinity, 283 ; earliest folio in New England, 302 ; evidence for the Bible, 303 ; inspiration; election, 303; Redemption, 304; Person of Christ, Inability, 304; difference between this theology and that of Hooker, 305 .

IVILlianis, Roger, I 22, I7 I, I73; recalled, I74, 306.

Williali the Silent, $76,84$.

WiLsON, JOHN, I2I, I32.

Windille SET UP in Newtown, 240; in Boston, $24 \mathrm{I}$.

Wine and Spirituous Liquors, 139.

WiNSLOW, GOVERNOR EDWARD, 90, 96, I85.

Winthrop, ADAM, 226. 
Winthrop, Governor John, address on leaving England, 88; results from his death, 203 ; birth, 226; commemorated by statues, 226; marriage to Margaret Tyndal, 226; letters to his wife from Groton, 227; from London, 229; Southampton, 230; from the Arabella, 230; from Massachusetts, 232; writes a history, 233.

Winthrop, Margaret, 226; letters to her husband, 228-230; sails in the ship Lyon; reception by the people in Boston, 232 . WinTHROP, ROBERT C., 276.

WitchCRAFt, Pilgrim laws against, i Io; common belief in, I76; numbers put to death in Europe, 177 ; trial for witchcraft in Springfield, 196; belief in, in the seventeenth century, 234; English laws against, 253; Puritan laws, 255; reasons why the prosecutions ceased, 255 .

Wraysbury, home of Mr. Pynchon, 214, 215.

WYCLIF, JoHN, date of his birth, 6 ; translation of the Bible, 6 ; earliest English Reformer, 6; the Lollards, 7 ; persecuted, 8.

Yale College, 336; its President at the Council in Springfield, 355 .

Zealous Protestants, 282 ; appealed to the Bible, justification by faith, sanctity of the Lord's-day, 282 . 

WINTHROP, GOV: results from statues, 226; wife from $\mathrm{Grc}$ from the Ara history, 233.

WINTHROP, MAR sails in the sh Winthrop, RobF WITCHCRAFT, Pi]! numbers put Springfield, Is English laws the prosecutic WRAYSBURY, hom WYCLIF, JOHN, da earliest Englis

Yale College, 3 355 .

Zealous Protes by faith, sanc 
, 

+ 


\section{PLEASE DO NOT REMOVE}

CARDS OR SLIPS FROM THIS POCKET

\section{UNIVERSITY OF TORONTO LIBRARY}

$\mathrm{BX}$

9321

B8

1896

\section{Byington, Ezra Hoyt}

The Puritan in England

and New England 
